\author{
ZENTRUM \\ FÜR BIODIVERSITÄT UND NACHHALTIGE LANDNUTZUNG \\ SEKTION \\ BIODIVERSITÄT, ÖKOLOGIE UND NATURSCHUTZ \\ - Centre of Biodiversity ANd Sustainable LAND USE - \\ SECTION: BIOdIVERsity, Ecology ANd Nature Conservation
}

\title{
PATTERNS OF MOUNTAIN VEGETATION DYNAMICS AND THEIR RESPONSES TO ENVIRONMENTAL CHANGES IN THE SOUTH ECUADORIAN ANDES
}

\author{
Dissertation zur Erlangung des Doktorgrades der \\ Mathematisch-Naturwissenschaftlichen Fakultäten der \\ Georg-August-Universität Göttingen
}

\author{
vorgelegt von \\ M.Sc. \\ Jantz, Nele \\ aus \\ Stade
}

Göttingen, April 2013 
Referentin/Referent: Prof. Dr. Hermann Behling

Korreferentin/Korreferent: Prof. Dr. Erwin Bergmeier

Tag der mündlichen Prüfung: 30.05.2013 


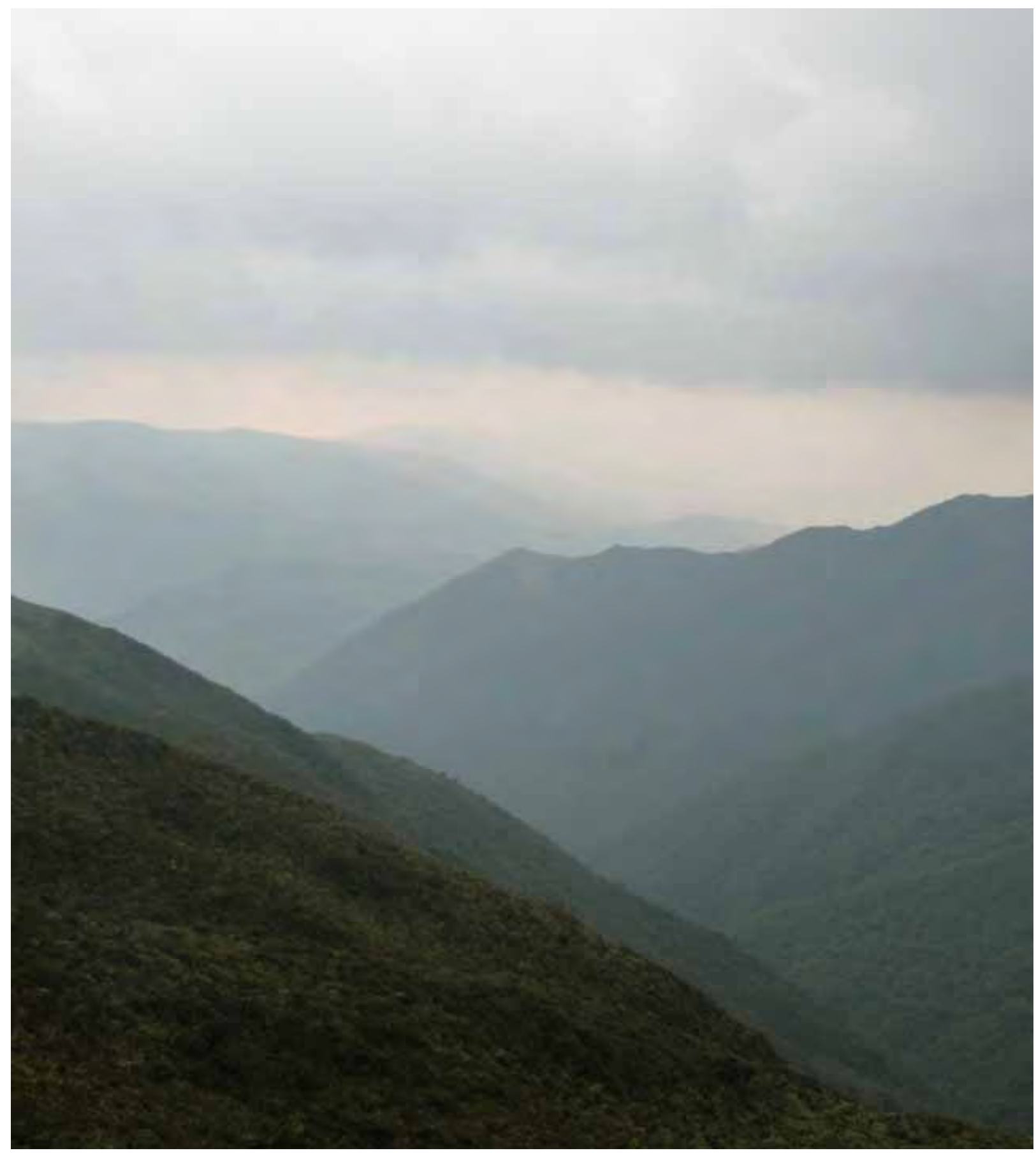

The Podocarpus National Park at Cajanuma, South Ecuador (2010) 


\section{Contents}

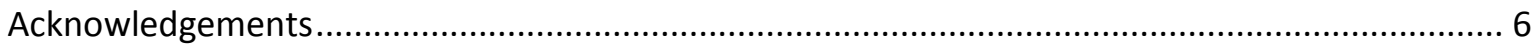

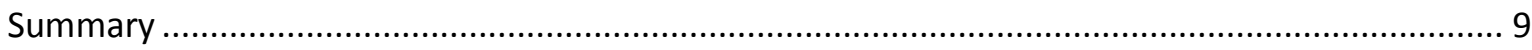

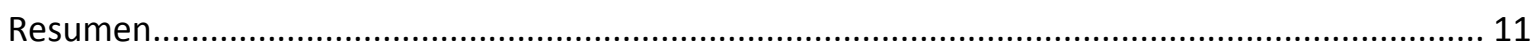

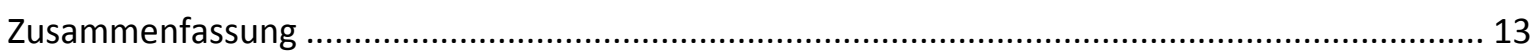

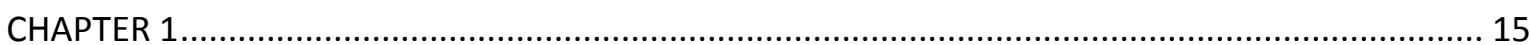

1.1 Background: Scientific Investigation of a mega-diverse ecosystem in the Andes of South

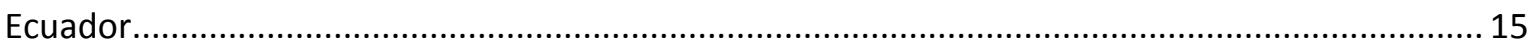

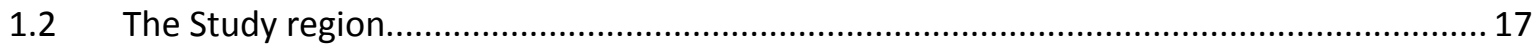

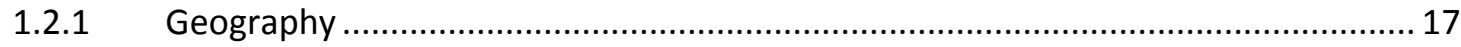

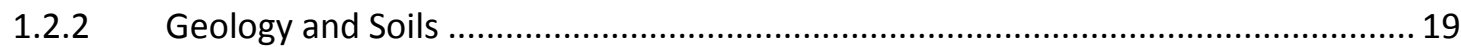

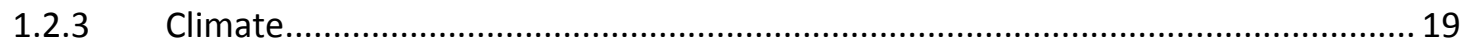

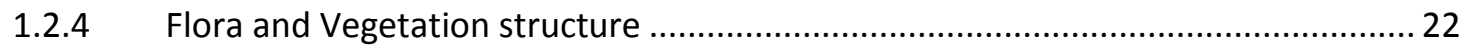

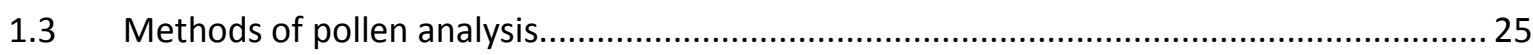

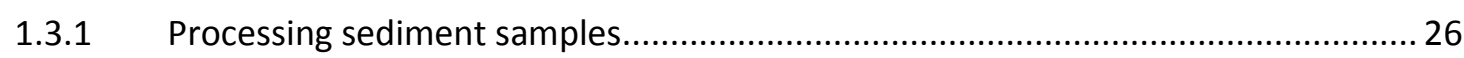

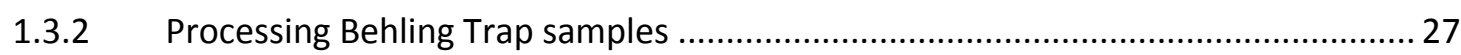

1.4 Palynological and Palaeoecological findings in the northern/central tropical Andes ......... 27

1.4.1 Vegetation and Climate history since the early Holocene ..................................... 27

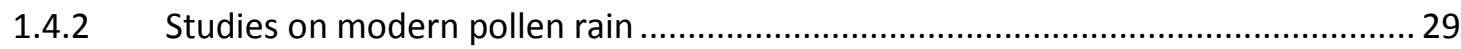

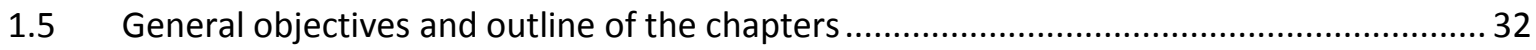

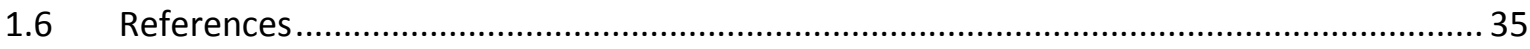

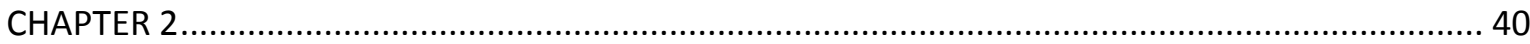

A Holocene environmental record reflecting vegetation, climate, and fire variability at the Páramo of Quimsacocha, southwestern Ecuadorian Andes ..................................................................... 40

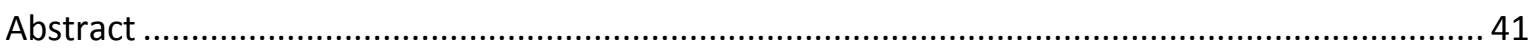

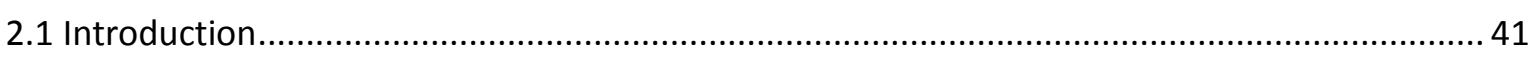

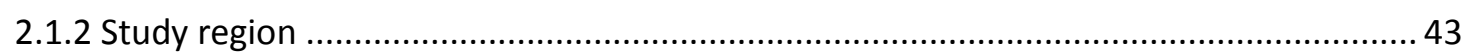

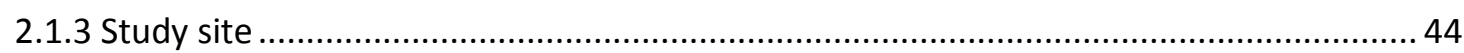

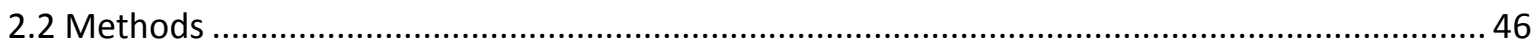

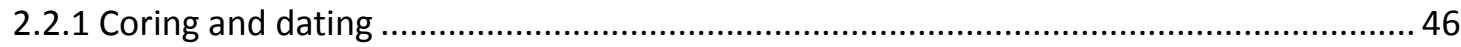

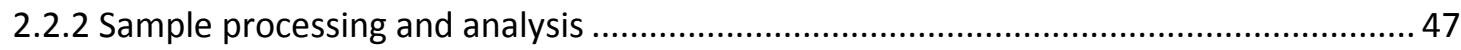

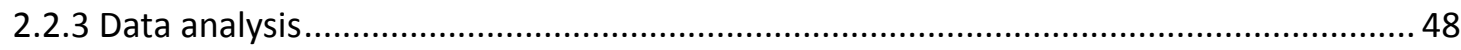

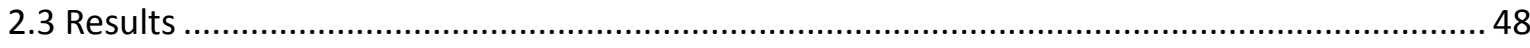

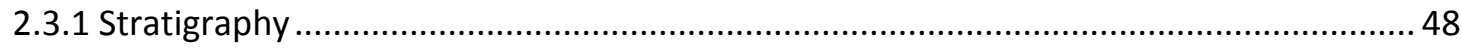

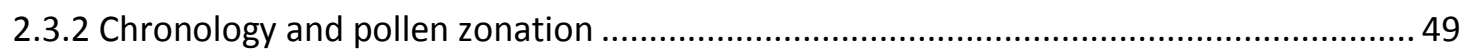

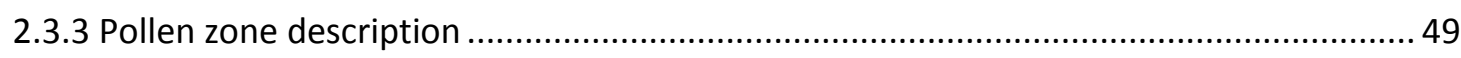

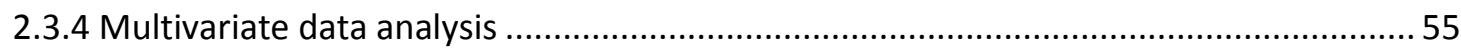

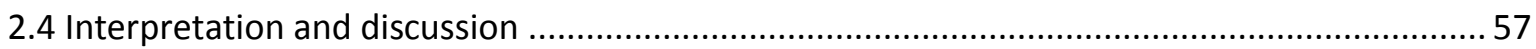




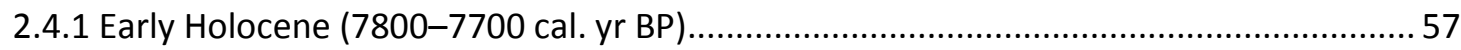

2.4.2 Early to mid-Holocene dry-event ( 7700 to 2250 cal. yr BP) .......................................... 57

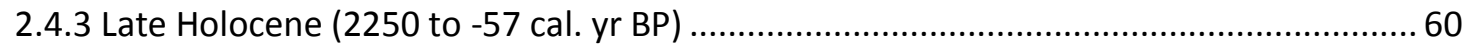

2.4.4 Fire record and early human influence in the Páramo of Quimsacocha........................ 61

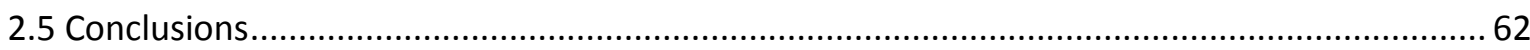

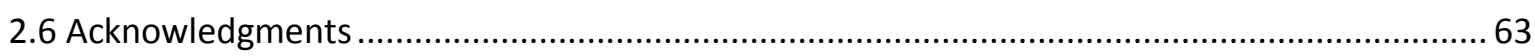

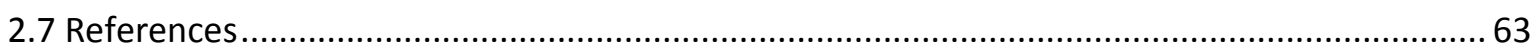

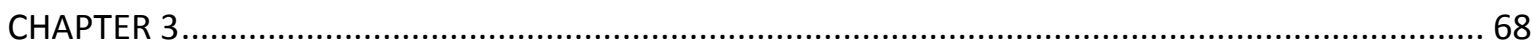

Representativeness of tree diversity in the modern pollen rain of Andean montane forests ......... 68

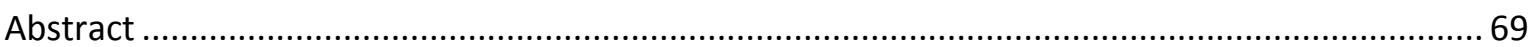

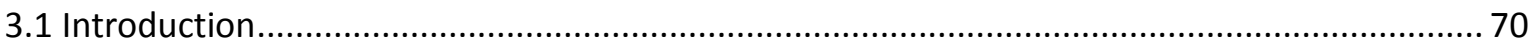

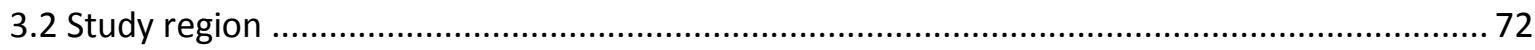

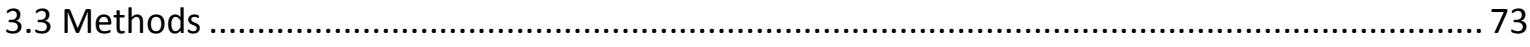

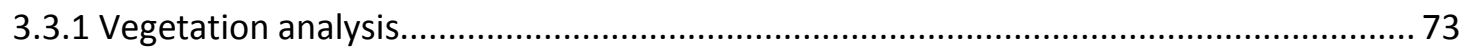

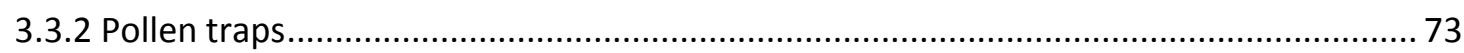

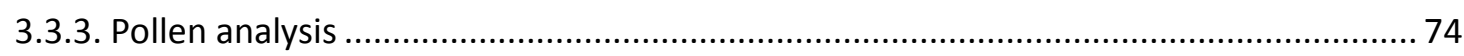

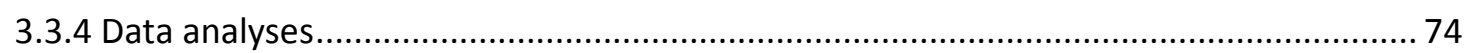

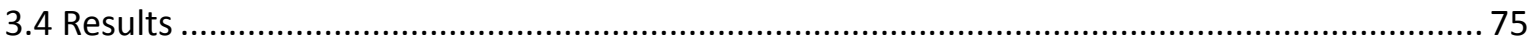

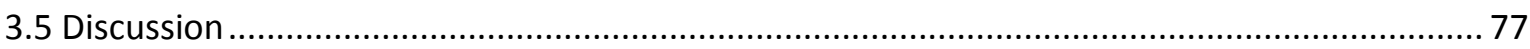

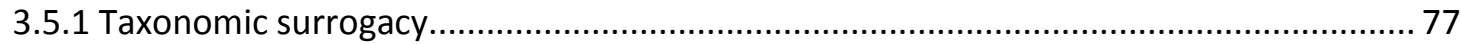

3.5.2 Diversity, long-distance transport and evenness ......................................................... 79

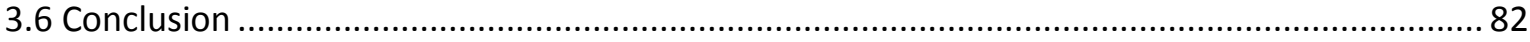

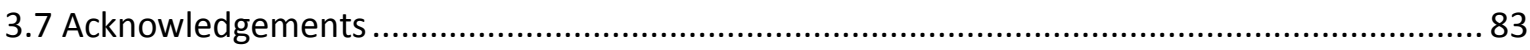

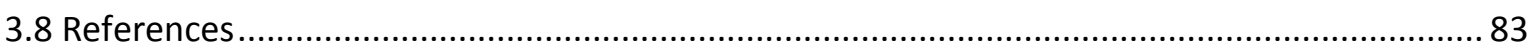

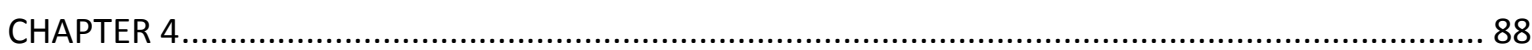

Trapping pollen in the tropics - Comparing modern pollen rain spectra of different pollen traps and surface samples across Andean vegetation zones............................................................ 88

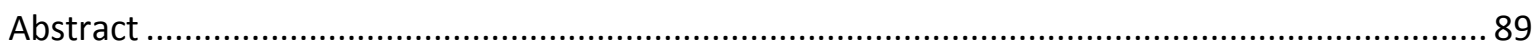

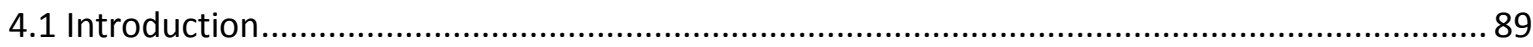

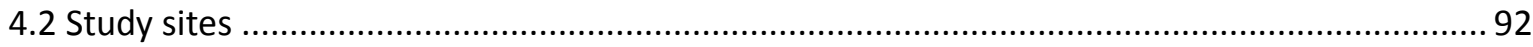

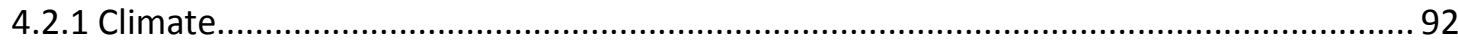

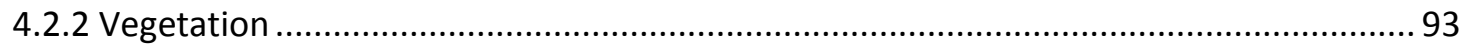

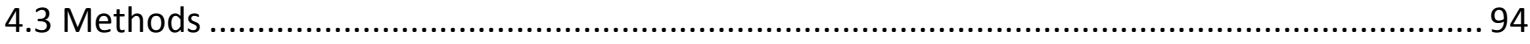

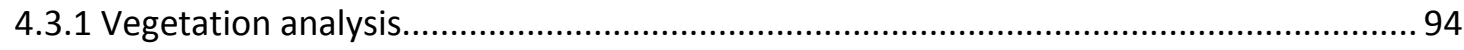

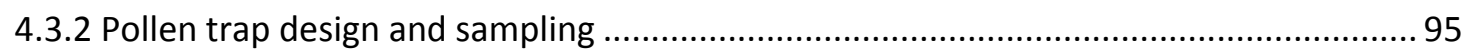

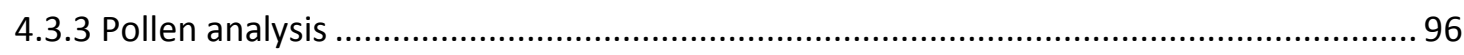

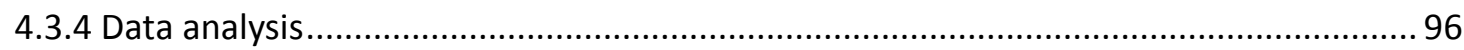




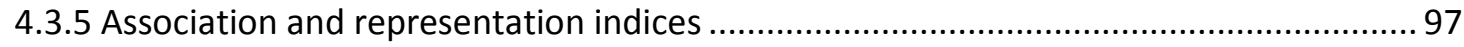

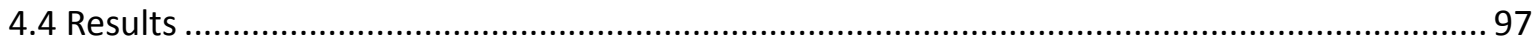

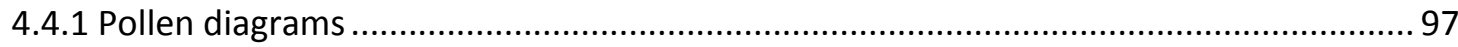

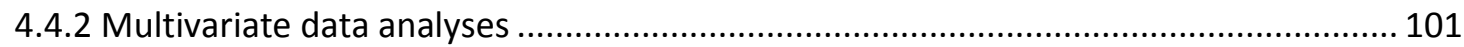

4.4.3 Indices of association and representation and diversity........................................... 105

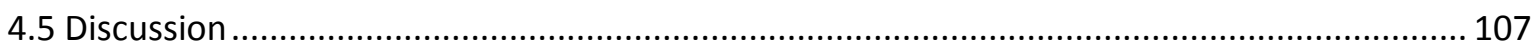

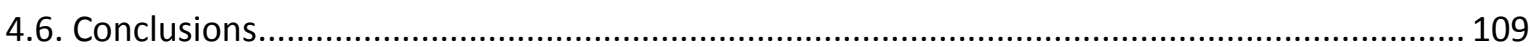

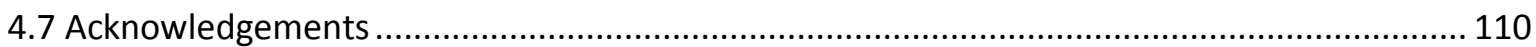

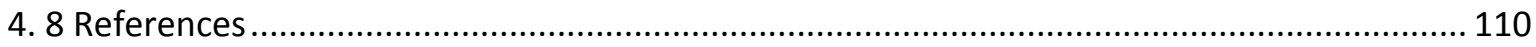

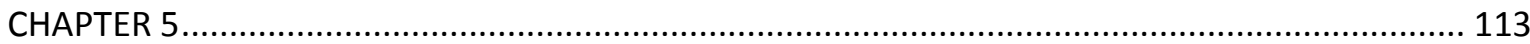

Inter-annual and local variability in pollen accumulation rates of the Andean forests of southern

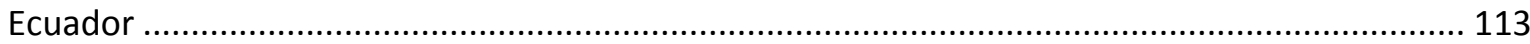

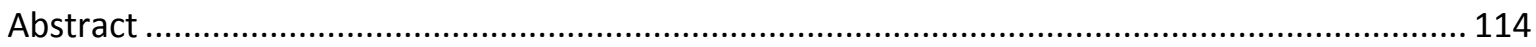

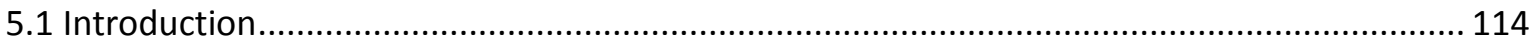

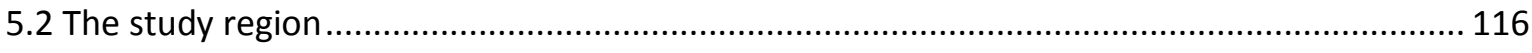

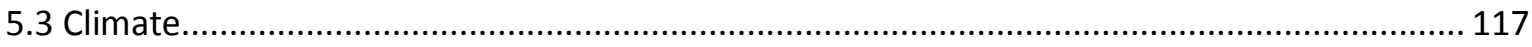

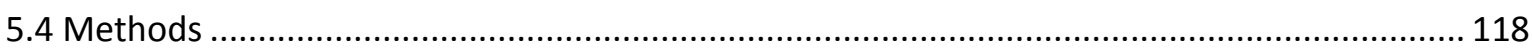

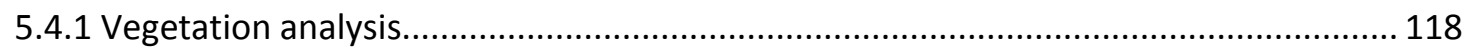

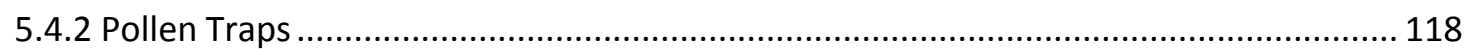

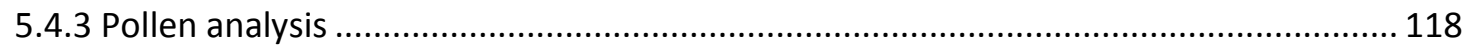

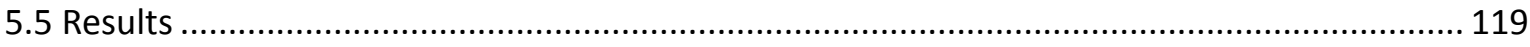

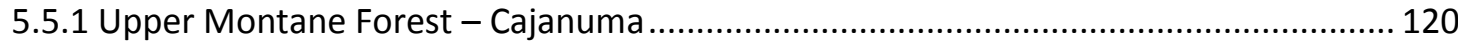

5.5.2 Lower Montane Forest - San Francisco .................................................................. 128

5.5.3 Premontane Forest - Bombuscaro ............................................................................ 133

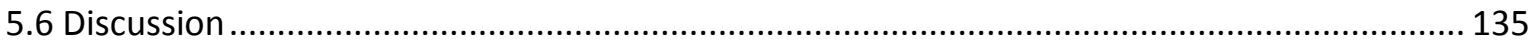

5.6.1 What are the pollen accumulation rates for characterising pollen taxa of the north-

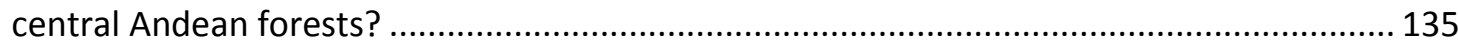

5.6.2 Do any of the characteristic pollen taxa show strong inter-annual variations in their

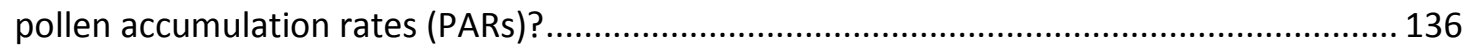

5.6.3 How strong is the influence of the pollen trap distribution on the pollen spectra?..... 138

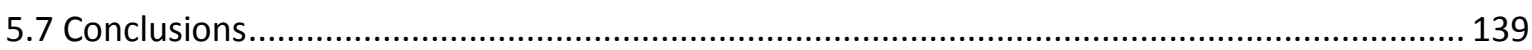

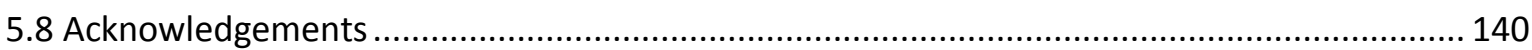

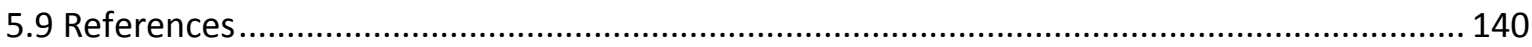

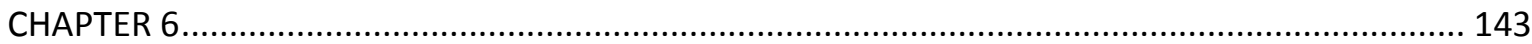

Climate Change Effects on Biodiversity and Ecosystem Functioning ......................................... 143

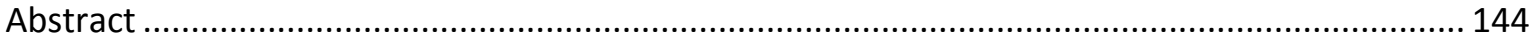

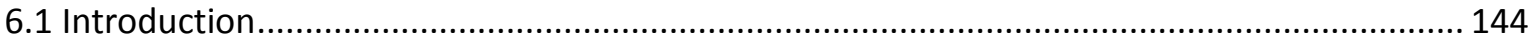

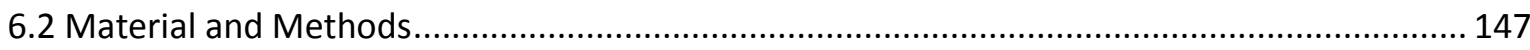


6.2.1 Palynological Studies of Past Vegetation Dynamics .................................................... 147

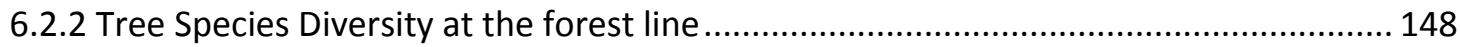

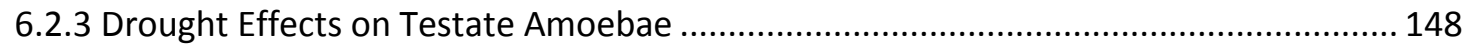

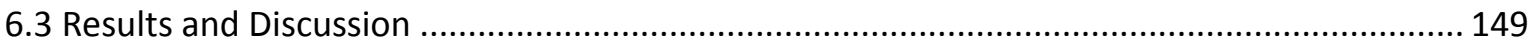

6.3.1 Palynological Studies of Past Vegetation Dynamics................................................... 149

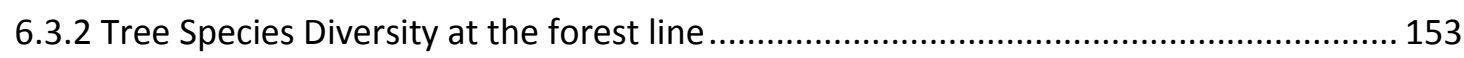

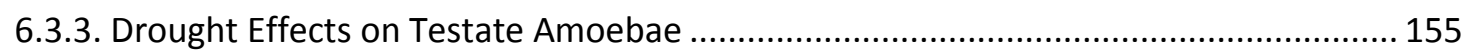

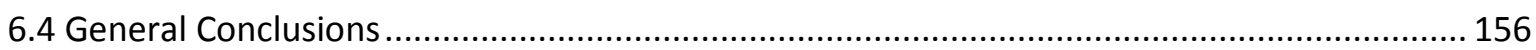

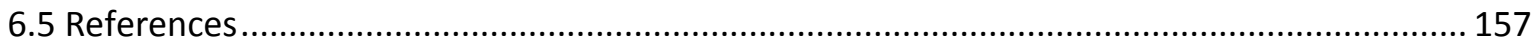

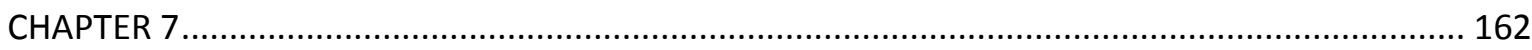

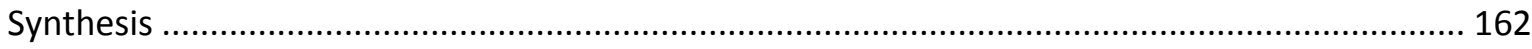

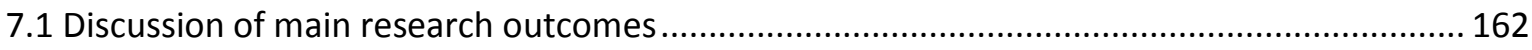

7.1.1 Holocene vegetation, climate, human impact and fire history at key sites in South Ecuador 162

7.1.2 Vegetation/modern pollen rain relationship at different vegetation types of South Ecuador 163

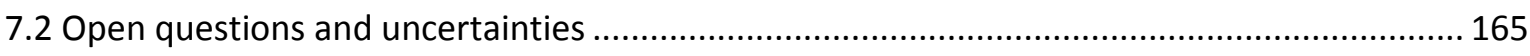

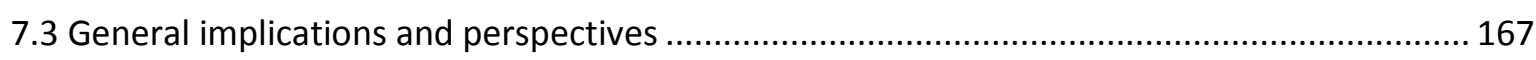

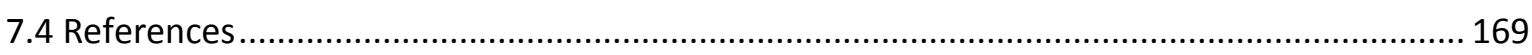

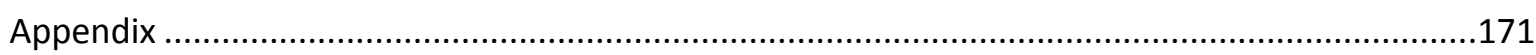

Appendix 1: Modern pollen rain studies across the Andes - An overview ................................... 172

Appendix 2: Representation of taxa in Andean modern pollen rain studies............................... 176

Appendix 3: List of all Matrix-plots with topographic information............................................... 183

Appendix 4: Identified pollen and spores of the Tres Lagunas records and the modern pollen rain studies from the Podocarpus National Park region - complete list and photos ........................... 185

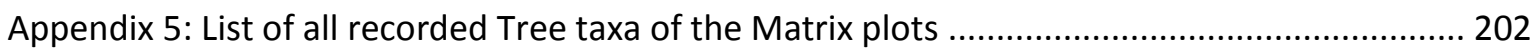

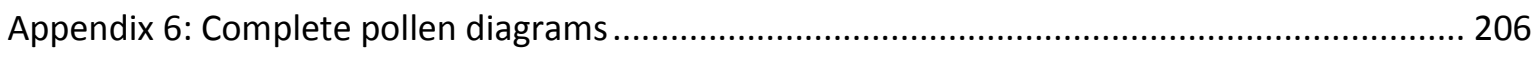

Appendix 6.1: Tres Lagunas sediment core .................................................................... 207

Appendix 6.2: Modern pollen rain Bombuscaro 2009-2012 ........................................... 214

Appendix 6.3: Modern pollen rain San Francisco 2009-2012 …....................................... 219

Appendix 6.4: Modern pollen rain Cajanuma 2009-2012 …............................................ 225

Appendix 6.5: Modern pollen rain from different trap types 2010-2011 ......................... 231 


\section{Acknowledgements}

Many people have directly or indirectly contributed to my work and non-work life during the past three years, which let me enjoy my time as a scientist and non-scientific person and helped me to create this thesis as it is.

My special thanks go to my first supervisor, Professor Hermann Behling, who helped me to discover the fascinating worlds of palynology and palaeoecology. He encouraged me, supported me, challenged me and at the same time gave me the freedom I needed to develop new ideas, concepts and strategies for my scientific work.

I also would like to thank my second and third supervisors, Professor Erwin Bergmeier and PD. Michael Kessler. They acknowledged my work, helped me to keep a more general view on the topic in mind and supported me with their broad knowledge on ecological topics.

I would like to thank the DFG for the funding of the research unit 816 "Biodiversity and Sustainable Management of a Megadiverse Ecosystem in South Ecuador" and of our subproject D1 "Analysis and synthesis of palaeoecological data revealing patterns of mountain vegetation and plant diversity dynamics and its response to climate, fire, land use changes in biodiversity hotspots through space and time".

I am very grateful to Dr. Jürgen Homeier, who apart from his data, shared ideas and methods with me and introduced me with great enthusiasm and patience into the world of living plants of many sites all over Ecuador. I also appreciate the good collaboration with Susana León-Yánez from the Pontificia Universidad Católica del Ecuador (PUCE), who shared data and thoughts about Páramo vegetation with me and kindly provided a working space during my stay in Quito. In this context, I also thank Alejandra Moscoso who was a great help in obtaining and understanding data and keeping enthusiasm about vegetation even in the harshest climatic conditions in the Páramos of Ecuador.

I also wish to thank many people who accompanied and helped me with great enthusiasm during field work, especially Stéphany and Andrea Villota, Jaime Peña, Annemarie Körfgen, Andrés Gerique, Michael Burstert, Corinna Brunschön and Fernando Rodríguez. 
The field work would not have been possible without the team of the Estación Científica San Francisco, with the local managers Felix Matt and Jörg Zeilinger, the drivers Abraham, Tati, Roberth and Daniél, the kitchen and housekeeping-team with, among others, Doña Maria, Rocío, Maria, Karina, Susy, José and Alberto as well as the guards and also many fellow researchers, especially Agnes, Amanda, André, Angelica, Anke, Brenner, Claudia, Daniel, Fabian, Florian(x2), Franca, Giulia, Isa, Julia, Kristin, Philipp, Roman, and Sandro. They all helped to make my stay at the research station not only a comfortable, but also great, inspiring and unforgettable experience and even rescued me probably more than once!

I wish to especially thank Andrea Villota and Fernando Rodríguez with their families, who supported me at all times during my stays in Ecuador and shared not only their house but also let me be part of their families and introduced me into the Ecuadorian culture, language and Salsa skills and became great friends for life!

Thanks also to the entire staff of the Department of Palynology and Climate Dynamics. It was a great time, I appreciated the scientific and social company of each one of you. In this context I especially want to thank Inke Achterberg, Siria Biagioni, Jörg Christiansen, Sonia Fontana, Thomas Giesecke, Ulla Grothmann, Barbara Hermanowski, Vivian Jeske-Pieruschka, Alejandra Leal, Petra Lembcke, Isabelle Matthias, Waheed Murad, Anastasia Poliakova, Jackson Rodrigues, Lisa Schüler, Lyudmila Shumilovskikh and Liang-Chi Wang, who always maintained the good spirit, gave room for scientific enthusiasm and were nice company at work-related and non-work related social events.

Thomas Giesecke is thanked for fruitful scientific discussions and help with exploring palynological datasets that encouraged me to develop new ideas and enriched my scientific work.

I especially thank Vivian Jeske-Pieruschka and Jackson Rodrigues for sharing the office, many thoughts and Brazilian culture with me.

I am also grateful for the big help of the student assistants Jan Hoeber, Jenna Kulp, Sabine Stolzenberg, and Martin Zweigert.

Apart from my scientific work I would especially like to thank Charlotte, Lisa, Ricarda and Simone for being there for me at all times and for being the best friends I could wish for. 
Many thanks also to Alireza, Basto, Biene, Carole, Christian, Daiana, Daysi, Diego, Doreen, Eva, Fabio, Federico, Florian, Georg, Giovanni, Hugo, Jan, Joanna, Judith, Jule(x2), Katrin, Laura, Linda, Maggi, Marcel, Mareike, Maren, Marie-Louise, Marion, Martin, Micha, Mona, Nina, Oliver, Philipp, Rico, Thorben, Thorsten, Tin, Tinoush, and Wiebke, who all enriched my life with their friendship and company during the past years and helped me to gather strength and discover and enjoy life in many different ways.

Lastly, I would like to thank my family - my parents Eckehard and Susanne, my sister Beke, my brothers Michael and Matthias, my grandmother Eva-Maria and Stefan, Eva, Jakob and Konrad. They support and encourage me at all times of my life, each one in his/her own way, and make me feel loved and at home, no matter how far I may be in terms of space.

Thank you! 


\section{Summary}

The South Ecuadorian Andes harbour an outstandingly high species-richness. Many different environmental factors influence one another in a most limited space and create unique and complex ecosystems. This area is highly endangered because of growing human impact through the intensification of land-use and global change. Only little is known about palaeoecological history and landscape dynamics of this area. The information about why and how ecosystems changed in the past is crucial for the development of innovative strategies for conservation and future climate predictions. In this study, we present palynological analyses carried out in the southern Ecuadorian Andes region that help to shed light on patterns and processes in present and past ecosystems.

A palaeoecological study of the Quimsacocha volcanic basin on the eastern ridge of the western Andean Cordillera reveals climate, vegetation and fire regime changes since the early Holocene period. The mid-Holocene was a period of severe environmental change due to a drier and supposedly warmer climate in this area. During the late Holocene, several warm and cool phases are indicated in the record. Fire was present in the area since the early Holocene and may be a first sign of human impact. Combined multivariate analysis with other cores in the south Ecuadorian Andes revealed partly contrasting developments, which are supposedly due to the environmental heterogeneity of the different sites.

Furthermore, a three year study of the modern pollen rain - vegetation relationship was carried out in the Podocarpus National Park region, in order to understand the pollen dispersal patterns of the different vegetation types of premontane forest, lower montane forest, upper montane forest and páramo to create a better basis for interpretation of fossil pollen data. A comparison of abundance and presence-absence data at family level for pollen and vegetation showed that diversity, distribution and abundance patterns correspond well to one another in both datasets. However, varying amounts of long-distance transported pollen, uneven pollen productivity of different taxa and heterogeneous wind systems impact the patterns. Analyses of pollen accumulation rates indicated low inter-annual but high spatial variation in the pollen data. The assessment of two different pollen trap types frequently used in tropical palynological studies, the modified Oldfield trap and the Behling trap, in comparison with surface soil samples and a reference trap, showed that in soil samples, taxa with a fragile exine are represented to a lesser extent than in the traps. Furthermore, it indicated that whereas in the forest, all trap types provide similar results, the Behling trap should be preferred in the páramo, as it better withstands 
high radiation and dry periods. All analyses add to a precise and comprehensive understanding of vegetation dynamics of the tropical Andes hotspot in space and time. 


\section{Resumen}

El sur de los Andes Ecuatorianos alberga una extraordinaria riqueza de especies. Muchos factores ambientales diferentes influyen entre sí en un espacio muy limitado y crean ecosistemas únicos y complejos. Sin embargo, esta área está altamente en peligro debido al creciente impacto humano a través de la intensificación del uso de la tierra y cambio global. Sólo poco se sabe acerca de la historia paleoecológica y dinámica del paisaje de esta zona. Sin embargo, la información acerca del por qué y cómo los ecosistemas han cambiado en el pasado es crucial para el desarrollo de estrategias innovadoras para la conservación y futuras predicciones del clima. En este estudio, presentamos los análisis palinológicos realizados en la región sur de los Andes Ecuatorianos, que ayudan aclarar los patrones y procesos de los ecosistemas presentes y pasados.

El estudio paleoecológico de la cuenca volcánica Quimsacocha en la cresta oriental de la Cordillera Occidental revela cambios del clima, la vegetación y del régimen del fuego desde el período del Holoceno temprano. El Holoceno medio fue un período de severos cambios ambientales debido a un clima más seco y supuestamente más cálido en esta área. Durante el Holoceno tardío, varias fases cálidas y frías se indican en el registro. El fuego estuvo presente en la zona desde el Holoceno temprano y puede ser el primer signo del impacto humano. El análisis multivariado combinado con otros núcleos de sedimentos en el sur de los Andes Ecuatorianos reveló acontecimientos, en parte, contrastantes, los cuales supuestamente son debido a la heterogeneidad ambiental de los diferentes sitios.

Por otra parte, un estudio de tres años entre la relación lluvia de polen actual - vegetación se llevó a cabo en la región del Parque Nacional Podocarpus, con el fin de comprender los patrones de dispersión de polen de los diferentes tipos de vegetación del bosque premontano, bosque montano bajo, bosque montano alto y páramo para crear una base más sólida para la interpretación de los datos de polen fósil. Una comparación entre la abundancia y los datos de presencia-ausencia a nivel de familia para el polen y la vegetación mostró que los patrones de diversidad, distribución y abundancia tienen una buena correspondencia el uno con el otro en ambos conjuntos de datos. Sin embargo, cantidades variables del polen transportado de larga distancia, la productividad desigual de polen de los diferentes taxones y los sistemas heterogéneos del viento impactan los patrones. Los análisis de las tasas de acumulación de polen indican poca variación interanual pero una alta variación espacial en los datos de polen. La evaluación de los dos diferentes tipos de trampa de polen utilizados con frecuencia en estudios palinológicos tropicales, la trampa Oldfield modificada y la trampa Behling, en comparación con muestras de suelo superficial y una trampa de referencia, mostró que en las muestras de suelo, 
los taxones con una exina frágil se representan en menor medida que en las trampas. Además, señaló que mientras que en el bosque, todos los tipos de trampas proporcionan resultados similares, la trampa Behling se debe preferir en el páramo, ya que resiste mejor a la alta radiación y periodos de sequía.

Todos los análisis amplían el conocimiento preciso y completo de la dinámica de la vegetación de los Andes Tropicales en el espacio y el tiempo. 


\section{Zusammenfassung}

Die südecuadorianischen Anden beherbergen eine außergewöhnlich hohe Artenvielfalt. Viele verschiedene Umweltfaktoren beeinflussen sich auf sehr limitiertem Raum und erschaffen so einzigartige und komplexe Ökosysteme. Dieses Gebiet ist jedoch auf Grund des zunehmenden menschlichen Einflusses durch die fortschreitende Intensivierung der Landnutzung und des globalen Wandels hochgefährdet. Wir wissen nur wenig über die paläoökologische Geschichte und Landschaftsdynamik dieses Gebiets. Die Information über das warum und wie einer Veränderung von Ökosystemen ist unerlässlich für die Entwicklung innovativer Strategien für Naturschutz und im Hinblick auf zukünftige Klimaveränderungen.

In der vorliegenden Studie werden palynologische Analysen aus den südecuadorianischen Anden vorgestellt, die dazu beitragen, Muster und Prozesse heutiger und vergangener Ökosysteme zu beleuchten.

Eine paläoökologische Studie des Quimsacocha-Vulkanbeckens auf der östlichen Erhebung der Westkordillere der südecuadorianischen Anden deckt Klima-, Vegetations- und Brandregimeveränderungen in dieser Region seit dem frühen Holozän auf. Das mittlere Holozän war eine Zeit starker Umweltveränderungen, verursacht durch ein trockenes und wohl wärmeres Klima. Während des späten Holozäns wechselten sich mehrere Kalt-und Warmphasen ab. Brände können seit dem frühen Holozän im Gebiet verzeichnet werden. Sie könnten ein erstes Zeichen menschlichen Einflusses darstellen. Mit anderen paläoökologischen Aufzeichnungen aus den südecuadorianischen Anden verglichene multivariate Analysen decken teilweise konstrastierende Entwicklungen an den verschieden Standorten auf, die vermutlich durch die Heterogenität der Umweltfaktoren zu erklären sind.

Weiterhin wurden Studien zum Verhältnis von heutigem Pollenregen mit der Vegetation in der Podocarpus Nationalpark-Region durchgeführt, um die Pollenverbreitungsmuster innerhalb der verschiedenen Vegetationstypen, prämontaner Wald, unterer Bergwald, oberer Bergwald und Páramo, zu verstehen und damit eine bessere Grundlage zur Interpretation fossiler Pollendaten zu schaffen. Ein Vergleich von Abundanz und An-/Abwesenheitsdaten von Familien als taxonomischer Einheit für Pollen- und Vegetation zeigt, dass Diversität, Verbreitung und Häufigkeiten beider Datensätze gut miteinander in Verbindung gebracht werden können. Dennoch werden die Muster durch variierende Anteile von durch Ferntransport eingetragenen Pollenkörnern sowie durch unterschiedliche Pollenproduktivität verschiedener Taxa und heterogene Windsysteme beeinflusst. Analysen der Pollenakkumulationsraten, die über drei Jahre 
erfasst wurden, lassen auf eine geringe inter-annuelle aber hohe räumliche Variation in den Daten schließen.

Eine vergleichende Untersuchung zweier häufig für tropische palynologische Studien genutzter Pollenfallentypen, der Behlingfalle und der modifizierten Oldfieldfalle, im Zusammenhang mit Boden-Oberflächenproben und einer zum Vergleich herangezogenen Referenzfalle konnte zeigen, dass Taxa mit einer fragilen Exine in den Bodenproben weniger stark repräsentiert sind als in den Fallen. Während beide Fallentypen im Wald ähnliche Ergebnisse liefern, ist die Behlingfalle im Páramo vorzuziehen, da sie unter hoher Strahlung und Trockenheit besser standhält.

Alle Analysen tragen zu einem präzisen und umfassenden Verständnis der Vegetationsdynamik des Biodiversitäts-Hotspots der tropischen Anden in Raum und Zeit bei. 


\section{CHAPTER 1}

\section{Introduction}

\subsection{Background: Scientific Investigation of a mega-diverse ecosystem in the Andes of South Ecuador}

The tropical Andes are considered to be one of the world's regions with highest species diversity. Over 5,000 species of vascular plants are found per 10,000 km² (Mutke and Barthlott 2005, Barthlott et al. 2007, Kreft and Jetz 2007, Mutke et al. 2011, see Fig. 1). They are also one of the five most important biodiversity hot-spots in the world, defined by high species endemism, a very

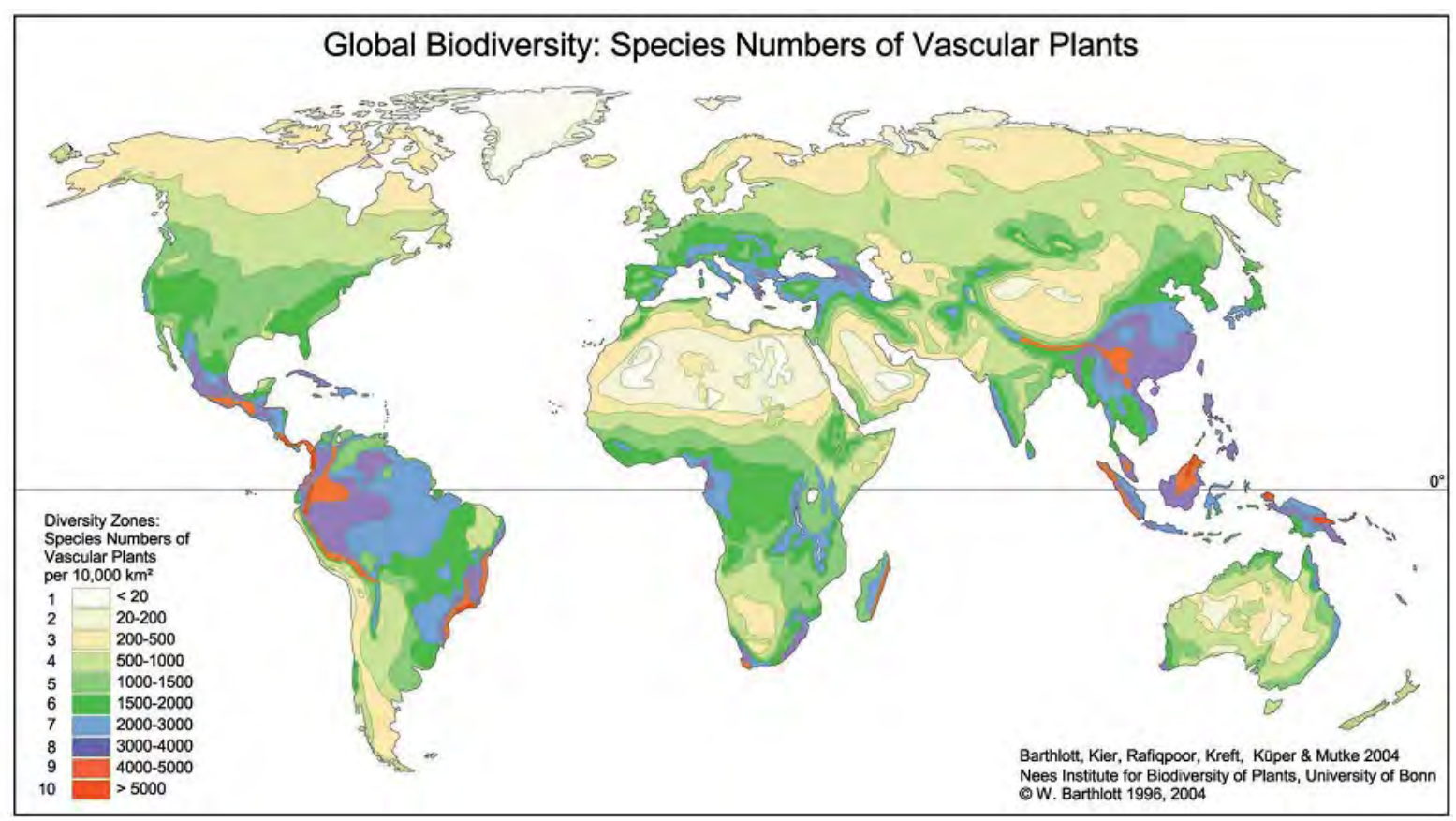

Figure 1 World map of species richness of vascular plants. (Source: Mutke and Barthlott 2005).

high species/area ratio and a high degree of threat (Myers et al., 2000). They contain more than 20,000 plant and 1,570 vertebrate species in an area of about $314,500 \mathrm{~km}^{2}$ remaining primary vegetation which once had an original extent of 1,258,000 $\mathrm{km}^{2}$ (Myers et al. 2000).

The south Ecuadorian Andes harbour a wide variety of vegetation types, including premontane forest, lower montane forest, upper montane forest and páramo above the tree line. The natural ecosystems of the Ecuadorian Andes are not only known for their high diversity and endemism 
(Balslev and Luteyn 1992, Jørgensen and León-Yánez 1999, Luteyn 1999), but also for the provision of important ecosystem services, e.g. regulation of hydrology and protection from erosion.

Investigations revealed that Ecuador has the highest deforestation rate in South America, with a loss of 198,000 ha/year during 2000-2005, which corresponds to an annual increase in forest loss of $1.7 \%$ per year for that time (FAO 2006). Fire, cultivation and overgrazing lead to serious environmental problems in Andean ecosystems. These include increase in soil erosion, decrease in water retention capacity and biodiversity loss (Podwojewski et al. 2006).

For the development of effective and innovative conservation and land use management strategies, a broad base of knowledge about ecosystems response to climate change and disturbance is crucial. Palynology, as a palaeoecological research method, is an excellent tool to reveal past vegetation and biodiversity changes and the reaction of an ecosystem to environmental stress (Willis et al. 2007).

For this reason, Ecuadorian as well as German palynologists funded by the Deutsche Forschungsgemeinschaft (DFG) have been working in the Andes of South Ecuador since 2000, first within the RU 402 (“Functionality in a Tropical Mountain Rainforest: Diversity, Dynamic Processes and Utilization Potentials under Ecosystem Perspectives") and since 2007 within the RU 816 ("Biodiversity and Sustainable Management of a Megadiverse Mountain Ecosystem in South Ecuador", http://www.bergregenwald.de).

Since 2010, the group of palynologists from the Department of Palynology and Climate Dynamics of the Georg-August University Göttingen was organized in the subproject "Analysis and synthesis of palaeoecological data revealing patterns of mountain vegetation and plant diversity dynamics and its response to climate, fire, land use changes in biodiversity hotspots through space and time".

The group's main research area was concentrated in the Podocarpus National Park region of South Ecuador (Fig. 1) and the ca. $11.2 \mathrm{~km}^{2}$ big core area of the Reserva Biológica San Francisco at its border between the Ecuadorian provinces of Loja and Zamora-Chinchipe. This region covers a wide range of ecosystems, ranging from premontane forest (Bombuscaro, ca. $1000 \mathrm{~m}$ a.s.l.), to lower montane forest (San Francisco, ca. 2000 m a.s.l.), upper montane forest (Cajanuma, ca. $3000 \mathrm{~m}$ a.s.l.) and páramo (Cajanuma, ca. $3500 \mathrm{~m}$ a.s.l.) and is known for its high rates of biodiversity and endemism (Richter et al. 2009). It thus gives an excellent core region for extensive and detailed studies of changes in past vegetation and climate development.

Throughout the years, many studies have been carried out on palaeoenvironmental archives, giving a good overview of local and regional past environmental changes during late Pleistocene 
and Holocene times (see subsection 1.3). Therefore, the goals of this thesis were not only the analysis of sediments that could extend the regional view on vegetation and climate history, but also to make a reliable view about past vegetation development as well as a more quantitative view on pollen distribution patterns and estimated species richness by the means of pollen analysis possible. To complete this task, comprehensive knowledge about the present modern pollen rain - vegetation relationship throughout the different vegetation types is indispensable which is why a major part of the thesis is dedicated to this topic.

\subsection{The Study region}

\subsubsection{Geography}

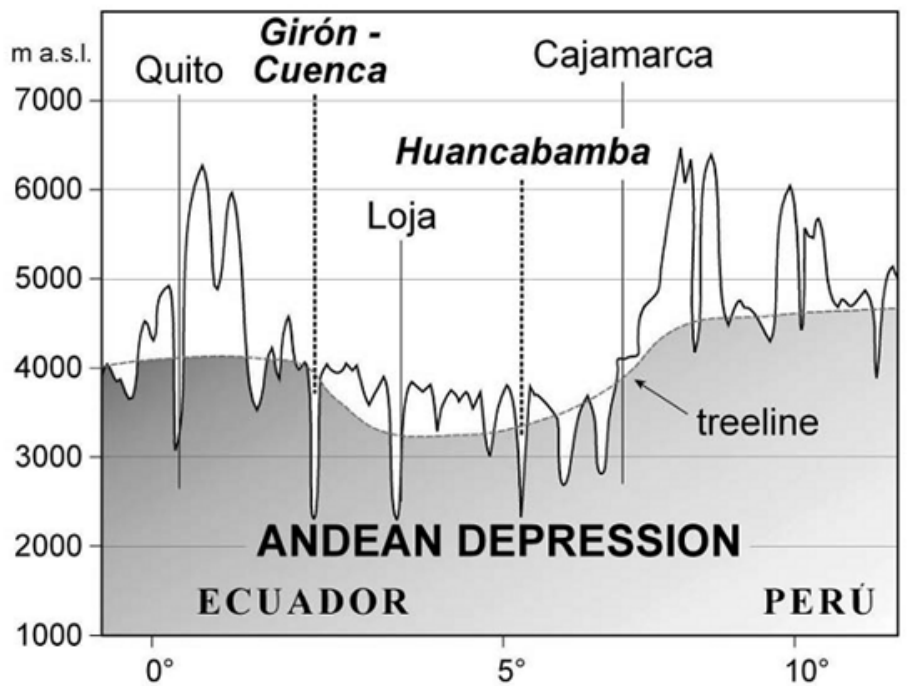

Figure 2 Position of the Andean Depression (Source: Richter et al., 2009)
The study sites are located in the Andes of South Ecuador (Fig. 2). Both regions, Quimsacocha and the Podocarpus National Park, are part of the Andean depression, which stretches from Cuenca-Giron in Ecuador to Huancabamba in northern Peru and divides the northern from the central Andes (Weigend 2002, Fig. 2). In this region, mountains barely reach $4000 \mathrm{~m}$ height and the treeline is

generally lower than in other parts of the tropical Andes, reaching altitudes of 3000-3400 $\mathrm{m}$ a.s.l. (Richter et al. 2009). Active volcanoes are absent in this region.

\section{a. Quimsacocha}

The Quimsacocha volcanic basin is located on the eastern ridge of the western Andean Cordillera in Azuay province, South Ecuador. It is a shallow old volcanic basin of ca. $8 \mathrm{~km}^{2}$ diameter at an altitude of $3780 \mathrm{~m}$ a.s.l. (Fig. $3 \mathrm{~b}$ and c). 


\section{b. Podocarpus National Park and Reserva Biológica San Francisco}

The Podocarpus National Park belongs to the provinces of Loja and Zamora-Chinchipe and is situated in the south-east of Ecuador. It covers an area of $1462 \mathrm{~km}^{2}$ and an altitudinal range from 900 to 3600 m a.s.l.. The Reserva Biológica San Francisco is located close to the province border of
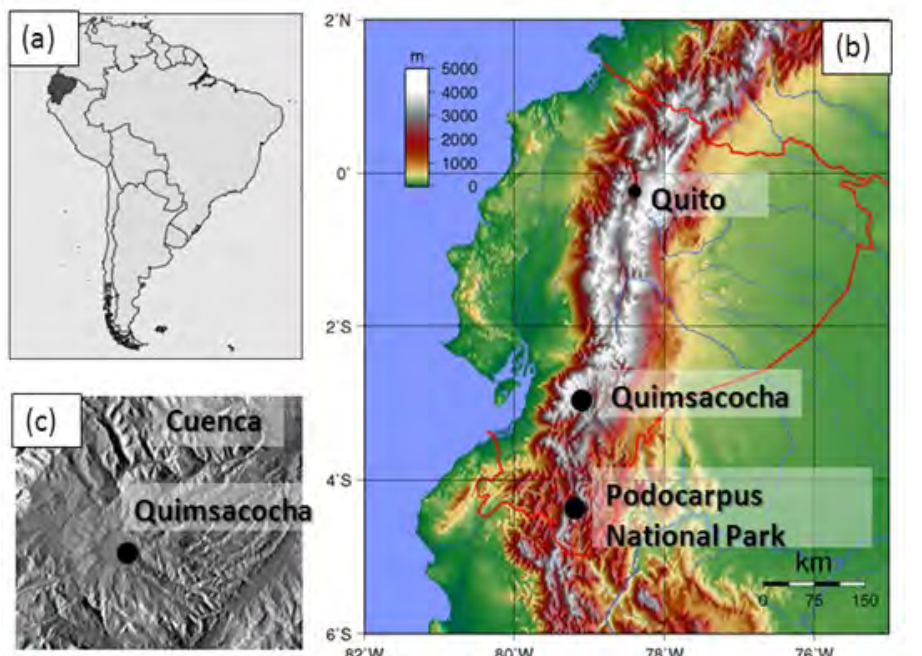

Loja and Zamora-Chinchipe, at outer fringe of the Podocarpus National Park, covering the area around the Río San Francisco basin. Three study sites were analysed in this region (Fig. $3 \mathrm{~d}$ ):

i. Bombuscaro, which is located in the Podocarpus National Park close to the province capital Zamora at UTM $17 \mathrm{M}$ ca. 72500 and 9544900 at an altitude of ca. $1000 \mathrm{~m}$ a.s.l.. This area is covered by premontane forest (see supplementary of manuscript II, chapter 3).

ii. The San Francisco area, located in the Reserva Biológica San Francisco around the San Francisco research station ("Estación Scientífica San Francisco", ECSF), which is situated at UTM 17M ca. 714000 and 9560300 at

Figure 3 (a) map of Ecuador in South America (b) location of the study regions (c) Location of the Quimsacocha volcanic basin in relation to Cuenca (d) Location of the study sites within the Podocarpus National Park. (Sources: Wikipedia.org (Fig. 2 a, b), planiglobe.com (Fig. 2 c), J. Homeier (Fig. 2 d). an altitude of around $2000 \mathrm{~m}$ a.s.I. (see supplementary of manuscript II, chapter 3).

iii. Cajanuma, located at the north-western fringe of the Podocarpus National Park at UTM $17 \mathrm{M}$ coordinates ca. 70200 and 9545500 . The sites investigated were located at an altitude of ca. $3000 \mathrm{~m}$ a.s.I. (see supplementary of manuscript II, chapter 3). 


\subsubsection{Geology and Soils}

\section{a. Quimsacocha}

The Quimsacocha basin is geologically influenced by its former volcanic activity. At the Tres Lagunas site, ashflow tuffs, rhylithic to andesitic volcanic breccias, pyroclastic flows and imbrignites are the dominant lithologies of the Tarqui-formation, which was formed during the late Miocene to Plio-Pleistocene (Hungerbühler et al. 2002). The main soil types of the páramo are Andosols and Histosols, both of which have very high water retention capacities (Buytaert et al. 2005).

\section{b. Podocarpus National Park}

The region of the San Francisco basin geologically belongs to the palaeozoic Chiguinda unit, and is dominated by metasiltstones, quarztites and siltstones, which are accompanied by layers of phyllite and clay schists (Litherland et al. 1994, Hungerbühler et al. 2002).

The main soil type of the Podocarpus National Park region is Histosol, which dominates in all altitudes and slope classes at least in the area of the San Francisco basin (lower montane forest site) (Liess et al. 2009). Associated soils here are Stagnosols, Cambisols and Regosols, to a small extent also Umbrisols and Leptosols (Liess et al. 2009).

In the investigated study areas of the Matrix plots of the premontane forest (PMF, Bombuscaro, $1000 \mathrm{~m}$ a.s.l.), lower montane forest (LMF, San Francisco, $2000 \mathrm{~m}$ a.s.I) and upper montane forest (UMF, Cajanuma, $3000 \mathrm{~m}$ a.s.I.), soil analyses gave the following results: Soils at the lower slope positions, at midslope positions and on well drained ridge positions of the premontane $(1000 \mathrm{~m}$ a.s.l.) and lower montane (2000 m a.s.l.) forest sites are Eutric or Dystric Cambisols (Wolf et al. 2011). At the ridges of the premontane forest which had a thicker organic layer, the main soil type is Humic Cambisol, whereas most ridges of the lower and upper montane forest are dominated by Histic Planosols and Stagnic Histosols, due to water logging (Wolf et al. 2011). The lower and midslope positions of the upper montane forest have Stagnic Cambisols and Planosols as the main soil types (Wolf et al. 2011).

\subsubsection{Climate}

The climate of the study region is complex and heterogeneous, as it is controlled by macro-scale tropical climatic phenomena such as the intertropical convergence zone, the Atlantic trade-wind system and the el Niño southern Oscillation, as well as by local climatic patterns caused by the varying topography of the Andes (Emck 2007, Bendix et al. 2008b, Rollenbeck and Bendix 2011). 


\section{a. Intertropical convergence zone (ITCZ) and El Niño Southern Oscillation (ENSO)}

The intertropical convergence zone (ITCZ) is a climate phenomenon that leads to high precipitation levels throughout the tropics. At the junction of the trade wind systems coming from

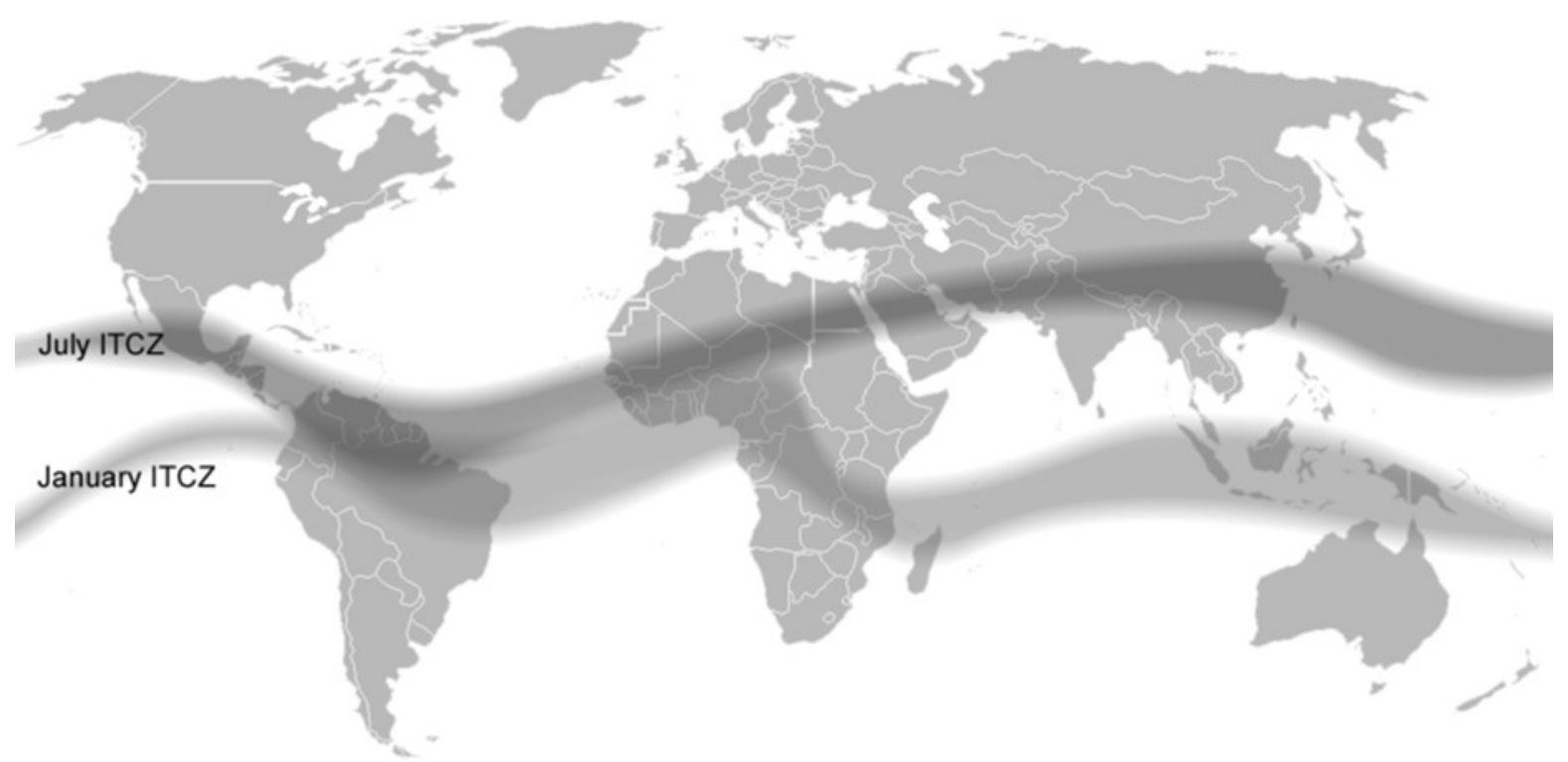

Figure 4 Position of the Inter-tropical Convergence zone at different times of the year. (Source: Wikipedia.org)

north-east and south-west, the ITCZ forms a convective band around the equator, carrying moist air masses that lead to high levels of precipitation (Grodsky and Carton 2003).

Especially the western Andean Cordillera in Ecuador is influenced by the positioning of the ITCZ. As it follows the sun's zenith point, the ITCZ moves north and south in the course of a year. In October, it is located further north $\left(>=10^{\circ} \mathrm{N}\right.$, see Fig. 4), and the southwestern Ecuadorian region at ca. $4^{\circ} \mathrm{S}$ receives only moderate precipitation. From February to April, the ITCZ is located at the equator and the Pacific at the Ecuadorian coast has its highest annual temperatures. This eventually leads to the rise of moist air masses over the coast up to the Sierra and increases precipitation levels especially at the western Andean Cordillera up to the interandean valleys (Emck 2007).

Whereas at the western slopes of the South Ecuador Andes, the El Niño Southern Oscillation (ENSO) phenomenon has a big impact on the climatic pattern and leads to strongly increased rainfalls during El Niño years, no such effect can be recorded east of the divide (Emck 2007).

Even though the effects of ENSO on the eastern Andes in South Ecuador are not fully resolved, higher wind speeds, increased air temperatures seem to be features during El Niño years (Emck 2007). However, precipitation signals are diffuse and irregular (Bendix et al. 2008a). 


\section{b. Regional and local climate}

Generally, the climate is humid, tropical and montane. It is largely controlled by the tropical trade wind regime which carries easterly winds laden with moisture across the Amazon basin to the Andes (Bendix et al. 2008b).

Locally, these patterns are strongly influenced by the rugged terrain of the Andes. In the Podocarpus National Park, the uppermost region of Cajanuma is dominated by the south-easterly trade winds. However, friction at the irregular canopy layer and turbulence can cause the winds

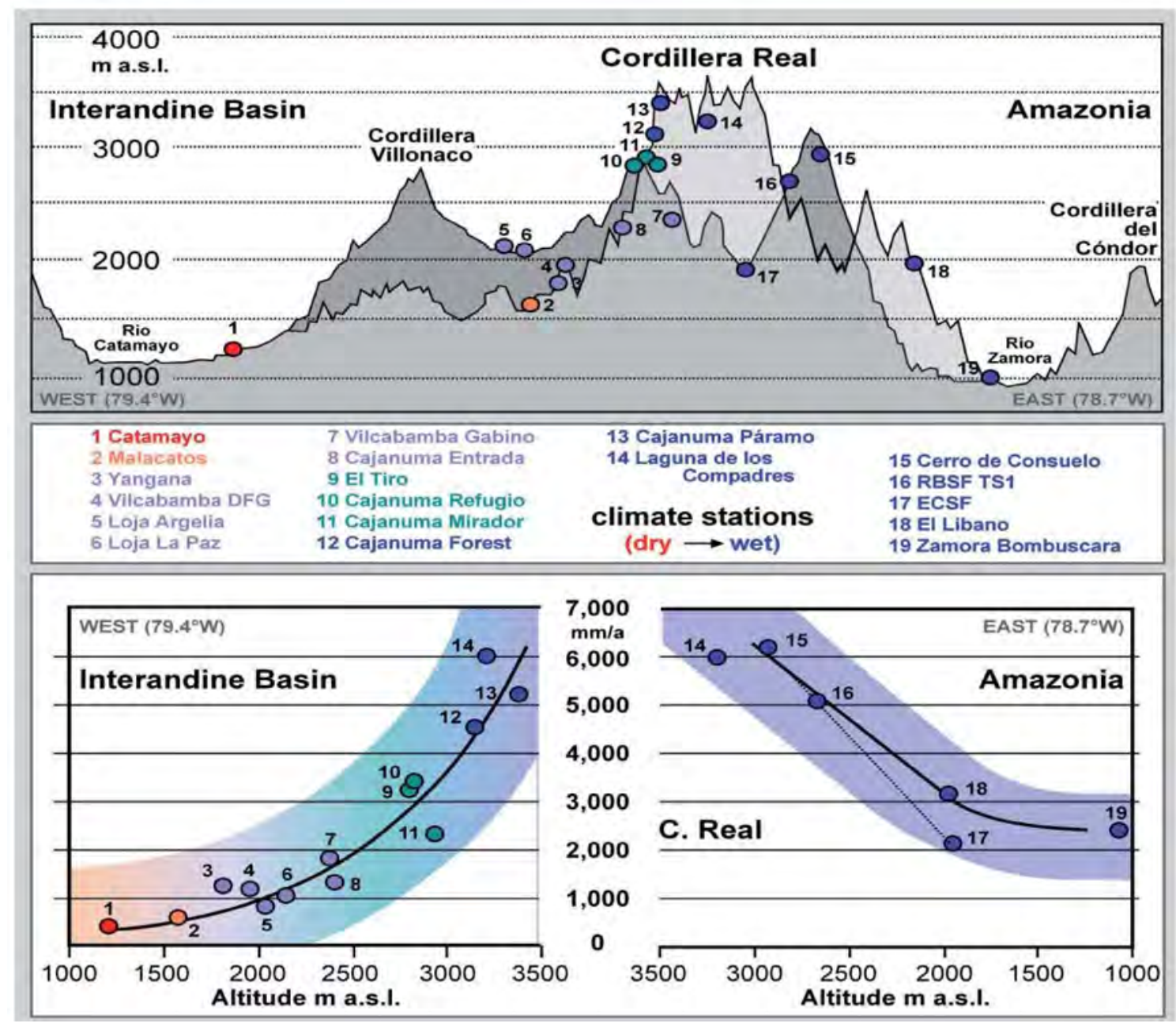

Figure 5 Precipitation gradients east and west of the Cordillera Real in South Ecuador. (Source: Richter et al. 2009).

to turn to a north-western direction at the lee sides of the mountains (Richter et al. 2008).

The area around the Rio San Francisco is controlled by a moderately fresh along-valley southwesterly breeze with downstream movements (Emck 2007). At Bombuscaro, a similar windsystem seems to occur less uniformly and more adynamically (Emck 2007).

In the Andean depression, cloud frequency is very high (70-75\%) and a persistent fog belt below $3600 \mathrm{~m}$ a.s.I. leads to increased precipitation (Hansen et al. 2003, Bendix et al. 2004). Generally, 
precipitation patterns are very irregular and complex, both spatially and temporally, due to the interaction of different cloud systems, regional mountain/valley breeze systems and terrain-lines of favoured moisture transport (Rollenbeck and Bendix 2011). Precipitation levels are generally high without longer dry periods. However, the most humid months occur from April to July, with an average monthly precipitation between 200 and $800 \mathrm{~mm}$, whereas it ranges around 100 to 400 $\mathrm{mm} /$ month during the rest of the year (Bendix et al. 2008b). Along the altitudinal gradient, annual precipitation increases from $2230 \mathrm{~mm}$ at $1000 \mathrm{~m}$, and $1950 \mathrm{~mm}$ at $2000 \mathrm{~m}$, to $4500 \mathrm{~mm}$ at 3000 $m$ in the Podocarpus National Park (Moser et al. 2007, Bendix et al. 2008, Fig. 5).

Temperature changes considerably along the altitudinal gradient. In the eastern Cordillera, temperatures are at an annual average between 25 and $19^{\circ} \mathrm{C}$ below $1100 \mathrm{~m}$. They decrease to 19$13^{\circ} \mathrm{C}$ between 1100 and $2200 \mathrm{~m}$ a.s.l. and further to $13-6^{\circ} \mathrm{C}$ between 2200 and $3600 \mathrm{~m}$ a.s.l. and 6$0^{\circ} \mathrm{C}$ between 3600 and $4800 \mathrm{~m}$ a.s.l., corresponding to a temperature lapse rate of $0.61{ }^{\circ} \mathrm{C} * 100$ $\mathrm{m}^{-1}$ (Beck et al. 2008, Bendix et al. 2008b).

\subsubsection{Flora and Vegetation structure}

\section{a. Podocarpus National Park}

In the study region around the Podocarpus Nationalpark, four different vegetation types have been investigated, following the characterisation of Homeier et al. (2008)

\section{Premontane forest (PMF)}

The evergreen premontane forest (PMF, Fig. 6) in the area of Bombuscaro in the province of Zamora-Chinchipe is found at altitudes between 800 and $1300 \mathrm{~m}$ a.s.I.. Here, canopy heights reach up to $40 \mathrm{~m}$. Characteristic plant families and taxa are Arecaceae (Ceroxylon amazonicum, Euterpe precatoria, Iriartea deltoidea, Oenocarpus bautea), Bombacaceae

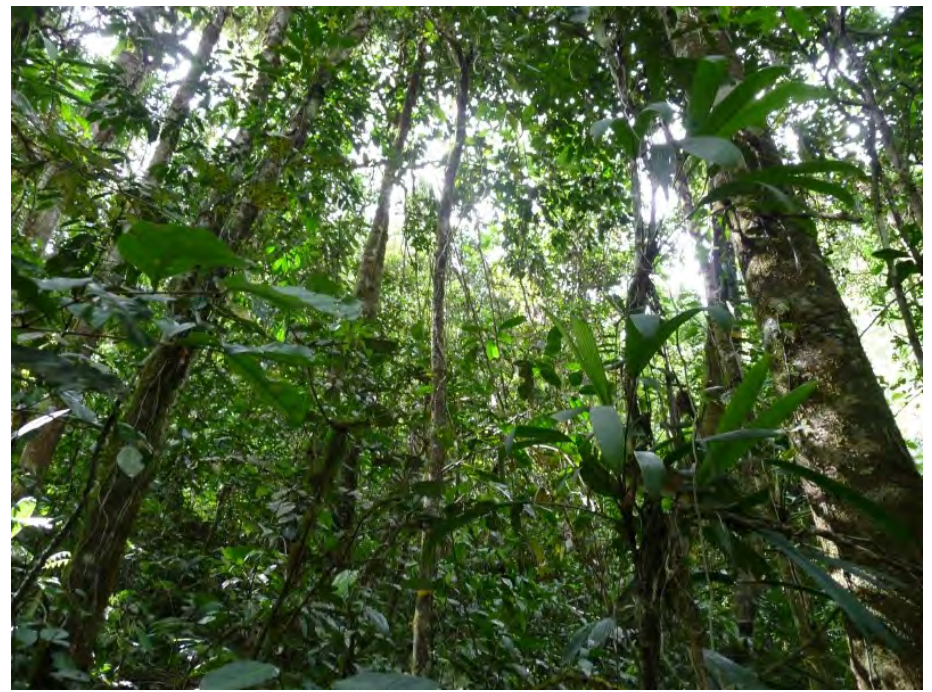

Figure 6 Premontane forest of Bombuscaro (ca. $1000 \mathrm{~m}$ a.s.l.).

(Ochroma pyramidale), Combretaceae (Terminalia amazonica, T. oblonga), Lecythidaceae (Grias peruviana), Moraceae (Clarisia racemosa, Ficus spp., Sorocea trophoides), Piperaceae (Piper spp.), Rubiaceae (Palicourea guianensis, Psychotria spp.), Sapotaceae (Pouteria spp.). 


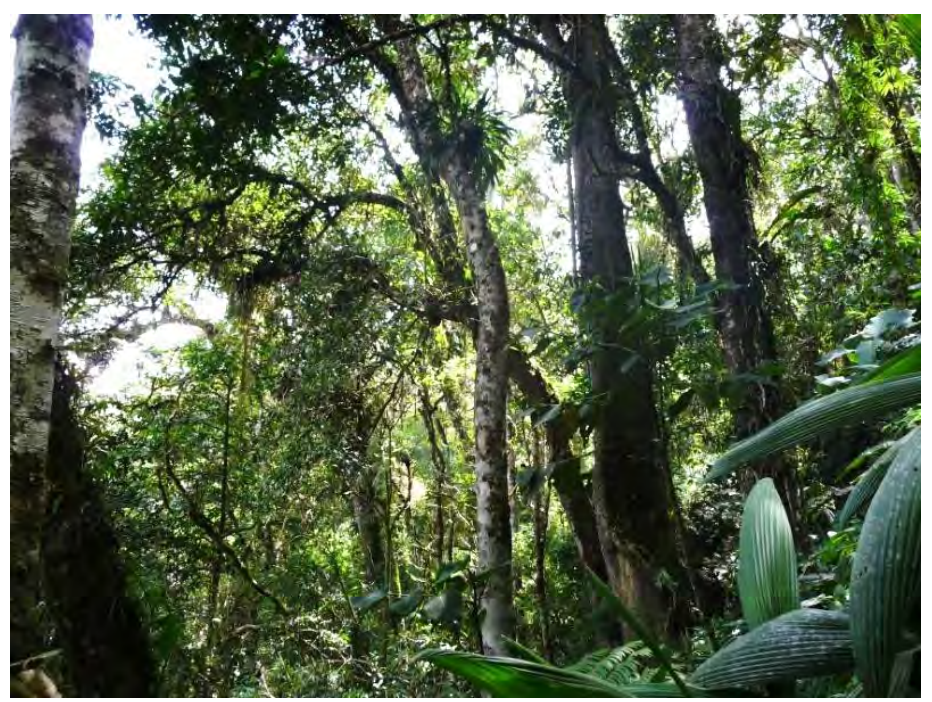

Figure 7 Lower montane forest of the San Francisco area. (ca. $2000 \mathrm{~m}$ a.s.I.).

The investigated area around the San Francisco research station is covered by evergreen lower montane forest (LMF, Fig. 7), with trees of up to $30 \mathrm{~m}$ height. Most prominent taxa and families of this vegetation type, which is found at altitudes from ca. 1300 to $2000 \mathrm{~m}$ a.s.l., are: Alzateaceae (Alzatea verticillata), Arecaceae (Chamaedorea pinnatifrons, Dictyocaryum lamarckianum and Wettinia maynensis), Asteraceae (Piptocoma discolor, Mikania spp.), Bignoniaceae (Tabebuia chrysantha), Clusiaceae (Vismia tormentosa), Cyatheaceae (Cyathea caracasana), Fabaceae (Inga spp.), Lauraceae (Nectandra lineatifolia, N. membranacea, Ocotea aciphylla), Melastomataceae (Miconia imitans, M. punctata), Meliaceae (Cedrela montana), Moraceae (Ficus spp, Morus insignis, Sorocea trophoides), Piperaceae (Piper spp.) and Malvaceae (Heliocarpus americanus).

\section{Upper montane forest (UMF)}

The upper montane forest (UMF, Fig. 8) at Cajanuma grows at altitudes from ca. 2700 to $3100 \mathrm{~m}$ a.s.l. and forms the upper forest line. Trees in this vegetation type are characterised by a low height of ca. 6-8 $\mathrm{m}$. Important taxa are: Aquifoliaceae (llex spp.), Bromeliaceae (Puya eryngioides), Chloranthaceae

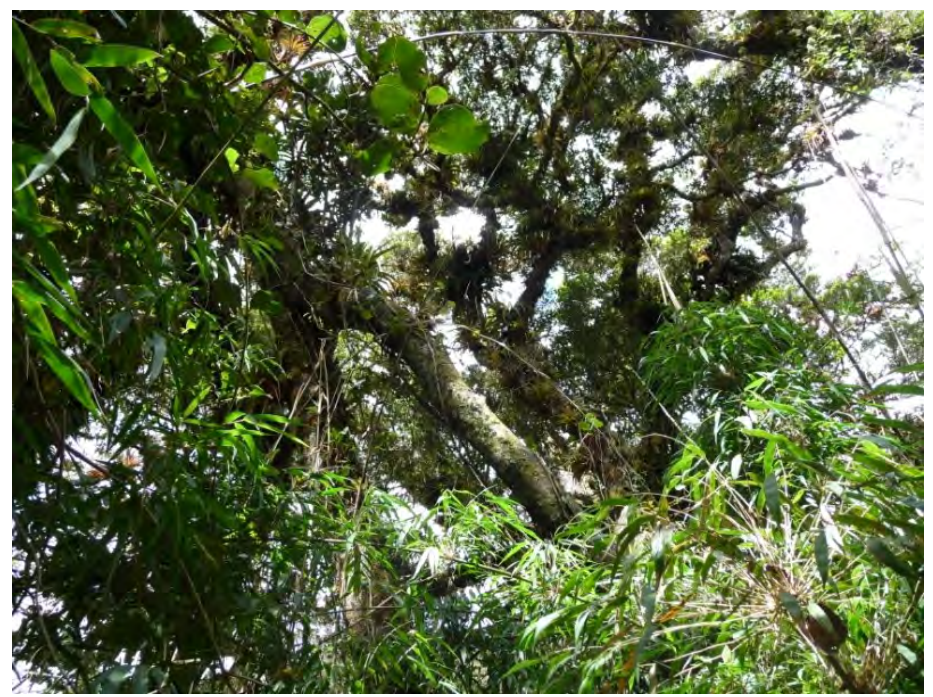
(Hedyosmum cumbalense, H. Figure 8 Upper montane forest of Cajanuma (ca. $2800 \mathrm{~m}$ a.s.l.). scabrum), Clethraceae (Clethra ovalifolia), Clusiaceae (Clusia elliptica), Cunoniaceae (Weinmannia cochensis, W. loxensis, W. rollottii), Ericaceae (Gaultheria reticulata), Grossulariaceae (Escallonia myrtilloides), Iridaceae (Orthrosanthus chimborazensis), Lauraceae (Persea ferruginea, Ocotea infravoveolata), Loranthaceae (Gaiadendron punctatum), Melastomataceae (Graffenrieda 
harlingii), Myrtaceae (Myrteola phylicoides), Rosaceae (Hesperomeles ferruginea), Styracaceae (Styrax foveolaria), Symplocaceae (Symplocos sulcinervia), Theaceae (Gordonia fruticosa), and dense stands of bamboo (Chusquea falcata and C. scandens (Poaceae)).

\section{Páramo}

The páramo of the Cajanuma region (Fig. 9), which occurs at altitudes from ca. 3100 to $3700 \mathrm{~m}$ a.s.l., is characterised by a diverse physiognomy with herbs, shrubs and treelets that can obtain heights of up to $2 \mathrm{~m}$. Important families and taxa for this páramo are:

Asteraceae (Gynoxis spp.), Bromeliaceae (Puya eryngioides, Puya nitida), Clusiaceae (Hypericum decandrum), Cyperaceae

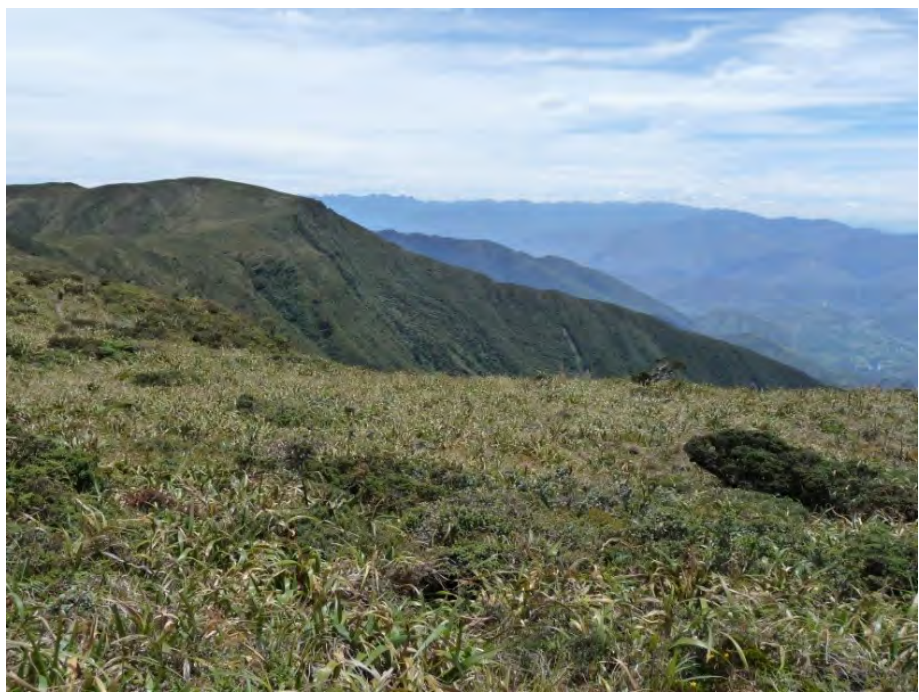

Figure 9 Páramo at Cajanuma (ca. 3300 m a.s.l.).

(Rhynchospora vulcani), Ericaceae (Bejaria resinosa, Disterigma pentandrum, Gaultheria erecta, G. reticulata, Vaccinium floribundum), Grossulariaceae (Escallonia myrtilloides), Melastomataceae (Brachyotum andreanum), Poaceae (Neurolepis asymmetrica, N. elata, N. laegaardii, Chusquea neurophylla), Polygalaceae (Monnina arbuscula), Valerianaceae (Valeriana microphylla, V. plantaginea).

\section{b. Quimsacocha}

\section{Páramo}

The páramo at the Quimsacocha volcanic basin (Fig. 10) is dominated by tussock plants which grow along with acaulescent rosettes and prostrate herbs, as described by Ramsay and Oxley (1997). Recorded taxa of this páramo are: Apiaceae (Eryngium spp., Hydrocotyle spp.) Asteraceae

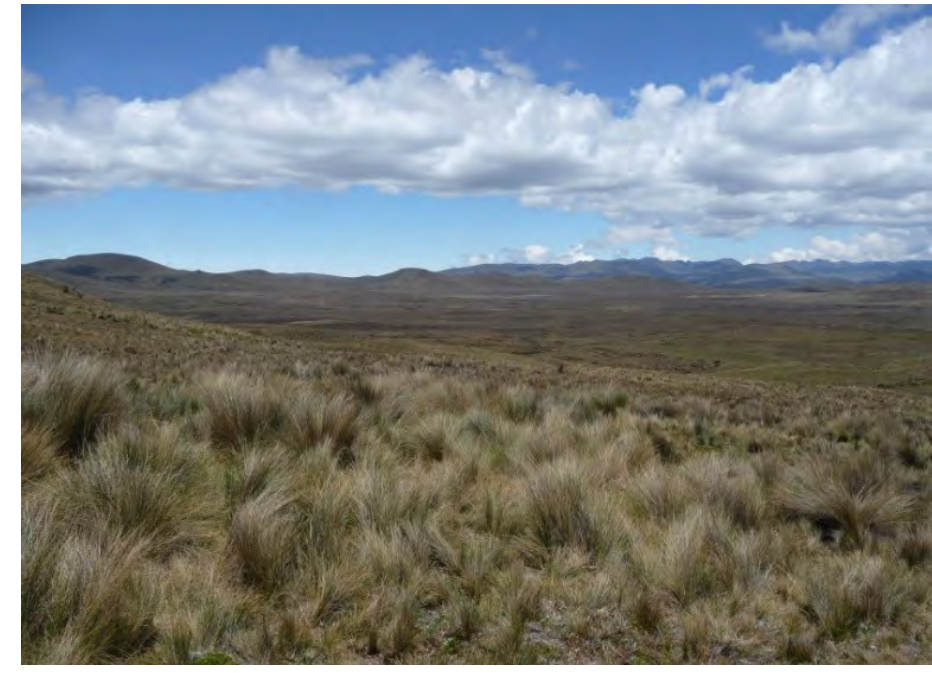

Figure 10 Páramo at Quimsacocha (ca. 3800 m a.s.l.). 
(Baccharis spp., Chuquiraga jussieui, Gynoxis spp., Diplostephium spp., Werneria spp., Loricaria spp.), Bromeliaceae (Puya clava-herculis), Campanulaceae (Lysipomia spp.), Cyperaceae, Fabaceae (Lupinus spp.), Gentianaceae (Gentianella spp., Halenia spp.), Geraniaceae (Geranium spp.), Lycopodiaceae (Huperzia spp.), Plantaginaceae (mostly Plantago rigida) and Poaceae (Stipa spp., Calamagrostis spp., Paspalum spp., Cortaderia spp.) (AMBIGEST 2005, personal observation).

\section{Exotic tree species}

Introduced tree species play a big role in the managed forests of Ecuador. Pine (Pinus spp., Fig.

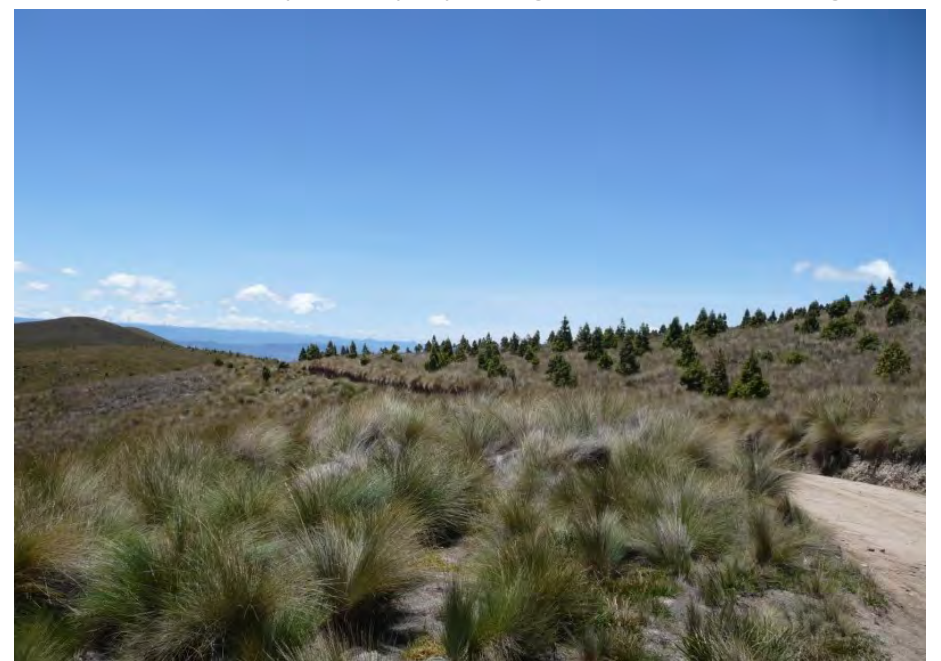
11) and Eucalyptus plantations are common features of the modern Ecuadorian landscape. They are especially found above the modern tree line at altitudes between 3000 $4000 \mathrm{~m}$ a.s.l. where they replace páramo vegetation (Hofstede et al. 2002, Farley 2007). Due to the fact that little knowledge was available

Figure 11 Pine plantation at the Quimsacocha volcanic basin.

about the forestry characteristics of local species and the rapid growth of the exotics in a time of growing demand for timber, national forestry programs have supported the plantation of pine and Eucalyptus until recently (Hofstede et al. 2002).

\subsection{Methods of pollen analysis}

Pollen grains serve as reproductive units of seed plants, as they contain the microgametophytes which are needed for fertilization. Pollen grains ideally travel from one plant to another, to ensure a genetic exchange between individuals. Different dispersal mechanisms have been evolved for this purpose, the most common ones being wind dispersal and animal dispersal. However, as the way from one plant (part) to the other is usually comparatively large, given the size of a single pollen grain (ca. 5-100 $\mu \mathrm{m}$ ), plants produce higher quantities of pollen grains, most of which never serve for fertilization (Birks and Birks, 1980). To prevent a destruction of pollen grains during the transport period, they have developed a very stable coat, the exine, which consists of sporopollenin and withstands harshest environmental conditions. It can generally be preserved for thousands of years, given anoxic conditions. As pollen grains of different plant groups evolved into different shapes, they can be distinguished to a certain taxonomic level by analysing them under the microscope (Faegri and Iversen, 1950). This makes it possible for palynologists to 
reconstruct past vegetation dynamics by distinguishing and counting pollen grains of taxa which once inhabited a given region. Furthermore, as many plant taxa can be assigned to specific environmental niches and have different optima concerning climate, insolation, nutrients and other environmental factors, these can be reconstructed as well, giving a broad picture of a past environment. In general, palaeoecologists analyse sediment cores obtained from an anoxic environments which allow the reconstruction of a timeline with specific dating methods, such as radiocarbon dating.

However, to draw more specific conclusions, modern pollen dispersal mechanisms have to be known. This information can be obtained by investigating the relationship between pollen rain and vegetation on a given site by analysing pollen spectra from surface samples or pollen traps (see chapter 4 for a detailed explanation on the methodology of pollen traps).

In order to obtain pollen which can be investigated under microscope at magnifications of 400 to 1000 , both sediment samples and pollen trap samples have to be processed in the laboratory.

\subsubsection{Processing sediment samples}

Both, palaeosediments and modern sediments contain large quantities of organic and inorganic material which have to be removed in order to get a clean sample which greatly facilitates pollen analysis. The samples were first treated with a solution of $10 \%$ Hydrochloric acid $(\mathrm{HCl})$, which ensures the dissolution of larger particles and Lycopodium clavatum tablets. The Tres Lagunas sediment core samples and surface samples from the páramo were further treated with a solution of $72 \%$ hydrofluoric acid (HF) for one day in order to remove silicate. A solution of $5 \%$ potassium hydroxide $(\mathrm{KOH})$ was applied to the samples which were then heated for 10 minutes to break down organic components. Afterwards, the samples were filtered using a sieve with a mesh size of $150 \mu \mathrm{m}$ to remove larger particles. Subsequently, the most characteristic processing step for palynology, the acetolysis, was applied. For this step, the sample has to be dry, as the acid reacts highly sensitive to water. A dehydration of the sample was reached by adding acetic acid $\left(\mathrm{CH}_{3} \mathrm{COOH}\right)$ to the sample. Then, a 9:1 mixture of acetic anhydride $\left.\left(\mathrm{CH}_{3} \mathrm{CO}\right)_{2} \mathrm{O}\right)$ and concentrated sulphuric acid $\left(\mathrm{H}_{2} \mathrm{SO}_{4}\right)$ was applied and the samples were heated for 10 minutes at ca. $90^{\circ} \mathrm{C}$. This process cleans the samples and stains the pollen and spore grains which makes them more visible for analysis under the microscope. For preparation of pollen slides for the counting process, glycerine gelatine was chosen as a medium. The microscope used for pollen counting was a Zeiss Axiostar Plus, with magnifications 400 and 1000. 


\subsubsection{Processing Behling Trap samples}

The method described here is valid only for Behling traps. For processing of other trap types used in this thesis see Chapter 4. A Behling trap sample is a test tube of $60 \mathrm{~cm}^{3} . \mathrm{HCl}$ and Lycopodium clavatum spores were added to the samples, as described in section 1.3.1. After the first washing process, the samples, consisting of synthetic cotton in which the pollen was, were transferred to a filter covered by a sieve (150 $\mu \mathrm{m}$ mesh width). After sieving and centrifuging, the supernatant was transferred into $15 \mathrm{ml}$ test tubes and acetolysis and the subsequent processing steps were carried out as explained above.

\subsection{Palynological and Palaeoecological findings in the northern/central tropical Andes}

\subsubsection{Vegetation and Climate history since the early Holocene}

Early Holocene (ca. 11,500 cal. yr BP to ca. 8000 cal. yr BP)

After slow warming under moist conditions during the late Pleistocene in the south Ecuadorian Andes (Brunschön and Behling 2010), the earliest Holocene (ca. 11,500-ca. 8000 cal. yr BP) is generally marked as a warmer and moist period compared to the late Pleistocene. This is indicated in many records by greater abundance of pollen taxa deriving from the tropical mountain forest (Hansen and Rodbell 1995, Colinvaux et al. 1997, Hansen et al. 2003, Brunschön and Behling 2009, Villota et al. 2012). Around 8500 cal. yr BP, vegetation signals do not show a uniform pattern throughout the northern/central Andes region. For some lake sites in southern Ecuador (Laguna Rabadilla de Vaca and Laguna Cocha Caranga) and northern Peru (Laguna de Chochos) the beginning of a dry and warm phase, continuing until the mid-Holocene, is indicated by rising importance of taxa growing under shallow lake conditions (Bush et al. 2005, Niemann et al. 2009, Niemann and Behling 2009a). In other archives in Peru and Colombia vegetation signals point to an increase in humid forest taxa, suggesting this phase to have been rather moist and warm (Hansen and Rodbell 1995, Marchant et al. 2002, Velez et al. 2006).

First human impact is reported from various sites throughout the Ecuadorian Andes. Archeological sites record presence of human settlements at 11,000 BP at El Inga near Quito (Mayer-Oakes 1986), at Cubilan, ca. $100 \mathrm{~km}$ north of Loja (Temme 1982 in Valdez 2008) and at Chobshi Cave, close to Cuenca (Lynch and Pollock 1971 in Valdez 2008). In the south-western coastal region of Ecuador, Cucurbita-domestication could be dated back to 9320 cal. yr BP (Piperno and Stothert 2003). Single palaeoenvironmental records evidence higher concentration of charcoal particles suggesting increased fire activity possibly due to human impact (Weng et al. 2006, Niemann and Behling 2009a). 


\section{Mid-Holocene (ca. $8000-4000$ cal. yr BP)}

The mid-Holocene is a markedly dry phase in most of the sites studied in the north and central Andes region of Colombia, Ecuador, Peru and Bolivia (Hansen et al. 2003, Paduano et al. 2003, Rull et al. 2005, Weng et al. 2006, Gómez et al. 2007, Jantz and Behling 2011). However, this midHolocene dry event varies considerably in magnitude and time span throughout the northern/central Andes region. The current view suggests a time-transgressive reoccurrence of moister conditions for the central Andes of Bolivia and Peru, with a stronger and more severe dry period in the Andes of Bolivia than further northwards (Abbott et al. 2003). However, this pattern is not completely uniform throughout the region, as for example for Laguna Pacucha in Southern Peru, volatile lake levels rather than a complete drying out are reported (Hillyer et al. 2009, Valencia et al. 2010). Generally, the peak of the event and its drift velocity, which is assumed to have been between ca. $1^{\circ}$ latitude per millennium to up to $2^{\circ}$ latitude per millennium from north to south, are still not completely resolved and need to be studied further (Abbott et al. 2003, Bush et al. 2005). Whereas a severe dry phase occurring between 6000 and 2400 cal. yr BP is reported from Taypi Chaka Kkota in Central Bolivia (Abbott et al. 2003), at Lake Titicaca in southern Peru/Bolivia, a dry phase is recorded between ca. 9000-3100 cal. yr BP with a peak between 6000 and 4000 cal. yr BP (Paduano et al. 2003). Further north, at Laguna la Compuerta in northern Peru (Weng et al. 2006), a dry-event covers the early to mid-Holocene period from 10,000 to 5500 cal. yr BP with a peak at ca. 8500 cal. yr BP. In Ecuador and Colombia, signals are more diffuse. In the Podocarpus National Park, an area with generally very humid climatic conditions, a drier phase, starting in the early Holocene, continues until the beginning of the mid-Holocene (ca. $6900 \mathrm{cal}$. $\mathrm{yr}$ BP at Laguna Cocha Caranga (Niemann and Behling 2009a) and ca. 6380 cal. yr BP at Laguna Rabadilla de Vaca (Niemann et al. 2009)). However, the role of a drier mid-Holocene period in the southwestern part of the Ecuadorian Andes region has not been addressed up to this point.

Shifts to more xeric biomes are reported for many palaeo-environmental records throughout Colombia at a time-slice at 6000 cal. yr BP (Marchant et al. 2002). Generally, a change of orbital parameters resulting in higher solar insulation during boreal and equatorial summer is thought to be the responsible trigger mechanism for the mid-Holocene dry phase (Berger and Loutre 1991). Direct consequences could have been changes in the sea surface temperature (SST) gradient across the tropical Pacific, which would strengthen easterly winds and lead to a seasonally cooler eastern Pacific (Clement et al. 2000). Also, indirectly, a north shift of the ITCZ mean position caused stronger south-easterly trade-winds, increased oceanic upwelling, lower SSTs and reduced precipitation (Mitchell and Wallace 1991, Haug et al. 2001, Conroy et al. 2008). 
Human impact is suggested for various sites throughout the northern/central Andes region. Indicators are increases in charcoal concentrations in sediment records that point to anthropogenic influences by the use of fire (Niemann and Behling 2008, Jantz and Behling 2011).

\section{Late Holocene (ca. 4000 cal. yr BP to the present)}

During the course of the late Holocene, climate changes towards more humid and slightly cooler conditions at many sites in the Andes of Bolivia (Abbott et al. 2003), Peru (Weng et al. 2006, Urrego et al. 2011a), Ecuador (Niemann and Behling 2008, 2009a) and Colombia (Marchant et al. 2002). As in previous periods throughout the Holocene, vegetation and climate signals are not the same throughout the region of the northern/central Andes. For the Podocarpus National Park, Niemann and Behling (2009a) report cooler but drier climatic conditions for the late Holocene at Laguna Cocha Caranga. At Laguna Rabadilla de Vaca, a lake level lowstand is indicated by the dominance of Cyperaceae and low concentration of Botryococcus from 4200 to ca. 1300 cal. yr BP. Afterwards, a peat bog established at the site, pointing to moist conditions (Niemann et al. 2009). However, in most records, this period has generally stable climatic conditions (Rodríguez and Behling 2010). Human impact becomes stronger at most of the sites during the last millennia, shown by the presence of pollen grains of Zea mays and Amaranthaceae/Chenopodiaceae as indicators for local agriculture (e.g. Hansen et al. 2003, Niemann and Behling 2009b, Valencia et al. 2010). Other signals are taxa that can indicate disturbance and forest clearings, e.g. Alnus, Ambrosia, Chenopodiaceae/Amaranthaceae, Dodonaea (e.g. Hansen et al. 2003, Gómez et al. 2007, Brunschön and Behling 2009, Valencia et al. 2010) and high charcoal concentrations (Niemann and Behling 2008, 2009b, Brunschön and Behling 2009, Rodríguez and Behling 2010, Valencia et al. 2010, Urrego et al. 2011a).

\subsubsection{Studies on modern pollen rain}

One purpose of modern pollen rain studies is to determine dispersal characteristics of pollen taxa for a more quantitative reconstruction of palaeoecological conditions. This is very dependent on local vegetation processes and the present biotic and abiotic factors a region is exposed to. Pollen/vegetation relationships have been studied in a variety of different ecosystems and altitudes across the tropical Andes, each with different climatic and edaphic characteristics that control plant abundance and pollen dispersal (Fig. 12, see also Appendix 1 for an overview of locations as well as of the methodological scope of other modern pollen rain studies carried out in the northern/central Andes). Also, a pollen taxon usually consists of more than one species or genus, making direct comparisons between different regions complicated, as each species/genus 
has its own ecological properties and dispersal power. Nevertheless, for many taxa, general patterns are visible, which can help to gain a comprehensive overview and to interpret palaeodata at least in qualitative terms. First studies on modern pollen rain in the northern/central Andes region were undertaken by Maria Lea Salgado-Labouriau (1979) in Venezuela. She discovered the need of studying modern pollen deposition to improve the basis for interpretation of palaeodata. She analysed surface samples along an altitudinal transect from

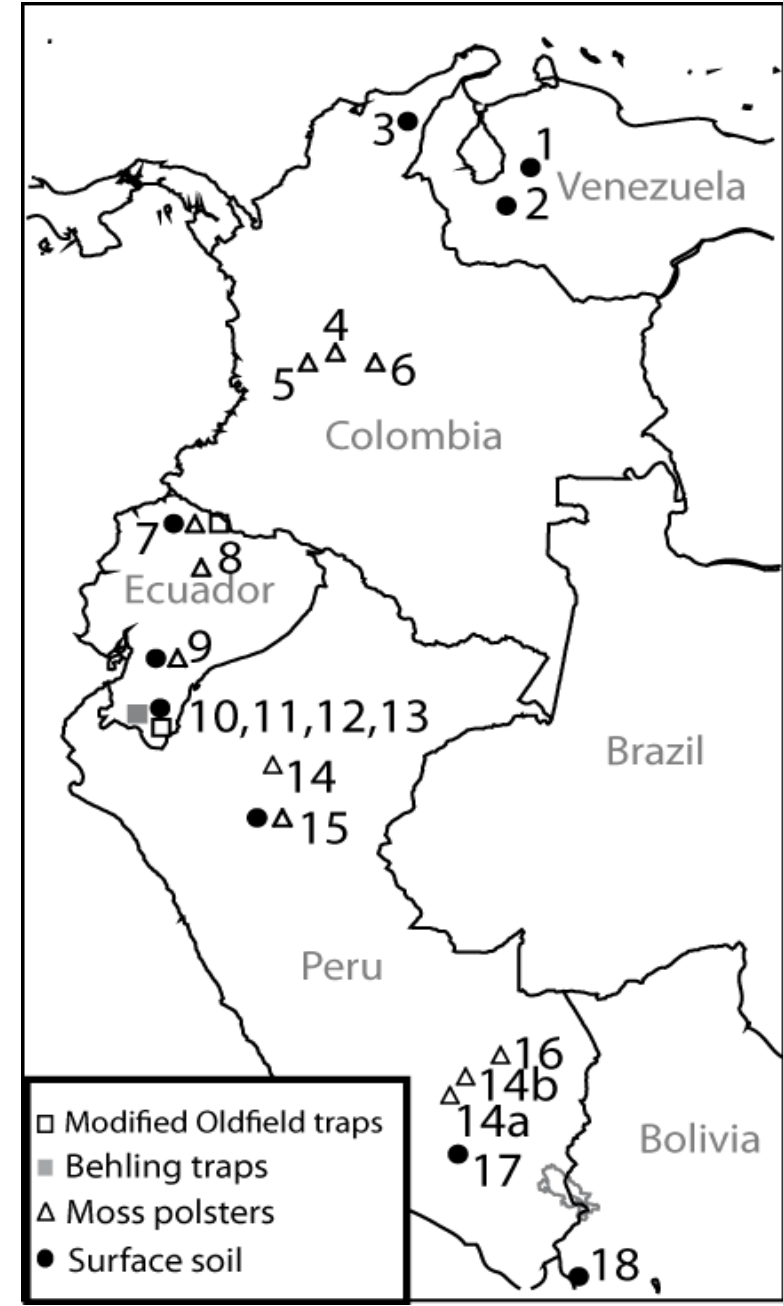

Figure 12 Location of different modern pollen rain study sites across the northern/central Andes region. 1: SalgadoLabouriau 1979, 2: Rull 2006, 3: Melief 1984, 4: Witte 1994, 5: Rangel-Ch. 2005, 6: Grabandt 1980, 7: Olivera et al. 2009, 8: Wille et al. 2002, 9: Hansen et al. 2003, 10: Niemann et al. 2010, 11-13: Jantz et al. 2013 a,b,c (see chapters 3-5 of this thesis), 14: Urrego et al. 2011b, 15: Hansen and Rodbell 1995, 16: Weng et al. 2004, 17: Kuentz et al. 2007, 18: Reese and Kam-Biu 2005.
3420 to $4340 \mathrm{~m}$ a.s.l. for pollen composition and abundance. In her study, first general conclusions about pollen distribution patterns, dispersion power of different taxa, long-distance transport and the distinction of different vegetation types were made. The main taxa she found to have a high to moderate dispersal power were Alnus, Hedyosmum and Podocarpus (SalgadoLabouriau 1979). A compilation of ecological information on taxa derived from modern pollen rain studies across the tropical Andes region is summarized in Appendix 2.

Only one year later, a very extensive study, based on 15 transects along an altitudinal gradient from 300 to $4000 \mathrm{~m}$ a.s.l., gave valuable insights into a wide range of vegetation types of the Colombian Andes (Grabandt 1980). Based on the calculation of ratios between vegetation and pollen percentage data (t(v)/p-values), first quantitative estimations about taxa representation could be given. Here, Alnus, Myrica, Hedyosmum, Quercus, Acalypha and

Alchornea are interpreted to be the best pollen producers of Andean/Subandean forests (Grabandt 1980). Since then, several studies have extended views on patterns and productivity of pollen spectra in the Andes by using different approaches to make statements about representation of pollen taxa. Besides the $t / p$-values that have been used in other studies on 
modern pollen rain along the forest/páramo ecotone in Colombia (Melief 1984) and Ecuador (Olivera et al. 2009), these include representation indices (Davis 1984), which give a good overview about general over- or underestimation and association of pollen taxa in a given vegetation type. They can provide very simple tools for which only presence/absence data of pollen and plant taxa are needed (Rangel-Ch. 2005, Olivera et al. 2009, Jantz et al. 2013 (Chapter 3)). Another method, used by Melief (1984), is the R-Value, which establishes pollen percentage/vegetation ratios to cope with the effect of biased percentage data that prohibit a quantitative interpretation of pollen percentage diagrams. The R-value, which was developed by Davis (1963) and inspired by earlier authors (Faegri and Iversen 1950) seeks to correct pollen data by creating ratios between pollen and vegetation data The model has been extended several times to create the best fit between pollen and vegetation data (Parsons and Prentice 1981, Prentice 1985, 1985, see also Giesecke et al. 2010). Due to an extent methodology which requires careful vegetation analyses and profound knowledge about the modern pollen rain - vegetation pattern, it has in its newest form not yet been applied to tropical vegetation. Other approaches are the pollen-class rank vs. vegetation-class rank method applied by Witte (1994) and probability density functions (PDFs) of pollen abundance along an altitudinal gradient which were compared to plot abundance, basal area and herbarium collection data along the same gradient. These gave a good impression about the reflection of vegetation composition in the pollen data (Urrego et al. 2011b). Multivariate data analyses could help to detect patterns of modern pollen distribution for different vegetation types in the northern/central Andes (Weng et al. 2004, Reese and Kam-Biu 2005, Rull 2006, Kuentz et al. 2007, Olivera et al. 2009, Niemann et al. 2010, Urrego et al. 2011b, Ortuño et al. 2011, Jantz et al. 2013a and b (see Chapters 3 and 4 of this thesis). Few studies established a pollen-climate calibration dataset for specific regions using transfer functions (Rull 2006), or direct correlation with climatic variables (Witte 1994, Urrego et al. 2011b). Whereas a large majority of these studies is based on data obtained from soil surface or moss samples, only few studies worked with pollen traps, which could be used for the estimation of not only representation and distribution patterns of pollen spectra but also of the pollen accumulation rates of vegetation types (Olivera et al. 2009, Niemann et al. 2010) and single pollen taxa (Chapter $5)$. 


\subsection{General objectives and outline of the chapters}

This thesis is dedicated to revelation of past and present vegetation and plant diversity patterns and their responses to climate, fire and land use changes in the South Ecuadorian Andes. As this region is part of one of the five most species-rich biodiversity hot-spots in the world (Myers et al. 2000), it should receive special attention in terms of conservation. Therefore, one goal is to explore past diversity patterns and to understand the role of climate change and human impact in shaping vegetation change in biodiverse ecosystems to link palaeoecology to conservation action (Willis et al. 2007). However, in order to do an accurate palaeoecological reconstruction using palynology as a method, broad knowledge of the present modern pollen rain - vegetation relationship is an important prerequisite. Therefore, the thesis comprises two main parts that seek to link past and present ecological questions related to palynological patterns of Andean montane vegetation:

Investigation of Holocene vegetation, climate, fire and land use dynamics in the South Ecuadorian Andes

As briefly described before, prior palaeoecological studies of the South Ecuadorian Andes reveal a heterogeneity of climate, vegetation, fire and land use patterns across the Podocarpus National Park and its surroundings. A palaeoecological study of the western part of the inter-Andean depression is presented, closing a gap in the palaeoecological knowledg for this region. Another task was to link existing palaoecological records to detect similar developments of past environmental change for different sites in South Ecuador. With palaeoecological studies presented in this thesis, the following research questions were approached:

- Are ecosystem changes at the Quimsacocha volcanic basin related to regional changes during the course of the Holocene?

- Were the western Ecuadorian Andes affected by a mid-Holocene dry phase?

- When did human impact start in the southwestern Ecuadorian Andes?

- Do different sites in the South Ecuadorian Andes show similar patterns of pollen compositional changes during periods of environmental change since the last glacial maximum?

- Can the rate of change of pollen composition detect similar response mechanisms of past environmental change for different sites in the Andes of South Ecuador? 


\section{Investigation of modern pollen rain spectra from different vegetation types across an altitudinal gradient in the South Ecuadorian Andes}

Palaeoecological reconstructions based on palynology rely on knowledge about present pollenrain - vegetation relationships. Enhanced knowledge about reflection of vegetation in modern pollen rain spectra provides a base for a detailed calibration of palaeorecords and leads way towards more quantitative reconstructions of past environmental conditions. Furthermore, modern pollen rain collected with pollen traps is a remote sensing tool that can be used for detection of phenological variation in the vegetation. However, especially in the tropics, work with modern pollen spectra is a difficult task. High pollen taxa richness with a large amount of morphological pollen types which cannot be assigned to a specific phylogenetic group of plant species as well as a high degree of uneven taxa distribution in the samples have to be taken into account. Also, different pollen trapping media record the modern pollen spectrum differently and can bias a palaeoecological calibration dataset. Therefore, our attention lies not only on the modern pollen spectrum itself, but also on the way it is captured by different pollen trapping media frequently used in tropical pollen analysis.

Within this thesis, the following research questions concerning modern pollen spectra and pollen trapping are adressed:

- Can a reduction of plant and pollen data to family level preserve information about diversity in both datasets?

- How precisely do tree pollen and spore types represent diversity patterns along an altitudinal gradient on tropical mountains?

- How similar are tree pollen and spore family diversity in relationship to tree family diversity?

- How precisely can tree pollen and spore types represent presence and abundance patterns of tree taxa in different forest types?

- What are pollen accumulation rates for characterising pollen taxa of the north-central Andean forests?

- Do any of the characteristic pollen taxa show strong inter-annual variations in their pollen accumulation rates (PARs)?

- How strong is the influence of the pollen trap distribution on pollen spectra?

- To what extent do different pollen trap types and soil samples collect pollen rain in a different way and how is this reflected in the data?

- Which pollen trap is most suitable for which tropical vegetation type? 
The chapters of this thesis were prepared as manuscripts for publication in peer-reviewed scientific journals or in the Ecological Studies volume published in the framework of the DFG RU 816 in 2013. The specific aims of the chapters of the thesis are as follows:

Chapter 2 presents the first palaeoecological investigation from the western mountain ridge of the Andean depression in South Ecuador based on a Holocene pollen record from the Quimsacocha volcanic basin. Charcoal and pollen analysis provide a basis for a detailed reconstruction of vegetation, climate and fire history since the early mid-Holocene. A comparison to regional vegetation and climate history creates a comprehensive overview of Holocene environmental developments of South Ecuador.

In Chapter 3 the relationship between modern pollen rain and Andean montane forest vegetation, regarding diversity, is assessed for the three forest types premontane, lower montane and upper montane forest. This is done with Behling pollen traps to provide a basis for interpretations of palaeoecological data in the northern Andes. Taxonomic surrogacy is assessed and applied for plant and pollen data to provide a basis for the comparison of plant and pollen data. Diversity and representation indices of this dataset reveal patterns in pollen versus plant distribution and diversity of different forest ecosystems.

Chapter 4 deals with the comparison of Behling traps, modified Oldfield traps and surface samples as frequently used trapping media for modern pollen rain collection in tropical regions. We compared trapping properties of different media along an altitudinal gradient from ca. 1000 to ca. $3300 \mathrm{~m}$ a.s.l. in southern Ecuador. The vegetation types covered are premontane forest, lower montane forest, upper montane forest and páramo. Pollen assemblage composition, representation, diversity and palynological abundance in modern pollen spectra of Behling traps, modified Oldfield traps, reference traps and soil samples were assessed in comparison to the vegetation. Based on the results, recommendations are given for future studies of modern pollen rain in tropical regions.

Chapter 5 summarizes the analyses of a three year collection of modern pollen rain data using Behling pollen traps from three tropical Andean forest types of south Ecuador: Premontane forest, lower montane forest and upper montane forest. Pollen accumulation rates and their errors are calculated to obtain unbiased data. A palynological characterization of the different ecosystems and an assessment of variation of pollen accumulation rates within spatial and temporal frames provide a detailed and quantitative analysis of modern pollen spectra of the selected Andean vegetation types.

Chapter 6 is a supplementary chapter that combines multivariate analyses of pollen data with analyses of the present upper forest line and water exclusion experiments for testate amoebae to 
detect general patterns and strength of climate change effects on biodiversity and ecosystem functioning in the Podocarpus National Park.

In Chapter 7, the main findings of the first five chapters are summarized and synthezised to give a comprehensive conclusion. Further, possible uncertainties are mentioned and recommendations for improvement of methodological aspects are given. Finally, future research questions are being adressed.

\subsection{References}

Abbott, M., B. Wolfe, A. Wolfe, G. Seltzer, R. Aravena, B. Mark, P. Polissar, D. Rodbell, H. Rowe, and M. Vuille. 2003. Holocene paleohydrology and glacial history of the central Andes using multiproxy lake sediment studies. Palaeogeography, Palaeoclimatology, Palaeoecology 194:123-138.

Balslev, H., and J. Luteyn. 1992. Páramo : an Andean ecosystem under human influence. Academic Press, London; San Diego.

Barthlott, W., A. Hostert, G. Kier, W. Küper, H. Kreft, J. Mutke, M. D. Rafiqpoor, and J. H. Sommer. 2007. Geographic Patterns of Vascular Plant Diversity at Continental to Global Scales. Erdkunde 61:305-315.

Beck, E., F. Makeschin, F. Haubrich, M. Richter, J. Bendix, and C. Valarezo. 2008. The Ecosystem (Reserva Biológica San Francisco). Pages 1-13 in E. Beck, J. Bendix, I. Kottke, F. Makeschin, and R. Mosandl, editors. Gradients in a tropical mountain ecosystem of Ecuador. Springer, Berlin.

Bendix, J., R. Rollenbeck, and W. E. Palacios. 2004. Cloud detection in the Tropics - a suitable tool for climate-ecological studies in the high mountains of Ecuador. International Journal of Remote Sensing 25:4521-4540.

Bendix, J., R. Rollenbeck, P. Fabian, P. Emck, M. Richter, and E. Beck. 2008a. Climate variability. Pages 281-290 in E. Beck, J. Bendix, I. Kottke, F. Makeschin, and R. Mosandl, editors. Gradients in a tropical mountain ecosystem of Ecuador. Springer, Berlin.

Bendix, J., R. Rollenbeck, M. Richter, P. Fabian, and P. Emck. 2008b. Climate. Pages 63-73 in E. Beck, J. Bendix, I. Kottke, F. Makeschin, and R. Mosandl, editors. Gradients in a tropical mountain ecosystem of Ecuador. Springer, Berlin.

Berger, A., and M. Loutre. 1991. Insolation values for the climate of the last 10 million years. Quaternary Science Reviews 10:297-317.

Birks, H. \& Birks, H. 1980. Quaternary palaeoecology. Edward Arnold, London.

Brunschön, C., and H. Behling. 2009. Late Quaternary vegetation, fire and climate history reconstructed from two cores at Cerro Toledo, Podocarpus National Park, southeastern Ecuadorian Andes. Quaternary Research 72:388-399.

Brunschön, C., and H. Behling. 2010. Reconstruction and visualization of upper forest line and vegetation changes in the Andean depression region of southeastern Ecuador since the last glacial maximum - A multi-site synthesis. Review of Palaeobotany and Palynology 163:139-152.

Bush, M., B. Hansen, D. Rodbell, G. Seltzer, K. Young, B. León, M. Abbott, M. Silman, and W. Gosling. 2005. A 17 000-year history of Andean climate and vegetation change from Laguna de Chochos, Peru. Journal of Quaternary Science 20:703-714.

Buytaert, W., J. Sevink, B. Deleeuw, and J. Deckers. 2005. Clay mineralogy of the soils in the south Ecuadorian páramo region. Geoderma 127:114-129.

Clement, A., R. Seager, and M. Cane. 2000. Suppression of El Niño during the Mid-Holocene by changes in the Earth's orbit. Paleoceanography 15:731. 
Colinvaux, P. A., M. B. Bush, M. Steinitz-Kannan, and M. C. Miller. 1997. Glacial and Postglacial Pollen Records from the Ecuadorian Andes and Amazon. Quaternary Research 48:69-78.

Conroy, J., J. Overpeck, J. Cole, T. Shanahan, and M. Steinitz-Kannan. 2008. Holocene changes in eastern tropical Pacific climate inferred from a Galápagos lake sediment record. Quaternary Science Reviews 27:1166-1180.

Davis, M. 1963. On the theory of pollen analysis. American Journal of Science 261:897-912.

Davis, O. 1984. Pollen frequencies reflect vegetation patterns in a great basin (U.S.A.) mountain range. Review of Palaeobotany and Palynology 40:295-315.

Emck, P. 2007. A climatology of South Ecuador - With special focus on the Major Andean Ridge as Atlantic-Pacific Climate Divide. Dissertation, Universität Erlangen-Nürnberg.

Faegri, K., and J. Iversen. 1950. Text-book of modern pollen analysis. Ejnar Munksgaard, Copenhagen.

FAO. 2006. Global Forest Resources Assessment 2005 - Progress towards sustainable forest management. FAO Forestry Paper, FAO, Rome.

Farley, K. 2007. Grasslands to Tree Plantations: Forest Transition in the Andes of Ecuador. Annals of the Association of American Geographers 97:755-771.

GESTION AMBIENTAL C. LTDA. AMBIGEST. 2005. IAMGOLD áreas mineras 'Cerro Casco' y 'Rio Falso' - Estudio ampliatorio de impacto ambiental y plan de manejo ambiental.

Giesecke, T., W. van der Knaap, and F. Bittmann (Eds.). 2010. Towards quantitative palynology: using pollen accumulation rates and models of pollen dispersal. Vegetation History and Archaeobotany 19.

Gómez, A., J.-C. Berrío, H. Hooghiemstra, M. Becerra, and R. Marchant. 2007. A Holocene pollen record of vegetation change and human impact from Pantano de Vargas, an intra-Andean basin of Duitama, Colombia. Review of Palaeobotany and Palynology 145:143-157.

Grabandt, R. 1980. Pollen rain in relation to arboreal vegetation in the Colombian Cordillera Oriental. Review of Palaeobotany and Palynology 29:65-147.

Grodsky, S., and J. Carton. 2003. The Intertropical Convergence Zone in the South Atlantic and the Equatorial Cold Tongue. Journal of Climate 16:723-733.

Hansen, B., D. Rodbell, G. Seltzer, B. Leon, K. Young, and M. Abbott. 2003. Late-glacial and Holocene vegetational history from two sites in the western Cordillera of southwestern Ecuador. Palaeogeography, Palaeoclimatology, Palaeoecology 194:79-108.

Hansen, B., and D. Rodbell. 1995. A Late-Glacial/Holocene Pollen Record from the Eastern Andes of Northern Peru. Quaternary Research 44:216-227.

Haug, G., K. Hughen, D. Sigman, L. Peterson, and U. Röhl. 2001. Southward Migration of the Intertropical Convergence Zone Through the Holocene. Science 293:1304-1308.

Hillyer, R., B. Valencia, M. Bush, M. Silman, and M. Steinitz-Kannan. 2009. A 24,700-yr paleolimnological history from the Peruvian Andes. Quaternary Research 71:71-82.

Hofstede, R., J. Groenendijk, R. Coppus, J. Fehse, and J. Sevink. 2002. Impact of Pine Plantations on Soils and Vegetation in the Ecuadorian High Andes. Mountain Research and Development 22:159-167.

Homeier, J., F. Werner, R. Gradstein, S.-W. Breckle, and M. Richter. 2008. Potential vegetation and floristic composition of Andean forests in South Ecuador, with a focus on the RBSF. Pages 87-100 in E. Beck, J. Bendix, I. Kottke, F. Makeschin, and R. Mosandl, editors. Gradients in a tropical mountain ecosystem of Ecuador. Springer, Berlin-Heidelberg.

Hungerbühler, D., M. Steinmann, W. Winkler, D. Seward, A. Egüez, D. Peterson, U. Helg, and C. Hammer. 2002. Neogene stratigraphy and Andean geodynamics of southern Ecuador. Earth-Science Reviews 57:75-124.

Jantz, N., and H. Behling. 2011. A Holocene environmental record reflecting vegetation, climate, and fire variability at the Páramo of Quimsacocha, southwestern Ecuadorian Andes. Vegetation History and Archaeobotany 21:169-185.

Jørgensen, P., and S. León-Yánez. 1999. Catalogue of the vascular plants of Ecuador. 
Kreft, H., and W. Jetz. 2007. Global patterns and determinants of vascular plant diversity. Proceedings of the National Academy of Sciences 104:5925-5930.

Kuentz, A., A. de Mera, M.-P. Ledru, and J.-C. Thouret. 2007. Phytogeographical data and modern pollen rain of the puna belt in southern Peru (Nevado Coropuna, Western Cordillera). Journal of Biogeography 34:1762-1776.

Liess, M., B. Glaser, and B. Huwe. 2009. Digital soil mapping in southern Ecuador. ERDKUNDE 63:309-319.

Litherland, M., J. Aspden, and R. Jemielita. 1994. The metamorphic belts of Ecuador. British Geological Survey, Keyworth, Nottingham.

Luteyn, J. 1999. Páramos: A Checklist of Plant Diversity, Geographical Distribution, and Botanical Literature. Memoirs of the New York Botanical Garden Volume 84. New York.

Lynch, T., and S. Pollock. 1971. La arqueología de la Cueva Negra de Chobshi. Miscelánea Antropológica Ecuatoriana 1:92-119.

Marchant, R., H. Behling, J.-C. Berrio, A. Cleef, J. Duivenvoorden, H. Hooghiemstra, P. Kuhry, B. Melief, E. Schreve-Brinkman, B. Van Geel, T. Van der Hammen, G. Van Reenen, and M. Wille. 2002. Pollen-based biome reconstructions for Colombia at 3000, 6000, 9000, 12 000, 15000 and 18 00014C yr ago: Late Quaternary tropical vegetation dynamics. Journal of Quaternary Science 17:113-129.

Mayer-Oakes, W. 1986. El Inga, a Paleo-Indian site in the Sierra of Northern Ecuador. Transactions of the American Philosphical Society 76:1-235.

Melief, A. 1984. Comparison of vegetation and pollen rain on the Buritaca-la Cumbre transect (Sierra Nevada de Santa Marta, Colombia). Pages 547-559 Studies on tropical andean ecosystems 2. J. Cramer (Borntraeger), Berlin-Stuttgart.

Mitchell, T., and J. Wallace. 1991. The Annual Cycle in Equatorial Convection and Sea Surface Temperature. Journal of Climate 5:1140-1156.

Moser, G., D. Hertel, and C. Leuschner. 2007. Altitudinal Change in LAI and Stand Leaf Biomass in Tropical Montane Forests: a Transect Study in Ecuador and a Pan-Tropical Meta-Analysis. Ecosystems 10:924-935.

Mutke, J. and W. Barthlott. 2005. Patterns of vascular plant diversity at continental to global scales. Biologiske Skrifter 55: 521-531.

Mutke, J., J. Sommer, H. Kreft, G. Kier, and W. Barthlott. 2011. Vascular Plant Diversity in a Changing World: Global Centres and Biome-Specific Patterns. Pages 83-96 in F. E. Zachos and J. C. Habel, editors. Biodiversity Hotspots. Springer Berlin Heidelberg, Berlin, Heidelberg.

Myers, N., R. Mittermeier, C. Mittermeier, G. da Fonseca, and J. Kent. 2000. Biodiversity hotspots for conservation priorities. Nature 403:853-858.

Niemann, H., and H. Behling. 2008. Late Quaternary vegetation, climate and fire dynamics inferred from the El Tiro record in the southeastern Ecuadorian Andes. Journal of Quaternary Science 23:203-212.

Niemann, H., and H. Behling. 2009a. Late Pleistocene and Holocene environmental change inferred from the Cocha Caranga sediment and soil records in the southeastern Ecuadorian Andes. Palaeogeography, Palaeoclimatology, Palaeoecology 276:1-14.

Niemann, H., and H. Behling. 2009b. Late Holocene environmental change and human impact inferred from three soil monoliths and the Laguna Zurita multi-proxi record in the southeastern Ecuadorian Andes. Vegetation History and Archaeobotany 19:1-15.

Niemann, H., C. Brunschön, and H. Behling. 2010. Vegetation/modern pollen rain relationship along an altitudinal transect between 1920 and 3185ma.s.I. in the Podocarpus National Park region, southeastern Ecuadorian Andes. Review of Palaeobotany and Palynology 159:69-80. 
Niemann, H., T. Haberzettl, and H. Behling. 2009. Holocene climate variability and vegetation dynamics inferred from the (11700 cal. yr BP) Laguna Rabadilla de Vaca sediment record, southeastern Ecuadorian Andes. The Holocene 19:307-316.

Olivera, M., J. Duivenvoorden, and H. Hooghiemstra. 2009. Pollen rain and pollen representation across a forest-páramo ecotone in northern Ecuador. Review of Palaeobotany and Palynology 157:285-300.

Ortuño, T., M.-P. Ledru, R. Cheddadi, A. Kuentz, C. Favier, and S. Beck. 2011. Modern pollen rain, vegetation and climate in Bolivian ecoregions. Review of Palaeobotany and Palynology 165:61-74.

Paduano, G., M. Bush, P. Baker, S. Fritz, and G. Seltzer. 2003. A vegetation and fire history of Lake Titicaca since the Last Glacial Maximum. Palaeogeography, Palaeoclimatology, Palaeoecology 194:259-279.

Parsons, R., and I. Prentice. 1981. Statistical approaches to R-values and the pollen - vegetation relationship. Review of Palaeobotany and Palynology 32:127-152.

Piperno, D., and K. Stothert. 2003. Phytolith Evidence for Early Holocene Cucurbita Domestication in Southwest Ecuador. Science 299:1054-1057.

Podwojewski, P., J. Poulenard, T. Zambrana, and R. Hofstede. 2006. Overgrazing effects on vegetation cover and properties of volcanic ash soil in the páramo of Llangahua and La Esperanza (Tungurahua, Ecuador). Soil Use and Management 18:45-55.

Prentice, I. C. 1985. Pollen representation, source area, and basin size: Toward a unified theory of pollen analysis. Quaternary Research 23:76-86.

Ramsay, P., and E. Oxley. 1997. The growth form composition of plant communities in the ecuadorian páramos. Plant Ecology 131:173-192.

Rangel-Ch., J. 2005. Lluvia de polen a lo largo de los transectos del macizo del Tatamá. Pages 711755 La Cordillera Occidental colombiana- Transecto de Tatamá. Cramer/Bornträger, Berlin-Stuttgart.

Reese, C., and L. Kam-Biu. 2005. A modern pollen rain study from the central Andes region of South America. Journal of Biogeography 32:709-718.

Richter, M., K.-H. Diertl, P. Emck, T. Peters, and E. Beck. 2009. Reasons for an outstanding plant diversity in the tropical Andes of Southern Ecuador. Landscape Online 12:1-35.

Richter, M., K.-H. Diertl, T. Peters, and R. Bussmann. 2008. Vegetation Structures and Ecological Features of the Upper Timberline Econtone. Pages 123-136 in E. Beck, J. Bendix, I. Kottke, F. Makeschin, and R. Mosandl, editors. Gradients in a tropical mountain ecosystem of Ecuador. Springer, Berlin.

Rollenbeck, R., and J. Bendix. 2011. Rainfall distribution in the Andes of southern Ecuador derived from blending weather radar data and meteorological field observations. Atmospheric Research 99:277-289.

Rodríguez, F., and H. Behling. 2010. Late Holocene vegetation, fire, climate and upper forest line dynamics in the Podocarpus National Park, southeastern Ecuador. Vegetation History and Archaeobotany20:1-14.

Rull, V. 2006. A high mountain pollen-altitude calibration set for palaeoclimatic use in the tropical Andes. The Holocene 16:105-117.

Rull, V., M. Abbott, P. Polissar, A. Wolfe, M. Bezada, and R. Bradley. 2005. 15,000-yr pollen record of vegetation change in the high altitude tropical Andes at Laguna Verde Alta, Venezuela?. Quaternary Research 64:308-317.

Salgado-Labouriau, M. 1979. Modern pollen deposition in the Venezuelan Andes. Grana 18:53-68.

Temme, M. (1982). Excavaciones en el sitio precerámico de Cubilan (Ecuador). Miscelánea Antropológica Ecuatoriana 2:135-165.

Urrego, D., B. Niccum, C. La Drew, M. Silman, and M. Bush. 2011a. Fire and drought as drivers of early Holocene tree line changes in the Peruvian Andes. Journal of Quaternary Science 26:28-36. 
Urrego, D., M. Silman, A. Correa-Metrio, and M. Bush. 2011b. Pollen-vegetation relationships along steep climatic gradients in western Amazonia. Journal of Vegetation Science:795806.

Valdez, F. 2008. Inter-zonal relationships in Ecuador. Pages 865-888 in H. Silverman and W. Isbell, editors. Handbook of South American Archeology. Springer.

Valencia, B., D. Urrego, M. Silman, and M. Bush. 2010. From ice age to modern: a record of landscape change in an Andean cloud forest. Journal of Biogeography 37:1637-1647.

Velez, M., H. Hooghiemstra, S. Metcalfe, M. Wille, and J. Berrio. 2006. Late Glacial and Holocene environmental and climatic changes from a limnological transect through Colombia, northern South America. Palaeogeography, Palaeoclimatology, Palaeoecology 234:81-96.

Villota, A., S. León-Yánez, and H. Behling. 2012. Vegetation and environmental dynamics in the Páramo of Jimbura region in the southeastern Ecuadorian Andes during the late Quaternary. Journal of South American Earth Sciences 40:85-93.

Weigend, M. 2002. Observations on the Biogeography of the Amotape-Huancabamba Zone in Northern Peru. The Botanical Review 68:38-54.

Weng, C., M. Bush, J. Curtis, A. Kolata, T. Dillehay, and M. Binford. 2006. Deglaciation and Holocene climate change in the western Peruvian Andes. Quaternary Research 66:87-96.

Weng, C., M. Bush, and M. Silman. 2004. An analysis of modern pollen rain on an elevational gradient in southern Peru. Journal of Tropical Ecology 20:113-124.

Wille, M., H. Hooghiemstra, R. Hofstede, J. Fehse, and J. Sevink. 2002. Upper forest line reconstruction in a deforested area in northern Ecuador based on pollen and vegetation analysis. Journal of Tropical Ecology 18: 409-440.

Willis, K., L. Gillson, and S. Knapp. 2007. Biodiversity hotspots through time: an introduction. Philosophical Transactions of the Royal Society B: Biological Sciences 362:169-174.

Witte, H. 1994. Present and past vegetation and climate in the Northern Andes (Cordillera Central, Colombia): A quantitative approach. PhD thesis, University of Amsterdam.

Wolf, K., E. Veldkamp, J. Homeier, and G. Martinson. 2011. Nitrogen availability links forest productivity, soil nitrous oxide and nitric oxide fluxes of a tropical montane forest in southern Ecuador. Global Biogeochemical Cycles 25:4009. 


\section{CHAPTER 2}

A Holocene environmental record reflecting

vegetation, climate, and fire variability at the Páramo

of Quimsacocha, southwestern Ecuadorian Andes

Nele Jantz ${ }^{1} \&$ Hermann Behling ${ }^{1}$

${ }^{1}$ Department of Palynology and Climate Dynamics, Albrecht-von-Haller Institute for Plant

Sciences, University of Göttingen, 37073 Göttingen, Germany

Vegetation History and Archaeobotany 21 (2012) 169-185,

Doi: 10.1007/s00334-011-0327-x 


\begin{abstract}
We reconstructed the palaeoenvironmental conditions of the last ca. 8000 years in the Tres Lagunas region of the Quimsacocha volcanic basin (ca. $3800 \mathrm{~m}$ a.s.I.) in the southwestern Ecuadorian Andes. By means of a pollen and charcoal record, we analysed vegetation, fire, and climate history of this area, which is sensitive to climatic changes of both the Pacific as well as of the eastern Andes and Amazon region. Sediment deposits, pronounced increases of pollen and charcoal concentrations, and pollen taxa reflect warmer and drier conditions in the early to midHolocene ( 8000 to 3900 cal. yr BP). During the late Holocene (2250 to -57 cal. yr BP), five warm and cold phases occurred at Quimsacocha. The most prominent cold phase possibly corresponds to the globally recognized Little Ice Age (LIA; 600 to 100 cal. yr BP). The cold phase signal at Quimsacocha was characterized by a higher abundance of Poaceae, Isoëtes and Gentianella, which are favoured by cold and moist conditions. Frequent charcoal particles can be recorded since the early to mid-Holocene ( 7600 B.P.). The high Andean tree species Polylepis underwent several phases of degradation and re-establishment in the basin, which could indicate the use of fire by pre-Columbian settlers to enhance the growth of preferred herb species. The Tres Lagunas record suggests that human populations have been influencing the environment around Quimsacocha since the last ca. 8000 years.
\end{abstract}

\title{
Keywords
}

Palaeoecology, Holocene, Climate change, Páramo, Andes, Ecuador

\subsection{Introduction}

The Ecuadorian Andes are important: (i) Ecologically because of high diversity (both alpha and beta) and endemism (Balslev andLuteyn 1992; Jørgensen and León-Yánez 1999; Luteyn 1999) and (ii) for the provision of ecosystem-services, such as the regulation of Andean hydrology, protection from erosion and the provision of food for a growing population. However, the landscapes of the Ecuadorian Andes suffer a high degradation rate. Ecuador has the highest deforestation rate in South America (Mosandl et al. 2008; Sarmiento 2002), and Páramo areas especially of lower altitudes are subject to overgrazing, fire or cultivation, which lead to reduction of biodiversity and water retention capacity, as well as to soil erosion (Podwojewski et al. 2002). The development of useful and innovative protection strategies in the Ecuadorian Andes is consequently urgently needed. In this context, the knowledge of palaeoecological conditions can be of crucial importance, as the composition of past natural as well as of pre-Columbian 
anthropogenic landscapes and climate conditions are often not well known. Several palaeoecological studies have been carried out in the eastern tropical Andes (e.g. Brunschön et al. 2010; Hillyer et al. 2009; Niemann and Behling 2008), whereas there are only a few studies that deal with the conditions on the western Cordillera (e.g. Colinvaux et al. 1997; Hansen et al. 2003; Weng et al. 2006). In general, there is a trend of a warm and dry early to mid-Holocene in the west and central Andes region of Ecuador, Peru and Bolivia (Hansen et al. 2003; Paduano et al. 2003; Weng et al. 2006). However, there are still uncertainties concerning the magnitude and time span of this mid-Holocene dry event. A time-transgressive reoccurrence of moister conditions from north to south seems to be evident for the Central Andes region of Peru and Bolivia. A longer and more severe dry phase from 6000 to 2400 cal. yr BP is reported from central Bolivia (Taypi Chaka Kkota, $16^{\circ} \mathrm{S}$, Abbott et al. 2003), whereas sediments from Laguna la Compuerta $\left(7^{\circ} \mathrm{S}\right)$ in northern Peru show a shorter dry phase from 10,000 to $5500 \mathrm{cal}$. yr BP (Weng et al. 2006). In some parts of the southern tropical Andes region, the mid-Holocene dry event does not seem to be as pronounced and some palaeorecords show volatile lake levels rather than a complete drying-out, as for example Hillyer et al. 2009 and Valencia et al. 2010 for Laguna Pacucha in Southern Peru ( $13^{\circ} \mathrm{S}, 3,095 \mathrm{~m}$ a.s.l.). To what extend the western cordillera of the Ecuadorian Andes was subjected to the mid-Holocene dry event remains yet to be determined due to an absence of published studies. The late Holocene is marked as a moister period with repeated climatic oscillations for most tropical Andean sites, such as Lake Titicaca and Taypi Chaka Kkota in Bolivia (Abbott et al. 2003). During this period, human influence is reported throughout the Andes. Weng et al. (2006) date human influence back to least 5500 cal. yr BP for Laguna Compuerta in northern Peru and Bush et al. (2005) suggest occasional human influence from 6000 cal. yr BP at Laguna de Chochos, about $200 \mathrm{~km}$ northeast of Laguna Compuerta. In the southwestern Ecuadorian Andes, traces of human land use are present in the pollen records of Laguna Pallcacocha and Lagunas Chorreras since $\sim 4000$ cal. yr BP (Hansen et al. 2003). In this paper, we present results of palaeoecological investigations from the Tres Lagunas region in the Quimsacocha volcanic basin in south Ecuador, which, due to its situation on the eastern ridge of the western Cordillera, is sensitive to climatic changes of both the Pacific as well as of the eastern Andes and Amazon region. Our main objective is to detect climatic patterns of regional to global significance since the early to mid-Holocene. We will assess the role of the mid-Holocene dry phase, as well as late Holocene climatic patterns for this part of the tropical Andes region. Furthermore, we will integrate our results into a more regional comparison of records. We will also reconstruct regional vegetation and fire dynamics and assess the history of anthropogenic impact of the Quimsacocha volcanic basin. 


\subsubsection{Study region}

\section{Geomorphology}

The regional geomorphology was shaped by glacial activity, persisting until the late Pleistocene ( 12,6000-11,800 B.P.). Characteristic features include U-shaped valleys, numerous small lakes, and moraines (Rodbell 2002; Hansen et al. 2003). Even though a few studies on past vegetation (Colinvaux et al. 1997; Hansen et al. 2003) and soils (Rodbell 2002; Harden 2007) have been carried out in the nearby Cajas National park area and surroundings, no absolute dates for the glacial retreat have been determined so far. However, by the means of pollen and sediment analyses, a glacial retreat has been recorded for the period between 17,000 and 15,000 cal. yr BP at the lakes Laguna Llaviucu (3140 m a.s.l.), Laguna Chorreras (3700 m a.s.I.) and Laguna Pallcacocha (4060 m a.s.l.) (Hansen et al. 2003; Colinvaux et al. 1997).

\section{Potentially natural forest vegetation and land use}

Three major forest types have been recognised in the Podocarpus National Park today (about 200 $\mathrm{km}$ south of the study site) (Homeier et al. 2008). The evergreen lower mountain rainforest is found at altitudes from 1300 to $2100 \mathrm{~m}$ a.s.l. Here, trees grow up to $40 \mathrm{~m}$ in height and form dense vegetation that is enriched with many epiphytes and lianas. Typical plant families and genera are Arecaceae, Bignoniaceae (Tabebuia), Clusiaceae (Vismia), Lauraceae (Nectandra and Ocotea), Melastomataceae (Miconia), Moraceae (Ficus, Morus) and Piperaceae (Piper).

From ca. 2100-2700 $\mathrm{m}$ a.s.l. evergreen upper mountain rainforest grows on the more humid Andean slopes. Canopies reach a maximum height of about $25 \mathrm{~m}$ in this vegetation type and abundant taxa include Aquifoliaceae (Ilex), Chloranthaceae (Hedyosmum), Clethraceae (Clethra, Purdiaea), Cunoniaceae (Weinmannia), Cyatheaceae (Cyathea), Myricaceae (Myrica), Myrsinaceae (Myrsine) and Podocarpaceae (Podocarpus, Prumnopitys).

The Subpáramo, or elfin forest, forms the forestline ecotone with trees and shrubs of $8 \mathrm{~m}$ height at maximum. Characteristic taxa are Aquifoliaceae (Ilex), Bromeliaceae (Puya), Chloranthaceae (Hedyosmum), Cunoniaceae (Weinmannia), Clethraceae (Clethra), Loranthaceae (Gaiadendron), Ericaceae (Gaultheria), Melastomataceae (Graffenrieda) and Symplocaceae (Symplocos), as well as dense stands of the bamboo Chusquea (Poaceae).

In general, human activity has a big impact on the vegetation of the Andes in Ecuador, as land use patterns frequently involve grazing, burning and deforestation (Ramsay and Oxley 1996). 


\section{Regional climate}

The climate of the study region is humid, tropical and montane, with strong winds and occasional frost. Climatic patterns are mostly controlled by the tropical trade wind regime with its easterlies carrying moisture from the Amazon basin, but local wind patterns are considerably modified by the topography of the Andes (Beck et al. 2008; Emck 2007). Because of the height reduction of the mountain chain and associated barrage effects of the Amazon trade winds, cloud frequency in the Andean depression is generally high at about 70-75\%, and a persistent fog belt below $3600 \mathrm{~m}$ adds to precipitation (Bendix et al. 2004; Hansen et al. 2003).

Palaeoecological records from Lagunas Pallcacocha in the Cajas National Park, which is situated $50 \mathrm{~km}$ further north, but also on the eastern side of the western Cordillera, report the influence of El Niño Southern Oscillation on the site (Moy et al. 2002).

\subsubsection{Study site}

\section{Location}

The study area Tres Lagunas $\left(03^{\circ} 02^{\prime} \mathrm{S}\right.$, $79^{\circ} 14^{\prime} \mathrm{W}$ ) is located on the Quimsacocha volcanic plateau on the eastern ridge of the western Cordillera of the Andes in south Ecuador (Fig. 1). Situated about 30 $\mathrm{km}$ southwest of the city of Cuenca, it is thus close to the big Cajas massif.

This region comprises the northernmost part of the Andean depression between Girón-Cuenca in south Ecuador and Huancabamba in north Peru. Here, mountains barely reach heights of $4000 \mathrm{~m}$ and no active volcanoes are present.
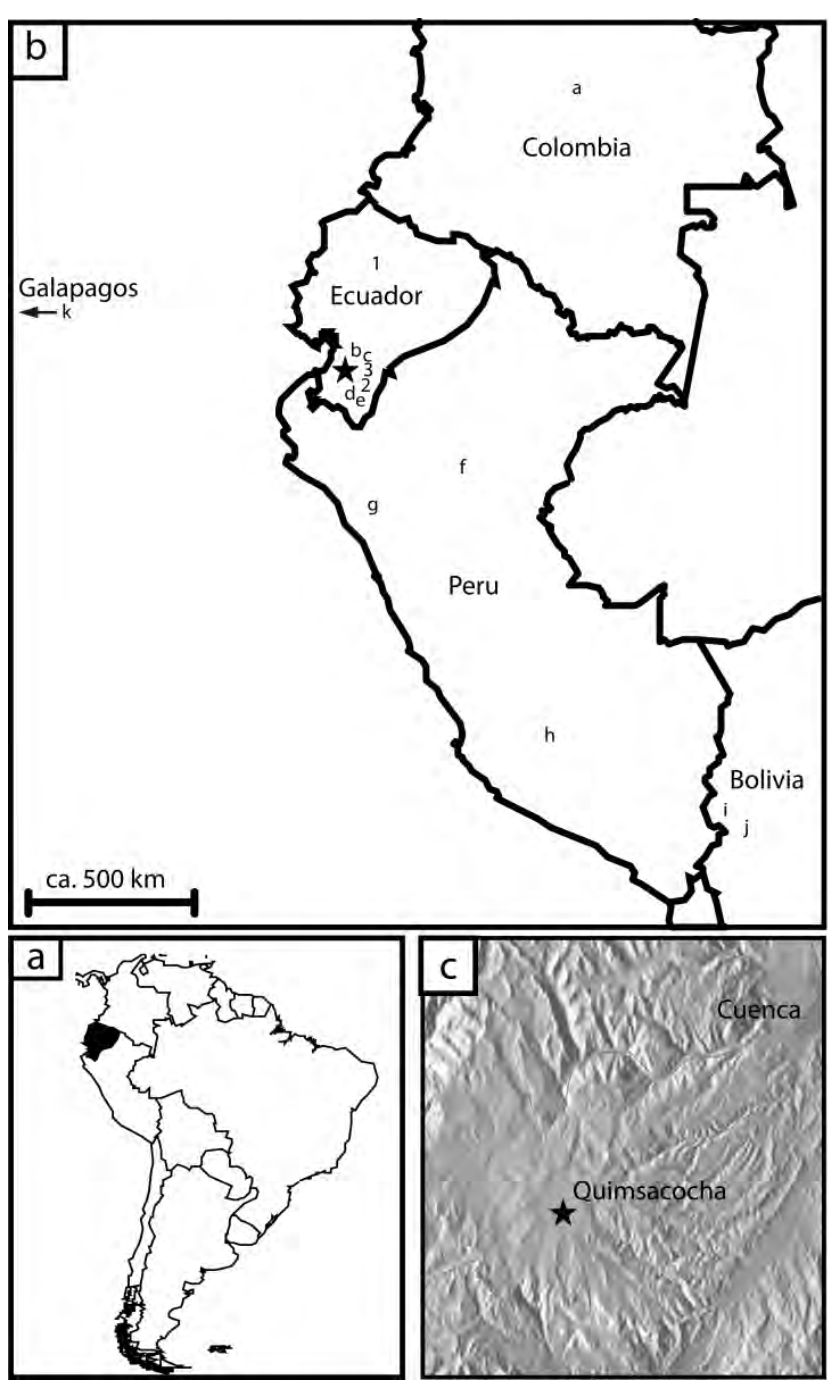

Figure 3 a Map of Ecuador in South America. b Map of Ecuador, Colombia, Peru and Bolivia with sites mentioned in the text. Paleoecological records: star study site Tres Lagunas, $a$ Turbera de Calostros, $b$ Lagunas Correras, $c$ Laguna Pallcacocha, $d$ El Tiro, $e$ Cerro Toledo, $f$ Laguna de Chochos, $g$ Laguna la Compuerta, $h$ Laguna Pacucha, $i$ Laguna Titicaca, $j$ Taypi Chaka Kkota, $k$ Laguna el Junco (Galapagos). Archaeological sites: 1 El Inga, 2 Cubilan, 3 Chobshi cave. c Map of Cuenca and the Tres Lagunas region in the Quimsacocha volcanic basin. Source: Planiglobe Beta (www. planiglobe.com, Creative Commons Attribution 2.5 License).

The core Tres Lagunas (TL) was taken from 
the shallow old volcanic basin Quimsacocha, which has a circular surface of ca. $8 \mathrm{~km}^{-2}$ and is situated at an altitude of $3780 \mathrm{~m}$ a.s.l.

\section{Geology}

The superficial rocks in the Quimsacocha region are of volcanic origin. At the TL site, the activity of the Quimsacocha volcano led to the Tarqui-formation which was formed during the late Miocene to Plio-Pleistocene and contains various lithologies, such as ashflow tuffs, rhyolithic to andesitic volcanic breccias, pyroclastic flows and ignimbrites. Intermediate to acid pyroclastics have partly converted to dark red and purple kaolinitic clays in the upper part of the formation (Hungerbühler et al. 2002).

\section{Soils}

The most important soil types of the Páramo are Andosols and Histosols, defined by the content of volcanic ashes in the soil. Both soil types are generally characterised by dark epipedons which contain high amounts of organic material and have a loose granular to subangular blocky structure with a very low bulk density $\left(400 \mathrm{~kg} \mathrm{~m}^{-3}\right)$. Furthermore, the soils are marked by a very high water retention capacity with values of up to more than $100 \%$ (Buytaert et al. 2005).

\section{Modern climate}

The mean annual rainfall in the Quimsacocha region is $1280 \mathrm{~mm}$, but precipitation shows high seasonal variability. The most humid months are November, March and April with a precipitation of about 250-280 mm, whereas in the driest months of August and December the precipitation is very low at about $20 \mathrm{~mm}$ (AMBIGEST 2005). Temperatures vary on a diurnal basis between 12 and $19^{\circ} \mathrm{C}$ during the day and 2 to $-3^{\circ} \mathrm{C}$ at night. The prevailing winds (59\%) are from the northeast with wind speeds from 3 to $5.1 \mathrm{~m} / \mathrm{s}$ (AMBIGEST 2005).

\section{Modern vegetation and land use}

The vegetation surrounding the study site is Páramo, which is typically dominated by tussock plants, along with acaulescent rosettes, erect and prostrate herbs (Ramsay and Oxley

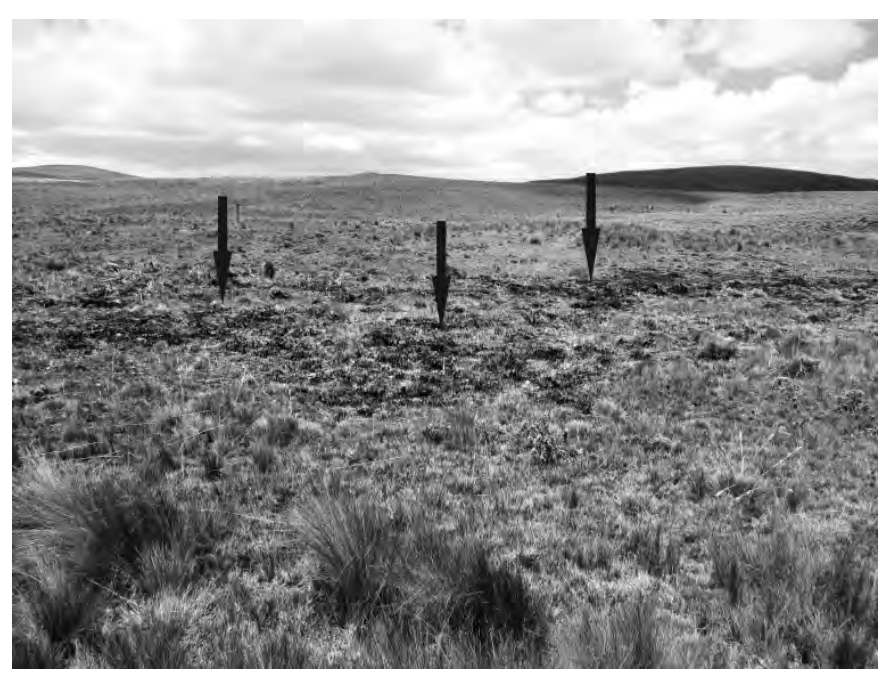

Figure 4 Photograph of the Quimsacocha volcanic basin with arrows marking the traces of recent fire activity. 
1997). The tussock Páramo at this site is dominated by bunch-grasses of the genera Stipa and Calamagrostis (both Poaceae). Other recorded abundant genera with various species include Hypericaceae (Hypericum), Poaceae (Paspalum, Cortaderia), Valerianaceae (Valeriana), Asteraceae (Baccharis, Chuquiraga, Gynoxys, Diplostephium, Werneria, Loricaria), Apiaceae (Eryngium, Hydrocotyle), Gentianaceae (Gentianella, Halenia), Geraniaceae (Geranium), Lycopodiaceae (Huperzia), Pteridaceae (Jamesonia), Fabaceae (Lupinus), Campanulaceae (Lysipomia) and Bromeliaceae (Puya) (AMBIGEST 2005; personal observation). Cushion forming Plantaginaceae (mostly Plantago rigida) and Cyperaceae (Uncinia) are typically found in moist depressions of higher elevated Páramo sites (Bosman et al. 1994).

The vegetation of the study site is strongly influenced by the topography of the Andes and the resulting environmental conditions, such as the strong variability of rainfall, wind and temperature. The whole Quimsacocha basin is used as pasture for llamas and alpacas and surface fires are often used by the local farmers to remove unwanted vegetation such as tufts of Calamagrostis (personal observation, Fig. 2).

On lower elevation Páramo sites, vast areas of exotic tree plantations with Pinus spp. and Eucalyptus spp. have been established over the past decades and are now a prominent feature of the Andean landscape (Hofstede et al. 2002; Farley 2007; Sarmiento 2002). Besides this, the fastgrowing Peruvian high-altitude species Polylepis racemosa has been introduced and planted in the Páramos of Quimsacocha.

\subsection{Methods}

\subsubsection{Coring and dating}

A sediment core $144 \mathrm{~cm}$ in length was taken with a Russian corer in a peat bog at the TresLagunas site in September 2007 (surface sample, -57 yr B.P.). Three sections $50 \mathrm{~cm}$ long were stored in PVC tubes. The core was kept under dark and cold $\left(+4^{\circ} \mathrm{C}\right)$ conditions at the Department of Palynology and Climate Dynamics at the University of Göttingen (Germany) before processing. Six samples of organic material were taken for Accelerator Mass Spectrometry (AMS) radiocarbon dating and sent to the University of Erlangen-Nürnberg and to the Poznan Radiocarbon Laboratory. Sample ages were calibrated using Calpal online and the Calpal 2007 HULU curve for the Northern Hemisphere (Weninger et al. 2010). Sedimentation rates were calculated for each interval between two calibrated radiocarbon datings (except for the outlier). The surface was set to be of an age of -57 B.P. To show the greatest differences possible for the given dates, we calculated minimum, average and maximum sedimentation rates. For the maximum rate, the 
estimated minimum of the earlier date and the estimated maximum of the later date were taken, for the average rate the estimated average dates were taken, and for the minimum sediment accumulation rate the estimated maximum of the earlier date as well as the estimated minimum of the later date were used for analysis.

\subsubsection{Sample processing and analysis}

For the extraction of pollen, spores and charcoal, 58 subsamples with a volume of $0.25 \mathrm{~cm}^{-3}$ sediment were taken from the core at distances of $2 \mathrm{~cm}$ apart, from the surface $(0 \mathrm{~cm})$ down to $142 \mathrm{~cm}$. Processing was carried out using standard pollen analytical methods, modified from Fægri and Iversen (1989). One tablet of Lycopodium clavatum, containing 18,583 \pm 762 spores, was added to each subsample to enable the calculation of pollen concentration. Samples were generally counted to a minimum of 300 pollen grains. The pollen sum excludes ferns and mosses, including Isoëtes, as well as undetermined taxa. For one sample $(114 \mathrm{~cm})$, grains could only be counted up to a total number of 100 due to very low pollen concentration. Below $114 \mathrm{~cm}$ core depth, samples were not analysed, because pollen concentration was very low and preservation of the grains was not sufficient. For the determination of pollen and spore taxa, the reference collections of Ecuador (containing ca. 400 taxa) and Brazil (containing ca. 3000 taxa) of the Department of Palynology and Climate Dynamics, University of Göttingen, were used. Support for determination was also given by the electronic pollen keys of Ecuador and southern Brazil kept at the department, as well as by the Southern American Pollen Database (Bush and Weng 2007) and by literature (Hooghiemstra 1984; Roubik and Moreno 1991). All pollen types were attributed to groups that either correspond to different vegetational units (Lower Mountain Rainforest, Upper Mountain Rainforest, Subpáramo, Páramo) or had to be grouped due to lack of information or by correspondence to other groups (others, ferns and mosses as well as unknown and indeterminate taxa). A full list of the taxa groupings can be found in Table 1.

For charcoal analysis, a traverse of the middle of the slide was made and charcoal particles and markers were counted up to a total of 100 Lycopodium clavatum spores to ensure a charcoal concentration estimate with an error of less than $5 \%$ (Finsinger et al. 2008). In samples with a very high pollen concentration (Sample numbers 52-57, 102-112 cm), charcoal was only counted up to a total count of ten markers and then multiplied by ten. Furthermore, the counted charcoal particles were attributed to one of five groups of different particle sizes so as to give more detailed evidence about the fire history in terms of distance of fires from the study site (Whitlock and Larsen 2001; Sadori and Giardini 2007). Therefore groups of particle sizes from 10-25 $\mu \mathrm{m}$, 
25-50 $\mu \mathrm{m}, 50-100 \mu \mathrm{m}$ and $>100 \mu \mathrm{m}$ were created. Charcoal particles were measured taking their longest axis (Whitlock and Larsen 2001).

\subsubsection{Data analysis}

By means of the program TILIA (Grimm 1987), taxa were placed in the groups mentioned above. Sums, percentages, and pollen and charcoal concentration (grains, respectively particles $\mathrm{cm}^{-3}$ ), were then calculated with the same program. The results were depictured using TILIAGRAPH, and pollen zones were created by means of the program CONISS based on a cluster analysis using the total sum of squares (Grimm 1987). Only the pollen grains that contributed to the total pollen sum of 300 were included in this analysis, as this gave the best fit with stratigraphy. Multivariate data analysis was carried out on pollen percentage data using the programmes Canoco for Windows 4.5 and CanoDraw for Windows 4.13 (ter Braak and Šmilauer 2002). All pollen taxa which were present in at least 2 samples in one of which a percentage value of $>1 \%$ was reached were included in the analysis to decrease the effect of rare taxa that do not explain the overall vegetation trend well. First, a detrended correspondence analysis (DCA) was conducted to determine the length of the environmental gradient, which had a value of only 1.305 . Thus a linear model could explain and depict the data in a more comprehensive way. We therefore carried out a principal components analysis (PCA). For both analyses, data were transformed using square-root transformation. This removes the emphasis from very dominant taxa and improves the fit of the count data.

\subsection{Results}

\subsubsection{Stratigraphy}

The stratigraphy of the sediment is shown in Fig. 4b. From the bottom of the core at $130 \mathrm{~cm}$ up to a depth of $111.5 \mathrm{~cm}$, almost no organic matter is present in the sediment. Silty clay and sand particles dominate this part of the core which has a greyish colour with light brown bands. From 111.5 to $98 \mathrm{~cm}$, the sediment becomes a much more compact and decomposed dark brown peat. From 98 to $23 \mathrm{~cm}$ the main component of the sediment is decomposed, peaty organic material, yet few plant remains are visible. From a depth of $23 \mathrm{~cm}$ to the surface, the sediment consists of poorly decomposed brownish plant material. 


\subsubsection{Chronology and pollen zonation}

Five radiocarbon dates were used to create a chronology for the Tres Lagunas core (Table 2). Dating was based on organic material (peat), which was cleaned from roots and rootlets. The assumption that the surface is modern could be verified by pollen analysis, as pollen of the exotic genus Pinus was found in the uppermost sample. The base of the core dates back to the early Holocene with an age of $8428 \pm 41 \mathrm{cal}$. yr BP at $141 \mathrm{~cm}$ depth. However, the base of the section analysed $(114 \mathrm{~cm})$ is of an age of approximately $7750 \mathrm{cal}$. yr BP.The age-depth relationship of the core is consistent with the exception of one outlier at $48-48.5 \mathrm{~cm}$ core depth, which is dated as $144 \pm 50$ cal. yr BP. This radiocarbon age was disregarded for the construction of the age depth model because of its incompatibility with the other age data obtained (Table 2); we interpret the anomalously young age of the $48.5 \mathrm{~cm}$ sample as a product of root activity moving young carbon down through the stratigraphy. Sedimentation rates were not constant through time (Fig. 3), but for most of the core they stay in the range from 1.9 to $6.2 \mathrm{~mm}$ year $^{-1}$. However, sediment accumulation decreases by an order of magnitude from 98.5 to $110.5 \mathrm{~cm}$ to very low rates of 0.22 $\mathrm{mm}$ year $^{-1}$. Therefore, we take into account a hiatus from $7672 \pm 37$ cal. yr BP to $2242 \pm 66$ cal. yr $B P$, which is supported by an abrupt change of the sediment structure (see grey bars indicated in Figs. 3 and 4). The cluster analysis helped to determine six pollen zone divisions, including one subdivision (Fig. 4b).

\subsubsection{Pollen zone description}

Zone TL-I (114-97 cm; 9 samples, 7800-2250 cal. yr BP)

The later part of the early Holocene and the whole mid-Holocene are represented here. Thus, this zone is characterised by mostly very high pollen concentration values of up to 4,380,000 grains $\mathrm{cm}^{-3}$ which correlate with sedimentation rates of $0.02 \mathrm{~mm}$ year ${ }^{-1}$. Also, the highest charcoal concentration values are reached in this zone. The pollen composition of this zone is different to that throughout the upper parts of the core, with relatively high values of Plantago rigida type (17-10\%) and Apiaceae (2-7\%), as well as the presence of Valeriana, Gentianella type, Baccharis type and Lysipomia (all 2-4\% at maximum) at the bottom of the zone. Although Poaceae (29$48 \%$ ) is the most abundant pollen taxon, a high varietyof other taxa, such as Lamiaceae (0-6\%), Lupinus type (0-21\%), Ranunculus type (0-12\%), Senecio type (0-3\%) and Hydrocotyle type (0$5 \%)$ account for the composition of the diversity. Fern spores show highest values at the bottom of this zone, mostly due to Huperzia (9-3\%), while values of Isoëtes reach $11 \%$ at the top of the zone. 
Table 1 List of fully identified pollen and spore taxa from the Tres Lagunas sediment core

\begin{tabular}{|c|c|c|c|c|c|c|c|}
\hline \multicolumn{2}{|c|}{ Páramo } & Subpáramo & $\begin{array}{l}\text { Upper mountain } \\
\text { forest (UMF) }\end{array}$ & $\begin{array}{c}\text { Lower mountain } \\
\text { forest (LMF) }\end{array}$ & Others & Pteridophyta & Mosses \\
\hline $\begin{array}{l}\text { - Sagittaria/Echinodorus } \\
\text { type } \\
\text { - Hydrocotyle type } \\
\text { - Apiaceae } \\
\text { - Eryngium type } \\
\text { - Ambrosia type } \\
\text { - Asteraceae others } \\
\text { - Subf. Cichorioidae } \\
\text { - Asteraceae type } 1 \\
\text { - Baccharis type } \\
\text { - Senecio type } \\
\text { - Vernonia type } \\
\text { - Begonia type } \\
\text { - Brassicaceae } \\
\text { - Lysipomia } \\
\text { - Caryophyllaceae } \\
\text { - Convolvulaceae } \\
\text { - Cyperaceae }\end{array}$ & $\begin{array}{l}\text { - Ericaceae } \\
\text { - Eriocaulon type } \\
\text { - Lupinus - type } \\
\text { - Fabaceae } \\
\text { - Gentianaceae } \\
\text { - Gentianella type } \\
\text { - Macrocarpaea type } \\
\text { - Geranium } \\
\text { - Hypericum } \\
\text { - Iridaceae } \\
\text { - Lamiaceae } \\
\text { - Liliaceae type } \\
\text { - Plantago australis } \\
\text { type } \\
\text { - Plantago rigida type } \\
\text { - Poaceae } \\
\text { - Polygala type } \\
\text { - Polygonum }\end{array}$ & $\begin{array}{l}\text { - Bomarea } \\
\text { - Oreopanax } \\
\text { - Clethra } \\
\text { - Gunnera } \\
\text { - Gaiadendron type } \\
\text { - Melastomataceae } \\
\text { - Myrteola type } \\
\text { - Muehlenbeckia type } \\
\text { - Polylepis/Acaena } \\
\text { type }\end{array}$ & $\begin{array}{l}\text { - Ilex } \\
\text { - Alnus } \\
\text { - Hedyosmum } \\
\text { - Weinmannia } \\
\text { - Elaeocarpaceae } \\
\text { cf. Vallea } \\
\text { - Myrica } \\
\text { - Myrsine } \\
\text { - Myrtaceae type } \\
\text { - Bocconia } \\
\text { integrifolia type } \\
\text { - Podocarpaceae } \\
\text { - Dodonaea }\end{array}$ & $\begin{array}{l}\text { - Cecropia } \\
\text { - Acalypha } \\
\text { - Alchornea } \\
\text { - Mimosaceae } \\
\text { - Moraceae/Urticaceae } \\
\text { - Ouratea type } \\
\text { - Piper } \\
\text { - Psychotria type } \\
\text { - Solanum type } \\
\text { - Celtis }\end{array}$ & $\begin{array}{l}\text { - Amaranthaceae/ } \\
\text { Chenopodiaceae } \\
\text { - Deeringia-Morphotype } \\
\text { - Schinus type } \\
\text { - Euphorbiaceae } \\
\text { - Juglans } \\
\text { - Orchidaceae } \\
\text { - Pinus } \\
\text { - Zea mays } \\
\text { - Byttneria- type }\end{array}$ & $\begin{array}{l}\text { - Blechnum type } \\
\text { - Cyathea } \\
\text { - Dicksonia sellowiana } \\
\text { - Hymenophyllum type } \\
\text { - Lophosoria } \\
\text { quadripinnata } \\
\text { - Huperzia type } 1 \\
\text { - Lycopodium } \\
\text { alupecuroides type } \\
\text { - Lycopodium } \\
\text { curvatum type } \\
\text { - Lycopodium type } 1 \\
\text { - Ophioglossum } \\
\text { - Osmunda type } \\
\text { - Grammitis } \\
\text { - Lellingeria type } \\
\text { - Pteris type } \\
\text { - Selaginella anceps } \\
\text { type } \\
\text { - Selaginella type } 1 \\
\text { - Isoëtes }\end{array}$ & $\begin{array}{l}\text { - Anthoceros } \\
\text { - Phaeoceros } \\
\text { - Sphagnum }\end{array}$ \\
\hline
\end{tabular}


Table 2 AMS Radiocarbon dates, calibrations, sediment accumulation rates and type of material used for dating of samples from the Tres Lagunas sediment core

\begin{tabular}{|c|c|c|c|c|c|c|}
\hline Lab. no. & $\begin{array}{l}\text { Depth } \\
(\mathrm{cm})\end{array}$ & $\begin{array}{l}{ }^{14} \mathrm{C} \text { age } \\
\text { (yr BP) }\end{array}$ & $\begin{array}{l}\text { Calibrated } \\
\text { age } \\
(\text { cal yr BP) }\end{array}$ & $\begin{array}{l}\text { 1- } \sigma \text { range } \\
\text { (cal a } \mathrm{BP})\end{array}$ & $\begin{array}{l}\text { Sediment } \\
\text { accumulation } \\
\text { rates (min-max) } \\
{[\mathrm{mm} / \mathrm{yr}]}\end{array}$ & Type of material dated \\
\hline Erl- $13827^{b}$ & $48-48.5$ & $-144 \pm 50$ & -- & -- & - & $\begin{array}{l}\text { Decomposed organic material } \\
\text { with rootlets }\end{array}$ \\
\hline Erl- 12178 & $70-70.5$ & $1143 \pm 41$ & $1063 \pm 63$ & $1000-1126$ & $0.63-0.71$ & $\begin{array}{l}\text { Peaty, strongly decomposed } \\
\text { material }\end{array}$ \\
\hline Erl- 12487 & $90-90.5$ & $2125 \pm 41$ & $2118 \pm 70$ & $2048-2188$ & $0.17-0.22$ & $\begin{array}{l}\text { Peaty, strongly decomposed } \\
\text { material }\end{array}$ \\
\hline Erl- 13828 & $98.5-99$ & $2224 \pm 45$ & $2242 \pm 66$ & $2176-2308$ & $-7.08^{c}-0.33$ & $\begin{array}{l}\text { Decomposed organic material } \\
\text { with rootlets }\end{array}$ \\
\hline Poz- 24269 & $110-111$ & $6840 \pm 40$ & $7672 \pm 37$ & $7635-7709$ & $0.02-0.02$ & $\begin{array}{l}\text { Peaty, strongly decomposed } \\
\text { material }\end{array}$ \\
\hline Erl- 12179 & $141-142$ & $7611 \pm 53$ & $8428 \pm 41$ & $8386-8469$ & $0.37-0.46$ & $\begin{array}{l}\text { Clay with limnic material and } \\
\text { plant residues }\end{array}$ \\
\hline
\end{tabular}

Sedimentation rates refer to the time span between the calibrated radiocarbon date in the same row and that in the row above; for the first sedimentation rate an age of -57 for the top sample was assumed

${ }^{a}$ The calibrated age is the mean probability of the range of $1 \sigma$. Calibration is based on the CalPal 2007 HULU curve for the Northern Hemisphere (Weninger et al. 2010).

${ }^{\mathrm{b}}$ Date treated as an outlier, not considered for age-depth model or sediment accumulation rates

${ }^{\mathrm{c}}$ The negative values is a result of overlapping radiocarbon datings which cause the sedimentation rate to be negative when taking the maximum date of one age and the minimum of another

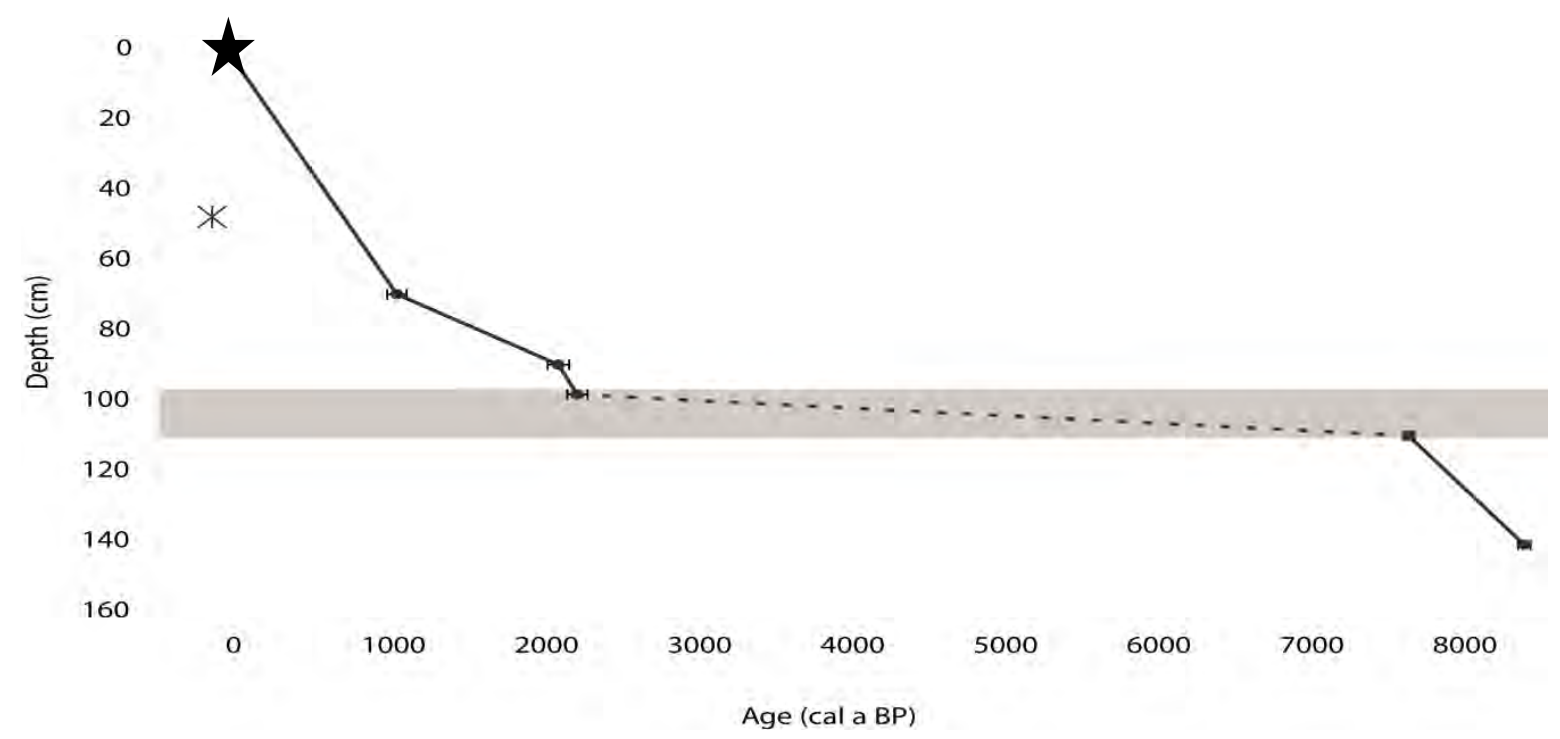

Figure 5 Age-depth relationship (linear interpolation, cal. yr BP/core depth in $\mathrm{cm}$ ) based on 5 radiocarbon dates and the surface sample ( $-57 \mathrm{cal}$. yr BP, marked by a star). The outlier at $48.25 \mathrm{~cm}$ is depicted as an asterisk; the possible hiatus from $2242 \pm 66 \mathrm{cal}$. yr BP to $7672 \pm 37 \mathrm{cal}$. yr BP is indicated by a dotted line and a Shaded band. 
This zone is divided into the subzones TL-Ila (97-79 cm, 9 samples, 2250-1600 cal. yr BP) and TLIlb (79-59 cm, 10 samples, 1600-800 cal. yr BP). However, both zones are characterised by a marked decrease in pollen and charcoal concentration (80,000-380,000 grains $\mathrm{cm}^{-3}$ for pollen, and 70,000-350,000 particles $\mathrm{cm}^{-3}$ in the smallest charcoal fraction). Poaceae and Plantago rigida type are the most prominent pollen taxa, but with varying relative abundances. Pollen of Plantago rigida type (29-51\%) shows generally higher values than Poaceae pollen (30-33\%) at the base of subzone TL-Ila, whereas at the top, the pattern is reversed with $34-49 \%$ Poaceae pollen compared to $8-26 \%$ Plantago rigida type pollen. An unknown but characteristic pollen type of Asteraceae reaches values up to $2 \%$ during this zone. Pollen percentages of Lupinus type, Lamiaceae, Apiaceae, and Lysipomia decline and stay at very low values, whereas percentages of Hypericum type (0-5\%), Ranunculus type (up to 12\%) and Eryngium type (up to 26\%) decrease at the base but rise again towards the end of the subzone TL-lla, as do values of Plantago australis type for the first time with only one sample of $10 \%$. Pollen of Polylepis-Acaena type is present. In subzone TL-Ilb percentages of Eryngium type (3-18\%) generally increase, whereas values of Poaceae and Plantago rigida type remain fluctuating. Proportions of Plantago australis type pollen remain higher at the base of the subzone (2-7\%) but decline towards the top. Tree taxa (up to $10 \%)$ reach higher values, mostly on account of slightly increased percentages of Podocarpaceae, Weinmannia, Hedyosmum (all 0-2\%) and Alnus (1-8\%) pollen. Fern and moss taxa also increase in percentages (up to 15\%), due to higher proportions of spores of Huperzia type (1-9\%) and Lycopodium type (0-3\%). Values of Isoëtes peak at the end of the zone and reach $78 \%$.

Zone TL-III (59-43 cm, 8 samples, 800-650 cal. yr BP)

Pollen (ca. 208,000-64,000 grains $\mathrm{cm}^{-3}$ ) and charcoal concentrations (ca. 164,000-59,000 particles $\mathrm{cm}^{-3}$ for the smallest fraction) decrease further throughout this zone. Pollen taxa composition changes considerably. Percentages of Eryngium type (1-5\%), Plantago rigida type (8-13\%), and Senecio type (0-1\%) decrease markedly, whereas Poaceae (42-49\%), Lysipomia (0-2\%), Gentianella type (1-4\%), Caryophyllaceae and Baccharis type (1-2\%) increase in value. Ranunculus type pollen shows higher abundance towards the top of the zone with a peak of $11 \%$ in the last sample.

Percentages of Alnus decrease to $1-4 \%$. However, values of Weinmannia show a small increase to a maximum of $2 \%$. 


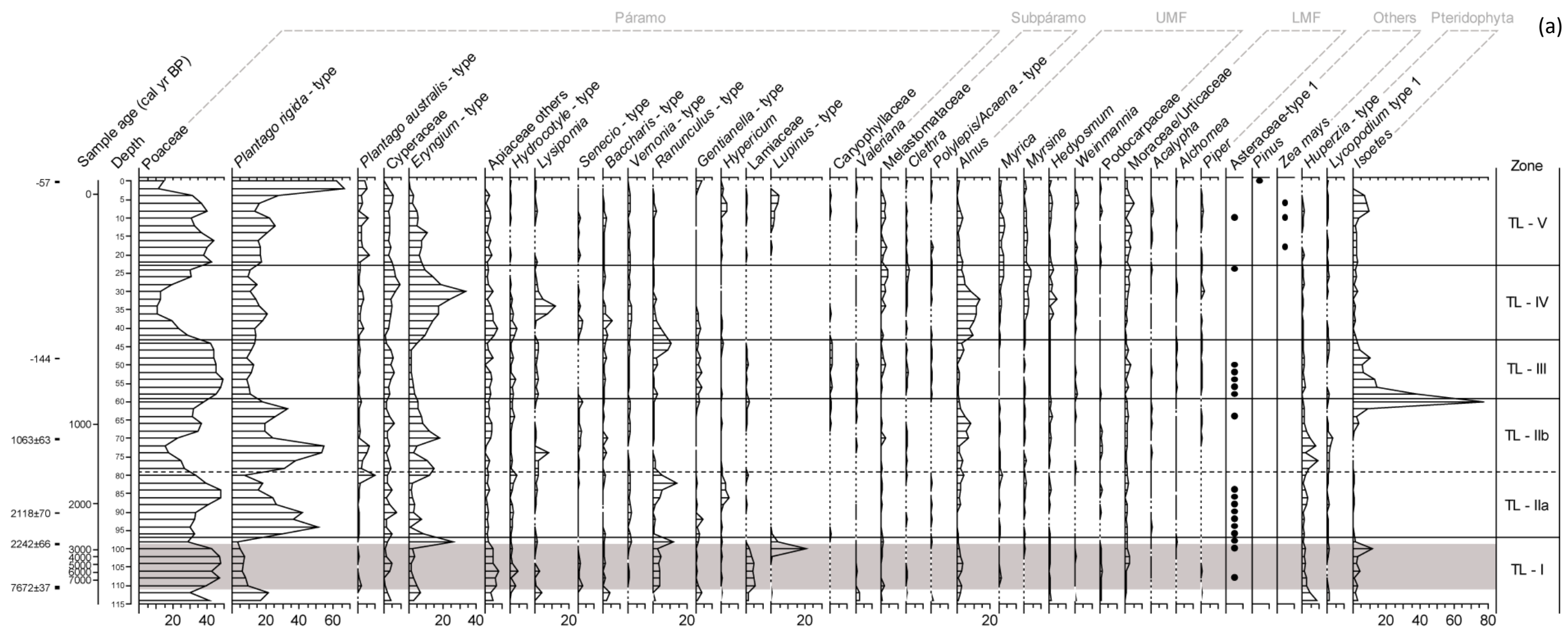

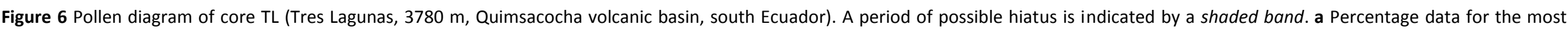

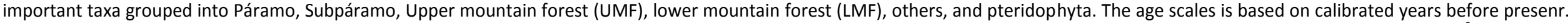

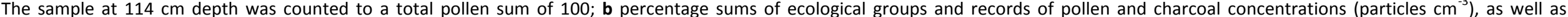
stratigraphy of the core, the total pollen sum and the CONISS cluster analysis 


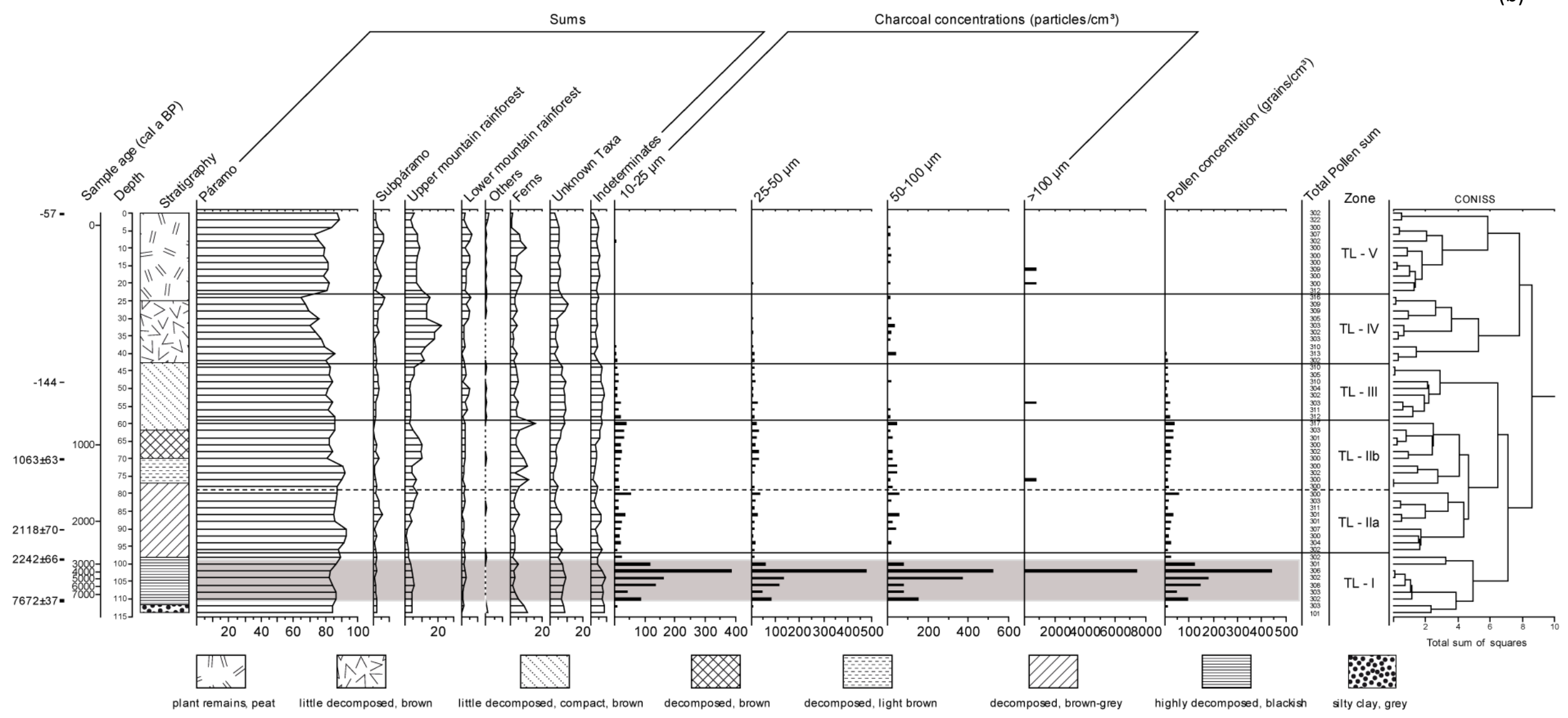


A slight increase of Moraceae/Urticaceae pollen (0-3\%) and the more continuous presence of Alchornea, Acalypha and Piper pollen is recorded. Lower values of Huperzia and Lycopodium (1$4 \%$ lead to a decreased proportion of the fern and moss group. Percentages of Isoëtes remain high at first, but decline towards the top (38-3\%).

Zone TL-IV (43-23 cm, 10 samples, 650-300 cal. yr BP)

Poaceae pollen decreases to a minimum level of $10 \%$ in the middle of the zone. Plantago rigida type stays at lower values. Pollen of most other herb taxa increases in value: Eryngium type (934\%), Cyperaceae (1-9\%), Lysipomia (0-12\%), Apiaceae (1-8\%), Hydrocotyle type, Baccharis type, Senecio type and Vernonia type (all 0-5\%) show their highest percentages in this zone. Melastomataceae pollen increases in percentage and values of Clethra show a small peak. Except for Podocarpaceae, the abundances of all tree taxa increase towards the top of the zone (0-4\%). Particularly high values are shown by Alnus (3-14\%).

Zone TL-V (23-0 cm, 12 samples, 300 to -57 cal. yr BP)

This uppermost zone is characterised by the lowest pollen $\left(16,000-6000\right.$ grains $\left.\mathrm{cm}^{-3}\right)$ and charcoal $\left(14,000-4000\right.$ particles $\left.\mathrm{cm}^{-3}\right)$ concentration values. Percentages of Poaceae (11-44\%) increase at the bottom and of Plantago rigida type (18-66\%) at the top of the zone. Most other taxa show lower values, but Hypericum (0-4\%), Gentianella type and Lupinus type increase in percentages (both $0-4 \%$ ). Proportions of Alnus decrease to $0-4 \%$. Fern and moss spores (1-10\%) increase in percentages. Most tree taxa remain stable in their values, but pollen of Moraceae/ Urticaceae increases further. Pollen of Zea mays type and Pinus is present for the first time.

\subsubsection{Multivariate data analysis}

The PCA revealed the relationships between samples and taxa (Fig. 5). Only 19 of 35 included taxa are displayed, these having a species fit range of $10-100 \%$, meaning that only those taxa are shown for which the axes explain the percentage variability of the species data to at least $10 \%$. The eigenvalues are 0.251 for axis 1 and 0.208 for axis 2. Envelopes around the samples of each zone indicate the main differences in vegetation composition of the different zones. Plantago rigida type is the taxon with the highest explanatory value and corresponds best to zone TL-V. The taxon that shows the best relation to Plantago rigida type is Pinus. However, many other taxa, like Baccharis type, Melastomataceae, Ranunculus type, and Apiaceae are negatively correlated with these two taxa. Also, the first zone, TL-I, is negatively correlated to zone TL-V. Alnus and Eryngium type have a neutral relationship with the groups mentioned before but show strong 


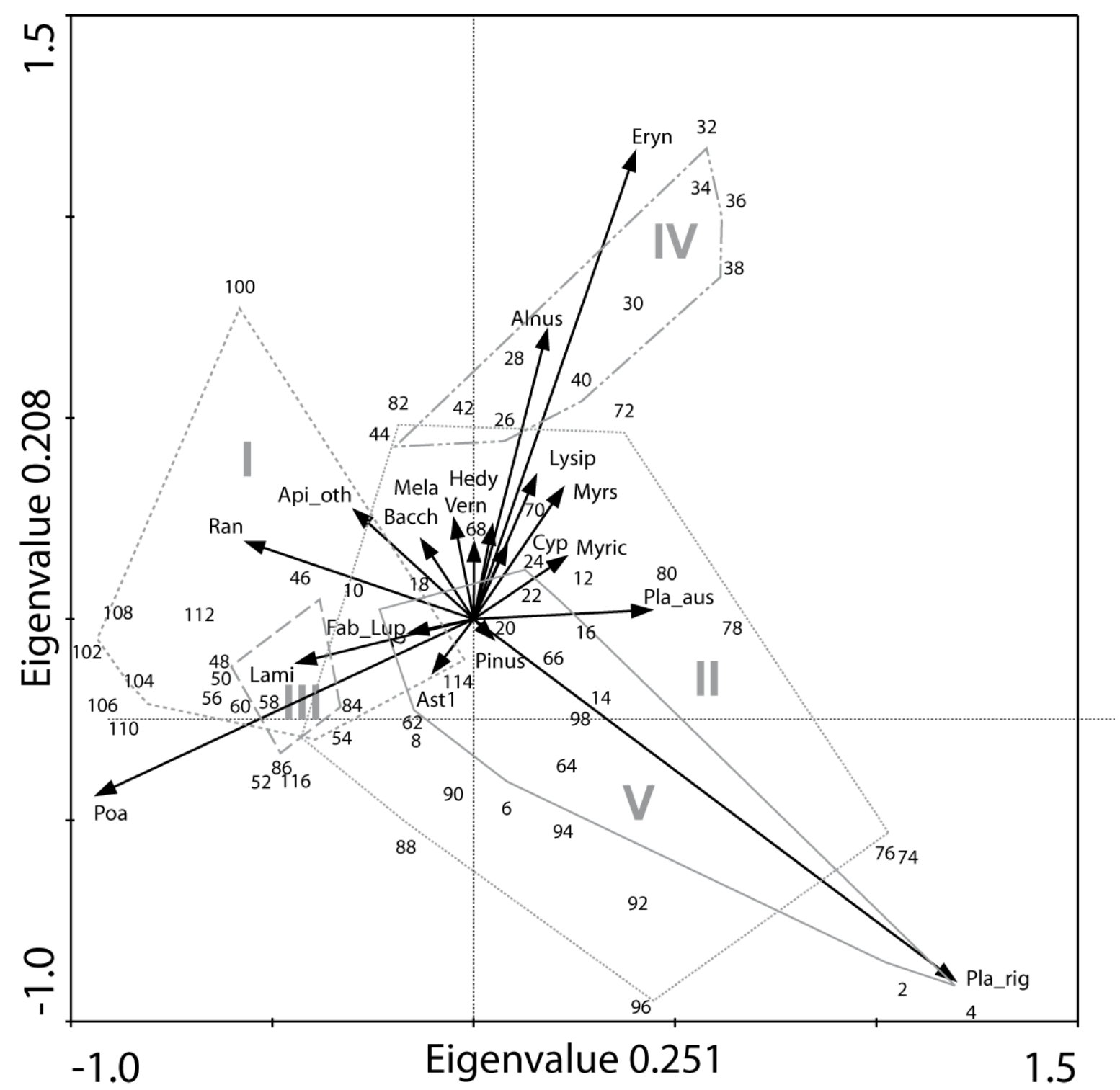

Figure 7 Results of the PCA of square-root transformed percentile pollen data from the Tres Lagunas region in the Quimsacocha volcanic basin in south Ecuador. Included are all samples and the taxa that had a species fit range of 10-100\%. Numbers correspond to sample depths, taxa are depicted with an arrow. Envelopes mark the outer border of the samples of each zone (I, II, III, IV, V). Taxa abbreviations: Alnus, Alnus; Api_oth, Apiaceae excluding Hydrocotyle and Eryngium type; Ast1, Asteraceae type 1; Bacch, Baccharis type; Cyp, Cyperaceae; Eryn, Eryngiumtype; Fab_Lup, Fabaceae Lupinus type; Hedy, Hedyosmum; Lami, Lamiaceae; Lysip, Lysipomia type; Mela, Melastomataceae; Myric, Myricaceae; Myrs, Myrsinaceae; Pinus, Pinus; Pla_aus, Plantago australis type; Pla_rig, Plantago rigidatype; Poa, Poaceae; Ran, Ranunculus type 1; Vern, Vernonia type.

positive correlation with each other and correspond best to the samples of zone TL-IV. Taxa correlating positively with them are Lysipomia, Cyperaceae, Myrsine, Hedyosmum and Vernonia type. Poaceae show high negative correlations with Myrica and Myrsine and correlate best with Lamiaceae, the unknown Asteraceae, and Lupinus type. 


\subsection{Interpretation and discussion}

\subsubsection{Early Holocene (7800-7700 cal. yr BP)}

The core derived from the Tres Lagunas-region of the Quimsacocha volcanic basin reflects local, regional and global vegetation dynamics since the early Holocene at ca. 7800 cal. yr BP. As one date was too young at the top of the core $(-144$ cal. $\mathrm{yr} B P$ at $48-48.5 \mathrm{~cm})$, root penetration that would have caused a bias towards younger dates cannot fully be excluded throughout the whole core. However, roots and rootlets have been removed from the material dated, and could only be recognized visually in the dated samples at $48-48.5 \mathrm{~cm}$ and $98.5-99$ $\mathrm{cm}$ depth. The probability of contamination seems thus to be generally low in most samples. Even though the core reaches back further to a dated age of $8428 \pm 41$ cal. yr BP, pollen could not be counted because of very bad pollen preservation and low pollen concentrations of $>5,000$ grains $\mathrm{cm}^{-3}$. This, together with the fact that the sediment below $111.5 \mathrm{~cm}$ depth in the core is compact silty clay with sand particles and little organic material, indicates erosion and an oxidising environment during the early Holocene. This could either be caused by repeated wet and dry cycles due to an enhanced seasonality (Tweddle and Edwards 2010), or by particularly high rainfall events that led to soil erosion (Wilmshurst and McGlone 2005). The lowermost counted samples had pollen spectra containing floristic components present in the Superpáramo (data not shown) which can today be found at altitudes from 4100 to $4500 \mathrm{~m}$ and contains shrubs of the genera Valeriana (Valerianaceae), Chuquiraga, Loricaria, Diplostephium, Pentacalia (Asteraceae), cushion plants like Plantago rigida (Plantaginaceae), Xenophyllum humile (Asteraceae), together with Azorella sp. (Apiaceae), herbs of the families of Lamiaceae and Fabaceae (Lupinus), as well as grasses of the genera Calamagrostis and Festuca (Poaceae). They are also characterised by lower biodiversity and the dominance of temperate and holarctic rather than of neotropical or cosmopolitan taxa (Sklenářand Ramsay 2001; Sklenář2005; Sklenářand Balslev 2007). High values of the genera Huperzia and Lycopodium found here could indicate disturbance (Brunschön and Behling 2009).

\subsubsection{Early to mid-Holocene dry-event (7700 to 2250 cal. yr BP)}

The next samples of the same zone are characterised by highly decomposed peaty sediment. The radiocarbon dates suggest that more than 5000 years are represented in only $11 \mathrm{~cm}$ of sediment $(110.5 \mathrm{~cm}=7672 \pm 37 \mathrm{cal}$. yr BP to $98.75 \mathrm{~cm}=2242 \pm 66 \mathrm{cal}$. yr BP). This could have been caused by a hiatus which could have covered a large part of the mid-Holocene (as indicated by the grey marked section in Figs. 3 and 4). In addition to the compact sediment mentioned before, very high pollen and charcoal concentrations, which are up to an order of 
magnitude higher than in the samples immediately above, may also support the idea that the sediment accumulation rate was considerably low during the mid-Holocene. High pollen concentrations at this time period have also been noted by Bosman et al. (1994) for the Páramo of Turbera de Calostros in the eastern Cordillera of Colombia, and by Weng et al. (2006) for the western Cordillera of Peru. Also, Paduano et al. (2003) report higher pollen concentrations and influx values for the period between ca. 8000-3100 cal. yr BP from Lake Titicaca. A plausible explanation for this phenomenon would be a warmer climate that led to much faster peat decomposition (Coûteaux et al. 2002) and prevented sediment accumulation. Furthermore, drier conditions are known to increase the sensitivity of peat decomposition to temperature (Ise et al. 2008). Due to the fact that an abrupt change of sedimentation rate, charcoal concentrations and stratigraphy took place, we suggest a hiatus in the sediment. Sediment hiatuses can indicate a complete drying out of the sediment. Hiatuses for the midHolocene have for example been reported from two shallow lakes (Lago Marcio and Lago Tapera) in the eastern Amazon basin region (De Toledo and Bush 2007). Here, the authors suggest they are mainly due to the low stand of the Amazon River during that time. This in turn would be caused by a major drought in the Andean watershed regions, such as the Quimsacocha volcanic basin. A drier environment is also reflected in the pollen composition, with very high values of Poaceae and the presence of Senecio type as well as of Baccharis type and Alnus (most probably Alnus acuminata), which coincide with low levels of Plantago rigida type pollen. Furthermore, a less humid environment is indicated by very high charcoal concentrations in this zone. Similar observations have been noted for Lagunas Chorreras in the Cajas National Park about $50 \mathrm{~km}$ northwards (Hansen et al. 2003) and the El Tiro Pass in the Podocarpus National Park further south (Niemann and Behling 2008). Human presence in the study area could be a possible reason for enhanced fire activity, as no active volcanoes are close by. On the other hand, the significance of the concentration of charred particles should not be overestimated. Due to the very low sedimentation rate, charcoal counts appear to be very high, even though they may not be much higher than in the rest of the core if one takes the time span into account. Also, a dry event could have led to more frequent fires, which in turn may have further enhanced decomposition by removing a proportion of the annual accumulating biomass, thus leading to a decreased sedimentation rate. A drier early-to midHolocene has been recorded throughout many regions of the northern and central Andes. Marchant et al. (2002) report from a multi-proxy study across Colombia a general change to more xeric biomes with an onset occurring between 8500 and 4500 cal. yr BP In Andean Ecuador, evidence for a drier period has been very scarce so far. Hansen et al. (2003) report higher fire frequencies due to the availability of woody fuel and warmer climatic conditions 
with moderate seasonality for the period between 10000 and 7500 cal. yr BP for Lagunas Chorreras and Laguna Pallcacocha in southwestern Ecuador $\left(2^{\circ} \mathrm{S}, 3,700\right.$ and. 4,060 $\mathrm{m}$ a.s.l. respectively). In southeastern Ecuador, there is no evidence for a major drought event. Brunschön and Behling (2009) report highest temperatures between ca. 9300 and 8500 cal. yr BP and at ca. 8000 cal. yr BP the replacement of Subpáramo vegetation with páramo vegetation (mostly Poaceae) at Cerro Toledo ( $4^{\circ} \mathrm{S}, 3,150 \mathrm{~m}$ a.s.I.). Here, however, continuously higher proportions of Sphagnum indicate moister conditions. At the El Tiro pass $\left(3^{\circ} \mathrm{S}, 2810 \mathrm{~m}\right.$ a.s.l.), about $50 \mathrm{~km}$ north of Cerro Toledo, Páramo was replaced by Subpáramo vegetation, thus showing a contrary development (Niemann and Behling 2008). The authors suggest somewhat drier conditions, as fern spores decrease and charcoal influx increases. In northern Peru, there is evidence for an early Holocene dry-event from 9500 to 7300 cal. yr BP in Laguna de Chochos ( $7^{\circ} \mathrm{S}, 3285 \mathrm{~m}$ a.s.l.). At the nearby Laguna la Compuerta $\left(7^{\circ} \mathrm{S}\right)$, a shorter dry phase from 10,000 to 5500 with a peak at about 8500 cal. yr BP is indicated, which coincided with the glacial recession from the lake catchment area (Weng et al. 2006). At Lake Titicaca, southern Peru/Bolivia (3810 m, 16-205), a dry phase between ca. 9000-3100 cal. yr BP with a peak between 6000 and 4000 cal. yr BP is recorded by Paduano et al. (2003) through a changing pollen composition that shows sharp decreases of concentrations of Cyperaceae and Isoëtes and a rise of taxa that can indicate saline conditions, such as Amaranthaceae/Chenopodiaceae. A more severe dry phase from 6000 to $2400 \mathrm{cal}$. yr BP is reported from central Bolivia (Taypi Chaka Kkota, $16^{\circ} \mathrm{S}$, Abbott et al. 2003). Hillyer et al. (2009) and Valencia et al. (2010) record low lake levels from 10000 to 8700 cal. yr BP for Laguna Pacucha, south Peru (13ㅇㄱ), which was followed by volatile lake levels from ca. $8300-5000$ cal. yr BP. The underlying cause for this event is most probably a change of orbital parameters which resulted in a higher solar insolation during summer in boreal and equatorial regions (Berger and Loutre 1991). This could either have directly or indirectly caused a drier climate. Direct effects could have emerged through changes in the sea surface temperature (SST) gradient across the tropical Pacific, which would lead to strengthened easterly winds and a seasonally cooler eastern tropical Pacific (Clement et al. 2000). Indirect effects could have resulted from a more northern mean position of the Intertropical convergence zone (ITCZ), as is recorded by Haug et al. (2001). This would have led to stronger south-easterly trade winds, more oceanic upwelling, cooler SSTs and reduced precipitation (Conroy et al. 2008; Mitchell and Wallace 1991). Abbott et al. (2003) detect a time-transgressiveness of the mid-Holocene dry event for the Andes, with more severe and longer droughts occurring in the central Bolivian Andes, and shorter and less intense dry phases for more northern sites. This seems to hold true, however there are still uncertainties about the time of the onset of moister conditions at the sites. Even though at the 
northernmost Peruvian sites investigated by Abbott et al. (2003), moist conditions returned as early as $4800 \mathrm{cal}$. yr BP, this cannot be generalized as being true for all northern central Andes records. Our record indicates a much later onset of moist conditions at about $2250 \mathrm{cal}$. yr BP Results reported for the El Junco crater lake on the Galapagos Islands show that there, dry episodes occurred prior to $6000 \pm 10$ cal. yr BP and at $5600 \pm 100$ cal. yr BP but were also noticeable between $3800 \pm 40$ and $3200 \pm 160$ cal. yr BP Here, a two-step transition to higher lake levels from $3200 \pm 160$ and $2000 \pm 100$ cal. yr BP onwards is indicated (Conroy et al. 2008). Due to the possible hiatus in our record and the high sedimentation rate we cannot exclude a similar transition, which would well fit into the theory of less severe occurrences in the northern central Andes, which are possibly due to a progressively southward shift in the location and a strengthening of the wet season (Paduano et al. 2003).

\subsubsection{Late Holocene (2250 to -57 cal. yr BP)}

At the beginning of pollen zone TL-Ila (at ca. 2240 cal. yr BP), vegetation changes suggest a moister and cooler environment, as Plantago rigida type becomes very abundant in the pollen spectrum while sediment accumulation together with pollen and charcoal concentrations decrease to much lower values. Other species, such as Ranunculus type, Hypericum type, and Plantago australis type also indicate humid surroundings. However, one has to consider that pollen assemblages of peat bogs are typically dominated by pollen from vegetation within a few metres ( $\sim 0.5-10 \mathrm{~m}$ ) of the sampling point, which can make an interpretation in terms of environmental changes on the regional scale difficult if peat-land taxa are the dominant pollen type (Hicks et al. 2001; Bunting 2003). In pollen zone TL-Ilb, changes in pollen composition point to a drier climate, as Eryngium type, Alnus, Huperzia type and Lysipomia type become more important pollen taxa. However, all these taxa can either point to drier conditions or to disturbance (Ayers 1997; Weng et al. 2004; Brunschön and Behling 2009). Taxa of the upper mountain rainforest also increase in abundance in this zone, and are thus indicating an upward shift of the upper forest-line or a change towards windier conditions. The latter could not only explain the higher representation of forest taxa, but also the higher abundances of taxa that indicate drier conditions, as evaporation would be enhanced. In zone TL-III, a change towards a considerably moister and also colder environment is indicated. Very high values of Poaceae and Isoëtes, accompanied by raised values of Lamiaceae, Gentianella type, Caryophyllaceae and Valeriana as taxa of mainly Superpáramo, as well as the decrease in upper mountain rainforest taxa, are characteristic of this period. Furthermore, multivariate analysis revealed that the samples of this zone are positively correlated to the first samples of zone I (Fig. 5). This cooling period could possibly relate to a period corresponding to the Little Ice Age ( $\sim 1350-$ 
1850 A.D., e.g. Wanner et al. 2008) which is also recorded for other regions of the Andes (Thompson et al. 1986; Rabatel et al. 2005; Polissar et al. 2006), even though the timing of this event is not fully resolved. The two uppermost pollen zones are characterised by higher values of the vegetation types of Subpáramo and upper and lower mountain rainforest. This suggests that the present upper forest-line was formed in the area around this time. In zone TL-IV, Poaceae and Plantago rigida type as highest pollen producers show both low values, thereby causing an elevation of the values of many other pollen taxa of the Páramo. Climate seems to be mesic at this period, as no specific group of taxa dominates the pollen-spectrum. However, Alnus, Eryngium type and Lysipomia reappear with higher values, which could be a signal of disturbance. In zone TL-V the present conditions of the Páramo at Tres Lagunas are being established. Poaceae and Plantago rigida type both obtain very high values and anthropogenically introduced taxa such as Pinus and Zea mays are recorded for the first time. Higher values of Isoëtes and ferns and mosses in general indicate a moist environment which is reported throughout the central to northern Andes (see Baker et al. 2001; Marchant et al. 2002; Niemann and Behling 2009 for an overview).

\subsubsection{Fire record and early human influence in the Páramo of Quimsacocha}

Human-environment relationships have a long and diverse history in the region of the central to northern Andes (Contreras 2010). In the highlands, pastoralism was practiced since preColumbian times (D'Altroy 2000; Sarmiento 2002). In this context, fire is and was regularly used by pastoralists and hunters of the High Andes to encourage the growth of tender forage (Cierjacks et al. 2007; Contreras 2010; Purcell and Brelsford 2004). In the Quimsacocha volcanic basin, this practice is still carried out at the present time (personal observation). However, traces of present local fire could not be confirmed in the charcoal-record, as concentrations were generally very low. Even though charcoal particles were grouped into classes of different sizes in order to be able to distinguish local from regional fires, this distinction could not be made, as bigger charcoal particles were very rare. These findings can supposedly be explained by the fact that the herbal vegetation only burns very superficially, as humid soil conditions prevent herbs and shrubs from blazing thoroughly (personal observation, see Fig. 2). Moist conditions could also lead to lower burning temperatures, which result in scorched but not completely charred particles (Whitlock and Larsen 2001). Thus, this could mean that even though fire may have caused changes in the vegetation composition of the Páramo, it cannot be detected with certainty by counting charcoal. On the other hand, lower charcoal concentrations in the present could indicate that fire activity was even higher in the past. When considering the charcoal record, fire intensity seems to have been highest during 
the early mid-Holocene. However, this appearance may be due to the fact that the sediment is very compressed at the corresponding depth. Therefore the charcoal record does not necessarily indicate that the most severe fires occurred during this period. Whether fires in early Holocene times were caused by humans who had been living in the central Andes since at least the late Pleistocene (Nuñez et al. 2002) is still under discussion (Weng et al. 2006). However, even nomad hunters would have made their work easier if they had used fire as a tool for hunting camelid herds, and there is no reason to doubt their ability to have done so. The earliest record of human occupation in the region of the southern Ecuadorian Andes close to the Quimsacocha volcanic basin is Chobshi Cave (8000 B.P., Lynch and Pollock 1971 in Valdez 2008), but earlier occupation of the Andes is known from the El Inga, close to Quito (11,000 B.P.), and Cubilan (10,000 B.P.), about 100 km north of Loja (Mayer-Oakes 1986; Temme 1982 in Valdez 2008). Furthermore, not even a very early slash-and burn cultivation can be fully excluded, as the finding of a very early (9320 cal. yr BP) domestication of Cucurbita in the southwestern Coastal region illustrates (Piperno and Stothert 2003). A further indication of fire during past times could be the absence versus the rare occurrence of Polylepis/Acaena type pollen in the palaeoecological record. Even though a distinction of the pollen grains is not possible, the pollen in this case most probably originated from the genus Polylepis, as Acaena is not recorded at high abundances in this Páramo at the present time. Polylepis occurs naturally, at least on the slopes and more protected ridges of the area, and might have had a bigger range in the past (Purcell and Brelsford 2004), even though higher abundances were not encountered in the pollen record. During the past, Polylepis-pollen was only present when moister conditions prevailed on the plateau. As Polylepis is known to be very sensitive to fire and to need a long time to regenerate (Cierjacks et al. 2007; Kessler 2002), the presence of this taxon indicates a moist period without fires, whereas its absence can suggest that more severe fires occurred during drier periods. Similar observations have also been made by Urrego et al. (2011), who report that, with the onset of fire, a reduction of forest patches took place in Southern Peru. Here, the Polylepis patches were replaced by grassland. Also, Polylepis is known to switch away from sexual reproduction when facing less favorable conditions, and so is absent from the pollen record (Gosling et al. 2009). Other taxa, such as Hypericum and Gentianella seem to be absent under similar conditions as Polylepis.

\subsection{Conclusions}

The record Tres Lagunas from the Quimsacocha basin in south Ecuador provides a detailed history of the vegetation and fire dynamics of the north-western Andes since the early Holocene. The period between ca. 7600 and 2200 cal. yr BP is characterised by a very low 
sediment accumulation rate which results also in very dense sediment and high pollen as well as charcoal concentrations. Sharp changes in the proxies suggest a hiatus for this period. Poaceae is the most abundant taxon during this time. All this reflects a much warmer and drier climate during the early to mid-Holocene, which can be observed throughout the central Andes region. The late Holocene begins with a change to cooler and moister conditions at ca. 2200 cal. yr BP in which Plantago rigida type dominates the record. The conditions then change about 1000 years later towards a drier habitat, which is dominated by indicators of disturbance such as Eryngium type, Alnus and Huperzia. Then, a colder and very moist period, which could correspond to the Little Ice Age, is recorded. During the last two pollen zones, an upward shift of the upper forest-line to the present conditions can be observed. Stronger human influence is recorded especially during the last 200 year B.P., but an early Holocene presence of fire with correlating phases of disappearance of Polylepis seem to point towards an earlier interference.

\subsection{Acknowledgments}

We thank Corinna Brunschön, Fernando Rodriguez and Patricio Crespo for assistance in the field. We acknowledge the regional team of the FOR 816 for logistical support and Prof. Antoine Cleef for the determination of plant taxa. The comments of William Gosling and one anonymous reviewer helped to improve the quality of the manuscript. This research was supported by the Deutsche Forschungsgemeinschaft (DFG) Grant FOR 816/D1 (BE2116/8-2).

\subsection{References}

Abbott, M., B. Wolfe, A. Wolfe, G. Seltzer, R. Aravena, B. Mark, P. Polissar, D. Rodbell, H. Rowe, and M. Vuille. 2003. Holocene paleohydrology and glacial history of the central Andes using multiproxy lake sediment studies. Palaeogeography, Palaeoclimatology, Palaeoecology 194:123-138.

AMBIGEST (Gestion Ambiental C. Ltda). 2005. IAMGOLD áreas mineras "Cerro Casco" y "Rio Falso" -Estudio ampliatorio de impacto ambiental y plan de manejo ambiental. http:// www.quimsacocha.com/. Accessed 3 Dec 2010.

Ayers, T. 1997. Three new species of Lysipomia (Lobeliaceae) endemic to the Páramos of southern Ecuador. Brittonia 49: 433-440.

Baker, P., C. Rigsby, G. Seltzer, S. Fritz, C. Lowenstein, N. Bacher, and C. Veliz. 2001. Tropical climate changes at millennial and orbital timescales on the Bolivian Altiplano. Nature 409:698-701.

Balslev, H., and J. Luteyn. 1992. Páramo: an Andean ecosystem under human influence. Academic Press, London

Beck, E., F. Makeschin, F. Haubrich, M. Richter, J. Bendix, and C. Valerezo. 2008. The ecosystem (Reserva Biológica San Francisco). Pages 1-13 in: Beck, E., J. Bendix, I. Kottke, F. Makeschin, and R. Mosandl, editors. Gradients in a tropical mountain ecosystem of Ecuador. Springer, Berlin. 
Bendix, J., R. Rollenbeck, and W. Palacios. 2004. Cloud detection in the Tropics-a suitable tool for climate-ecological studies in the high mountains of Ecuador. International Journal of Remote Sensing 25:4521-4540.

Berger, A., and M. Loutre. 1991. Insolation values for the climate of the last 10 million years. Quaternary Science Reviews 10:297-317.

Bosman, A., H. Hooghiemstra, and A. Cleef. 1994. Holocene mire development and climatic change from a high Andean Plantago rigida cushion mire. The Holocene 4:233-243.

Brunschön, C., and H. Behling. 2009. Late Quaternary vegetation, fire and climate history reconstructed from two cores at Cerro Toledo, Podocarpus National Park, southeastern Ecuadorian Andes. Quaternary Research 72:388-399.

Brunschön, C., T. Haberzettl, and H. Behling. 2010. High-resolution studies on vegetation succession, hydrological variations, anthropogenic impact and genesis of a subrecent lake in southern Ecuador. Vegetation History and Archaeobotany 19:191-206.

Bunting, J. 2003. Pollen-vegetation relationships in non-arboreal moorland taxa. Review of Palaeobotany and Palynology 125:285-298.

Bush, M., and C. Weng. 2007. Introducing a new (freeware) tool for palynology. Journal of Biogeography 34:377-380.

Bush, M., B. Hansen, D. Rodbell, G. Seltzer, K. Young, B. León, M. Abbott, M. Silman, and W. Gosling. 2005. A 17,000-year history of Andean climate and vegetation change from Laguna de Chochos, Peru. Journal of Quaternary Science 20:703-714.

Buytaert, W., J. Sevink, B. Deleeuw, and J. Deckers. 2005. Clay mineralogy of the soils in the south Ecuadorian Páramo region. Geoderma 127:114-129.

Cierjacks, A., S. Salgado, K. Wesche, and I. Hensen. 2007. Post-fire population dynamics of two tree species in high-altitude polylepis forests of Central Ecuador. Biotropica 40:176182.

Clement, A., R. Seager, and M. Cane. 2000. Suppression of El Niño during the Mid-Holocene by changes in the Earth's orbit. Paleoceanography 15:731.

Colinvaux, P., M. Bush, M. Steinitz-Kannan, and M. Miller. 1997. Glacial and postglacial pollen records from the Ecuadorian Andes and Amazon. Quaternary Research 48:69-78.

Conroy, J., J. Overpeck, J. Cole, T. Shanahan, and M. Steinitz-Kannan. 2008. Holocene changes in eastern tropical Pacific climate inferred from a Galápagos lake sediment record. Quaternary Science Reviews 27:1166-1180.

Contreras, D. 2010. Landscape and environment: insights from the prehispanic Central Andes. Journal of Archaeological Research 18:241-288.

Coûteaux, M., L. Sarmiento, P. Bottner, D. Acevedo, and J. Thiéry. 2002. Decomposition of standard plant material along an altitudinal transect $(65-3968 \mathrm{~m})$ in the tropical Andes. Soil Biology and Biochemistry 34:69-78.

D'Altroy, T. 2000. Andean land use at the cusp of history. Pages 357-390. in: Lentz, D. editor. Imperfect balance: landscape transformations in the Precolumbian Americas. Columbia University Press, New York.

De Toledo, M., and M. Bush. 2007. A mid-Holocene environmental change in Amazonian savannas. Journal of Biogeography 34:1313-1326.

Emck, P. 2007. A Climatology of South Ecuador-with special focus on the Major Andean Ridge as Atlantic-Pacific Climate Divide. Dissertation, University Erlangen-Nürnberg.

Fægri, K., and J. Iversen. 1989. Textbook of pollen analysis. Wiley, Chichester.

Farley, K. 2007. Grasslands to tree plantations: forest transition in the Andes of Ecuador. Annals of the Association of American Geographers 97:755-771.

Finsinger, W., W. Tinner, and F. Hu. 2008. Rapid and accurate estimates of microcharcoal content in pollen slides. Pages 121-124. in: Fiorentino, G., and D. Magri, editors. Charcoals from the past: cultural and palaeoenvironmental implications: proceedings of the Third International Meeting of Anthracology, Cavallino-Lecce (Italy) 2004. Hadrian Press, Oxford. 
Gosling, W., J. Hanselman, C. Knox, B. Valencia, and M. Bush. 2009. Long-term drivers of change in Polylepis woodland distribution in the central Andes. Journal of Vegetation Science 20:1041-1052.

Grimm, E. 1987. CONISS: a Fortran 77 program for stratigraphically constrained cluster analysis by the method of the incremental sum of squares. Computer and Geosciences 13:1335.

Hansen, B., D. Rodbell, G. Seltzer, B. Leon, K. Young, and M. Abbott. 2003. Late-glacial and Holocene vegetational history from two sites in the western Cordillera of southwestern Ecuador. Palaeogeography, Palaeoclimatology, Palaeoecology 194:79-108.

Harden, C. 2007. Two soil toposequences in a tropical glacial trough, southern Ecuador. Zeitschr ift für Geomorphologie, Supplementary Issue 51:139-152.

Haug, G., K. Hughen, D. Sigman, L. Peterson, and U. Röhl. 2001. Southward migration of the intertropical convergence zone through the Holocene. Science 293:1304-1308.

Hicks, S., H. Tinsley, A. Huusko, C. Jensen, M. Hättestrand, A. Gerasimides, and E. Kvavadze. 2001. Some comments on spatial variation in arboreal pollen deposition: first records from the Pollen Monitoring Programme (PMP). Review of Palaeobotany and Palynology 117:183-194.

Hillyer, R., B. Valencia, M. Bush, M. Silman, and M. Steinitz-Kannan. 2009. A 24,700-yr paleolimnological history from the Peruvian Andes. Quat Res 71:71-82

Hofstede, R., J. Groenendijk, R. Coppus, J. Fehse, and J. Sevink. 2002. Impact of pine plantations on soils and vegetation in the Ecuadorian High Andes. Mountain Research and Development 22:159-167.

Homeier, J., F. Werner, R. Gradstein, S.-W. Breckle, and M. Richter. 2008. Potential vegetation and floristic composition of Andean forests in South Ecuador, with a focus on the RBSF. Pages 87-100 in: Beck, E., J. Bendix, I. Kottke, F. Makeschin, and R. Mosandl, editors. Gradients in a tropical mountain ecosystem of Ecuador. Springer, Berlin.

Hooghiemstra, H. 1984. Vegetation and Climatic History of the High Plain of Bogota, Colombia. Cramer, Vaduz.

Hungerbühler, D., M. Steinmann, W. Winkler, D. Seward, A. Egüez, D. Peterson, U. Helg, and C. Hammer. 2002. Neogene stratigraphy and Andean geodynamics of southern Ecuador. Earth Science Reviews 57:75-124.

Ise, T., A. Dunn, S. Wofsy, and P. Moorcroft. 2008. High sensitivity of peat decomposition to climate change through water-table feedback. Nature Geoscience 1:763-766.

Jørgensen, P., and S. León-Yánez. 1999. Catalogue of the vascular plants of Ecuador. Missouri Botanical Garden, St. Louis.

Kessler, M. 2002. The "Polylepis Problem": where do we stand? Ecotropica 8:97-110.

Luteyn, J. 1999. Páramos: a checklist of plant diversity, geographical distribution and botanical literature. Memoirs of the New York Botanical Garden, Bronx.

Lynch, T., and S. Pollock. 1971. La arqueologı'a de la Cueva Negra de Chobshi. Miscelánea Antropológica Ecuatoriana 1:92-119.

Marchant, R., H. Behling, J. Berrio, A. Cleef, J. Duivenvoorden, H. Hooghiemstra, P. Kuhry, B. Melief, E. Schreve-Brinkman, B. Van Geel, T. Van der Hammen, G. Van Reenen, and M. Wille. 2002. Pollen-based biome reconstructions for Colombia at 3000, 6000, 9000, 12000,15000 and $1800014 \mathrm{C}$ yr ago: late quaternary tropical vegetation dynamics. Journal of Quaternary Science 17:113-129.

Mayer-Oakes, W. 1986. El Inga, a Paleo-Indian site in the Sierra of Northern Ecuador. Transactions of the American Philosophical Society 76:1-235.

Mitchell, T., and J. Wallace. 1991. The annual cycle in equatorial convection and sea surface temperature. Journal of Climate 5:1140-1156.

Mosandl, R., S. Günter, B. Stimm, and M. Weber. 2008. Ecuador suffers the highest deforestation rate in South America. Pages 37-40 in: Beck, E., Bendix, J., Kottke, I., 
Makeschin, F., and R. Mosandl, editors. Gradients in a tropical mountain ecosystem of Ecuador. Springer, Berlin.

Moy, C., G. Seltzer, D. Rodbell, and D. Anderson. 2002. Variability of El Niño/Southern Oscillation activity at millennial timescales during the Holocene epoch. Nature 420:162-165.

Niemann, H., and H. Behling. 2008. Late Quaternary vegetation, climate and fire dynamics inferred from the El Tiro record in the southeastern Ecuadorian Andes. Journal of Quaternary Science 23:203-212.

Niemann, H., and H. Behling. 2009. Late Pleistocene and Holocene environmental change inferred from the Cocha Caranga sediment and soil records in the southeastern Ecuadorian Andes. Palaeogeography, Palaeoclimatology, Palaeoecology 276:1-14.

Nuñez, L., M. Grosjean, and I. Cartajena. 2002. Human occupations and climate change in the Puna de Atacama, Chile. Science 298:821-824.

Paduano, G., M. Bush, P. Baker, S. Fritz, and G. Seltzer. 2003. A vegetation and fire history of Lake Titicaca since the Last Glacial Maximum. Palaeogeography, Palaeoclimatology, Palaeoecology 194:259-279.

Piperno, D., and K. Stothert. 2003. Phytolith evidence for early Holocene Cucurbita Domestication in Southwest Ecuador. Science 299:1054-1057.

Planiglobe beta.2011. http://www.planiglobe.com. Accessed 16 July 2011.

Podwojewski, P., J. Poulenard, T. Zambrana, and R. Hofstede. 2002. Overgrazing effects on vegetation cover and properties of volcanic ash soil in the páramo of Llangahua and La Esperanza (Tungurahua, Ecuador). Soil Use and Management 18:45-55.

Polissar, P., M. Abbott, A. Wolfe, M. Bezada, V. Rull, and R. Bradley. 2006. Solar modulation of Little Ice Age climate in the tropical Andes. Proceedings of the National Academy of Sciences 103:8937-8942.

Purcell, J., and A. Brelsford. 2004. Reassessing the causes of decline of Polylepis, a tropical subalpine forest. Ecotropica 10:155-558.

Rabatel, A., V. Jomelli, P. Naveau, B. Francou, and D. Grancher. 2005. Dating of Little Ice Age glacier fluctuations in the tropical Andes: Charquini glaciers, Bolivia, $16^{\circ} \mathrm{S}$. Comptes Rendus Geosciences 337:1311-1322.

Ramsay, P., and E. Oxley. 1996. Fire temperatures and postfire plant community dynamics in Ecuadorian grass Páramo. Vegetatio 124:129-144.

Ramsay, P., and E. Oxley. 1997. The growth form composition of plant communities in the ecuadorian Páramos. Plant Ecology 131:173-192.

Rodbell, D. 2002. A late glacial-Holocene tephrochronology for Glacial Lakes in Southern Ecuador. Quaternary Research 57:343-354.

Roubik, D., and J. Moreno. 1991. Pollen and spores of Barro Colorado Island. Missouri Botanical Garden, St. Louis.

Sadori L, Giardini M (2007) Charcoal analysis, a method to study vegetation and climate of the Holocene: the case of Lago di Pergusa (Sicily, Italy). Geobios 40:173-180

Sarmiento, F. 2002. Anthropogenic change in the landscapes of highland Ecuador. Geographical Review 92:213-234.

Sklenář, P. 2005. Superpáramo plant species diversity and phytogeography in Ecuador. Flora 200:416-433.

Sklenář, P., and H. Balslev. 2007. Geographic flora elements in the Ecuadorian Superpáramo. Flora 202:50-61.

Sklenář, P., and P. Ramsay. 2001. Diversity of zonal Páramo plant communities in Ecuador. Diversity and Distributions 7:113-124.

Temme, M. 1982. Excavaciones en el sitio precerámico de Cubilan (Ecuador). Miscelánea Antropológica Ecuatoriana 2:135-165. 
Ter Braak, C., and P. Šmilauer. 2002. CANOCO Reference manual and CanoDraw for Windows User's Guide: Software for Canonical Community Ordination (version 4.5). Microcomputer Power, Ithaka

Thompson, L., E. Mosley-Thompson, W. Dansgaard, and P. Grootes. 1986. The Little Ice Age as Recorded in the Stratigraphy of the Tropical Quelccaya Ice Cap. Science 234:361-364.

Tweddle, J., and K. Edwards. 2010. Pollen preservation zones as an interpretative tool in Holocene palynology. Review of Palaeobotany and Palynology 161:59-76.

Urrego, D., B. Niccum, C. La Drew, M. Silman, and M. Bush. 2011. Fire and drought as drivers of early Holocene tree line changes in the Peruvian Andes. Journal of Quaternary Science 26:28-36.

Valdez, F. 2008. Inter-zonal relationships in Ecuador. Pages 865-888 in: Silverman, H., and W. Isbell, editors. Handbook of South American archeology. Springer, New York.

Valencia, B., D. Urrego, M. Silman, and M. Bush. 2010. From ice age to modern: a record of landscape change in an Andean cloud forest. Journal of Biogeography 37:1637-1647.

Wanner, H., J. Beer, J. Butikofer, T. Crowley, U. Cubasch, J. Flückiger, H. Goosse, M. Grosjean, F. Joos, J. Kaplan, M. Küttel, S. Müller, I. Prentice, O. Solomina, T. Stocker, P. Tarasov, M. Wagner, and M. Widmann. 2008. Mid-to Late Holocene climate change: an overview. Quaternary Science Reviews 27:1791-1828.

Weng, C., M. Bush, and A. Chepstow-Lusty. 2004. Holocene changes of Andean alder (Alnus acuminata) in highland Ecuador and Peru. Journal of Quaternary Science 19:685-691.

Weng, C., M. Bush, J. Curtis, A. Kolata, T. Dillehay, and M. Binford. 2006. Deglaciation and Holocene climate change in the western Peruvian Andes. Quaternary Research 66:8796.

Weninger, B., O. Jöris, and U. Danzeglocke. 2010. Cologne Radiocarbon CALibration \& PALeoclimate Research Package. http:// calpal.de/ Accessed 25 April 2010

Whitlock, C., and C. Larsen. 2001. Charcoal as a fire proxy. Pages 75-98 in: Smol, J., Birks, H., and W. Last, editors. Tracking environmental change using lake sediments. Kluwer, Dordrecht.

Wilmshurst, J., and M. McGlone. 2005. Corroded pollen and spores as indicators of changing lake sediment sources and catchment disturbance. Journal of Paleolimnology 34:503517. 


\section{CHAPTER 3}

\section{Representativeness of tree diversity in the modern pollen rain of Andean montane forests}

Nele Jantz ${ }^{1}$, Jürgen Homeier ${ }^{2}$ \& Hermann Behling ${ }^{1}$

${ }^{1}$ Department of Palynology and Climate Dynamics, Albrecht-von-Haller Institute for Plant Sciences, University of Göttingen, 37073 Göttingen, Germany

${ }^{2}$ Department of Plant Ecology, Albrecht-von-Haller Institute for Plant Sciences, University of Göttingen, 37073 Göttingen, Germany

Journal of Vegetation Science xx (2013)

Doi: $10.1111 /$ jvs.12105/pdf 


\section{Abstract}

Questions

To assess the relationship between modern pollen rain and Andean montane forest vegetation for diversity, and provide a basis for interpretations of palaeoecological data in the northern Andes, we asked: (1) can the reduction of plant and pollen data to family level preserve information about diversity in both datasets; (2) how precisely do tree pollen and spore types represent richness patterns along an altitudinal gradient on tropical mountains; and (3) how similar are tree pollen and spore family richness in relationship to tree family richness?

\section{Location}

Tropical montane rainforests, Podocarpus National Park in the Andes of South Ecuador $\left(3^{\circ} \mathrm{S}\right.$, $79^{\circ} \mathrm{W}, 1000-3000 \mathrm{~m}$ a.s.I.).

\section{Methods}

We analysed tree diversity and species composition in three different rain forest types: Premontane (PMF), lower montane (LMF) and upper montane (UMF). We investigated modern pollen rain using pollen traps. After testing the reliability of a taxonomic surrogacy on the plant data, we compared abundance and representation, as well as diversity of the two datasets at family level. This was done using rarefaction and Sørensen-Indices.

Results

The correlation between tree-species and -families was high $(r=0.81, p<0.001)$. Sample rarefaction on tree pollen and plant family data revealed highest pollen diversity on sites of the UMF, but highest tree diversity on LMF and PMF sites. The Sørensen indices indicate downdrift of pollen from higher altitudes in PMF and LMF and up-drift in UMF. Between 1\% and $50 \%$ of pollen taxa of each sample originate from outside of the plot.

\section{Conclusions}

Taxonomic surrogacy at family level is a good tool for comparing presence-absence patterns of plant and pollen data in tropical regions with high tree diversity. On a family basis, pollen presence-absence data represent the corresponding tree vegetation data, but uncertainties increase with decreasing altitude. The higher diversity in pollen data of the UMF, but slightly lower diversity in the LMF and PMF, can at least partly be explained by wind patterns, local abundance of shrubs and herbs and differences in evenness. 


\section{Keywords}

Ecuador; Palynology; Pollen diversity; Pollen trap; Taxonomic surrogacy; Tropical Andean forests; Tropical mountain vegetation

\subsection{Introduction}

Modern pollen rain has long been recognized as a valuable reference for paleoecological studies (Giesecke et al., 2010) as it provides the necessary base for more quantitative views on past environmental conditions. Studies of modern pollen rain in tropical South and Central America are, however, still scarce, and concentrated on the northern neotropics (e.g. Bush and Rivera, 1998, 2001; Bush, 2000; Correa-Metrio et al., 2011), the central Andes region of Peru and Bolivia (e.g. Kuentz et al., 2007; Ortuño et al., 2011;), Amazonia (e.g. Bush et al., 2001; Berrio et al., 2003; Gosling et al., 2005, 2009; Urrego et al., 2011) and coastal regions (Collins and Bush, 2010). Few studies have been carried out in the northern Andes region (SalgadoLabouriau, 1979; Grabandt, 1980; Witte, 1994; Hansen et al., 2003; Rangel, 2005, Olivera et al., 2009) and only one in the species-rich region of the Andean depression between Girón-Cuenca in South Ecuador and Huancabamba in North Peru (Niemann et al., 2010).

The focus of these studies has mostly been on pollen representation in comparison to vegetation composition, often accompanied by assessments of the pollen spectra of a special ecosystem type. Multivariate analyses, e.g. detrended correspondence analysis (DCA; Bush et al., 2001; Weng et al., 2004; Niemann et al., 2010; Urrego et al., 2011), principal components analysis (PCA; Kuentz et al., 2007) and redundancy and correspondence analyses (RDA/CA; Olivera et al., 2009) have shown to be reliable methods for comparing and differentiating pollen rain spectra from different vegetation types. For plant vs pollen rain representation measurements, different indices, eg. the representation indices of O. Davis (1984) or the Rvalue model of M. B. Davis (1963), have been used to indicate whether a taxon is over-, underor well represented in the modern pollen rain of a given vegetation type (Melief, 1984; Berrio et al., 2003; Rangel, 2005; Gosling et al., 2005; Olivera et al., 2009). For the determination of altitudinal ranges and climatic interpretation values of pollen taxa, probability density functions have been used to calculate the probability of pollen abundance of different pollen taxa along an altitudinal gradient (Urrego et al., 2011) and weighted averaging has been applied to calculate altitudinal ranges of pollen taxa (Witte, 1994). Also, co-inertia analysis between a sample/pollen CA and a PCA of a given sample/climate matrix was found to be useful for revealing pollen/climate relationships that can be used for paleoclimatological reconstructions (Ortuño et al., 2011). 
However, a goal of paleoecological research is also the reconstruction of past diversity, which would be invaluable for biogeographic research and the development of conservation strategies, as a better knowledge of long-term ecological developments is urgently needed to determine suitable regions for conservation of ecological and evolutionary processes through time (Willis et al., 2005, 2007).

Many risks come with the estimation of plant species richness from palynological richness. For example, some species-rich taxa that substantially contribute to high diversity levels in a region, (e.g. Orchidaceae or Lauraceae in neotropical montane forests), will always be underrepresented in the pollen spectra and/or lack the possibility of species or genus determination. Furthermore, the problem of evenness has long been discussed among palynologists as responsible for a biased relationship between pollen taxa and plant species richness (Birks and Line, 1992; Odgaard, 1999, 2001; Weng et al., 2006). This is because the pollen diversity of a given sample of e.g. 300 counted pollen grains decreases when it is dominated by few very abundant pollen taxa but increases when it is evenly distributed among individuals of many rare pollen taxa, even if the total pollen type richness of both populations is equally high.

Nevertheless, first assessments give preliminary but promising results on past biodiversity changes (e.g. Brown 1999; Weng et al. 2006). To lead the way for further establishment of past biodiversity research, more comprehensive knowledge of diversity patterns in the present pollen rain is needed (Weng et al., 2006). This is especially true for tropical hotspot-regions. Generally, the method of individual-based rarefaction that interpolates taxa numbers based on an equal pollen count for every sample is considered to give the most reliable results on pollen diversity and has been widely used for paleoecological diversity estimates (e.g. Birks and Line, 1992; Odgaard, 2001; Weng et al., 2006; van der Knaap, 2009). However, suggested recommendations to increase pollen count in order to obtain more reliable results on pollen diversity have not been applied on a large scale. Yet, as Weng et al. (2006) showed, for a pollen type with a frequency of $<0.1 \%$ to be detected, the pollen count needs to be $>1000$ grains.

In this study, we present the first analysis of modern pollen rain in the northern Andes, which is based on an extended sampling design including detailed tree vegetation analyses (diameter at breast height $(\mathrm{DBH}) \geq 5 \mathrm{~cm}$ ) with six replicate plots for each slope position within one forest type. We use one year of plot-based pollen rain collection along an altitudinal gradient, covering premontane forest (PMF), lower montane forest (LMF) and upper montane forest (UMF), to systematically investigate a highly diverse ecosystem-complex which having a high turnover rate of species. We use high pollen counts (>2000 grains), including the sum of all replicates for one slope position, to increase the probability of detecting rare taxa. 


\subsection{Study region}

The study region is located on the eastern slope of the southern Ecuadorian Andes in the Cordillera del Consuelo. Three study sites were located along an elevational gradient at ca. $1000 \mathrm{~m}$ (Bombuscaro, $04^{\circ} 06^{\prime} \mathrm{S}, 7^{\circ} 58^{\prime} \mathrm{W}, 1020-1270 \mathrm{~m}$ a.s.l.), ca. $2000 \mathrm{~m}$ (San Francisco, $03^{\circ}$ $58^{\prime} \mathrm{S}, 79^{\circ} 04^{\prime} \mathrm{W}, 1910-2090 \mathrm{~m}$ a.s.l.) and ca. $3000 \mathrm{~m}$ (Cajanuma, $04^{\circ} 06^{\prime} \mathrm{S}, 79^{\circ} 11^{\prime} \mathrm{W}, 2800-$

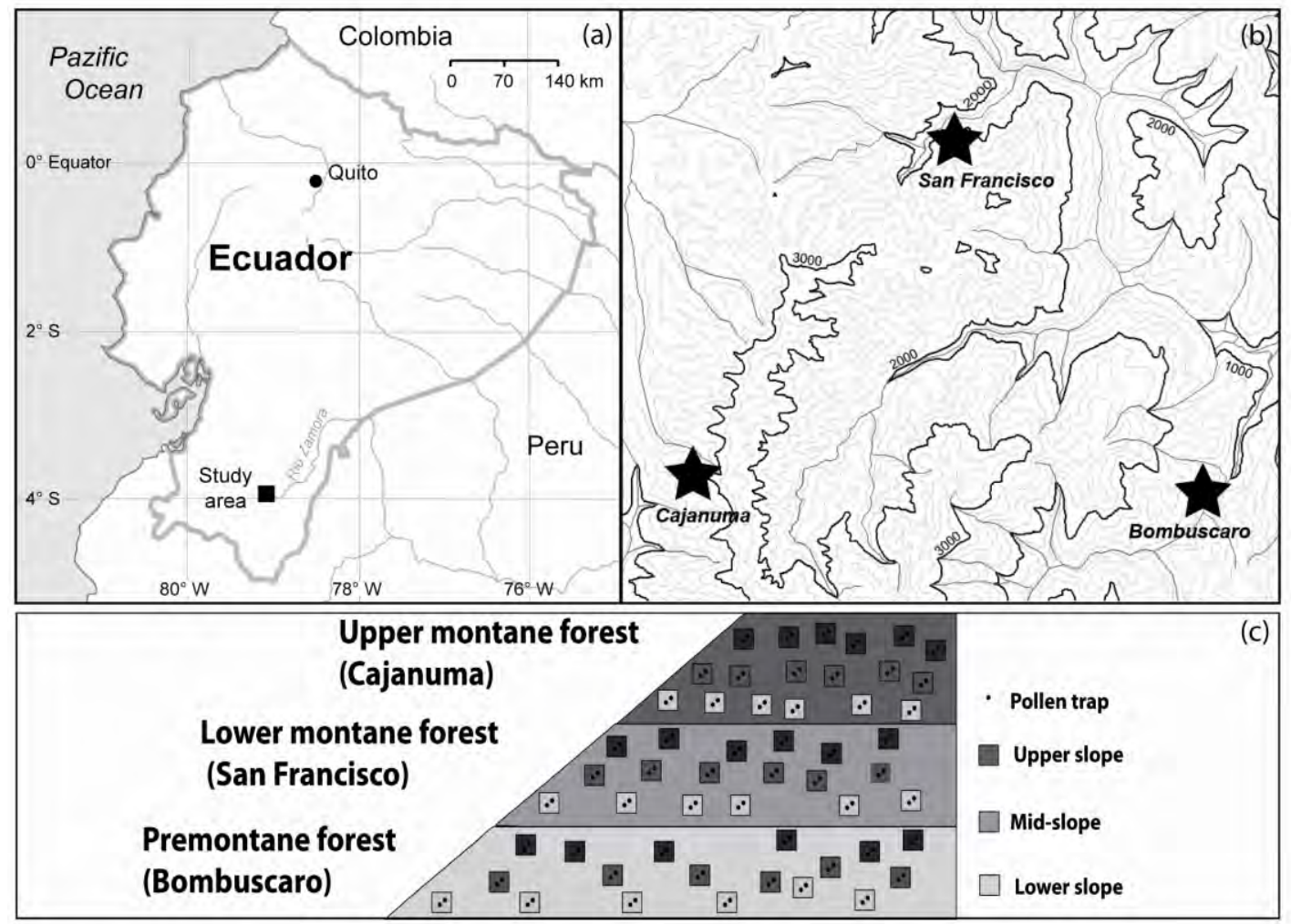

Figure 1 (a) Ecuador and location of the study area. (b) Location of study sites in the study area with contour lines. (c) Sampling design of the experiment. Six $400-\mathrm{m}^{2}$ plots were established at each slope position, resulting in 18 plots for each of the three forest types. Two pollen traps were distributed in each plot.

2900 m a.s.l.) in the Podocarpus National Park and in the Reserva Biológica San Francisco in the Provinces of Loja and Zamora-Chinchipe (Fig. 1). The research area has a tropical humid climate, with a wet season from April to July and a less humid period from September to December (Bendix et al., 2006; Emck, 2007). There are no regularly occurring longer dry periods. The annual mean temperature decreases from $19.4{ }^{\circ} \mathrm{C}$ at the $1000-\mathrm{m}$ site to $9.4{ }^{\circ} \mathrm{C}$ at the 3000-m site, annual precipitation increases from $2230 \mathrm{~mm}$ at $1000 \mathrm{~m}, 1950 \mathrm{~mm}$ at $2000 \mathrm{~m}$, and $4500 \mathrm{~mm}$ at $3000 \mathrm{~m}$ (Moser et al., 2007; Bendix et al., 2008). For most of the study area, Paleozoic metamorphic schists and sandstones with some quartz veins form the parent material for soil development. At $1000 \mathrm{~m}$ there are partly deeply weathered granodioritic rocks of the Jurassic Zamore granitoide formation (Wolf et al., 2011). Soils are Cambisols at the 1000-m site, as well as on the lower and mid-slopes at $2000 \mathrm{~m}$ and partly on lower slopes at $3000 \mathrm{~m}$, with Planosols and Histosols on the upper slopes at $2000 \mathrm{~m}$ and on mid- and upper 
slopes at $3000 \mathrm{~m}$. Thick organic soil layers $(\mathrm{Oi}+\mathrm{Oe}+\mathrm{Oa})$ are found the upper slope positions of all three study sites (Wolf et al., 2011). All three study sites are located in protected forest sections. The three elevation levels correspond to three different forest types (Homeier et al., 2008): At $1000 \mathrm{~m}$, in the transition zone between tropical lowland and lower montane forest, is evergreen premontane rain forest (PMF) up to $40 \mathrm{~m}$ in height. Common tree families of this forest type are Fabaceae, Melastomataceae, Moraceae, Myristicaceae, Rubiaceae and Sapotaceae. The evergreen lower montane rain forest (LMF) at $2000 \mathrm{~m}$ reaches a canopy height of 18-22 m. Characteristic tree families are Euphorbiaceae, Lauraceae, Melastomataceae and Rubiaceae. At $3000 \mathrm{~m}$, are the uppermost stands of evergreen upper montane rain forest (UMF), canopy height is rarely above 8-10 m. Dominant tree families are Aquifoliaceae, Clusiaceae, Cunoniaceae, Lauraceae and Melastomataceae. Stand height decreases with elevation and from the lower slope positions to the ridge positions within every site. In addition, there is a strong effect of topography on tree species composition (Homeier at al., 2010).

\subsection{Methods}

\subsubsection{Vegetation analysis}

To cover a large altitudinal gradient, 18 of the 54 vegetation plots of $20 \times 20 \mathrm{~m}$ were located in each of PMF, LMF and UMF. For each forest type, six plots each were assigned to upper slope, mid-slope and lower slope positions to cover the variable topography of the rugged terrain (Fig. 1, see Appendix S1 for more details on the study sites). The slope positions were defined by their relative location on the mountain, as well as by the thickness of the organic horizon (see Wolf et al., 2011). All plots were covered by mature, closed-canopy forest representative for the respective topographic position (Fig. 1). In the plots, all trees, which in this case are defined as woody plants with a $\mathrm{DBH} \geq 5 \mathrm{~cm}$, were determined to species level (see Appendix S2 for a list of all plant species encountered). For family classification, we followed APG (=The Angiosperm Phylogeny Group) III (2009).

\subsubsection{Pollen traps}

One pollen trap was located in the centre of each plot and left in the field for $1 \mathrm{yr}$ (Nov 2009 Oct 2010). The Pollen traps used consist of a plastic tube of $60 \mathrm{~cm}^{3}, 11.5 \mathrm{~cm}$ long and a diameter of $2.7 \mathrm{~cm}$ (See Jantz et al. 2013 for a more detailed description). Each tube was filled with ca. $5 \mathrm{ml}$ liquid glycerol and synthetic cotton. As glycerol has a higher density than water, 
the pollen that sinks to the bottom is trapped in the glycerol and cotton, whereas water can flow out. The tubes were covered with a synthetic screen mesh to keep out larger particles and were installed about $12 \mathrm{~cm}$ above the ground.

\subsubsection{Pollen analysis}

We analysed one pollen trap per plot, in total 53 , as in the LMF, traps of one plot (lower slope) were lost. Pollen was extracted from the traps by centrifugation and sieving the samples. Afterwards, acetolysis was carried out on the samples to dissolve cellulose and stain the pollen residue. A tablet of $18583 \pm 762$ Lycopodium clavatum spores was added to each sample. Samples were generally counted to a minimum of 300 pollen grains; spores were excluded from the pollen sum (see Appendix S2 for a list of all pollen taxa encountered). If a taxon was $\geq 50 \%$ of the pollen sum, it was excluded from the pollen sum during the counting process of that particular sample to cope with the problem of pollen over-representation. Pollen was determined using the collections of Ecuador and Brazil of the Department of Palynology and Climate Dynamics, University of Göttingen, Germany. Further support for determination was obtained by the electronic pollen keys of Ecuador and southern Brazil kept at this department, as well as the Southern American Pollen Database (Bush and Weng, 2007) and literature (Roubik and Moreno, 1991; Colinvaux and De Oliveira, 1999).

Table 1 Numbers of plant species, tree pollen taxa, as well as plant families/groups of families* (for tree and pollen taxa) for the specific slope positions and each forest type (premontane- PMF, lower montane- LMF and upper montane -UMF - forest). LS = lower slope, MS = Mid-slope, US = Upper slope. ${ }^{*}$ If families cannot be distinguished by pollen morphology

\begin{tabular}{|c|c|c|c|c|c|c|c|c|c|c|c|c|}
\hline \multirow{2}{*}{$\begin{array}{l}\text { Site } \\
\text { Slope }\end{array}$} & \multicolumn{4}{|c|}{ PMF } & \multicolumn{4}{|c|}{ LMF } & \multicolumn{4}{|c|}{ UMF } \\
\hline & LS & MS & US & Sum & LS & MS & US & Sum & LS & MS & US & Sum \\
\hline Tree species & 94 & 117 & 71 & 182 & 94 & 123 & 83 & 200 & 65 & 70 & 58 & 103 \\
\hline Pollen taxa (trees) & 54 & 65 & 45 & 77 & 68 & 67 & 57 & 82 & 53 & 44 & 48 & 66 \\
\hline Families (trees) & 38 & 36 & 29 & 46 & 34 & 45 & 33 & 57 & 29 & 27 & 25 & 36 \\
\hline Families (tree pollen) & 40 & 41 & 32 & 44 & 40 & 43 & 37 & 48 & 37 & 31 & 34 & 41 \\
\hline
\end{tabular}

\subsubsection{Data analyses}

Pollen taxa were grouped according to growth form of the most abundant species into trees, shrubs and subshrubs, epiphytes and herbs, according to the classification of Jørgensen and Ulloa Ulloa (1994) and Jørgensen and León-Yánez (1999). For comparison of pollen spectra and tree composition data, the systematic determination level for both datasets was set to 
families, and where families could not be distinguished by pollen analysis (Moraceae/Urticaceae, Hypericaceae/Clusiaceae, Melastomataceae/Combretaceae) to groups of families. Here, only pollen taxa families that possibly contain tree species were included into the analyses (for a list of all taxa with their group designation see Appendix S2). Pollen taxa that are most probably herbs, but are members of a plant family that contains trees were also excluded. We determined the percentage of tree taxa at family level that were found in the traps but were not part of the local vegetation in the plots.

As measures of diversity, individual-based rarefaction (Krebs, 1989) for plant families of 281 randomly chosen tree individuals and for 2000 counted pollen grains (all on family level) per slope position as well as the calculation of Sørensen-Indices of similarity between vegetation and pollen rain family data were carried out using the program PAST (Hammer et al., 2001).

\subsection{Results}

The numbers of species, pollen taxa and trees as well as pollen families encountered are shown in Table 1, a pollen diagram with the most important pollen and spore taxa can be found in Appendix S3 (see (a) for percentage data and (b) for influx data). The species vs family richness curve in Fig. 3 shows that for this region the relationship between family and tree species is linear $(y=1.5 x+3.95 ; r=0.81, P<0.001)$. As the correlation between pollen taxa richness and tree species richness was only slightly higher $(r=0.82, P<0.001)$ but involved

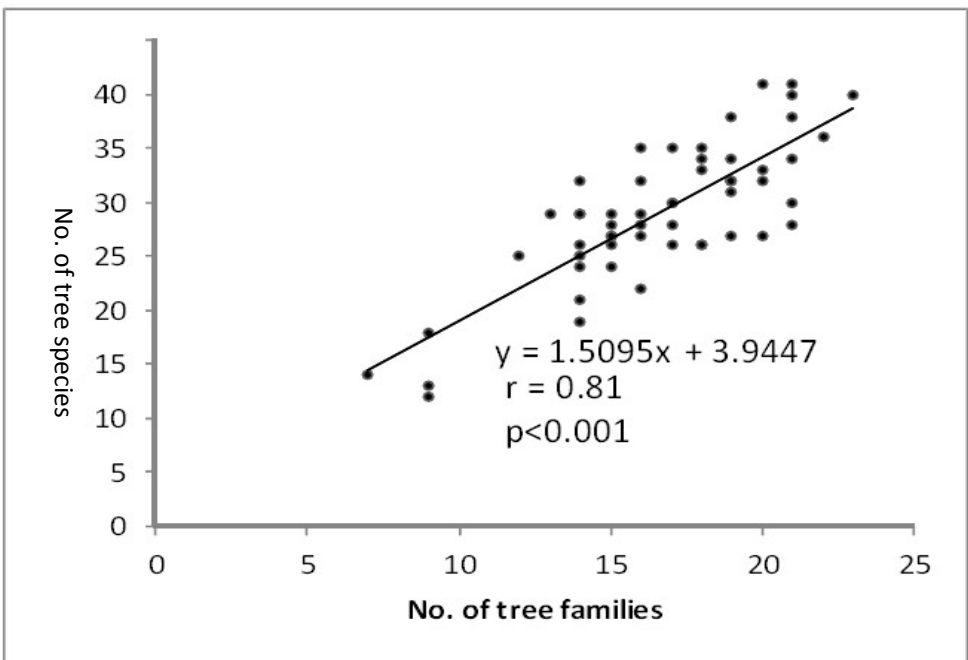

Figure 2 Correlation of the number of tree species to number of tree families for the vegetation of all three sites. much more insecurity in assigning plant to pollen taxa (see Discussion), we worked with family richness for both pollen and plant data. The pollen trap and vegetation analyses results from 53 samples were then divided into 18 groups, based on location (PMF, LMF or UMF) and inclination. The Sørensen indices comparing presenceabsence data for families/groups of families of plant and pollen taxa for each slope position are shown in Table 2. Highest similarity between pollen spectra and vegetation data are found within the ecosystem for all altitudes. In the PMF, highest similarity for the pollen rain of all slope 
positions was in vegetation of the lower slope. In the LMF, pollen rain diversity of al slope positions resembles the upper slope vegetation, and in the UMF, mid-slope vegetation diversity is most similar to the pollen rain of all altitudes. Furthermore, pollen spectra show comparatively high similarities ( $>0.6$ ) to vegetation of the adjacent ecosystems upslope (for PMF and LMF) and downslope (for UMF). Figure 3 shows species accumulation curves for individual-based rarefaction pollen data based on 2000 counted pollen grains per slope position. Also, individual-based rarefaction data for a random sample of 281 trees, corresponding to an area of $2400 \mathrm{~m}^{2}$ for vegetation data, is compared to the individual-based rarefaction for a random sample of 2000 counted pollen grains. General trends of diversity patterns with changing topography and altitude are visible, and the pollen data clearly represents the vegetation data on a family level. Specifically, plant and pollen richness at family level remain on a similar scale, but pollen richness is higher than tree richness at a family level for the UMF and the upper slope of the LMF, whereas it is lower at the mid-and lower slope positions of the LMF and in the PMF. The general pattern of the tree diversity of the UMF and PMF is repeated in the pollen data, as the lower slope has the highest diversity, followed by the mid-slope and upper slope. For the LMF, however, pollen data record highest diversity for the upper slope, followed by mid-slope and then lower slope, whereas the pattern of tree diversity is different, with highest values at the mid-slope and lowest values at the

Table 2 Sørensen's index of similarity for tree vegetation versus pollen rain data on family level for the different slope positions in each ecosystem. PMF = Premontane forest, LMF = Lower montane forest, UMF = Upper montane forest, LS = Lower slope, MS = Mid-slope, US = Upper slope. The highest value in each column is marked in dark grey.

upper slope positions.

Figure 4 shows box-

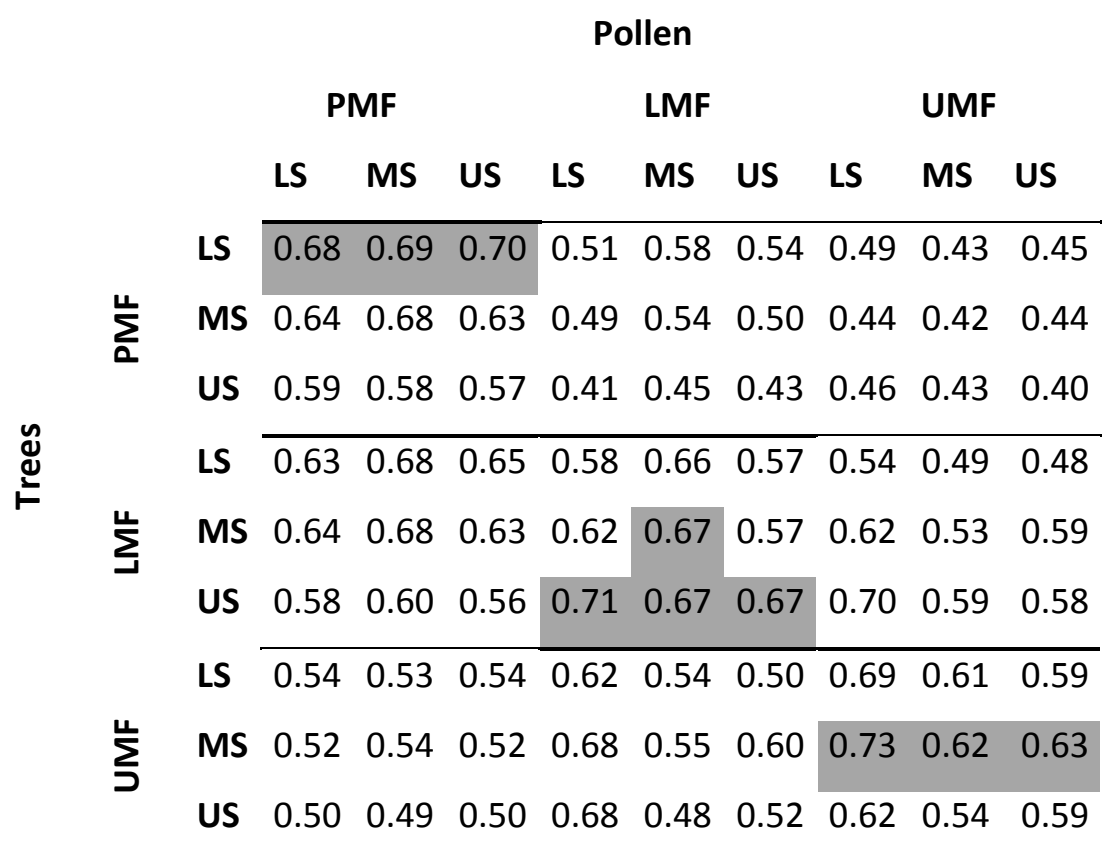
plots of the percentages of tree taxa at family level that were part of the pollen rain but were not recorded in vegetation of the plots. The proportions of external pollen taxa vary among sites (ca. $1-47 \%$ ) and are not clearly related

to a specific pattern of altitude or inclination, even though the variance is lower in samples of 
the UMF. ANOVAs and post-hoc Tukey's honest significance difference (HSD) tests show that significant differences exist only between the means of the LMF upper slope and LMF lower slope (difference $=24.45, P<0.05$ ).

\subsection{Discussion}

\subsubsection{Taxonomic surrogacy}

As a matter of course, taxonomic surrogacy, i.e. the use of higher-ranked systematic levels such as genera or families instead of species, is always applied when working with pollen data.
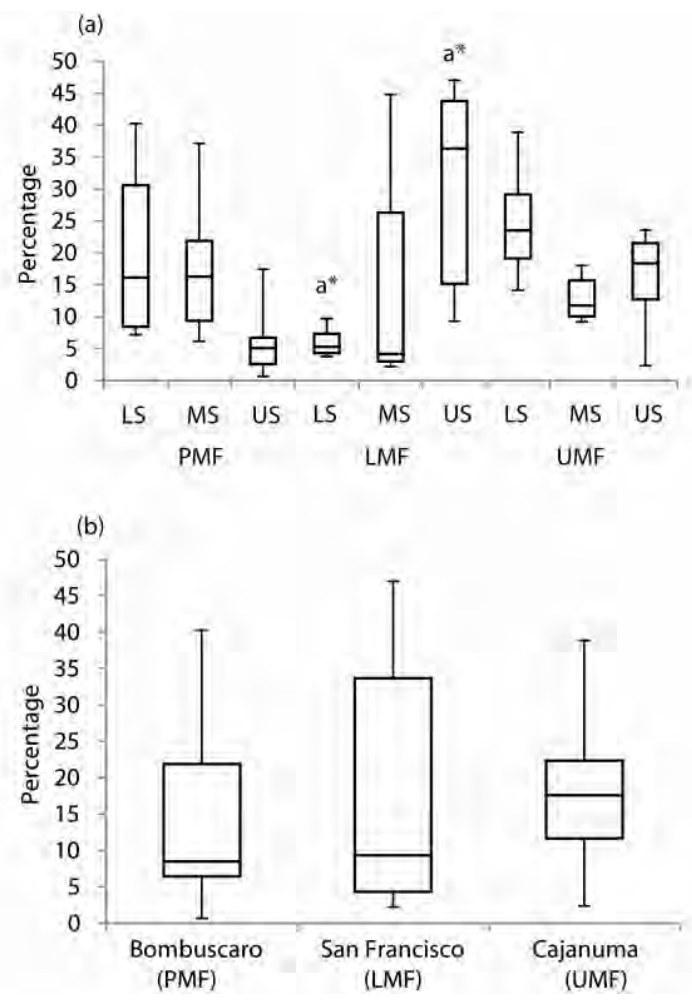

Figure 4 Box-plots of percentages of tree pollen taxa on family level that were found in the pollen rain but not in local vegetation of the plots (a) compiled results for data of the different slopes for one altitude. Tukey's honest significance difference (HSD) tests show significant differences for different slope positions within one site only between LMF upper slope and LMF lower slope $\left(^{\mathrm{a},{ }^{*}} \mathrm{P}\right.$ $<0.05)$ as well as between LMF US and PMF US $(P<0.05)$. (b) Compiled results for data from the three altitudinal zones. Tukey HSD tests show no significant differences between sites. $\mathrm{LS}=$ Lower slope, $\mathrm{MS}=$ Mid-slope, US = Upper slope, $\mathrm{PMF}=$ Premontane Forest (Bombuscaro), $\mathrm{LMF}=$ Lower montane forest (San Francisco), UMF = Upper montane forest (Cajanuma). show that there is a strong relationship between the diversity ofplant taxa on the species-level
In most cases, pollen grains can only be determined to genus or family level, sometimes even to a higher taxonomic level (e.g. Melastomataceae/Combretaceae, Moraceae/Urticaceae). This has the advantage that, despite of an overwhelming number of plant species, working with specified pollen taxa is still feasible and reliable results on environmental changes can still be obtained. Taxonomic surrogacy at family level seems to be the right choice for a comparison of pollen and plant taxa in the tropics, as previously suggested (Odgaard, 2001). In species rich regions, such as the Podocarpus National Park, pollen taxa represent groups of species or genera that are sometimes hard to identify. Moreover, many pollen taxa found in modern pollen rain have either not been described or it is not entirely clear which plant species belong to a specific pollen taxon. This raises the probability of false species assignments to a pollen taxon. Furthermore, our results clearly 

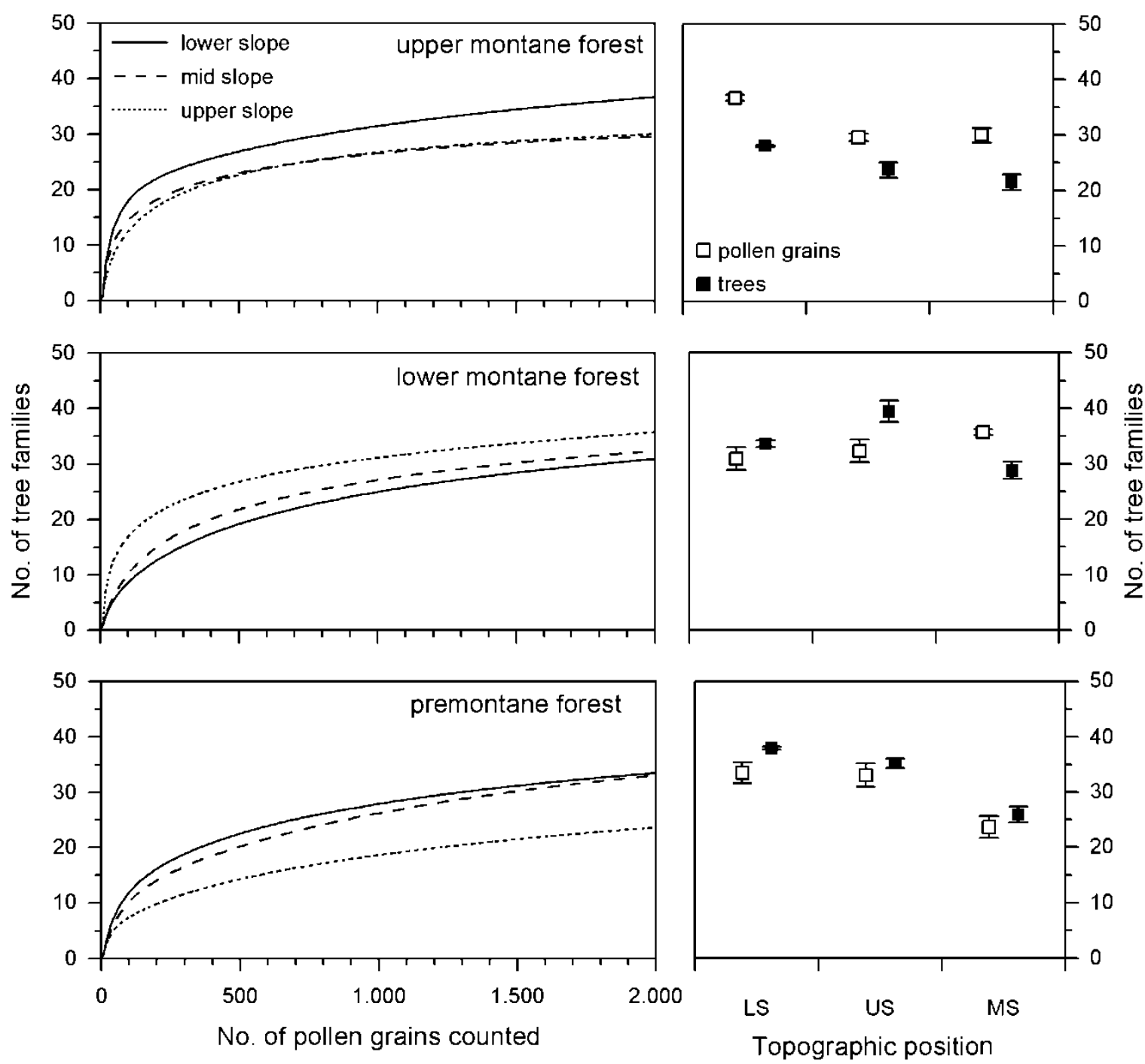

Figure 3 Family accumulation curves for pollen versus vegetation data of all slope positions. The rarefaction data for trees were obtained using an individual-based rarefaction (Krebs, 1989) based on 281 randomly selected individuals. For pollen data, the individual-based rarefaction is based on 2000 counted pollen grains for each slope position. LS = Lower slope, MS = Mid-slope, US = Upper slope. The left panel shows the accumulation curves for pollen grains and the right panel shows the expected number of families $( \pm S D)$ for $N=2000$ pollen grains and for $N=281$ trees for each slope position. 
to that at the family level which does not greatly differ to from the one of plant taxa that we assigned to pollen taxa. Additionally, the insecurity and difficulty in determination increases when working with fossil pollen types. The method of taxonomic surrogacy at family level has been proven to be reliable for the explanation of biodiversity patterns (e.g. La Torre-Cuadros et al., 2007; Leal et al., 2010) and the reconstruction of beta diversity (Terlizzi et al., 2008). However, generally, care should be taken when applying taxonomic surrogacy, as the fact that higher taxonomic levels as Linnean ranks are a product of phylogeny as well as historical determination processes that change over time (Bertrand et al., 2006) makes each case unique.

In our study area, we found a strong species/family relationship of ca. 1.5 tree species per family (Fig. 2). However, due to the reasons mentioned above and the fact that each region has a different species/family occurrence pattern, these results should not be directly transferred to other areas. Nevertheless, an index, once established for the present vegetation of a given region, could be transferred to historical pollen data by calculating backwards to obtain the family/species relationship for each sample. However, this should be treated with caution and further studies are necessary to test this method.

In answer to our first research question, we can state that the diversity of families/groups of families for some taxa is, especially for tropical vegetation, a sensible taxonomic parameter with which reliable results of plant and pollen data in relation to one another can be obtained. These relationships can be applied to fossil pollen data in order solve paleoecological problems related to diversity.

\subsubsection{Diversity, long-distance transport and evenness}

The rarefaction data (Fig. 2) shows, that tree and pollen diversity at family level display similar patterns at the different slope positions, with highest diversity occurring at the lower slopes and lowest diversity occurring at the upper slopes of UMF and PMF, respectively. Only in the LMF is diversity of pollen highest at the upper slope, whereas tree diversity is highest at the mid-slope position. However, generally, the differences between the sites are too small to be significant.

On a species-level, the tree vegetation along the broad altitudinal gradient from PMF to UMF shows a hump-shape diversity pattern with highest species number occurring at mid-altitudes (LMF, San Francisco) and decreasing diversity towards the PMF and UMF, which shows the lowest diversity (J. Homeier, unpublished). This same pattern can also be recognized in results of the rarefaction analysis of both pollen and vegetation data at family level. Thus, it can generally be stated that tree diversity and tree pollen diversity correspond very well to one another at family level, with mostly small differences when looking at higher pollen sums in the rarefaction analysis. As seen in Fig. 3, a high count of as much as 2000 pollen grains is a sensible database for 
estimation of biodiversity from pollen data, as the species accumulation curve does not reach a visible asymptote before this point, and at this point, plant and pollen diversity at family level have the same dimensions.

Tree diversity at family level is similar, although slightly higher than the corresponding pollen diversity in every case in the PMF and mostly higher in the LMF. Surprisingly, at sites of UMF and the upper slope of LMF, pollen diversity is higher than tree diversity. This can partly be explained by the strong winds with mean velocities of $8.2 \mathrm{~m}^{\mathrm{s}-1}$ which prevail on the eastern cordillera (Emck, 2007). These carry pollen over long distances, leading to an additional species, as the local flora is also present in the pollen record. In general, long-distance transport should not be underestimated when looking at pollen diversity, as previously suggested by authors working in tropical America (e.g. Bush and Rivera, 1998). In our record, especially taxa with a higher pollen dispersal capacity, e.g. Alnus, can be found in nearly every sample, even though the plant is not present in any of the plots. Figure 4 illustrates that varying proportions (1-50\%) of external pollen taxa at family level can be found in the pollen traps. This is not determined by slope position or altitude, but may be more due to local and regional vegetation patterns. We found that high percentages of external pollen taxa are mostly caused by high abundances of pollen taxa with high dispersal capacity, which are frequent in the regional vegetation but not in the specific plot, e.g. Moraceae/Urticaceae or Melastomataceae.

This relationship is also shown by the $\ \varnothing$ rensen indices comparing plant and pollen diversity data. Even though the highest resemblance is among samples of one altitudinal level, comparatively high similarities can also be found between vegetation and pollen rain data of different altitudes. For the PMF and LMF, data point to a down-drift of taxa from higher to lower altitudes, whereas in the UMF an up-drift is visible in the diversity data. Whereas the UMF sites in Cajanuma are more dominated by the strong SE trade winds, the lower sites of the San Francisco Valley (LMF) and Bombuscaro (PMF) have less dominant wind patterns. In the San Francisco area, a mountainvalley system (up-valley winds during the day and down-valley winds at night) with different seasonal patterns is observed. In July and August, the maximum wind speed is reached and $\mathrm{E}$ is the most frequent wind direction, whereas during fair weather (mostly during November and December) a moderate to fresh along-valley, downstream SW breeze is prevalent (Emck, 2007). For Bombuscaro, no wind-data have been measured, but the pattern seems to be even less uniform, with an adynamic along-valley system (Emck, 2007). A noticeable effect of wind on the pollen records in the Neotropics has also been reported in other studies for the region (Niemann et al., 2010) and elsewhere (e.g. Gosling et al. 2009). However, as Bush (2000) stated, even though these downslope movements can have an impact on diversity data, they do not account for high over-representation of abundant taxa in the altitudinal level further downwards. As can 
be seen in our data, other authors (Bush, 2000; Niemann et al., 2010) have shown up-slope transport of pollen taxa from lower altitudes, resulting in an over-representation of lowland taxa in the UMF and sub-páramo sites.

As many studies show (e.g. Jacobson and Bradshaw, 1981; Prentice, 1985), in historical records, distinctive sampling properties, such as basin size and sediment inflow, are very important factors that generally determine the pollen source area of a locality. Forest hollows are known to record environmental conditions on a very local scale, but with increasing basin size regional pollen represents an increasing proportion (Jacobson and Bradshaw, 1981). This fact is important to consider when comparing modern pollen rain to paleoecological archives in a more quantitative manner. As our pollen traps were placed immediately below the canopy, they precisely represent the local vegetation. This increases the probability of samples with high over-representation of single taxa, which in turn has the effect that the probability of detecting rare pollen taxa is decreased (Weng et al., 2006). This would thus lead to a decrease in pollen diversity in such a sample. Also, unlike in sediment deposits, pollen is fixed in the trap by the cotton and the glycerol once caught, and is not further transported. Thus, it should be noted that comparing pollen data from a sediment core and a pollen trap from the same vegetation type may lead to slightly different results with regard to pollen diversity (Jantz et al. 2013). In general, we can say, that even though we did not count more than one trap per plot, which may decrease representativeness of the vegetation in the pollen spectrum, the six replications for one slope position give a good impression of the variability in pollen spectra within one forest type.

The fact that we summed up all replicated plots for each slope position for vegetation and pollen data for the family accumulation curves and for the determination of Sørensen-indices, may have resulted in a larger pollen source area being covered by the pollen data, where consequently more rare taxa were recorded. On the other hand, the pattern may partly be because we only included trees in the data. Naturally, some pollen families that we assigned to 'tree families' may in reality reflect the occurrence of not recorded herb, shrub or epiphytic taxa of the same family, even though we tried to avoid this by excluding pollen types where we were sure that they only included herb taxa. This may especially have caused comparatively much higher diversity in pollen families of the UMF, which is closer to the upper forest limit and the páramo, where wind plays a stronger role. Especially in the páramo, total pollen abundance is generally lower, resulting in a detection of more rare taxa (Weng et al., 2006). Also in the UMF, individuals within a tree family are more evenly distributed in the vegetation and produce similar amounts of pollen, resulting in a more uniform pollen grain distribution. This pollen rain evenness leads to a better representation of pollen type richness, as all taxa are represented to a similar extent (Peros and Gajewski, 2008; Odgaard, 1999). Even though we tried to remove the effect of different plant 
distribution and pollen abundance patterns in the different vegetation types by summing the data of all plots for one slope position per altitude to obtain more representative results and greatly increase our total pollen count values, this method still does not completely resolve the problem of evenness. With respect to our second research question, we find that by using this method, the pollen data do generally reflect regional ecosystem diversity at family level and could thus be used for past diversity reconstructions. Nevertheless, the evenness-problem remains one of the biggest issues in diversity estimations using pollen data, and requires more intense research.

For our third research question, we can state that the degree of similarity of pollen and spore diversity in relation to tree diversity is highest within one vegetation type. However, due to longdistance-transport and uneven pollen and spore distribution, results are not sufficiently precise. Consequently, similarities between different slope positions and other vegetation types that are located nearby remain very high. We therefore recommend always combining the diversity and abundance analyses in order to gain reliable results for reconstruction of vegetation patterns during pollen anaylsis.

\subsection{Conclusion}

Taxonomic surrogacy at family level is a good approach for dealing with the comparison of modern tree pollen rain and tree vegetation data. There is a good correspondence of pollen rain to vegetation in the ecosystems assessed, but especially in the PMF and LMF, the data at family level are insufficient to determine changes due to topography. A comparison of rarefaction data indicates slightly higher family diversity in the tree vegetation than in the tree pollen data for the PMF and LMF, but higher diversity in pollen data for the UMF. This is to a large extent due to a higher evenness in the pollen data and stronger wind fields, and thus a larger amount of longdistance transported pollen in the UMF. However, a hump-shaped altitudinal diversity pattern can be recognized in both plant and pollen data at family level. In the UMF, most families are generally well represented, whereas in the PMF and LMF, over-representation of a few families and low pollen production of many less abundant pollen taxa lead to under-representation of many characteristic families for these ecosystems. Generally, major shifts in vegetation diversity and distribution can reliably be recorded at family level in pollen percentage as well as presenceabsence data. Detailed long-term studies are needed to enhance the knowledge on pollen productivity estimates and pollen distribution for tropical tree vegetation to be able to make more quantitative estimates of paleoecological patterns in tropical mountain diversity and distribution. 


\subsection{Acknowledgements}

The authors thank Corinna Brunschön, Fernando Rodríguez, Jaime Peña, Andrea and Stéphany Villota and Nixon Cumbicus for assistance in the field. The local managers of the FOR 816 are thanked for logistical support. We acknowledge Thomas Giesecke for valuable and inspiring scientific discussions on the subject. The authors are grateful to the Co-Editor Valério de Patta Pillar as well as to Gerald Islebe and an anonymous reviewer who helped to improve an earlier draft of this manuscript. This research has been funded by the DFG project FOR 816 (Grants BE2116/8-2 and HO3296/2-2).

\subsection{References}

APG (=The Angiosperm Phylogeny Group) III. 2009. An update of the Angiosperm Phylogeny Group classification for the orders and families of flowering plants: APG III. Botanical Journal of the Linnean Society, 161, 105-121.

Bendix, J., J. Homeier, E. Cueva Ortiz, P. Emck, S.-W. Breckle, M. Richter, and E. Beck. 2006. Seasonality of weather and tree phenology in a tropical evergreen mountain rain forest. International Journal of Biometeorology, 50, 370-384.

Bendix, J., R. Rollenbeck, M. Richter, P. Fabian, and P. Emck. 2008. Climate. Pages 63-73 in E. Beck, J. Bendix, I. Kottke, F. Makeschin, and R. Mosandl, editors. Gradients in a tropical mountain ecosystem of Ecuador. Springer, Berlin.

Berrio, J.-C., M. Arbeláez, J. Duivenvoorden, A. Cleef, and H. Hooghiemstra. 2003. Pollen representation and successional vegetation change on the sandstone plateau of Araracuara, Colombian Amazonia. Review of Palaeobotany and Palynology, 126, 163-181.

Bertrand, Y., F. Pleijel, and G. Rouse. 2006. Taxonomic surrogacy in biodiversity assessments, and the meaning of Linnaean ranks. Systematics and Biodiversity, 4, 149-159.

Birks, H. and J. Line. 1992. The use of rarefaction analysis for estimating palynological richness from Quaternary pollen-analytical data. The Holocene, 2, 1-10.

Brown, A. 1999. Biodiversity and pollen analysis: modern pollen studies and the recent history of a floodplain woodland in S. W. Ireland. Journal of Biogeography, 26, 19-32.

Bush, M., and C. Weng. 2007. Introducing a new (freeware) tool for palynology. Journal of Biogeography, 34, 377-380.

Bush, M. 2000. Deriving Response Matrices from Central American Modern Pollen Rain. Quaternary Research, 54, 132-143.

Bush, M., and R. Rivera. 1998. Pollen dispersal and representation in a neotropical rain forest. Global Ecology and Biogeography, 7, 379-392.

Bush, M., and R. Rivera. 2001. Reproductive ecology and pollen representation among neotropical trees. Global Ecology and Biogeography, 10, 359-367.

Colinvaux, P., and P. De Oliveira. 1999. Amazon pollen manual and atlas = Manual e atlas palinologico da Amazonia, Harwood Academic Publishers, Amsterdam.

Collins, A., and M. Bush. 2010. An analysis of modern pollen representation and climatic conditions on the Galapagos Islands. The Holocene, 21, 237-250.

Correa-Metrio, A., M. Bush, L. Perez, A. Schwalb, and K. Cabrera. 2011. Pollen distribution along climatic and biogeographic gradients in northern Central America. The Holocene, 21, 681692.

Davis, M. 1963. On the theory of pollen analysis. American Journal of Science, 261, 897-912.

Davis, O. 1984. Pollen frequencies reflect vegetation patterns in a great basin (U.S.A.) mountain range. Review of Palaeobotany and Palynology, 40, 295-315. 
Emck, P. 2007. A climatology of South Ecuador - With special focus on the Major Andean Ridgeas Atlantic-Pacific Climate Divide. PhD-thesis, University Erlangen-Nürnberg.

Giesecke, T., W. van der Knaap, and F. Bittmann, editors. 2010. Towards quantitative palynology: using pollen accumulation rates and models of pollen dispersal. Vegetation History and Archaeobotany, 19.

Gosling, W., F. Mayle, N. Tate, and T. Killeen. 2009. Differentiation between Neotropical rainforest, dry forest, and savannah ecosystems by their modern pollen spectra and implications for the fossil pollen record. Review of Palaeobotany and Palynology, 153, 7085.

Gosling, W., F. Mayle, N. Tate, N., and T. Killeen. 2005. Modern pollen-rain characteristics of tall terra firme moist evergreen forest, southern Amazonia. Quaternary Research, 64, 284297.

Grabandt, R. 1980. Pollen rain in relation to arboreal vegetation in the Colombian Cordillera Oriental. Review of Palaeobotany and Palynology, 29, 65-147.

Hammer, $\varnothing$., D. Harper, and P. Ryan. 2001. Past: Paleontological Statistics Software Package for Education and Data Analysis. Palaeontologia Electronica, 4, 1-9.

Hansen, B., D. Rodbell, G. Seltzer, B. Leon, K. Young, and M. Abbott. 2003. Late-glacial and Holocene vegetational history from two sites in the western Cordillera of southwestern Ecuador. Palaeogeography, Palaeoclimatology, Palaeoecology, 194, 79-108.

Homeier, J., F. Werner, R. Gradstein, S.-W. Breckle, and M. Richter. 2008. Potential vegetation and floristic composition of Andean forests in South Ecuador, with a focus on the RBSF. Pages 87-100 in E. Beck, J. Bendix, I. Kottke, F. Makeschin, and R. Mosandl, editors. Gradients in a tropical mountain ecosystem of Ecuador. Springer, Berlin.

Homeier, J., S.-W. Breckle, S. Günter, R. Rollenbeck, and C. Leuschner. 2010. Tree diversity, forest structure and productivity along altitudinal and topographical gradients in a species-rich Ecuadorian montane rainforest. Biotropica 42, 140-148.

Jacobson, G., and R. Bradshaw. 1981. The selection of sites for paleovegetational studies. Quaternary Research, 16, 80-96.

Jantz, N., J. Homeier, S. León-Yánez, A. Moscoso and H. Behling. 2013. Trapping pollen in the tropics - Comparing modern pollen rain spectra of different pollen traps and surface samples across Andean vegetation zones. Review of Palaeobotany and Palynology 193:5769.

Jørgensen, P., and S. León-Yánez. 1999. Catalogue of the vascular plants of Ecuador. Monogr. Syst. Bot. Missouri Bot. Gard. 75: i-viii, 1-1182.

Jørgensen, P., and C. Ulloa Ulloa. 1994. Seed plants of the High Andes of Ecuador - A checklist. AAU Reports 34, 1-443. Aarhus University Press.

Krebs, C. 1989. Ecological Methodology, Harper and Row, New York.

Kuentz, A., A. de Mera, M.-P. Ledru, and J.-C. Thouret. 2007. Phytogeographical data and modern pollen rain of the puna belt in southern Peru (Nevado Coropuna, Western Cordillera). Journal of Biogeography, 34, 1762-1776.

La Torre-Cuadros, M., S. Herrando-Pérez, and K. Young. 2007. Diversity and structural patterns for tropical montane and premontane forests of central Peru, with an assessment of the use of higher-taxon surrogacy. Biodiversity and Conservation, 16, 2965-2988.

Leal, I., A. Bieber, M. Tabarelli, and A. Andersen. 2010. Biodiversity surrogacy: indicator taxa as predictors of total species richness in Brazilian Atlantic forest and Caatinga. Biodiversity and Conservation, 19, 3347-3360.

Melief, A.B. 1984. Comparison of vegetation and pollen rain on the Buritaca-la Cumbre transect (Sierra Nevada de Santa Marta, Colombia). Pages 547-559 in Van der

Hammen, T., Rangel, O. and A. Cleef, editors. Studies on tropical Andeanecosystems. J. Cramer (Borntraeger), Berlin-Stuttgart.

Moser, G., D. Hertel, and C. Leuschner. 2007 Altitudinal Change in LAl and Stand Leaf Biomass 
In Tropical Montane Forests: a Transect Study in Ecuador and a Pan-Tropical Meta Analysis. Ecosystems, 10, 924-935.

Niemann, H., C. Brunschön, and H. Behling. 2010. Vegetation/modern pollen rain relationship along an altitudinal transect between 1920 and $3185 \mathrm{~m}$ a.s.l. in the Podocarpus National Park region, southeastern Ecuadorian Andes. Review of Palaeobotany and Palynology, $159,69-80$.

Odgaard, B. 1999. Fossil pollen as a record of past biodiversity. Journal of Biogeography, 26, 7-17.

Odgaard, B. 2001. Palaeoecological perspectives on pattern and process in plant diversity and distribution adjustments: a comment on recent developments. Diversity and Distributions, 7, 197-201.

Olivera, M., J. Duivenvoorden, and H. Hooghiemstra. 2009. Pollen rain and pollen representation across a forest-páramo ecotone in northern Ecuador. Review of Palaeobotany and Palynology, 157, 285-300.

Ortuño, T., M.-P. Ledru, R. Cheddadi, A. Kuentz, C. Favier, and S. Beck. 2011. Modern pollen rain, vegetation and climate in Bolivian ecoregions. Review of Palaeobotany and Palynology, $165,61-74$.

Peros, M., and K. Gajewski. 2008. Testing the reliability of pollen-based diversity estimates. Journal of Paleolimnology, 40, 357-368.

Prentice, I. 1985. Pollen representation, source area, and basin size: Toward a unified theory of pollen analysis. Quaternary Research, 23, 76-86.

Rangel-Churio, J.O.. 2005. Lluvia de polen a lo largo de los transectos del macizo del Tatamá. La Cordillera Occidental colombiana- Transecto de Tatamá. Pages 711-755 in Van der Hammen, Rangel, O., and A. Cleef, editors. Studies on Tropical Andean Ecosystems. Cramer/Bornträger, Berlin-Stuttgart.

Roubik, D., and J. Moreno. 1991. Pollen and Spores of Barro Colorado Island. Missouri Botanical Garden, St. Louis, Missouri.

Salgado-Labouriau, M. 1979. Modern pollen deposition in the Venezuelan Andes. Grana, 18, 5368.

Terlizzi, A., M. Anderson, S. Bevilacqua, S. Fraschetti, M. Włodarska-Kowalczuk, and K. Ellingsen. 2008. Beta diversity and taxonomic sufficiency: Do higher-level taxa reflect heterogeneity in species composition? Diversity and Distributions, 15, 450-458.

Urrego, D., M. Silman, A. Correa-Metrio, and M. Bush. 2011. Pollen-vegetation relationships along steep climatic gradients in western Amazonia. Journal of Vegetation Science, 22, 795-806.

van der Knaap, W. 2009. Estimating pollen diversity from pollen accumulation rates: a method to assess taxonomic richness in the landscape. The Holocene, 19, 159-163.

Weng, C., M. Bush, and A. Chepstow-Lusty. 2004. Holocene changes of Andean alder (Alnus acuminata) in highland Ecuador and Peru. Journal of Quaternary Science, 19, 685-691.

Weng, C., M. Bush, and M. Silman. 2004. An analysis of modern pollen rain on an elevational gradient in southern Peru. Journal of Tropical Ecology, 20, 113-124.

Weng, C., H. Hooghiemstra, and J. Duivenvoorden. 2007. Response of pollen diversity to the climate-driven altitudinal shift of vegetation in the Colombian Andes. Philosophical Transactions of the Royal Society B: Biological Sciences, 362, 253-262.

Weng, C., H. Hooghiemstra, and J. Duivenvoorden. 2006. Challenges in estimating past plant diversity from fossil pollen data: statistical assessment, problems, and possible solutions. Diversity and Distributions, 12, 310-318.

Willis, K., L. Gillson, T. Brncic, and B. Figueroa Rangel. 2005. Providing baselines for biodiversity measurement. Trends in Ecology \& Evolution, 20, 107-108.

Willis, K., L. Gillson, and S. Knapp. 2007. Biodiversity hotspots through time: an introduction. Philosophical Transactions of the Royal Society B: Biological Sciences, 362, 169-174.

Witte, H. 1994. Present and past vegetation and climate in the Northern Andes (Cordillera Central, Colombia): A quantitative approach. PhD-Thesis. University of Amsterdam. 
Wolf, K., E. Veldkamp, J. Homeier, and G. Martinson. 2011. Nitrogen availability links forest productivity, soil nitrous oxide and nitric oxide fluxes of a tropical montane forest in southern Ecuador. Global Biochemichal Cycles, 25, GB4009. 


\section{Supporting information}

Additional supporting information may be found in the online version of this article and in the Appendix of this doctoral thesis.

Appendix S1 List of all plots with topographic information (see Appendix 3 of this thesis)

Appendix S2 List of all recorded plant and pollen and spore taxa with their designation (tree/non-tree) (see Appendix 4 and 5 of this thesis)

Appendix S3 Pollen diagram of the most important pollen and spore taxa. (a) Percentage data, (b) influx data (see Appendix 6 of this thesis for a diagram of all pollen and spore taxa encountered) 


\section{CHAPTER 4}

Trapping pollen in the tropics - Comparing modern pollen rain spectra of different pollen traps and surface samples across Andean vegetation zones

Nele Jantz ${ }^{1}$, Jürgen Homeier ${ }^{2}$, Susana León-Yánez ${ }^{3}$, Alejandra Moscoso ${ }^{3}$, \& Hermann Behling ${ }^{1}$

${ }^{1}$ Department of Palynology and Climate Dynamics, Albrecht-von-Haller Institute for Plant Sciences, University of Göttingen, 37073 Göttingen, Germany

${ }^{2}$ Department of Plant Ecology, Albrecht-von-Haller Institute for Plant Sciences, University of Göttingen, 37073 Göttingen, Germany

${ }^{3}$ Herbario QCA, Departamento de Ciencias Biológicas, Pontificia Universidad Católica del Ecuador, Quito, Ecuador 


\section{Key words}

Modern pollen rain, tropical mountain forest, páramo, Behling trap, modified Oldfield trap

\section{Abstract}

The analysis of modern pollen rain is an important prerequisite for detailed and comprehensive studies on fossil pollen assemblages, as it is necessary for obtaining valuable information about present pollen spectra in a more quantitative way. At present, several sampling media are used for modern pollen rain collection in tropical environments, without knowing a lot about their trapping properties. We compared modern pollen rain spectra of different pollen rain sampling media along an altitudinal gradient from ca. 1000 to ca. 3300 m a.s.l. in southern Ecuador. The vegetation types covered are premontane forest, lower montane forest, upper montane forest and páramo. Pollen assemblage composition, representation, diversity and palynological abundance in the modern pollen spectra of Behling traps, modified Oldfield traps, reference traps and soil samples were assessed in comparison to the vegetation. All sampling media showed distinguishable pollen spectra for each vegetation type. For the Páramo, the most characterising taxa are Poaceae and Melastomataceae, accompanied by other, less frequent taxa such as Arcytophyllum, Valeriana and Ericaceae. The pollen spectrum of the upper montane forest is dominated by Melastomataceae, Hedyosmum and Weinmannia. The lower montane and premontane forests both have similar spectra, with high proportions of Moraceae/Urticaceae, Melastomataceae, Alchornea and Cecropia. Soil samples had a bias towards an overrepresentation of pollen and spore taxa with a thick exine, such as Poaceae, whereas taxa with fragile pollen grains, as Moraceae/Urticaceae, were represented to a lesser extent than in the pollen traps. Behling traps and modified Oldfield traps show similar patterns in taxa composition, pollen accumulation rates and pollen taxa proportions, as well as in representation of pollen spectra in comparison with the vegetation. However, especially in the páramo samples, modified Oldfield traps were disintegrated after one year in the field, due to temporarily dry and windy conditions, as well as strong radiation. We therefore recommend the use of Behling traps for the collection of modern pollen rain in areas with open vegetation, which are subjected to drought periods and strong radiation. In forested areas, modified Oldfield and Behling traps show similar results.

\subsection{Introduction}

The understanding of the modern pollen rain - vegetation is crucial for a comprehensive analysis of processes and patterns of past ecosystem and climate dynamics using pollen data. The study of 
modern pollen rain - vegetation relationships has had a long and diverse history which started off in Europe in the $19^{\text {th }}$ century (Giesecke et al., 2010). The establishment of the European pollen monitoring program resulted in the development of increasingly advanced and more comprehensive studies on modern pollen rain (Hicks et al., 1996). In Europe, Tauber traps (Tauber, 1974) are the most commonly used pollen rain collectors and serve in their modified way as a standardised model in the European pollen monitoring programme (http://www.pollentrapping.net, e.g. Hicks et al., 2001). In the Neotropics, investigations into modern pollen - vegetation relationships started off in the 1970s (Flenley, 1973; SalgadoLabouriau, 1979). However, in the tropics, the quantity of heavy rainfall in some regions meant that Tauber traps were inappropriate for trapping due to flooding, and the incapability to cope with large quantities of water (Flenley, 1973).

Therefore, Tauber traps were rejected as a standard pollen trap model in very humid areas, where

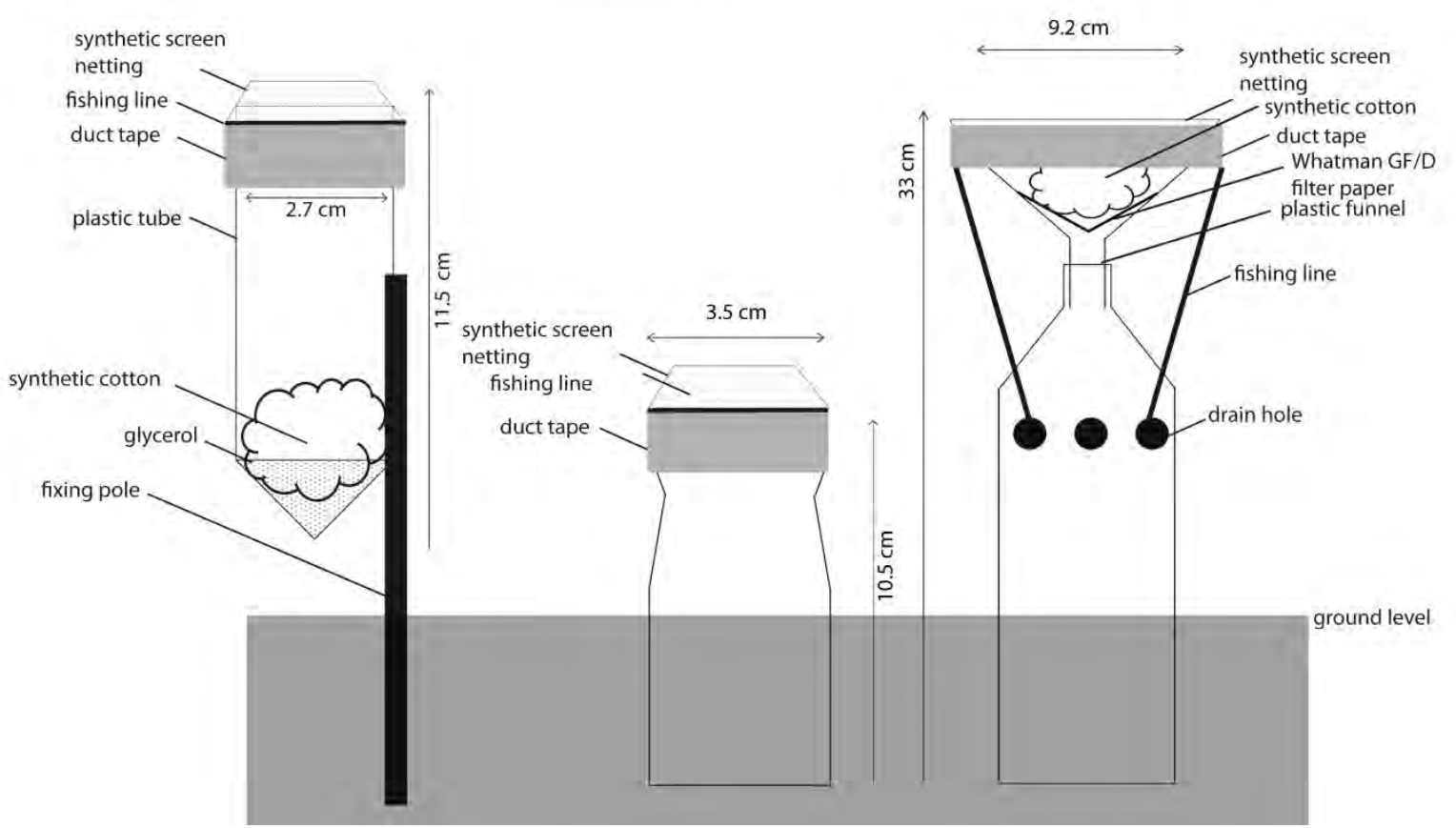

Figure 1. Cross-sectional views of the three pollen traps used in this study. (a) Behling trap, (b) reference trap, (c) modified Oldfield trap (modified after Bush, 1992).

the Oldield trap (Flenley, 1973) and later the Behling trap (Behling, et al., 2001) became frequently used trap types.

In 1973, Flenley first published data on modern pollen rain from the tropics which was collected in a trap designed by Oldfield. It consisted of a plastic funnel with a Whatman GF/B glass filter attached to it. The filter was covered by de-oiled acetate yarn and a mosquito net was placed over it to prevent bigger particles to fall in. The trap was put onto a conical flask which was filled by 
distilled water to assure a good moisture-balance. This model of the Oldfield trap has been modified by Bush (1992) who used viscose rayon staple instead of de-oiled acetate yarn, as it is more easily purchased and is dissolved during standard lab procedures and replaced the conical flask by a bottle with drain holes near the top (Figure 1b). Gosling et al. (2003) further simplified the design by replacing the bottle by a stake. The modified Oldfield pollen trap is the most widespread pollen trap that has been used for assessing modern pollen rain of tropical rainforests in Panama and Costa Rica (Bush and Rivera, 1998, 2001; Bush, 2000), as well as mountain rainforest and páramo vegetation in northern Ecuador (Olivera et al., 2009), rainforest, savannah, and dry forest ecosystems in Amazonia (Bush et al., 2001; Gosling et al., 2005, 2009; Burn et al., 2010; Jones et al., 2011), and pollen diversity of habitats on the Galapagos islands (Collins and Bush, 2010).

A second model of a pollen trap used for the study of pollen rain in tropical environments was developed by Behling and first published in 2001 (Behling et al., 2001). It consists of a plastic tube which is filled with synthetic cotton and liquid glycerol and covered by a mosquito net (Fig. 1a). It has served for the analysis of modern pollen rain in the tropical mountain rainforest of South Ecuador (Niemann et al., 2010, Jantz et al., see chapter 3), Panama, Colombia, and Brazil (Behling, unpublished).

Modern pollen rain analyses from the temperate zone demonstrated that different sampling media may affect taxonomic composition of pollen spectra and their proportions on a noteworthy level, especially when looking at the differences between moss or soil samples and pollen traps. Studies from the temperate regions have mostly assessed the differences in pollen recording of moss samples and Tauber traps (Cundill, 1991; Fall, 1992; Pardoe et al., 2010; Lisitsyna et al., 2011). Cundill (1991) observed that moss records the modern pollen rain in a different way than do the Tauber traps. He concluded that the lack in precision of sampling and variability in moss growth and sedimentation rates are responsible factors. Fall (1992) discovered that moss polsters and Tauber traps both record the local vegetation more accurately than do lake surface sediments. He further detected that moss polsters collect higher amounts of Pinaceae pollen, whereas in the Tauber traps, pollen of insect pollinated plants is increased, possibly due to the introduction of insects into the traps. Similar findings were reported by Lisistyna et al. (2011). They found a bias towards higher percentages of shrubs, herbs and Cyperaceae and lower values of tree pollen in the Tauber traps. Pardoe et al. (2010) discovered that moss samples correspond best to pollen deposition of two or more years in the pollen traps. They stated that pronounced regional differences occur. 
However, because of other environmental conditions, floristic differences and different pollen production patterns in tropical taxa, these studies can only be very indirectly compared to tropical modern pollen rain collection.

Also, many times, soil samples are analysed instead of moss polsters, due to the lack of terrestrial mosses in some ecosystems (Wilmshurst and McGlone, 2005; Ortuño et al., 2011).

Studies comparing the pollen collection characteristics of different trapping media in the tropics are scarce and different trap types have never been compared to each other. Olivera et al. (2009) compared modified Oldfield traps to moss samples in the páramo of northern Ecuador. However, their approach was different, as for one moss sample at least 10 subsamples were mixed to obtain a broader picture of the surrounding vegetation.

In this study, we provide the first assessment of modified Oldfield traps and Behling traps, which are the two pollen trap models most frequently used for the analysis of modern pollen rain spectra in tropical humid environments. Furthermore, we include an assessment of soil samples and reference traps to give a comprehensive overview of the similarities and differences of diverse sampling media for modern pollen rain composition and its proportional distribution in the Andean mountain vegetation of South Ecuador. We selected sites along an altitudinal gradient from ca. $1000 \mathrm{~m}$ a.s.l. to ca. $3300 \mathrm{~m}$ a.s.l. to cover the wide range of vegetation types, including premontane forest, lower montane forest, upper montane forest and páramo. All of these vegetation types are of substantial importance for palaeoecological studies that deal with the long-term forest dynamics of the northern to central Andes region. We especially focused on the páramo, as this region has received comparably little attention in terms of annual pollen rain collection, but is at the same time of major importance for the recording of past environmental changes of the high Andes region (e.g. Jantz and Behling, 2011; Brunschön and Behling, 2009; Hansen et al., 2003).

In this study, we focus on answering the following research questions:

1. To what extent do different pollen trap types and soil samples collect pollen rain in a different way and how is this reflected in the data?

2. Which pollen trap is most suitable for which tropical vegetation type?

\subsection{Study sites}

\subsubsection{Climate}

All sites are located in the area of the Podocarpus National Park and the San Francisco biological reserve in the provinces of Loja and Zamora-Chinchipe in the Eastern Andean Cordillera del 
Consuelo in South Ecuador (Fig. 2a). The study sites are located along an altitudinal gradient of ca. $2500 \mathrm{~m}$. The altitudinal gradient translates to a climate range of $0.61{ }^{\circ} \mathrm{C}$ per $100 \mathrm{~m}$ elevation (Bendix et al., 2008), and ca. 2000 to up to more than $6000 \mathrm{~mm}$ pa precipitation (Bendix et al., 2006). The climate of the research area is in general tropical humid with a wet season occurring from April to July and a slightly drier season from September to December (Bendix et al., 2006; Emck, 2007). The wind system is dominated by the tropical trade winds with strong easterlies throughout the year (Beck et al., 2008). However, local climatic conditions may differ due to microclimatic influence caused by topography.

\subsubsection{Vegetation}

There are four vegetation types encompassed by the transect: 1) Páramo, 2) Upper montane forest, 3) Lower montane forest and 4) Premontane forest.
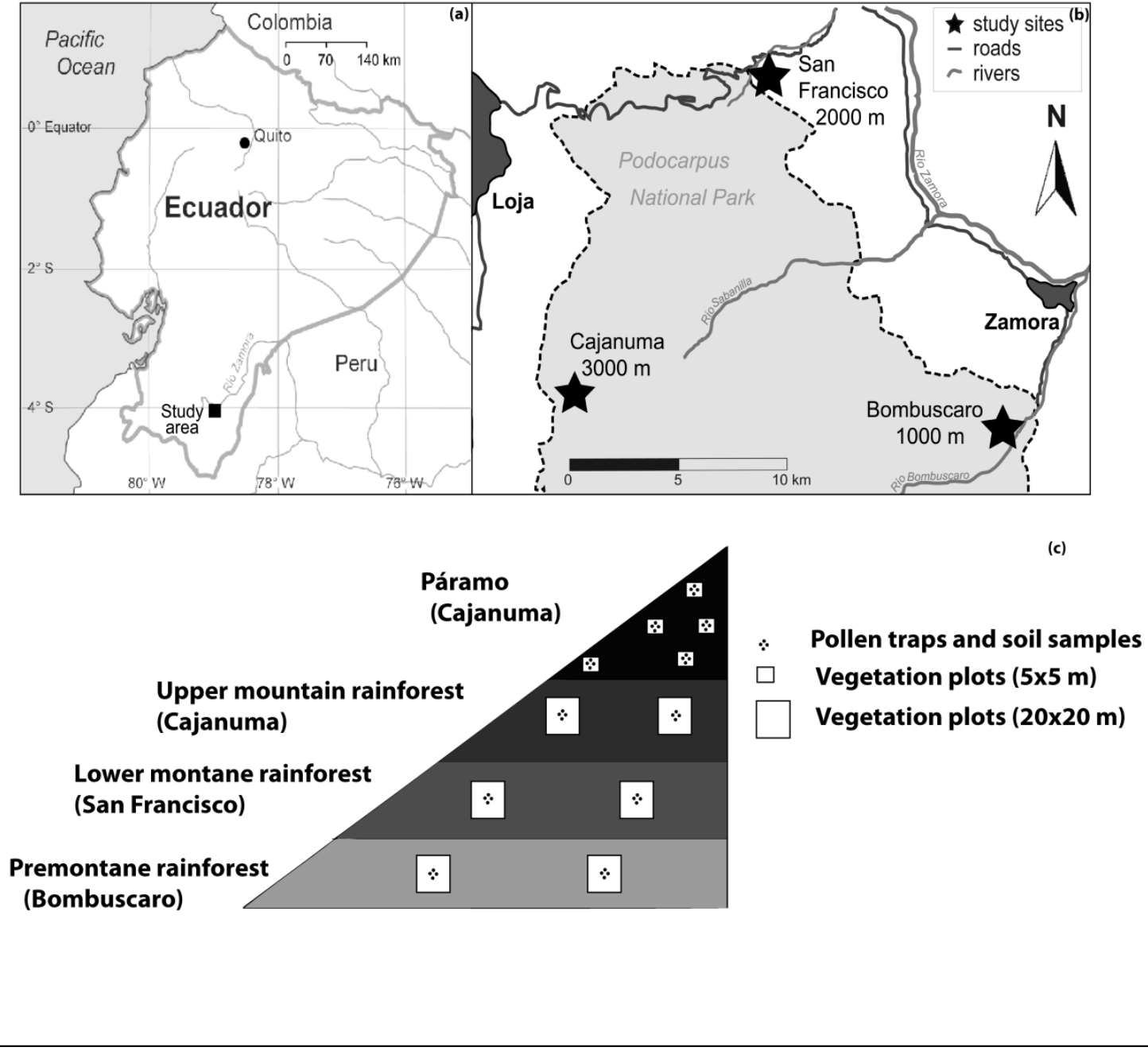

Figure 2. (a) Ecuador and the location of the study area. (b) Location of the study sites in the study area. (c) Sampling design of the experiment. We established five $25 \mathrm{~m}^{2}$ plots on the páramo-sites and two $400 \mathrm{~m}^{2}$ plots on each of the forested sites of upper montane forest, lower montane forest and premontane forest. We distributed one trap of each type in the centre of each plot and collected soil samples close to the traps. 


\section{Premontane forest (PMF)}

The lowermost site, Bombuscaro, is situated at $900-1100 \mathrm{~m}$ a.s.l.. It is covered by premontane forest (PMF), with tall trees reaching heights up to $40 \mathrm{~m}$. The most common tree families are Fabaceae, Melastomataceae, Moraceae, Myristicaceae, Rubiaceae and Sapotaceae (Homeier et al., 2008).

\section{Lower montane forest (LMF)}

The lower montane forest (LMF) at 1900 - $2100 \mathrm{~m}$ a.s.I. (San Francisco) is covered by trees of up to $22 \mathrm{~m}$ height. Here, tree species of the families Euphorbiaceae, Lauraceae, Melastomataceae and Rubiaceae dominate the vegetation (Homeier et al., 2008).

\section{Upper montane forest (UMF)}

Characteristic arboreal families of the upper montane forest (UMF) at Cajanuma (2800 - $2900 \mathrm{~m}$ a.s.I.) are Aquifoliaceae, Clusiaceae, Cunoniaceae, Lauraceae and Melastomataceae (Homeier et al., 2008). The trees at this altitude do not grow higher than 8-10 $\mathrm{m}$.

\section{Páramo}

The uppermost site is the páramo (PAR) at Cajanuma, which is situated above the upper forest line, which is defined as the present limit of tree occurrence. It is dominated by herbs and small shrubs up to $1 \mathrm{~m}$. The most important plant families of this vegetation type are Poaceae, Asteraceae, Ericaceae, Bromeliaceae, and Rosaceae, as well as Hypericaceae and Rubiaceae. Another important feature of this vegetation type is the abundance of Bryophytes (up to $40 \%$ cover in the vegetation plots).

\subsection{Methods}

\subsubsection{Vegetation analysis}

For the forested sites at PMF, LMF and UMF plots of a size of $20 \times 20 \mathrm{~m}$ were established. All tree species with a DBH (diameter at breast height) $\geq 5 \mathrm{~cm}$ were recorded. For the páramo sites, plots were smaller with a size of $5 \times 5 \mathrm{~m}$, as here, plant composition changes on a much smaller scale. Here, all vascular plant species were identified and their abundance (\% of the total coverage) was recorded. For mosses and bare soil, total coverage was documented. For family classification, we followed (APG (=The Angiosperm Phylogeny Group) III, 2009). 


\subsubsection{Pollen trap design and sampling}

We distributed three different types of pollen traps in the field for one year from October 2010 to October 2011 (see Fig. 2c and Table 1 for details). The trap models used were: 1) Modified Oldfield traps (Fig. 1C), 2) Behling traps (Fig. 1a) and 3) Reference traps (Fig. 1b). All three pollen trap types were distributed next to one another in the middle of each plot. Additionally, for each plot a soil sample was taken close to the traps to record the pollen composition of the surface soil.

Table 3 Geographical location, size, and dates of pollen trap distribution as well as recollection for the study sites.

\begin{tabular}{cccccccc}
\hline $\begin{array}{c}\text { Location } \\
\text { (Vegetation) }\end{array}$ & Position & $\begin{array}{c}\text { Date } \\
\text { distributed }\end{array}$ & $\begin{array}{c}\text { Date } \\
\text { recollected }\end{array}$ & $\begin{array}{c}\text { UTM 17 } \\
\mathbf{M} \text { coord. } \\
(\mathbf{N})\end{array}$ & $\begin{array}{c}\text { UTM 17 } \\
\mathbf{M} \text { coord. } \\
(\mathbf{E})\end{array}$ & $\begin{array}{c}\mathbf{m} \\
\text { a.s.I. }\end{array}$ & $\begin{array}{c}\text { Plot } \\
\text { area } \\
\text { (m) }^{\mathbf{2}}\end{array}$ \\
\hline & Slope 1 & 14.10 .2010 & 16.10 .2011 & 9543944 & 704434 & 3224 & 25 \\
Cajanuma & Slope 2 & 14.10 .2010 & 16.10 .2011 & 9543993 & 704330 & 3244 & 25 \\
(Páramo) & Valley 1 & 14.10 .2010 & 16.10 .2011 & 9543888 & 704335 & 3237 & 25 \\
& Valley 2 & 14.10 .2010 & 16.10 .2011 & 9543919 & 704330 & 3238 & 25 \\
& Valley 3 & 14.10 .2010 & 16.10 .2011 & 9543941 & 704360 & 3240 & 25 \\
\hline Cajanuma & Upper Slope 3 & 10.10 .2010 & 14.10 .2011 & 9545640 & 702192 & 2869 & 400 \\
(UMF) & Mid-Slope 4 & 10.10 .2010 & 14.10 .2011 & 9545040 & 702595 & 2900 & 400 \\
\hline San Francisco & Upper Slope 3 & 03.10 .2010 & 20.10 .2011 & 9560140 & 713666 & 2089 & 400 \\
(LMF) & Lower Slope 2 & 02.10 .2010 & 20.10 .2011 & 9560310 & 713655 & 1993 & 400 \\
\hline Bombuscaro & Upper Slope 3 & 06.10 .2010 & 12.10 .2011 & 9544990 & 725729 & 1072 & 400 \\
(PMF) & Lower Slope 2 & 06.10 .2010 & 12.10 .2011 & 9544600 & 725315 & 1069 & 400 \\
\hline
\end{tabular}

\section{Modified Oldfield traps}

The first pollen trap model was the modified Oldfield trap developed by Bush (1992), which has been used extensively in pollen rain studies throughout the Neotropics. It consists of a Whatman filter as a pollen collector which is glued to a plastic funnel with a diameter of $9.2 \mathrm{~cm}$. For additional pollen collection, rayon fibre is placed onto the filter. The trap is attached to a bottle with holes in it to ensure the water-outflow, and covered by a screen mesh for protection against smaller animals and litter.

\section{Behling traps}

The second pollen trap model was developed by Behling (Behling et al., 2001, see also Niemann et al., 2010 and, more detailed, Jantz et al., chapter 3). For this trap, rayon fibre is placed into a plastic tube with a diameter of $2.7 \mathrm{~cm}$. The tube is then filled with about $5 \mathrm{ml}$ of liquid glycerol. This medium has a higher density than water and thus creates a separate liquid phase at the 
bottom of the tube. Therefore, during heavy rainfalls, water can flow out over the top of the tube, without removing the pollen which is trapped in the glycerol and synthetic rayon fibre. For protection against smaller animals and litter the trap is covered by a screen mesh.

\section{Reference traps}

The third pollen trap type was a reference to record the effect of not using a specific pollen collector tool such as synthetic cotton or filters. This trap consisted of a plastic bottle with an opening diameter of $3.5 \mathrm{~cm}$ which was dug into the ground and covered by a screen mesh to protect it against smaller animals and litter.

\subsubsection{Pollen analysis}

Pollen was extracted from the Behling traps and from the reference traps by centrifuging and sieving the samples. Afterwards, acetolysis was carried out on the samples to dissolve cellulose material and to stain the pollen residues. For the modified Oldfield traps and the surface-samples, HF-treatment was applied to the samples before acetolysis. For the calculation of concentration values and pollen accumulation rates, three tablets of $20848 \pm 1546$ exotic Lycopodium clavatum spores were added to each sample (with the exception of the Behling traps of the PMF, where only two tablets were used). Samples were counted to a minimum of 300 pollen grains. However, samples with a very high pollen concentration were counted to a minimum of 100 Lycopodium spores to ensure the reliability of concentration values and pollen accumulation rates (see Maher, 1981). Spores were excluded from the pollen sum. For pollen determination, we used the reference collections of Ecuador and Brazil of the Department of Palynology and Climate Dynamics, University of Göttingen. Furthermore, we used literature (Hooghiemstra, 1984; Roubik and Moreno, 1991; Colinvaux and De Oliveira, 1999) and the electronic pollen keys of Ecuador, southern Brazil (Department Palynology and Climate Dynamics, Göttingen) and the Neotropics (Bush and Weng, 2007).

\subsubsection{Data analysis}

Pollen diagrams were obtained using the programs TILIA and TILIAGRAPH (Grimm, 1987). We calculated Euclidean distances for the species abundance in the studied vegetation types (basal area of trees for the UMF, LMF and PMF plots and percentage of total vegetation cover for the páramo samples) compared to the pollen percentage values for selected taxa, as well as the individual-based rarefaction (Krebs, 1989) for a sum of 280 counted pollen grains with the program PAST (Hammer et al., 2001). This method is used for the comparison of taxa diversity between different sites at a specified number of individuals encountered. Furthermore, we 
carried out a PCA for the data of each vegetation type using CANOCO and CanoDraw (terBraak and Šmilauer, 2002). Before doing so, we first carried out a DCA to determine the length of the environmental gradient, which measures the beta diversity in community composition of our datasets (terBraak and Šmilauer, 2002). As it was lower than 2.5 for each dataset analysed, we could assume that the taxa responses correspond to a linear model and chose principal components analysis (PCA). For the PCA, we used relative pollen abundance data of all taxa which were present with least one value of $0.6 \%$ in the specific vegetation type. We did not transform or weigh the data further. We centred for species and samples. Only the species with a fit of $>50 \%$ are shown in the diagram.

\subsubsection{Association and representation indices}

For the calculation of association (A), over-representation $(\mathrm{O})$ and under-representation (U) indices which compare pollen and plant presence-absence data, we used the following equations which were first described by Davis (1984):

$\mathrm{A}=\mathrm{B} 0 /(\mathrm{PO}+\mathrm{P} 1+\mathrm{B} 0)$

$\mathrm{U}=\mathrm{P} 1 /(\mathrm{P} 1+\mathrm{B} 0)$

$\mathrm{O}=\mathrm{PO} /(\mathrm{PO}+\mathrm{BO})$

With $\mathrm{BO}$ being the number of samples where the pollen type is present in both the pollen sample and the associated vegetation plot, $\mathrm{PO}$ as the number of samples where the taxon is present in the pollen sample but not in the associated vegetation plot and P1 as the number of samples where the taxon is only present in the vegetation plot. We calculated these indices separately for each sampling medium (Behling trap, modified Oldfield trap, Reference trap and soil sample) and each vegetation type (páramo, UMF, LMF, and PMF).

\subsection{Results}

\subsubsection{Pollen diagrams}

The percentage pollen diagram of the most abundant taxa is shown in Fig. 3. The different vegetation types of páramo, UMF, LMF and PMF are each dominated by characteristic pollen assemblage composition and palynological abundance. In the páramo, herb taxa characterise the vegetation. Herb taxa frequently found in the pollen rain of all traps as well as in the soil samples are Poaceae (10-70\%), Arcytophyllum type, Valeriana, Huperzia, Baccharis type and Cyperaceae. Furthermore, shrubs that occur in the local vegetation are recorded in the pollen rain. These 


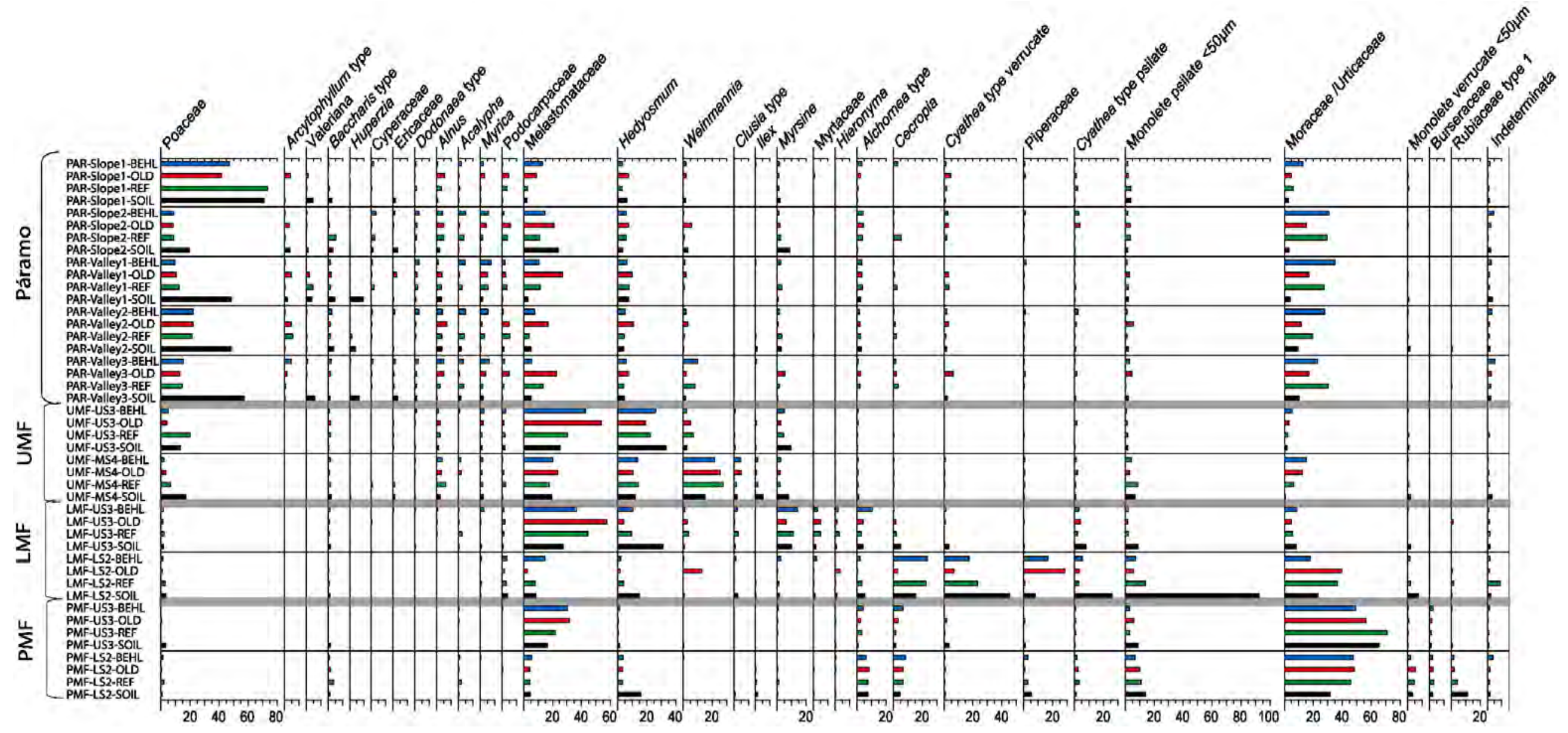

Figure 3. Pollen percentage diagram for the most important pollen and spore taxa from the different vegetation types. PAR- páramo, UMF - upper montane forest, LMF - lower montane forest, PMF premontane forest, BEHL - Behling trap, OLD - modified Oldfield trap, REF - Reference trap, SOIL- Soil sample. 
(a)

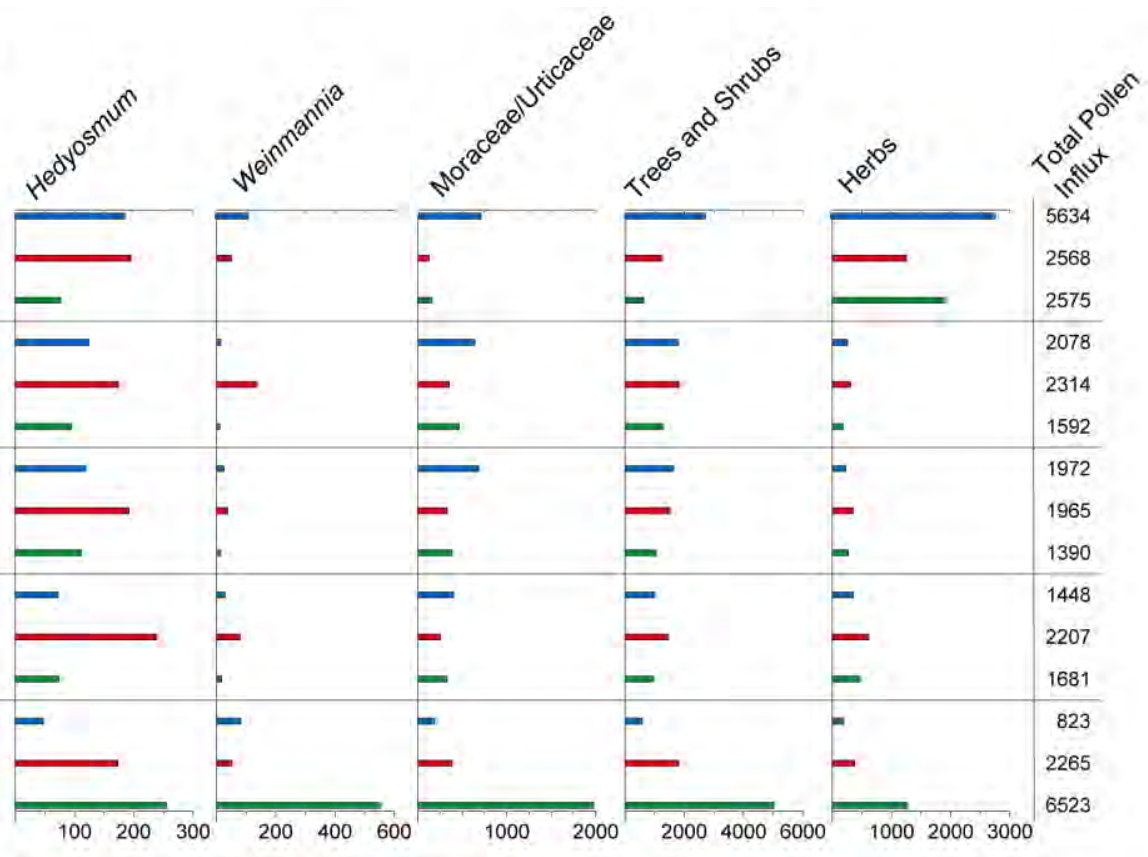

Pollen accumulation rates [grains/ $\mathrm{cm}^{2} /$ year]

(b)

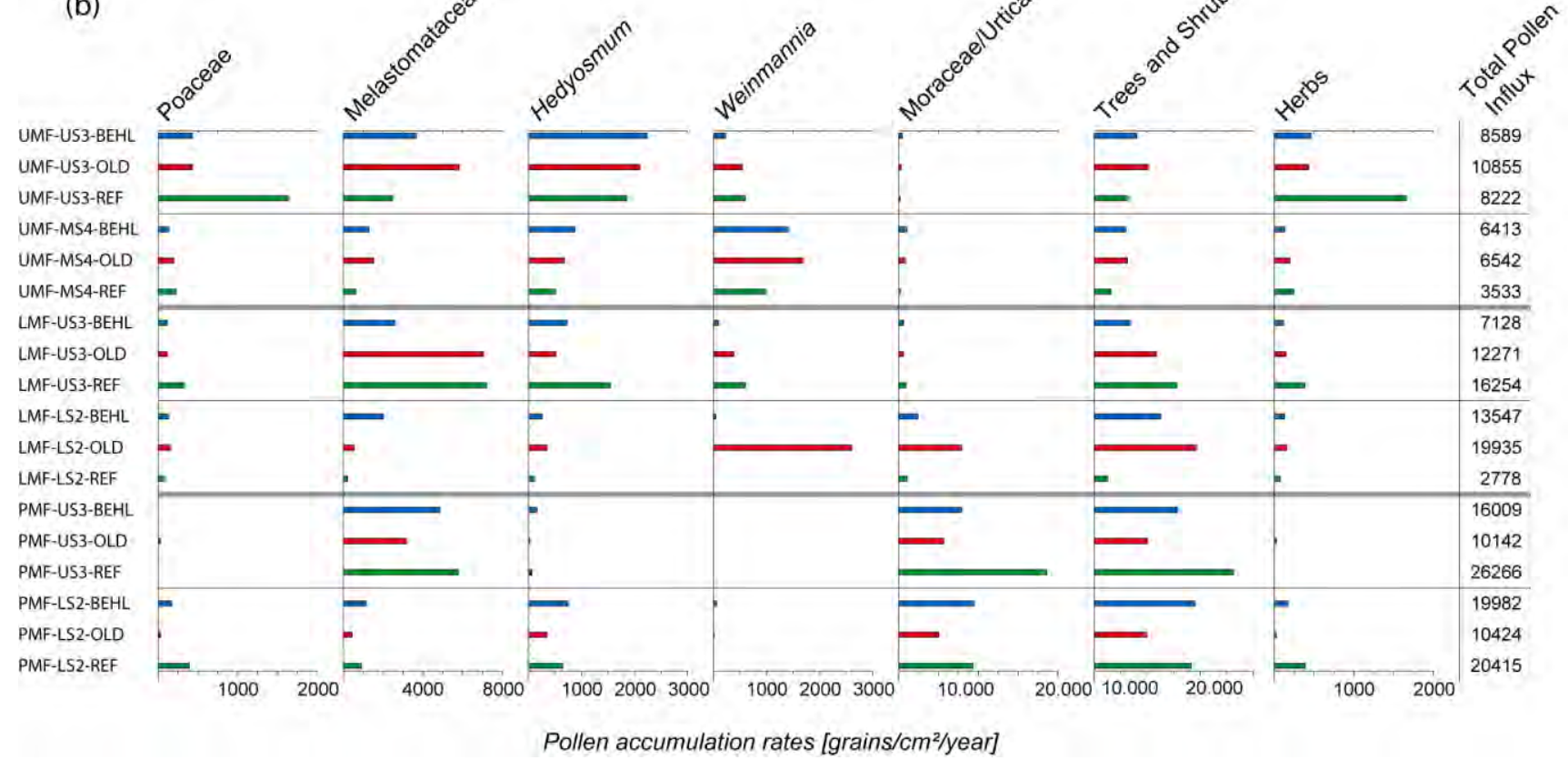

Figure 4. Pollen accumulation rates for the 5 most important pollen taxa across all of the studied vegetation types of (a) Páramo and (b) UMF, LMF and PMF. PAR- páramo, UMF - upper montane forest, LMF - lower montane forest, PMF - premontane forest, BEHL - Behling trap, OLD - modified Oldfield trap, REF - reference trap, SOIL- soil sample. Note the different scales. 
include Acalypha, Myrica, Melastomataceae, Weinmannia, and Myrsine. However, other taxa, which do not occur as plant in the páramo but in adjacent vegetation zones contribute to a great extent to the total pollen rain of the páramo samples, such as Moraceae/Urticaceae (up to $40 \%$ ), Hedyosmum, Alnus and Podocarpaceae. In general, all pollen trapping media show the same tendencies regarding species composition and percentage values of important pollen taxa. However, some marked differences are visible especially when comparing the soil samples to the pollen trap samples. In the pollen spectra of the soil samples, Poaceae show almost exceptionally higher percentage values than in the corresponding trap samples, whereas values of Moraceae/Urticaceae are lower in the former. For all other taxa, this is not the case. In the pollen spectra of the modified Oldfield traps, Moraceae/Urticaceae also show slightly lower values, but instead of Poaceae Melastomataceae are increased in their percentages. The pollen accumulation rates of the pollen rain for pollen traps of the páramo (Fig. 4) are generally much lower than those of the traps which were distributed in forested vegetation. Maximum values reach ca. 6500 grains $\mathrm{cm}^{-2}$ year ${ }^{-1}$, but 12 of the 15 traps distributed collected between 1000 and 3000 grains $\mathrm{cm}^{-2}$ year $^{-1}$. Most of the grains derive from trees and shrubs, whereas herbs only contribute comparatively little to the pollen accumulation rate in the páramo. Concerning the most important taxa, values of the different trap types do not vary significantly, however some marked differences are visible when looking at the values of important taxa, such as Melastomataceae, Hedyosmum and Moraceae/Urticaceae. The Behling traps show higher pollen accumulation rates than the other two trap types for Moraceae/Urticaceae, whereas the modified Oldfield traps often show the highest pollen accumulation rates in general.

Characteristic taxa for the modern pollen rain of the UMF are forest taxa which are common in the local vegetation, such as Melastomataceae, Hedyosmum, Weinmannia, Clusia type, Podocarpaceae, Myrica, Ilex, and Myrsine. However, also here, non-arboreal taxa and taxa that do not occur in the local vegetation are found in the pollen spectra. These include Poaceae, Alnus, and Moraceae/Urticaceae. Soil samples show the same deviations as in the páramo with lower percentages of Moraceae/Urticaceae but higher percentages of Poaceae than were recorded in the corresponding pollen traps. Pollen accumulation rates are considerably higher in the UMF

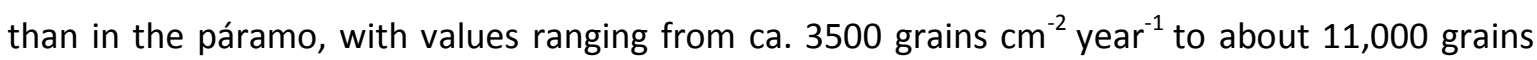
$\mathrm{cm}^{-2}$ year ${ }^{-1}$. The pollen accumulation rates of the most important taxa do not vary to a great extent (maximum variation found about 3300 grains $\mathrm{cm}^{-2} \mathrm{yr}^{-1}$ for Melastomataceae, compared to changes of up to 4500 grains $\mathrm{cm}^{-2} \mathrm{yr}^{-1}$ for the same taxon in the LMF) in the different trap types. However, as can be seen for the pollen accumulation rate of Poaceae in the reference trap of UMF US 3 , single taxa sometimes bias the data. 
In the LMF, pollen spectra mainly consist of tree taxa such as Melastomataceae, Moraceae/Urticaceae, Hedyosmum, Myrsine, Myrtaceae, Podocarpaceae, Hieronyma, Alchornea type, Cecropia, and Piperaceae. Fern spores of different species of Cyathea, as well as various taxa of monolete psilate spores reach highest values in this vegetation zone. Unlike in samples of the páramo or the UMF, pollen composition changes greatly from one sample to the next. However, within one site, all pollen sampling media record approximately the same pollen spectrum. The soil sample of LMF LS 2 is greatly biased towards a greater abundance of fern spores. The total pollen accumulation rates of the pollen traps from the LMF vary between ca. 3000 and ca. 20,000 grains $\mathrm{cm}^{-2}$ year ${ }^{-1}$. Here, values of particular taxa are greatly increased in single samples (e.g. Weinmannia in the modified Oldfield trap of LMF LS 2). However, the general tendency seems to be the same for most of the taxa and traps.

The pollen spectra of the PMF samples are represented by few taxa which reach high percentages, such as Moraceae/Urticaceae with values of up to $70 \%$ and Melastomataceae (up to ca. 30\%), and taxa with lower values, such as Hedyosmum, Alchornea type, Cecropia, Piperaceae, Rubiaceae type 1, Burseraceae, and different fern spores, such as Cyathea spore morphotypes verrucate and psilate, as well as by monolete psilate and verrucate fern spores $<50 \mu \mathrm{m}$. Percentage values of different sampling media remain rather consistent within one plot. Pollen accumulation rates vary between ca. 10,000 and ca. 26,000 grains $\mathrm{cm}^{-2}$ year $^{-1}$ for samples of the PMF, mostly due to a very high pollen accumulation rate of Moraceae/Urticaceae, which reach values of between 5000 and 20,000 grains $\mathrm{cm}^{-2}$ year ${ }^{-1}$. The pollen accumulation rates of herbs are low in this vegetation type, with maximum values below 500 grains $\mathrm{cm}^{-2}$ year $^{-1}$. As in the different traps of the LMF, also here pollen accumulation rates of some taxa are increased in single traps, as for example Moraceae/Urticaceae in the reference trap of PMF-US 3.

\subsubsection{Multivariate data analyses}

The PCAs of the different sampling media for every vegetation type are shown in Fig. 5. For the samples of the páramo, differences in the pollen spectra of the sampling media account for most of the gradient. Most modified Oldfield traps are located close to one another and correlate with higher values of Melastomataceae. The Behling traps and the reference samples correlate to a similar extent to one another and to Moraceae/Urticaceae, Acalypha, Myrica and Dodonaea type. The soil samples in general, as well as the samples of Slope 1, correlate positively with the abundance of Poaceae.

The analyses of taxa from the forested vegetation zones show a different pattern. Here, the location of the sample is more important, and the $x$-axis accounts for the gradient which is 

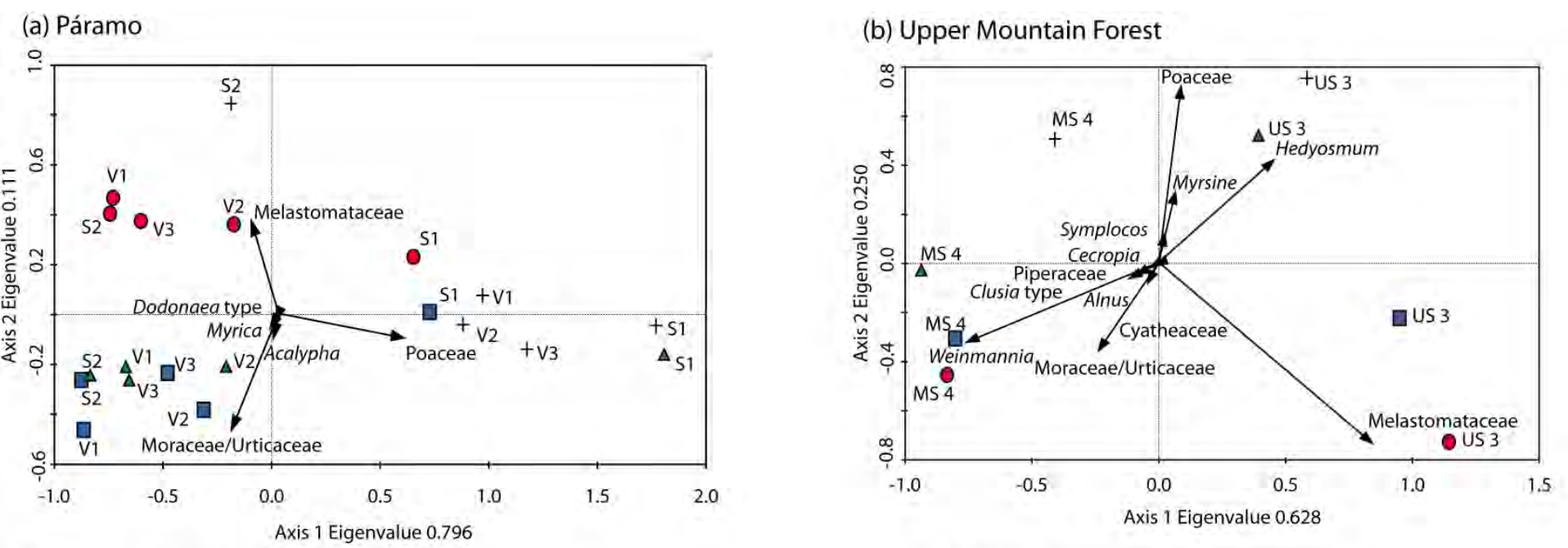

(c) Lower Mountain Forest
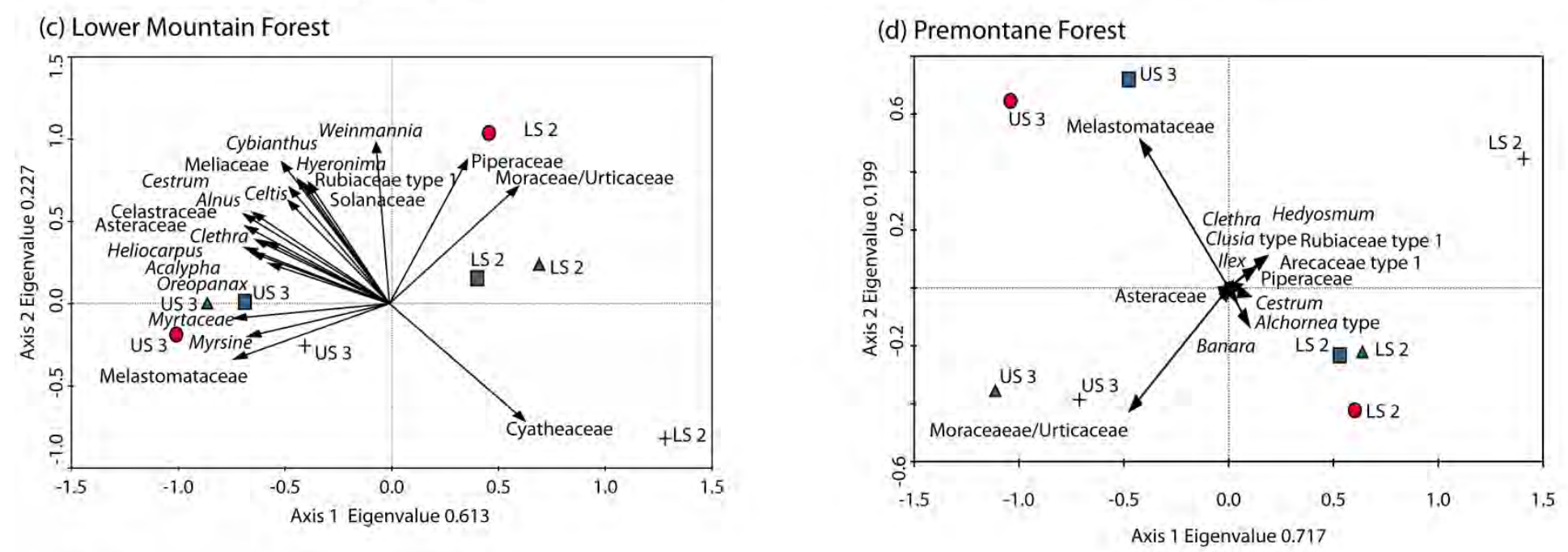

SPECIES

$\rightarrow$

SAMPLES

$\square$ Behling Traps

- Modified Oldfield Traps

$\Delta$ ReferenceTraps + Soil Samples

Figure 5. PCAs of pollen and plant data for the different vegetation types. (a) Páramo; (b) upper montane forest; (c) lower montane forest; (d) premontane forest. S - Slope, V Valley, LS - Lower slope, MS - Mid-slope, US - Upper slope. 
Table 2 a-d. Association and representation indices after Davis (1984) for important pollen taxa that are abundant in either pollen rain or vegetation for the different vegetation types: (a) premontane forest; (b) lower montane forest; (c) upper montane forest; (d) páramo. Data for premontane, lower montane and upper montane forest are based on two traps of each type, whereas for the páramo, we used five traps of each type for the calculations. $A=A s s o c i a t i o n, U=$ under-representation and $\mathrm{O}=$ over-representation, $\mathrm{Behl}=$ Behling trap, Old $=$ modified Oldfield trap, Ref $=$ reference trap, Soil = Soil sample. Values over 0.5 are shaded in light grey, values over 0.7 are shaded in dark grey.

(a) Premontane forest

A

U

0

\begin{tabular}{lllll|llll|llll} 
& Behl & Old & Ref & Soil & Behl & Old & Ref & Soil & Behl & Old & Ref & Soil \\
\hline Arecaceae & 1.0 & 1.0 & 1.0 & 1.0 & 0.0 & 0.0 & 0.0 & 0.0 & 0.0 & 0.0 & 0.0 & 0.0 \\
Burseraceae & 1.0 & 1.0 & 1.0 & 1.0 & 0.0 & 0.0 & 0.0 & 0.0 & 0.0 & 0.0 & 0.0 & 0.0 \\
Hieronyma & 1.0 & 0.5 & 0.0 & 0.5 & 0.0 & 0.0 & 1.0 & 0.0 & 0.0 & 0.5 & 0.0 & 0.5 \\
Lauraceae & 1.0 & 1.0 & 0.0 & 0.0 & 0.0 & 0.0 & 1.0 & 1.0 & 0.0 & 0.0 & 0.0 & 0.0 \\
Melastomataceae & 1.0 & 1.0 & 1.0 & 1.0 & 0.0 & 0.0 & 0.0 & 0.0 & 0.0 & 0.0 & 0.0 & 0.0 \\
Moraceae/Urticaceae & 1.0 & 1.0 & 1.0 & 1.0 & 0.0 & 0.0 & 0.0 & 0.0 & 0.0 & 0.0 & 0.0 & 0.0 \\
Licania & 0.0 & 0.0 & 0.0 & 0.0 & 1.0 & 1.0 & 1.0 & 1.0 & 0.0 & 0.0 & 0.0 & 0.0 \\
Sapotaceae & 0.0 & 1.0 & 0.0 & 0.0 & 1.0 & 0.0 & 1.0 & 1.0 & 0.0 & 0.0 & 0.0 & 0.0 \\
Hedyosmum & 0.5 & 0.5 & 0.5 & 0.5 & 0.0 & 0.0 & 0.0 & 0.0 & 0.5 & 0.5 & 0.5 & 0.5 \\
Alchornea type & 0.3 & 0.3 & 0.3 & 0.3 & 0.0 & 0.0 & 0.0 & 0.0 & 0.7 & 0.7 & 0.7 & 0.7 \\
Asteraceae & 0.3 & 0.3 & 0.0 & 0.3 & 0.0 & 0.0 & 0.0 & 0.0 & 0.7 & 0.7 & 1.0 & 0.7 \\
Ilex & 0.0 & 0.0 & 0.0 & 0.0 & 0.0 & 0.0 & 0.0 & 0.0 & 0.0 & 1.0 & 1.0 & 1.0 \\
Poaceae & 0.0 & 0.3 & 0.0 & 0.3 & 0.0 & 0.0 & 0.0 & 0.0 & 1.0 & 0.7 & 1.0 & 0.7
\end{tabular}

(b) Lower montane

\begin{tabular}{lrccc|cccc|cccc} 
forest & \multicolumn{1}{c}{ A } & \multicolumn{4}{c}{ U } & \multicolumn{4}{c}{ O } \\
& Behl & Old & Ref & Soil & Behl & Old & Ref & Soil & Behl & Old & Ref & Soil \\
\hline Alchornea type & 1.0 & 1.0 & 1.0 & 1.0 & 0.0 & 0.0 & 0.0 & 0.0 & 0.0 & 0.0 & 0.0 & 0.0 \\
Moraceae/Urticaceae & 1.0 & 1.0 & 1.0 & 1.0 & 0.0 & 0.0 & 0.0 & 0.0 & 0.0 & 0.0 & 0.0 & 0.0 \\
Hieronyma & 1.0 & 0.5 & 0.5 & 0.5 & 0.0 & 0.0 & 0.0 & 0.0 & 0.0 & 0.5 & 0.5 & 0.5 \\
Lauraceae & 1.0 & 0.5 & 1.0 & 0.0 & 0.0 & 0.5 & 0.0 & 0.0 & 0.0 & 0.0 & 0.0 & 1.0 \\
Piperaceae & 1.0 & 0.5 & 1.0 & 0.5 & 0.0 & 0.0 & 0.0 & 0.0 & 0.0 & 0.5 & 0.0 & 0.5 \\
Weinmannia & 0.5 & 0.5 & 1.0 & 0.5 & 0.0 & 0.0 & 0.0 & 0.0 & 0.5 & 0.5 & 0.0 & 0.5 \\
Alzatea & 0.0 & 0.0 & 0.0 & 0.0 & 1.0 & 1.0 & 1.0 & 1.0 & 0.0 & 0.0 & 0.0 & 0.0 \\
Annonaceae & 0.0 & 0.0 & 0.0 & 0.0 & 1.0 & 1.0 & 1.0 & 1.0 & 0.0 & 0.0 & 0.0 & 0.0 \\
Gordonia & 0.0 & 0.0 & 0.0 & 0.0 & 1.0 & 1.0 & 1.0 & 1.0 & 0.0 & 0.0 & 0.0 & 0.0 \\
Tabebuia & 0.0 & 0.0 & 0.0 & 0.0 & 1.0 & 1.0 & 1.0 & 1.0 & 0.0 & 0.0 & 0.0 & 0.0 \\
Acalypha & 0.3 & 0.0 & 0.0 & 0.0 & 0.0 & 0.0 & 0.0 & 0.0 & 1.0 & 1.0 & 1.0 & 0.7 \\
Alnus & 0.0 & 0.0 & 0.0 & 0.0 & 0.0 & 0.0 & 0.0 & 0.0 & 1.0 & 1.0 & 1.0 & 0.0 \\
Myrica & 0.3 & 0.3 & 0.0 & 0.3 & 0.0 & 0.0 & 0.0 & 0.0 & 0.7 & 0.7 & 1.0 & 0.7 \\
Myrsine & 0.3 & 0.3 & 0.3 & 0.3 & 0.0 & 0.0 & 0.0 & 0.0 & 0.7 & 0.7 & 0.7 & 0.7 \\
Melastomataceae & 0.5 & 0.5 & 0.5 & 0.5 & 0.0 & 0.0 & 0.0 & 0.0 & 0.5 & 0.5 & 0.5 & 0.5 \\
Myrtaceae & 0.5 & 0.5 & 0.5 & 0.5 & 0.0 & 0.0 & 0.0 & 0.0 & 0.5 & 0.5 & 0.5 & 0.5 \\
Hedyosmum & 0.5 & 0.5 & 0.5 & 0.5 & 0.0 & 0.0 & 0.0 & 0.0 & 0.5 & 0.5 & 0.5 & 0.5
\end{tabular}


(c) Upper montane

\begin{tabular}{lrrrr|rrrr|rrrr} 
forest & \multicolumn{9}{c}{ A } & \multicolumn{1}{c}{ U } \\
& Behl & Old & Ref & Soil & Behl & Old & Ref & Soil & Behl & Old & Ref & Soil \\
\hline Melastomataceae & 1.0 & 1.0 & 1.0 & 1.0 & 0.0 & 0.0 & 0.0 & 0.0 & 0.0 & 0.0 & 0.0 & 0.0 \\
Myrsine & 1.0 & 1.0 & 1.0 & 1.0 & 0.0 & 0.0 & 0.0 & 0.0 & 0.0 & 0.0 & 0.0 & 0.0 \\
Oreopanax & 1.0 & 1.0 & 0.5 & 1.0 & 0.0 & 0.0 & 0.0 & 0.0 & 0.0 & 0.0 & 0.5 & 0.0 \\
Podocarpaceae & 1.0 & 1.0 & 1.0 & 1.0 & 0.0 & 0.0 & 0.0 & 0.0 & 0.0 & 0.0 & 0.0 & 0.0 \\
Weinmannia & 1.0 & 1.0 & 1.0 & 1.0 & 0.0 & 0.0 & 0.0 & 0.0 & 0.0 & 0.0 & 0.0 & 0.0 \\
Ilex & 0.5 & 1.0 & 0.5 & 1.0 & 0.5 & 0.0 & 0.5 & 0.0 & 0.0 & 0.0 & 0.0 & 0.0 \\
Lauraceae & 0.3 & 1.0 & 0.5 & 0.3 & 0.7 & 0.0 & 0.5 & 0.7 & 0.0 & 0.0 & 0.0 & 0.0 \\
Celastraceae & 0.5 & 0.0 & 0.0 & 1.0 & 0.0 & 1.0 & 1.0 & 0.0 & 0.5 & 0.0 & 0.0 & 0.0 \\
Symplocos & 0.3 & 0.3 & 0.5 & 1.0 & 0.7 & 0.7 & 0.5 & 0.0 & 0.0 & 0.0 & 0.0 & 0.0 \\
Hedyosmum & 0.5 & 0.5 & 0.5 & 0.5 & 0.0 & 0.0 & 0.0 & 0.0 & 0.5 & 0.5 & 0.5 & 0.5 \\
Clusia type & 0.5 & 0.5 & 0.5 & 0.5 & 0.0 & 0.0 & 0.0 & 0.0 & 0.5 & 0.5 & 0.5 & 0.5 \\
Acalypha & 0.3 & 0.0 & 0.0 & 0.0 & 0.0 & 0.0 & 0.0 & 0.0 & 0.7 & 1.0 & 0.0 & 0.0 \\
Clethra & 0.3 & 0.0 & 0.3 & 0.3 & 0.0 & 0.0 & 0.0 & 0.0 & 0.7 & 1.0 & 0.7 & 0.7 \\
Cecropia & 0.0 & 0.0 & 0.3 & 0.0 & 0.0 & 0.0 & 0.0 & 0.0 & 1.0 & 1.0 & 0.7 & 0.0 \\
Cybianthus & 0.0 & 0.0 & 0.0 & 0.3 & 0.0 & 0.0 & 0.0 & 0.0 & 0.0 & 1.0 & 1.0 & 0.7 \\
Piperaceae & 0.0 & 0.0 & 0.3 & 0.0 & 0.0 & 0.0 & 0.0 & 0.0 & 1.0 & 1.0 & 0.7 & 1.0
\end{tabular}

(d) Páramo

A

U

0

\begin{tabular}{lll|llll|llll} 
Behl Old Ref & Soil & Behl Old Ref & Soil & Behl Old Ref Soil
\end{tabular}

\begin{tabular}{lllll|llll|llll}
\hline Asteraceae & 1.0 & 1.0 & 1.0 & 1.0 & 0.0 & 0.0 & 0.0 & 0.0 & 0.0 & 0.0 & 0.0 & 0.0 \\
Poaceae & 1.0 & 1.0 & 1.0 & 1.0 & 0.0 & 0.0 & 0.0 & 0.0 & 0.0 & 0.0 & 0.0 & 0.0 \\
Melastomataceae & 0.7 & 0.8 & 0.8 & 0.8 & 0.0 & 0.0 & 0.0 & 0.0 & 0.3 & 0.2 & 0.2 & 0.2 \\
Cyperaceae & 0.8 & 0.8 & 0.8 & 0.3 & 0.0 & 0.0 & 0.0 & 0.8 & 0.2 & 0.2 & 0.2 & 0.0 \\
Valeriana & 0.2 & 0.8 & 0.5 & 0.6 & 0.7 & 0.0 & 0.3 & 0.0 & 0.7 & 0.3 & 0.3 & 0.4 \\
Ericaceae & 0.6 & 0.6 & 0.2 & 1.0 & 0.4 & 0.4 & 0.8 & 0.0 & 0.0 & 0.0 & 0.0 & 0.0 \\
Arcytophyllum type & 0.4 & 0.6 & 0.4 & 0.6 & 0.3 & 0.0 & 0.3 & 0.0 & 0.5 & 0.4 & 0.5 & 0.4 \\
Eriocaulaceae & 0.0 & 0.0 & 0.0 & 0.0 & 1.0 & 1.0 & 1.0 & 1.0 & 0.0 & 0.0 & 0.0 & 0.0 \\
Xyris & 0.0 & 0.0 & 0.0 & 0.0 & 1.0 & 1.0 & 1.0 & 1.0 & 0.0 & 0.0 & 0.0 & 0.0 \\
Hypericum & 0.3 & 0.0 & 0.0 & 0.5 & 0.7 & 1.0 & 1.0 & 0.3 & 0.0 & 1.0 & 1.0 & 0.3 \\
Acalypha & 0.0 & 0.0 & 0.0 & 0.0 & 0.0 & 0.0 & 0.0 & 0.0 & 1.0 & 1.0 & 1.0 & 1.0 \\
Alchornea type & 0.0 & 0.0 & 0.0 & 0.0 & 0.0 & 0.0 & 0.0 & 0.0 & 1.0 & 1.0 & 1.0 & 1.0 \\
Myrsine & 0.3 & 0.3 & 0.3 & 0.0 & 0.0 & 0.0 & 0.0 & 0.0 & 0.8 & 0.8 & 0.7 & 1.0 \\
Alnus & 0.0 & 0.0 & 0.0 & 0.0 & 0.0 & 0.0 & 0.0 & 0.0 & 1.0 & 1.0 & 1.0 & 1.0 \\
Cecropia & 0.0 & 0.0 & 0.0 & 0.0 & 0.0 & 0.0 & 0.0 & 0.0 & 1.0 & 1.0 & 1.0 & 0.0 \\
Celtis & 0.0 & 0.0 & 0.0 & 0.0 & 0.0 & 0.0 & 0.0 & 0.0 & 1.0 & 1.0 & 1.0 & 1.0 \\
Dodonaea type & 0.0 & 0.0 & 0.0 & 0.0 & 0.0 & 0.0 & 0.0 & 0.0 & 1.0 & 1.0 & 1.0 & 1.0 \\
Hedyosmum & 0.0 & 0.0 & 0.0 & 0.0 & 0.0 & 0.0 & 0.0 & 0.0 & 1.0 & 1.0 & 1.0 & 1.0 \\
Lauraceae & 0.0 & 0.0 & 0.0 & 0.0 & 0.0 & 0.0 & 0.0 & 0.0 & 1.0 & 1.0 & 1.0 & 0.0 \\
Moraceae/Urticaceae & 0.0 & 0.0 & 0.0 & 0.0 & 0.0 & 0.0 & 0.0 & 0.0 & 1.0 & 1.0 & 1.0 & 1.0 \\
Myrica & 0.0 & 0.0 & 0.0 & 0.0 & 0.0 & 0.0 & 0.0 & 0.0 & 1.0 & 1.0 & 1.0 & 1.0 \\
Podocarpaceae & 0.0 & 0.0 & 0.0 & 0.0 & 0.0 & 0.0 & 0.0 & 0.0 & 1.0 & 1.0 & 1.0 & 1.0 \\
Weinmannia & 0.0 & 0.0 & 0.0 & 0.0 & 0.0 & 0.0 & 0.0 & 0.0 & 1.0 & 1.0 & 1.0 & 1.0 \\
Theaceae & 0.0 & 0.0 & 0.0 & 0.0 & 0.0 & 0.0 & 0.0 & 0.0 & 1.0 & 1.0 & 0.0 & 1.0
\end{tabular}


created by the difference in pollen composition of the specific samples within one vegetation type.

For the UMF, samples from US 3 are separated from the ones of MS 4 . The former correlate well with Melastomataceae and Hedyosmum, whereas the latter correspond positively to the abundance of Piperaceae, Clusia type, Alnus, Cyatheaceae, Moraceae/Urticaceae and Weinmannia. Here, Behling trap samples and modified Oldfield trap samples correlate well with each other, whereas the distance of the former to the soil samples is bigger. These correlate well with Poaceae, Myrsine, and Symplocos.

The PCA of samples from the LMF shows that samples of US 3 correlate positively with the abundance of Melastomataceae, Myrsine, and Myrtaceae, whereas the ones of LS 2 show a higher correlation to Piperaceae and Moraceae/Urticaceae. The soil sample of this plot shows a positive response to the abundance of Cyatheaceae.

For the PMF, samples show a different pattern. The samples of US 3 spread over a large gradient on the $y$-axis, which is determined by the positive correlation of both the Behling and the modified Oldfield trap with Melastomataceae on the one side and the positive correlation to Moraceae/Urticaceae of the soil and the reference sample on the other side. For the samples of LS 2, the Behling trap as well as the reference trap and the modified Oldfield trap samples correlate positively to higher abundance of Cestrum, Alchornea type, and Banara, whereas the soil sample responds to a higher affinity to Hedyosmum, Arecaceae type 1, Rubiaceae type 1, and Piperaceae.

\subsubsection{Indices of association and representation and diversity}

The comparison of indices of association and representation per collection medium for the most important taxa of each vegetation zone are seen in Table2a-d.Only the most characteristic taxa with high scores that had values of at least $2 \%$ in the vegetation or pollen data are shown. Many times, the association indices of one taxon are the same for all sampling media. Generally, very few taxa are strongly associated taxa which can be found to an equal extent in the vegetation as well as in the modern pollen spectra. These are often taxa which are wind-pollinated and/or abundant in the vegetation of the specific vegetation type, as for example Melastomataceae for LMF, UMF and páramo, and Moraceae/Urticaceae for PMF and LMF. Under-represented taxa in the pollen spectra are often insect-pollinated and/or not frequent, such as Licania or Sapotaceae in the PMF samples, Annonaceae, Gordonia, Tabebuia or Alzatea in the LMF samples, Celastraceae or Symplocos in the UMF samples or Xyris and Hypericum in the páramo samples. The same is true for generally fragile and easily destroyable pollen grains such as the ones of Lauraceae. Very abundant taxa that are over-represented in the pollen rain are often light grains 
which belong to wind-pollinating species, such as Piperaceae, Cecropia, Moraceae/Urticaceae, Acalypha or Poaceae. Not all of the trapping media recorded the representation indices in the same way. This is especially conspicuous in the soil samples, which frequently show differences in comparison to the other traps. Some taxa are either especially under-represented or not overrepresented in the soil samples. These are Lauraceae in the PMF, Alnus in the LMF, Acalypha and Cecropia in the UMF, and Cyperaceae, Lauraceae as well as Cecropia in the páramo samples. The same is true for some taxa in the reference samples, such as Ericaceae in the páramo, Acalypha and Celastraceae in the UMF, and Hieronyma in the PMF. For the Behling and modified Oldfield traps, similar patterns of under-representation can be observed, but mostly with taxa that are not very abundant in the corresponding pollen spectrum and/or vegetation type.

The results of the individual-based rarefaction ( $\mathrm{N}=280$ counted pollen grains) of mean values for every type of vegetation and sampling medium with their standard deviation can be seen in Fig.6. The values do not differ to one another to a significant extent. However, for the páramo, the Behling traps and the modified Oldfield traps show higher pollen type richness than the reference traps and the soil samples whereas generally, soil samples tend to have the highest diversity.

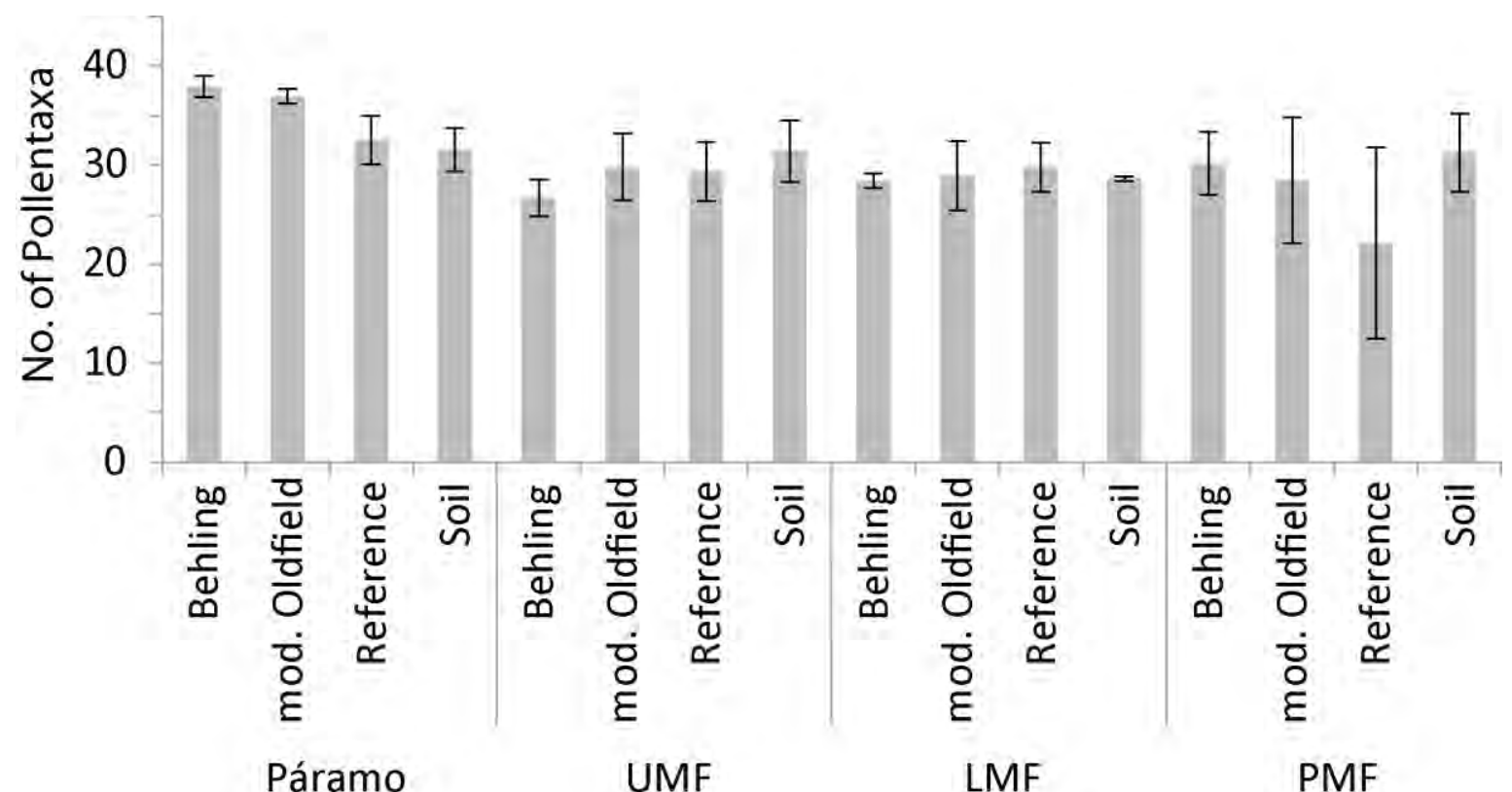

Figure 6. Individual-based rarefaction data (Krebs, 1989) for the medium pollen and spore taxa diversity of each vegetation type and for each trapping medium. The calculation is based on $\mathrm{N}=\mathbf{2 8 0}$ counted pollen and spore grains. The error bars are standard deviations. 


\subsection{Discussion}

The different sampling media, Behling traps, modified Oldfield traps, reference traps and soil samples, all recorded similar patterns in the modern pollen rain spectra of the different vegetation types of páramo, UMF, LMF, and PMF. However, some marked differences between the results of the sampling media which were revealed by different analyses are discussed below.

To what extent do different pollen trap types and soil samples collect pollen rain in a different way and how is it reflected in the data?

All sampling media roughly represent the same pollen composition for each of the sites. However, abundances sometimes vary between the sampling media. The most striking differences can be seen between the pollen traps and the soil samples. This is due to several factors which determine pollen abundance in a sample. The first reason is that soil samples collect pollen for an unknown amount of time. Unlike in all of the traps, where pollen rain has been collected for exactly one year and thus all data refer to this year, soil samples collect pollen for several to many years, depending on the sedimentation rate. Unfortunately, the exact time a soil sample covers cannot be determined with certainty. Therefore, a soil sample may not only capture the pollen composition and abundance of the given vegetation at the time the sample was collected, but may also contain information about past vegetation and its changes. This can have an effect in areas with bigger human influence, such as deforestation, logging of single tree taxa or burning. However, to our knowledge, this is not the case in our study region. On the other hand, soil samples, in comparison to pollen traps, do neither record annual production peaks nor periods of low pollen production which hinder an average overview of the pollen spectrum of an area or vegetation type, as it can be the case when collecting too few years of modern pollen rain in pollen traps (Hicks et al., 2001). The second reason for the different pollen composition and abundance in soil samples is the fact that fragile grains with a thin exine can get destroyed in soils due to mechanical or chemical corrosion (Wilmshurst and McGlone, 2005), and are thus not recorded anymore. Therefore, taxa such as Moraceae/Urticaceae, Acalypha, Cyperaceae, Cecropia and Lauraceae are always under-represented or less over-represented in the soil samples, whereas grains with a thick and stable exine, such as Cyatheaceae, Hedyosmum and some Poaceae are generally recorded with a higher abundance than in other sampling media, as seen by the representation indices, as well as in the pollen diagrams and the PCAs.

The sampling device which shows the most similar pollen composition to the soil samples is the reference trap. Often, the reference samples record similar proportions of important taxa as the soil samples and also here, some taxa are less over-represented or sometimes under-represented, 
as Ericaceae in the páramo, Acalypha and Celastraceae in the UMF, and Hieronyma in the PMF. As the reference sample has no trapping medium such as synthetic cotton or a filter, pollen is simply collected in a bottle of water and can thus easily flow out during heavy rainfalls. This may especially affect pollen grains with a low fall speed, such as Moraceae/Urticaceae (with a fall velocity of c. $0.34-0.4 \mathrm{~cm} / \mathrm{s}$, cited after Holmes, 1994), which do not sink easily. Surprisingly, some of the reference traps still have the same or even higher pollen accumulation rates than the other traps. However, the reference samples collect pollen in a more random way, which can be seen by their position in the PCAs and by their percentages, which often lie between the soil samples and the other pollen trap types. Also, especially in the páramo, soil samples and reference traps have a lower number of recorded pollen taxa per 280 counted pollen grains than Behling and modified Oldfield traps. This may be explained by the formally mentioned fact of random pollen collection which results from a lack of specific trapping devices in these sampling media. Interestingly, soil samples show highest diversity values in the analysed forest types. This is, because Moraceae/Urticaceae, which dominate the modern pollen spectra of the traps especially in LMF and PMF are less over-represented in soil samples, which thus have an increased probability for the detection of rare taxa.

\section{Which pollen trap is most suitable for which tropical vegetation?}

The modified Oldfield and Behling traps are mostly closely related to one another when regarding pollen taxonomic composition and their proportions, as well as association and representation indices. However, in the páramo, this does not seem to be the case, as here, the pollen composition of the Behling traps is more similar to the reference traps, which is especially due to their positive correlation to Moraceae/Urticaceae, Acalypha, Myrica, and Dodonaea type. A possible reason which may explain this observation is the fact that in the páramo, environmental conditions to which the pollen traps are exposed are different than in the forested regions of tropical mountains. In both regions humidity is very high. Therefore, the Oldfield trap, which can handle very wet environmental conditions, is commonly used in tropical moist regions. Bush (1992) modified the Oldfield trap design so that a bottle with a drainage system was used instead of a conical flask. However, even though humidity in tropical regions may be very high during rainy periods, radiation increases with altitude (Bendix et al., 2008) and dry periods can occur. As Gosling et al. (2003) reported, a bottle which is attached to the Oldfield trap does not prevent the trap from drying out, so that using a simple stake would lead to the same results. This could be seen in our study as well. When the traps were recollected, many of them showed signs of disintegration and all of the modified Oldfield traps were dried out completely and the filter and cotton could only be recollected in pieces. This may explain why in these traps, the abundance of 
fragile grains such as Moraceae/Urticaceae and Acalypha is lower than in the Behling or reference traps, which can hold more water. However, pollen accumulation rates do not seem to have decreased greatly in the modified Oldfield traps of the páramo and the diversity is also almost as high as in the Behling traps. Higher pollen accumulation rates in the modified Oldfield traps may be caused also by the larger trap opening, which could lead to higher wind turbulences within the trap and thus to more pollen influx. However, this assumption has to be proven by further studies. Another point that may have affected the different pollen spectra and proportions especially in the modified Oldfield traps of the páramo is the fact that they generally trapped pollen from at least $20 \mathrm{~cm}$ above ground, whereas the Behling traps was installed at about $12 \mathrm{~cm}$ above ground and the reference trap at almost ground level. The same is true for the traps in the forest, but here, the effect on pollen composition may not be as strong, as almost all pollen grains are transported from the canopy-layer downwards to the pollen traps. In open, low vegetation, the traps stick out of the vegetation and the pollen grains have to be transported at least slightly upwards to be caught in the traps. This is especially true for the modified Oldfield traps. Possibly, other wind patterns carrying other pollen grains from a larger distance affect those pollen traps. However, yet further research has to be done to determine the distribution properties, vertical pollen distribution and prevailing wind patterns in different neotropical ecosystems. Nevertheless, for the reasons mentioned above, we recommend the use of Behling traps for the páramo and other types of tropical open and/or dry vegetation, whereas for forest vegetation, all trap types seem to provide equally good results.

\subsection{Conclusions}

1. All studied four vegetation types, páramo, UMF, LMF and PMF, show distinct pollen spectra of modern pollen rain which reflect local to regional vegetation conditions.

2. All of the trap types as well as the soil samples are useful pollen and spore sampling media which in general produce similar modern pollen rain spectra.

3. In the soil samples, taxa with a fragile exine, such as Moraceae/Urticaceae, Acalypha, Cyperaceae, Cecropia and Lauraceae are represented to a lesser extent (i.e. more often under-represented or less over-represented) than in the pollen traps, whereas Poaceae have a higher representation than in the traps.

4. For the collection of pollen rain from open vegetation, Behling traps are a better choice than modified Oldfield traps, as they collect pollen closer to the ground and do not dry out as easily. Thus, with Behling traps, pollen grains are less corroded and the pollen spectra and their pollen accumulation rates are more similar to the ones that arrive on the soil surface. 
5. Generally, more effort should be attempted to develop pollen traps that withstand the difficult collection circumstances of tropical environments and to establish long-term pollen rain monitoring sites for different tropical ecosystems.

\subsection{Acknowledgements}

We thank Andrea and Stephany Villota, Nixon Cumbicus, and Jaime Peña for the assistance in the field. The local managers of the FOR 816 are thanked for logistical support. We are grateful for receiving research grants by the DFG project FOR 816 (Grants BE2116/8-2 and HO3296/2-2). Our thanks also go to two anonymous reviewers, who gave useful comments and suggestions that helped to improve the paper.

\section{8 References}

APG (=The Angiosperm Phylogeny Group) III, 2009. An update of the Angiosperm Phylogeny Group classification for the orders and families of flowering plants: APG III. Botenical Journal of the Linnean Society 161, 105-121.

Beck, E., F. Makeschin, F. Haubrich, M. Richter, J. Bendix, and C. Valerezo. 2008. The ecosystem (Reserva Biológica San Francisco). Pages 1-13 in: Beck, E., J. Bendix, I. Kottke, F. Makeschin, and R. Mosandl, editors. Gradients in a tropical mountain ecosystem of Ecuador. Springer, Berlin.

Behling, H., M. Cohen, and R. Lara, 2001. Studies on Holocene mangrove ecosystem dynamics of the Bragança Peninsula in north-eastern Pará, Brazil. Palaeogeography, Palaeoclimatolology, Palaeoecololgy 167, 225-242.

Bendix, J., J. Homeier, E. Cueva Ortiz, P. Emck, S.-W. Breckle, M. Richter, and E. Beck. 2006. Seasonality of weather and tree phenology in a tropical evergreen mountain rain forest. International Journal of Biometeorology 50, 370-384.

Bendix, J., R. Rollenbeck, M. Richter,P. Fabian, and P. Emck. 2008. Climate. Pages 63-73 in: Beck, E., J. Bendix, I. Kottke, F. Makeschin, and R. Mosandl, editors, Gradients in a Tropical Mountain Ecosystem of Ecuador. Springer, Berlin.

Brunschön, C., and H. Behling. 2009. Late Quaternary vegetation, fire and climate history reconstructed from two cores at Cerro Toledo, Podocarpus National Park, southeastern Ecuadorian Andes. Quaternary Research 72, 388-399.

Burn, M., F. Mayle, and T. Killeen. 2010. Pollen-based differentiation of Amazonian rainforest communities and implications for lowland paleoecology in tropical South America. Palaeogeography Palaeoclimatology, Palaeoecology 295, 1-18.

Bush, M. 1992. A simple yet efficient pollen trap for use in vegetation studies. Journal of Vegetation Science 3, 275-276.

Bush, M. 2000. Deriving Response Matrices from Central American Modern Pollen Rain. Quaternary Research 54, 132-143.

Bush, M., E. Moreno, P. De Oliveira, E. Asanza, and P. Colinvaux. 2001. The influence of biogeographic and ecological heterogeneity on Amazonian pollen spectra. Journal of Tropical Ecology 17, 729-743.

Bush, M., and R. Rivera. 1998. Pollen dispersal and representation in a neotropical rain forest. Global Ecology and Biogeography 7, 379-392.

Bush, M., and R. Rivera. 2001. Reproductive ecology and pollen representation among neotropical trees. Global Ecology and Biogeography 10, 359-367.

Bush, M., and C. Weng. 2007. Introducing a new (freeware) tool for palynology. Journal of Biogeography 34, 377-380. 
Colinvaux, P., and P. De Oliveira. 1999. Amazon pollen manual and atlas = Manual e atlas palinologico da Amazonia. Harwood Academic Publishers. Amsterdam.

Collins, A., and M. Bush. 2010. An analysis of modern pollen representation and climatic conditions on the Galapagos Islands. The Holocene 21, 237-250.

Cundill, P., 1991. Comparisons of moss polster and pollen trap data: a pilot study. Grana 30, 301308.

Davis, O., 1984. Pollen frequencies reflect vegetation patterns in a great basin (U.S.A.) mountain range. Review of Palaeobotany and Palynology 40, 295-315.

Emck, P., 2007. A climatology of South Ecuador - With special focus on the Major Andean Ridge as Atlantic-Pacific Climate Divide. PhD thesis. University Erlangen-Nürnberg.

European Pollen Monitoring Programme.URL http://www.pollentrapping.net, Accessed 20 June, 2012.

Fall, P., 1992. Pollen accumulation in a montane region of Colorado, USA: a comparison of moss polsters, atmospheric traps, and natural basins. Review of Palaeobotany and Palynology 72, 169-197.

Flenley, J., 1973. The use of modern pollen rain samples in the study of the vegetational history of tropical regions. Pages 131-141 in Birks, H., and G. West, editors, Quaternary Plant Ecology. Blackwell, Oxford.

Giesecke, T., S. Fontana, W. Knaap, H. Pardoe, and I. Pidek, I. 2010.From early pollen trapping experiments to the Pollen Monitoring Programme. Vegetation History and Archaeobotany 19, 247-258.

Gosling, W., F. Mayle, T. Killeen, M. Siles, L. Sanchez, and S. Boreham. 2003. A simple and effective methodology for sampling modern pollen rain in tropical environments. The Holocene 13, 613-618.

Gosling, W., F. Mayle, N. Tate, and T. Killeen. 2005.Modern pollen-rain characteristics of tall terra firme moist evergreen forest, southern Amazonia. Quaternary Research 64, 284-297.

Gosling, W., F. Mayle, N. Tate, and T. Killeen. 2009.Differentiation between Neotropical rainforest, dry forest, and savannah ecosystems by their modern pollen spectra and implications for the fossil pollen record. Review of Palaeobotany and Palynology 153, 70-85.

Grimm, E. 1987. CONISS: A Fortran 77 program for stratigraphically constrained cluster analysis by the method of the incremental sum of squares. Computer and Geosciences 13-35.

Hammer, Ø., D. Harper, and P. Ryan. 2001. Past: Paleontological Statistics Software Package for Education and Data Analysis. Palaeontologica Electronica 4, 1-9.

Hansen, B., D. Rodbell, G. Seltzer, B. Leon, K. Young, and M. Abbott. 2003. Late-glacial and Holocene vegetational history from two sites in the western Cordillera of southwestern Ecuador. Palaeogeography, Palaeoclimatology, Palaeoecology, 194, 79-108.

Hicks, S., B. Ammann, M. Latalowa, H. Pardoe, and H. Tinsley. 1996. European Pollen Monitoring Programme. Project description and Guidelines. Oulu University Press.

Hicks, S., H. Tinsley, A. Huusko, C. Jensen, M. Hättestrand, A. Gerasimides, and E. Kvavadze. 2001. Some comments on spatial variation in arboreal pollen deposition: first records from the Pollen Monitoring Programme (PMP). Review of Palaeobotany and Palynology $117,183-194$.

Holmes, P. 1994. The sorting of spores and pollen by water: experimental and field evidence. Pages 9-31 in A. Traverse, editor. Sedimentation of organic particles. Cambridge University Press, Cambrigde.

Homeier, J., F. Werner, R. Gradstein, S.-W. Breckle, and M. Richter. 2008. Potential vegetation and floristic composition of Andean forests in South Ecuador, with a focus on the RBSF. Pages 87-108 in: E. Beck, J. Bendix, I. Kottke, F. Makeschin, and R. Mosandl, editors. Gradients in a Tropical Mountain Ecosystem of Ecuador. Springer, Berlin.

Hooghiemstra, H. 1984. Vegetation and Climatic History of the High Plain of Bogota, Colombia., Dissertationes Botanicae. J. Cramer, Vaduz. 
Jantz, N., and H. Behling, .2011. A Holocene environmental record reflecting vegetation, climate, and fire variability at the Páramo of Quimsacocha, southwestern Ecuadorian Andes. Vegetation History and Archaeobotany, 21, 169-185.

Jones, H., F. Mayle, R. Pennington, and T. Killeen. 2011. Characterisation of Bolivian savannah ecosystems by their modern pollen rain and implications for fossil pollen records. Review of Palaeobotany and Palynology 164, 223-237.

Krebs, C. 1989. Ecological Methodology. Harper \& Row, New York.

Lisitsyna, O., S. Hicks, and A. Huusko. 2011. Do moss samples, pollen traps and modern lake sediments all collect pollen in the same way? A comparison from the forest limit area of northernmost Europe. Vegetation History and Archaeobotany 21,187-199.

Maher, L. 1981. Statistics for microfossil concentration measurements employing samples spiked with marker grains. Review of Palaeobotany and Palynology 32, 153-191.

Niemann, H., C. Brunschön, and H. Behling. 2010. Vegetation/modern pollen rain relationship along an altitudinal transect between 1920 and 3185ma.s.l. in the Podocarpus National Park region, southeastern Ecuadorian Andes. Review of Palaeobotany and Palynology 159, 69-80.

Olivera, M., J. Duivenvoorden, and H. Hooghiemstra. 2009. Pollen rain and pollen representation across a forest-páramo ecotone in northern Ecuador. Review of Palaeobotany and Palynology 157, 285-300.

Ortuño, T., M.-P. Ledru, R. Cheddadi, A. Kuentz, C. Favier, and S. Beck. 2011.Modern pollen rain, vegetation and climate in Bolivian ecoregions. Review of Palaeobotany and Palynology $165,61-74$.

Pardoe, H., T. Giesecke, W. Knaap, H. Svitavská-Svobodová, E. Kvavadze, S. Panajiotidis, A. Gerasimidis, I. Pidek, M. Zimny, J. Święta-Musznicka, M. Latałowa, A. Noryśkiewicz, E. Bozilova, S. Tonkov, M. Filipova-Marinova, J. Leeuwen, and L. Kalnina. 2010. Comparing pollen spectra from modified Tauber traps and moss samples: examples from a selection of woodlands across Europe. Vegetation History and Archaeobotany 19, 271-283.

Roubik, D., and J. Moreno. 1991. Pollen and Spores of Barro Colorado Island. Monographs in Systematic Botany. Missouri Botanical Garden, St. Louis, Missouri.

Tauber, H., 1974. A static non-overload pollen collector. New Phytologist 73, 359-369.

terBraak, C., and P. Šmilauer. 2002. CANOCO Reference manual and CanoDraw for Windows User's Guide: Software for Canonical Community Ordination (version 4.5). Microcomputer Power. ed. Ithaka NY, USA.

Wilmshurst, J., and M. McGlone. 2005. Origin of pollen and spores in surface lake sediments: Comparison of modern palynomorph assemblages in moss cushions, surface soils and surface lake sediments. Review of Palaeobotany and Palynology 136, 1-15. 


\section{CHAPTER 5}

Inter-annual and local variability in pollen accumulation rates of the Andean forests of southern

\section{Ecuador}

Nele Jantz ${ }^{1}$, Jürgen Homeier, \& Hermann Behling ${ }^{1}$

${ }^{1}$ Department of Palynology and Climate Dynamics, Albrecht-von-Haller Institute for Plant Sciences, University of Göttingen, 37073 Göttingen, Germany

${ }^{2}$ Department of Plant Ecology, Albrecht-von-Haller Institute for Plant Sciences, University of Göttingen, 37073 Göttingen, Germany 


\section{Key words}

Palynology, pollen trap, tropical mountain vegetation, phenology

\section{Abstract}

Paleoecological reconstructions using palynological datasets require information about the present pollen vegetation relationship. The calculation of pollen accumulation rates is valuable for obtaining quantitative and unbiased data that meet the requirements for detailed analyses of variation within spatial and temporal frames. For this study, we analysed three years of modern pollen rain data using Behling pollen traps from the three tropical Andean forest types of south Ecuador: Premontane forest (PMF), lower montane forest (LMF) and upper montane forest (UMF). For each forest type, we counted 6 traps per topographic position (lower slope, mid-slope and upper slope). All of the forest types show distinguishable pollen spectra that characterise the different ecosystems. Inter-annual variation in PARs is not synchronous for all sites within one forest type, supposedly due to individual tree responses to environmental factors that influence phenological patterns or to pollen dispersal mechanisms that vary across the sites. Local variation of PARs between pollen traps within one plot can be very high due to dominance of pollen of single species. PARs are similar for Melastomataceae at all altitudes, for Clusia type and Asteraceae at LMF and UMF and for Alchornea/Alchorneopsis at PMF and LMF, making artificial zonation of pollen taxa difficult. This underlines that, especially in species-diverse tropical forest ecosystems, paleoecological calibrations using modern pollen rain data should not rely on single samples but include a wider spatial and temporal frame to account for the variability of pollen spectra within one forest type.

\subsection{Introduction}

The knowledge of dispersal characteristics and patterns of pollen taxa is important for an accurate reconstruction of paleo-environments using pollen data. Pollen percentage data have long been known to give a false impression of a linear or at least monotonous relation to vegetation data (Fagerlind 1952, Prentice and Webb 1986). However, pollen percentage data depend not only on abundance, of one specific taxon, but also on the abundance of other taxa in the pollen record (Prentice and Webb 1986). This phenomenon, also known as the Fagerlind-effect, has long been recognized and consequences for the pollen record have been shown as early as 1963 by Davis. She gave way to the modern theory of pollen analysis by creating the R-value model, which converts pollen percentages into relative tree abundances, thus taking the Fagerlind-effect into account (Davis 1963, Prentice and Webb 1986). This model has been extended and changed in many ways to create the best possible connections between vegetation and pollen percentage 
data (Prentice \& Webb, 1986; Parsons \& Prentice, 1981; Prentice, 1985; see also Giesecke et al., 2010 and references therein). However, for this analysis, detailed vegetation studies over a large transect are necessary, a prerequisite which can be fulfilled in temperate forests but would, due to high diversity and density of the vegetation, involve a very large amount of work in tropical ecosystems. The other possible solution to overcome the Fagerlind-effect for pollen data is the conversion of count data to pollen accumulation rates (PARs), which turn the data into absolute values of grains per $\mathrm{cm}^{2}$ and year. For sediment samples, problems in dating can make calculation of PARs difficult and uncertainties can be large (Bennett 1994). Nevertheless, a careful analysis of lake or peat deposits keeps their PARs in the same range as the ones of pollen traps (Hicks and Hyvärinen 1999), thus making PARs of pollen trap data important for the estimation of pollen production in a given environment which can be used for the calibration of subfossil pollen records. Whereas this fact has led to creating the pollen monitoring program in Europe (Hicks et al. 1996), studies about pollen accumulation rates have been scarce in tropical America (Behling et al. 1997, 2001, Bush and Rivera 1998, Gosling et al. 2009, Burn et al. 2010, Jones et al. 2011). In the Andes, PAR ranges for the most important taxa are still completely unknown and only few studies have estimated the total PAR for some forest types (Niemann et al. 2010) or calculated concentration values (Hansen et al. 2003, Weng et al. 2004). Due to their independence of percentage distortions and chronology errors in sediment samples, PARs are valuable for studying inter-annual changes in pollen production (Knaap et al. 2010). A high variability in annual PARs, which has been related to possible climatic factors, has been reported by many authors throughout the neotropics (Bush and Rivera 1998, Gosling et al. 2005, 2009). Phenological analyses of modern plant data from South Ecuador have detected a seasonality pattern of flowering periodicity of 8-12 months for most species, which is possibly linked to cloudiness and precipitation oscillations (Bendix et al. 2006). Other studies in the same study region made similar observations and reported on a high intraspecific synchronisation (Cueva Ortiz et al. 2006, Günter et al. 2008). However, not only abiotic environmental conditions, but also biological interactions on an intra- or interspecific level, such as competition, can influence phenological patterns in plants (Sakai 2001). In our study, which covers three years of modern pollen rain collection using Behling traps (Jantz et al. 2013), we analyse the PARs of some of the characteristic taxa in the pollen rain spectra of three different north-central Andean forest types of southern Ecuador: Premontane forest, lower montane forest and upper montane forest. We want to test whether pollen traps can be used as a remote sensing tool for the detection of inter-annual variations in flowering patterns of characteristic taxa for the different forest types. We address three main research questions: 
1. What are the pollen accumulation rates for characterising pollen taxa of the north-central Andean forests?

2. Do any of the characteristic pollen taxa show strong inter-annual variations in their pollen accumulation rates (PARs)?

3. How strong is the influence of the pollen trap distribution on the pollen spectra?

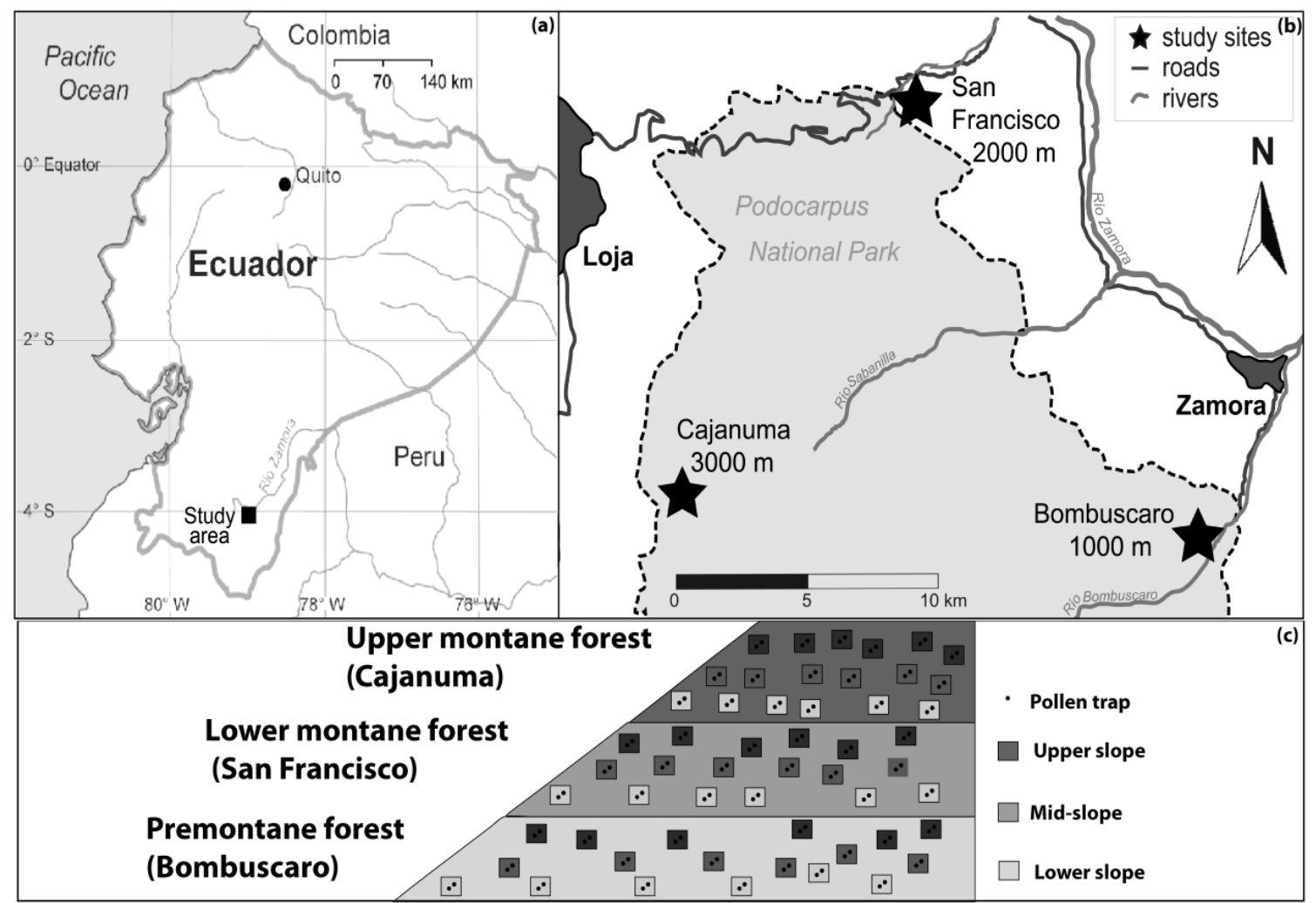

Figure 8 a) location of the study area in Ecuador, b) location of the study sites in the Podocarpus National Park, c) Sampling design of the experiment. Six $400 \mathrm{~m}^{2}$ plots have been established at each slope position, resulting in 18 plots for each forest type. Two pollen traps were distributed in each plot.

\subsection{The study region}

As a study region, we chose the Podocarpus National park and the nearby Reserva Biológica San Francisco, which are located in the eastern Cordillera of the Andes in South Ecuador, in the provinces of Loja and Zamora-Chinchipe. Three different study sites were located along an altitudinal gradient spanning from ca. 1000 to ca. $3000 \mathrm{~m}$ a.s.l. to cover three different forest types, which are described as follows (see also Fig. 1a and b):

\section{Premontane forest (PMF, Bombuscaro)}

The PMF at Bombuscaro is located at the eastern side of the Podocarpus National Park, close to the city of Zamora $\left(04^{\circ} 06^{\prime} \mathrm{S}, 78^{\circ} 58^{\prime} \mathrm{W} ; 1020-1270 \mathrm{~m}\right.$ a.s.l.). The most characteristic taxa belong 
to the families of Arecaceae, Bombacaceae, Combretaceae, Lecythidaceae, Moraceae, Myristicaceae, Piperaceae, Rubiaceae and Sapotaceae and trees can grow up to $40 \mathrm{~m}$ in height (Homeier et al. 2008).

\section{Lower montane forest (LMF, San Francisco)}

The studied LMF belongs to the Reserva Biológica San Francisco, which is situated at the northeastern fringe of the Podocarpus National Park (03 58' S, 79 04' W, 1910 to 2090 m a.s.I.). Important tree families for this forest type are Alazateaceae, Arecaceae, Asteraceae, Bignoniaceae, Clusiaceae, Cyatheaceae, Fabaceae (Mimosioidae), Lauraceae, Malvaceae, Melastomataceae, Meliaceae, Moraceae, Piperaceae (Homeier et al. 2008). Tree heights are up to $30 \mathrm{~m}$.

\section{Upper montane forest (UMF, Cajanuma)}

The UMF is situated at the western side of the Podocarpus National Park $\left(04^{\circ} 06^{\prime} \mathrm{S}, 7^{\circ} 11^{\prime} \mathrm{W}\right.$; 2800-2900 m a.s.I.), at about $15 \mathrm{~km}$ distance to the city of Loja. Tree heights can be up to 6-8m, rarely higher. Important tree families for this forest type are Aquifoliaceae, Bromeliaceae, Chloranthaceae, Clethraceae, Clusiaceae, Cunoniaceae, Ericaceae, Grossulariaceae, Iridaceae, Lauraceae, Loranthaceae, Melastomataceae, Myrtaceae, Rosaceae, Styracaceae, Symplocaceae, Theaceae and Poaceae (Homeier et al. 2008).

\subsection{Climate}

The climate of the research area is tropical humid with a wet season from April to July and a less humid period from September to December (Emck 2007, Bendix et al. 2008). A pronounced dry season does not exist. Temperatures vary from $19.4^{\circ} \mathrm{C}$ at Bombuscaro (ca. $1000 \mathrm{~m}$ a.s.l.) to 9.4 at Cajanuma (3000 m a.s.l.) (Bendix et al. 2008). Precipitation increases from ca. $2000 \mathrm{~mm} / \mathrm{year}$ at $1000 \mathrm{~m}$ a.s.I., to $1950 \mathrm{~mm}$ at $2000 \mathrm{~m}$ a.s.l. and $4500 \mathrm{~mm}$ at $3000 \mathrm{~m}$ a.s.l (Moser et al. 2007, Bendix et al. 2008). The tropical trade wind regime is the dominant wind pattern, bringing strong easterlies throughout the year (Beck et al. 2008). However, local influences lead to different wind patterns and irregularities at the different study sites. Whereas the UMF at Cajanuma is mostly dominated by the southeasterly trade winds, which can turn into north-west winds at the lee sides of the mountains due to turbulence and friction caused by irregular canopy surface (Richter et al. 2008), the areas of San Francisco and possibly also Bombuscaro are more influenced by a moderate to fresh along-valley southwesterly breeze with downstream movements, which seems to be less uniform and adynamic at Bombuscaro (Emck 2007). 


\subsection{Methods}

\subsubsection{Vegetation analysis}

For vegetation analysis, we established six $20 \times 20 \mathrm{~m}$ plots on each of the three slope positions (lower slope, mid-slope and upper slope) for each of the tree forest types PMF, LMF and UMF, resulting in a total of 54 vegetation plots. Within the plots, all trees with a DBH> $5 \mathrm{~cm}$ were recorded and measured (see Fig. $1 \mathrm{c}$ ).

\subsubsection{Pollen Traps}

For the modern pollen rain analysis, we used Behling traps (see Jantz et al. 2013b). We distributed two traps at the centre of each plot in November 2009. We exchanged the traps each year around the same date in October of each year.

\subsubsection{Pollen analysis}

We counted one trap of each plot up to at least 300 pollen grains. In the first year, we excluded taxa with an abundance of $>50 \%$ in the pollen data from the pollen sum. When a trap could not be refound, the other trap from the same plot was counted in the following year. In the first year, both traps of the UMF plots where counted to record differences in PARs within the same site. In the first year one tablet of $18583 \pm 762$ exotic Lycopodium clavatum spores was added to the trap content, in year two and tree tablets of $20484 \pm 1546$, respectively. Traps BO-LS 2, BO-LS 3, BO- MS 1, BO- MS 2, BO- MS 5 and BO- US 3 of year two only contain two tablets of Lycopodium clavatum spores. We calculated percentages as well as PARs for each year using the program TILIA (Grimm 1987) and depicted the results using $C^{2}$ (Juggins 2003). Errors of PARs due to Lycopodium clavatum spores and pollen counts were calculated using the formula of Mosiman (1965)(Maher 1981):

$$
U_{L}=\frac{\hat{\mathrm{u}}+Z^{2} /(2 n) \pm Z \text { û } 1+\hat{\mathrm{u}} / n+Z^{2} / 4 n^{2} \quad 0.5}{1-Z^{2} / n}
$$

with

$$
\hat{\mathrm{u}}=x / n
$$

with $\mathrm{u}$ being the true ratio between the number of pollen and Lycopodium spores, $\mathrm{x}$ being the pollen count of a specific sample, $\mathrm{n}$ being the number of Lycopodium clavatum spores counted and $Z$ being the standard deviation unit under the standard normal curve. We chose a confidence limit of 0.95 for $u$, which leads to $Z=1.960$. However, because we combined the counting error with the independent error for the amount of Lycopodium clavatum spores added to the sample, 
we could decrease the overall confidence limit to $77.6 \%$, corresponding to $Z=1.19$. The estimated error for each PAR can be calculated as follows:

$$
U_{L G e s}=\frac{U_{L} * M+S E_{M}}{A}
$$

Where $M$ is the total number of Lycopodium clavatum spores in the sample which has the standard error SE and $\mathrm{A}$ is the area of the pollen trap opening.

For the calculation of the average for each slope position, we excluded the samples which had one trap missing for one of the three years. 95\% confidence intervals were calculated for each average PAR.

\subsection{Results}

All samples of each site contain distinct pollen spectra that mark different forest types. An average of the PARs of selected taxa with 95\% intervals can be seen in Table 1.

Table 4 Average PARs for each forest type with 95\% confidence intervals in brackets.

\begin{tabular}{l|l|l|l} 
Taxon & PMF (Bombuscaro) & $\begin{array}{l}\text { LMF } \\
\text { (San Francisco) }\end{array}$ & UMF (Cajanuma) \\
\hline Alchornea & $595.4(43.9)$ & $415.4(103.2)$ & $62.3(7.7)$ \\
Alnus & $2.1(0.7)$ & $37.4(5.9)$ & $368.2(30.1)$ \\
Asteraceae & $257.6(37)$ & $476.6(37.9)$ & $338.9(90.6)$ \\
Clusia type & $13.3(4.7)$ & $247.9(60.7)$ & $330.8(44.3)$ \\
Clethra type & 0.0 & $812.5(211.4)$ & $178.3(42.2)$ \\
Hedyosmum & $415.4(60.7)$ & $1111.9(109.5)$ & $580.5(53.6)$ \\
Hieronyma & $33.4(11.3)$ & $476.6(57.7)$ & $1.4(0.8)$ \\
Melastomataceae/Combretaceae & $2375.8(578.6)$ & $3852.6(355.4)$ & $3821.9(718.6)$ \\
Moraceae/Urticaceae & $13429.9(1177.4)$ & $30721.3(4251.3)$ & $666.3(101.0)$ \\
Myrsine & $39.3(6.3)$ & $203.8(21.7)$ & $1216.7(332.5)$ \\
Myrica & $7.1(1.9)$ & $178.0(28)$ & $276.0(34.7)$ \\
Piperaceae & $397.4(56.9)$ & $893.8(128.5)$ & $98.3(32.8)$ \\
Tapirira & $356.7(62.1)$ & 0.0 & 0.0 \\
Weinmannia & $10.6(2.4)$ & $643.8(107.9)$ & $2950.1(321.1)$ \\
Total Pollen Accumulation & $\mathbf{2 0 1 0 3 . 3 ( 1 3 5 0 . 6 )}$ & $\mathbf{4 4 1 8 7 . 8 ( 4 2 8 1 . 8 )}$ & $\mathbf{1 2 4 9 1 . 6 ( 9 9 3 . 2 )}$
\end{tabular}




\subsubsection{Upper Montane Forest - Cajanuma}

\section{Percentages}

A percentage diagram of the most important taxa is shown in Fig. 2. A complete diagram of the pollen spectra of the Behling traps can be seen in the Appendix 1. In the pollen spectra of the UMF in Cajanuma, Melastomataceae and Weinmannia are generally the dominant taxa. Pollen of Melastomataceae seem to be more dominant in traps of mid- and especially upper slopes, whereas pollen of Weinmannia is relatively abundant throughout the different slopes. In traps of LS 1 , Myrsine reaches values of up to $>70 \%$ in all three years. Pollen of Hedyosmum is present with proportions between $0-10 \%$, reaching higher values between 20 and $40 \%$ in the traps of LS 5 and MS 1. Pollen of Myrica is found with similar proportions in the traps of MS 1 and MS 3. Pollen of Poaceae reaches values between 10-20\% in the traps of MS 4, MS 5, MS 6, US 1 and US 2. Pollen of Alnus is present with proportions of up to $10 \%$ in the traps of MS 4, MS 5, MS 6 as well as US 4 and US 5. Asteraceae pollen show a single peak in abundance in year 3 of LS 2 where it reaches percentages values of 41 . Pollen grains of Podocarpaceae, Clusia type, Clethra type and Lauraceae are found at many sites with a low abundance of generally between $0-5 \%$. Fern spores are present at all altitudes but more frequent with proportions of up to $10 \%$ at LS 2 , LS 3, LS 4, LS 5 and LS 6.

\section{Pollen accumulation rates (PARs)}

A diagram with the PARs of selected taxa with their errors due to pollen and Lycopodium clavatum spore counts is shown in Figure 3. Generally, especially high PARs obtain have large errors and should thus be regarded cautiosly. The total PARs in the UMF of Cajanuma vary from 2650 pollen grains $/ \mathrm{cm}^{2}$ year ${ }^{-1}$ in MS 1.1 (2009-2010)- 49,000 pollen grains $/ \mathrm{cm}^{2}$ year $^{-1}$ in MS 5.1 (2009-2010), with an average at ca. 12,500 pollen grains $/ \mathrm{cm}^{2}$ year ${ }^{-1}$. The highest pollen producing taxon is Melastomataceae with values ranging from ca. 300 (LS 6 in 2010-2011) - 40,000 pollen grains $/ \mathrm{cm}^{2}$ year ${ }^{-1}$ (US 3 in 2009-2010). PARs of Melastomataceae shows pronounced peaks at MS 2.3 (2011-2012, 18,000 compared to 500 and 1000 pollen grains $/ \mathrm{cm}^{2}$ year $^{-1}$ in 2009-2010 and 2010-2011, respectively), MS 4.2 (2010-2011, 9600 compared to 1500 pollen grains/cm² year $^{-1}$ in 2011-2012), as well as at MS 5.1 (24,000 pollen grains/ $\mathrm{cm}^{2}$ year ${ }^{-1}$ in 2009-2010 compared to 600 and 1100 pollen grains $/ \mathrm{cm}^{2}$ year ${ }^{-1}$ in 2010-2011 and 2011-2012). Myrsine shows very high PARs of $10,000-20,000$ pollen grains $/ \mathrm{cm}^{2}$ year ${ }^{-1}$ in LS 1 , but has usually less high values of between 0 and 3000 pollen grains $/ \mathrm{cm}^{2}$ year ${ }^{-1}$. PARs of Weinmannia have values of between 60 and 8000 pollen grains $/ \mathrm{cm}^{2} \quad$ wear ${ }^{-1} \quad$ with $\quad$ peaks of ca. 


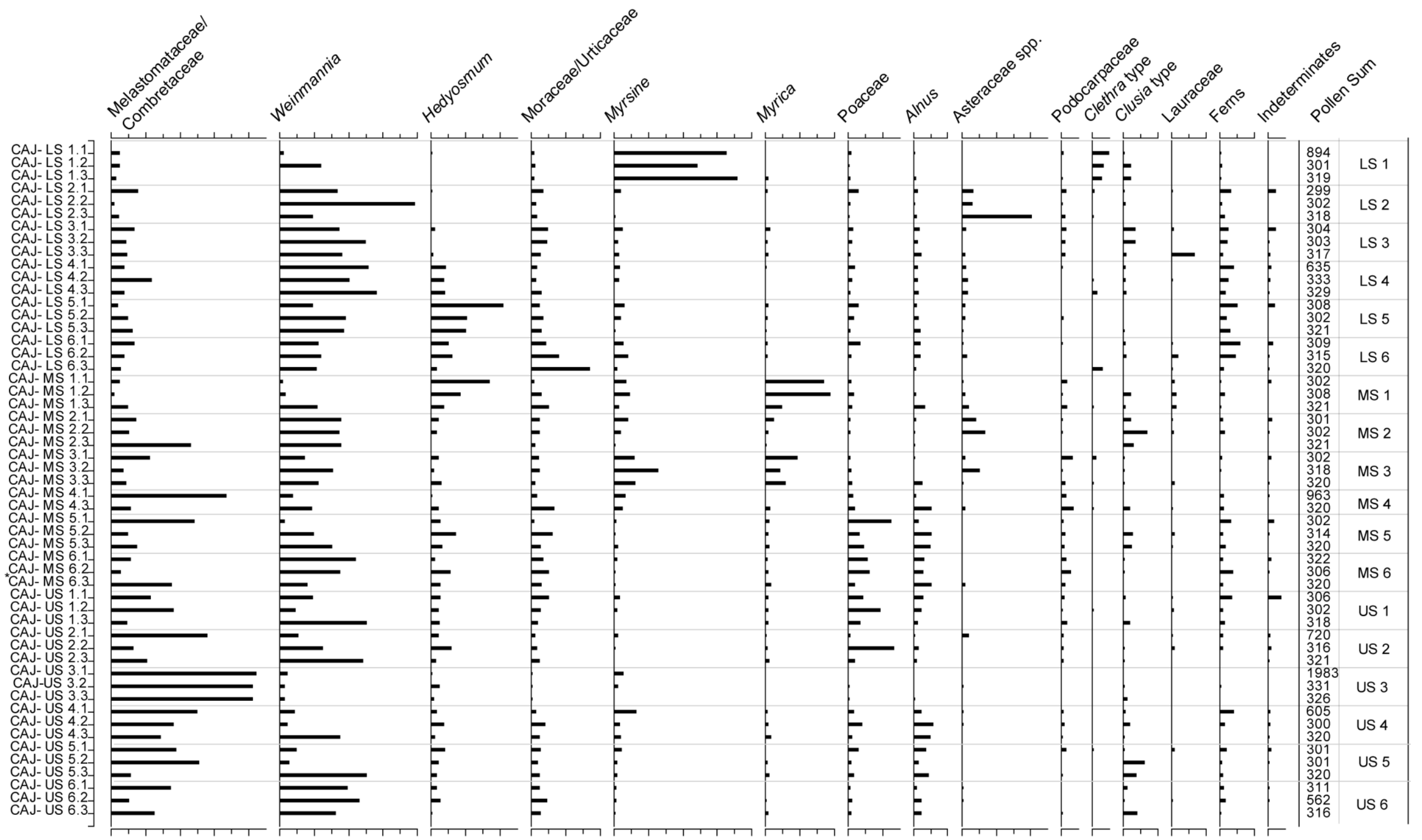

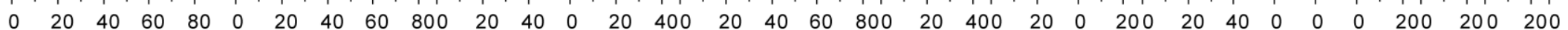

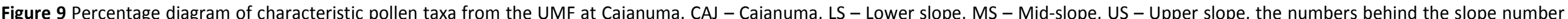
represent the period in which the pollen trap collected pollen: 1 - 2009-2010, 2-2010-2011, 3-2011-2012. The asterisk marks the samples where a different trap was counted for the same plot. 


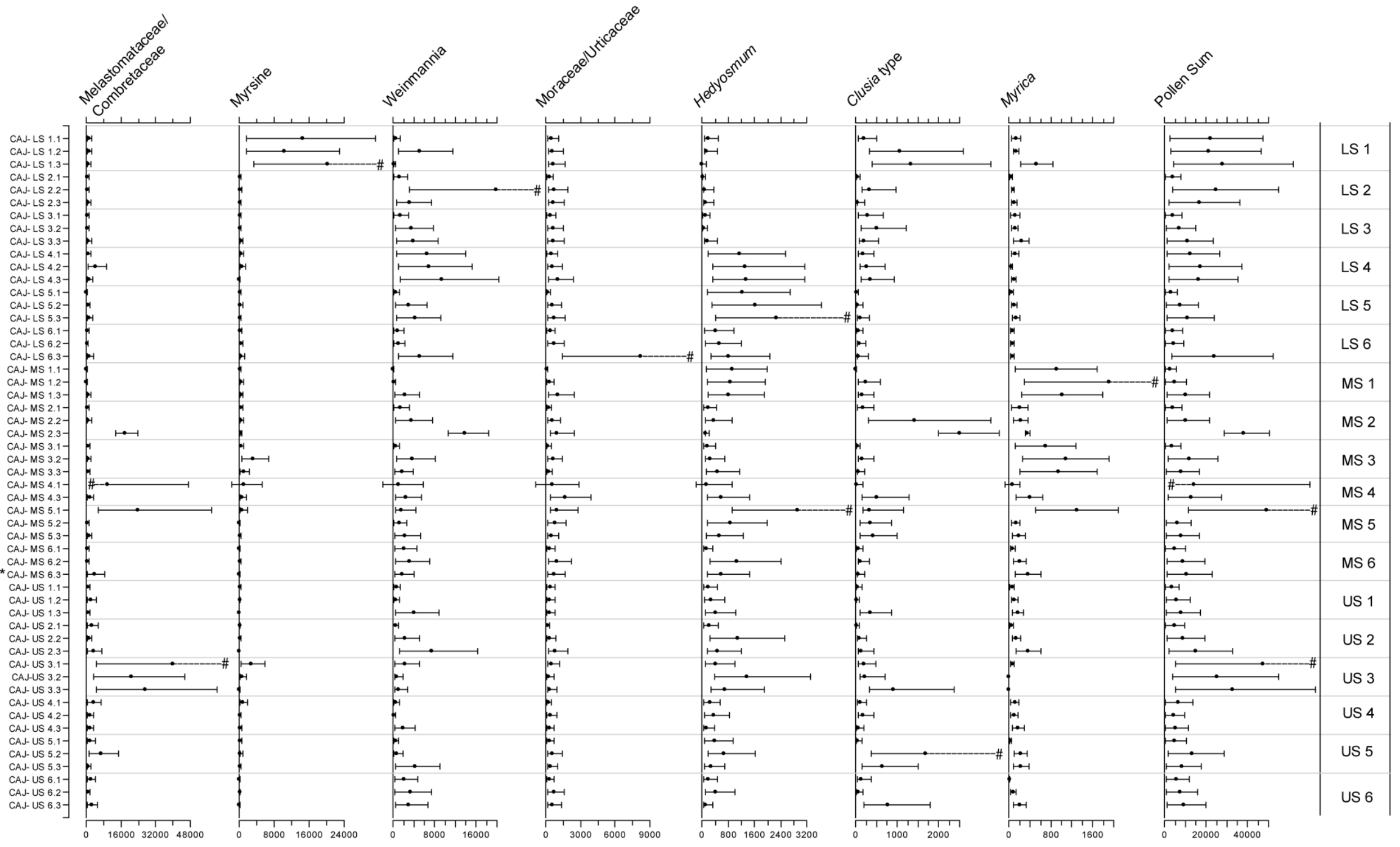

Figure 10 Pollen accumulation rates for characteristic taxa of the UMF at Cajanuma. Error bars represent the counting errors of pollen grains and Lycopodium marker spores based on Mosiman

(1965). CAL - Cajanuma, LS - Lower slope, MS - Mid-slope, US - Upper slope, the numbers behind the slope number represent the period in which the pollen trap collected pollen: $1-2009-2010$

$2-2010-2011,3-2011-2012$. The asterisk marks the samples where a different trap was counted for the same plot. The number sign marks high errorbars that are not displayed in their totality. 
Melastomataceae/Combretaceae

Hedyosmum

Weinmannia

CAJ- US 2011-2012
CAJ- US 2010-2011
CAJ- US 2009-2010
CAJ-MS 2011-2012
CAJ-MS 2010-2011
CAJ-MS 2009-2010
CAJ- LS 2011-2012
CAJ- LS 2010-2011
CAJ- LS 2009-2010 $10000 \quad 20000 \quad 30000$

CAJ- US 2011-2012

CAJ- US 2010-2011

CAJ- US 2009-2010

CAJ-MS 2011-2012

CAJ-MS 2010-201

CAJ-MS 2009-2010

CAJ- LS 2011-2012

CAJ-LS 2010-2011

CAJ- LS 2009-2010

\begin{tabular}{lll}
\hline & \\
\hline & $1000 \quad 2000$ & 3000 \\
grains $/ \mathrm{cm}^{2} /$ year
\end{tabular}

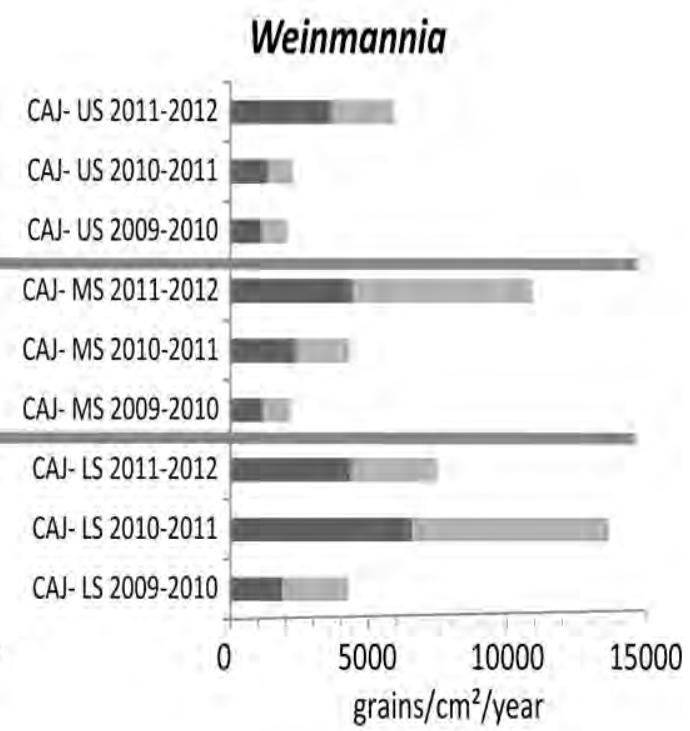

Myrsine

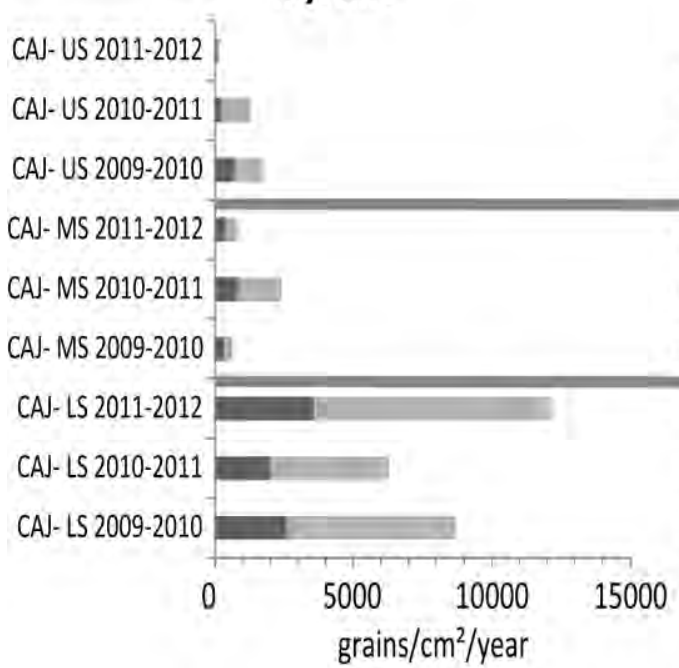

Myrica

Moraceae/Urticaceae

CAJ- US 2011-2012

CAJ- US 2010-2011

CAJ- US 2009-2010

CAJ-MS 2011-2012 CAJ-MS 2011-2012

CAJ-MS 2010-2011

CAJ-MS 2009-2010

-

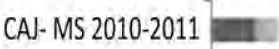

CAJ- MS 2009-2010

CAJ- LS 2011-2012 름

CAJ- LS 2011-2012

CAJ- LS 2010-2011

CAJ- LS 2009-2010

CAJ- LS 2010-2011

CAJ- LS 2009-2010

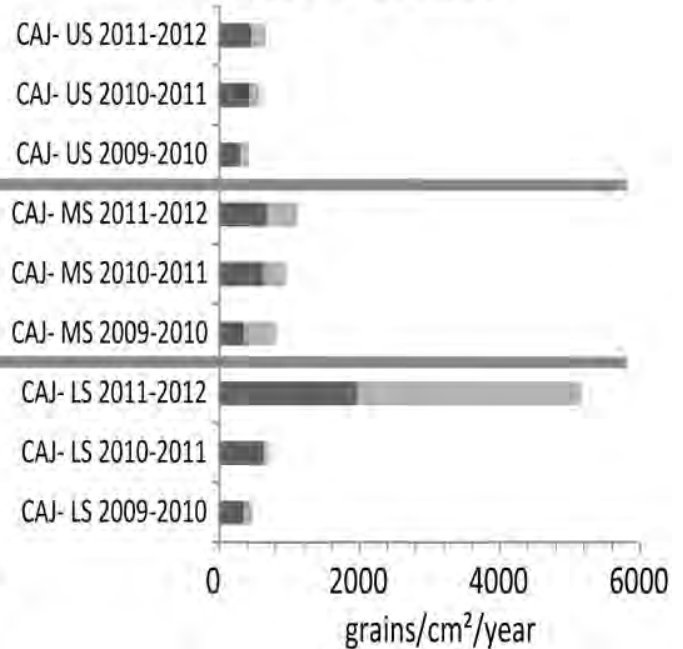

Figure 11 Average pollen accumulation rates (grains $\mathrm{cm}^{-2} \mathrm{yr}^{-1}$ ) for selected taxa for the UMF at Cajanuma with $95 \%$ confidence intervals. Data is given for each slope and year (marked in grey). LS - Lower slope, MS - Mid-slope, US - Upper slope. 
14,000 and 18,000 pollen grains/cm² year ${ }^{-1}$ in LS 2.2 and MS 2.2 (2010-2011), respectively. PARs of Moraceae/Urticaceae range between 150 and 1700 pollen grains $/ \mathrm{cm}^{2}$ year ${ }^{-1}$, with 8200 pollen grains $/ \mathrm{cm}^{2}$ year ${ }^{-1}$ at LS 6.3 (2011-2012). Hedyosmum and Myrica show PARs of between 0 and 3000 and 0 and 1200 pollen grains $/ \mathrm{cm}^{2}$ year ${ }^{-1}$. Pollen of Hedyosmum shows slight PAR peaks at MS 5.1 (2009-2010), MS 6.2, US 2.2 and US 3.2(2010-2011). Pollen grains of Myrica have are abundant at LS 1.3 (2011-2012) and MS 5.1 (2009-2010). Figure 4 shows the average PAR for selected taxa per slope and year with 95\% confidence intervals. The data shows no pronounced peaks for the recorded taxa. Differences between the localities seem to be higher than differences between different years of one locality. Slight peaks between the years can be seen for Moraceae/Urticaceae values LS 2011-2012, Weinmannia US and MS 2011-2012, as well as Melastomataceae/Combretaceae PARs of MS 2009-2010 and 2011-2012 compared to 2010-2011. Figure 5 shows the variability of PARs of selected pollen taxa within the same year at the same plot, where both traps were counted. All taxa show pronounced peaks in only one of the two traps, e.g. Melastomataceae/Combretaceae in traps MS 4a, MS 5b and US 3a, Myrsine in traps LS 1a and MS 4a, Weinmannia in trap LS 4a, Moraceae/Urticaceae in trap MS 4a, Hedyosmum in traps MS 4a, MS 5b and US 3b, and Clusia type in traps LS 3b, MS 4a and MS 5a.

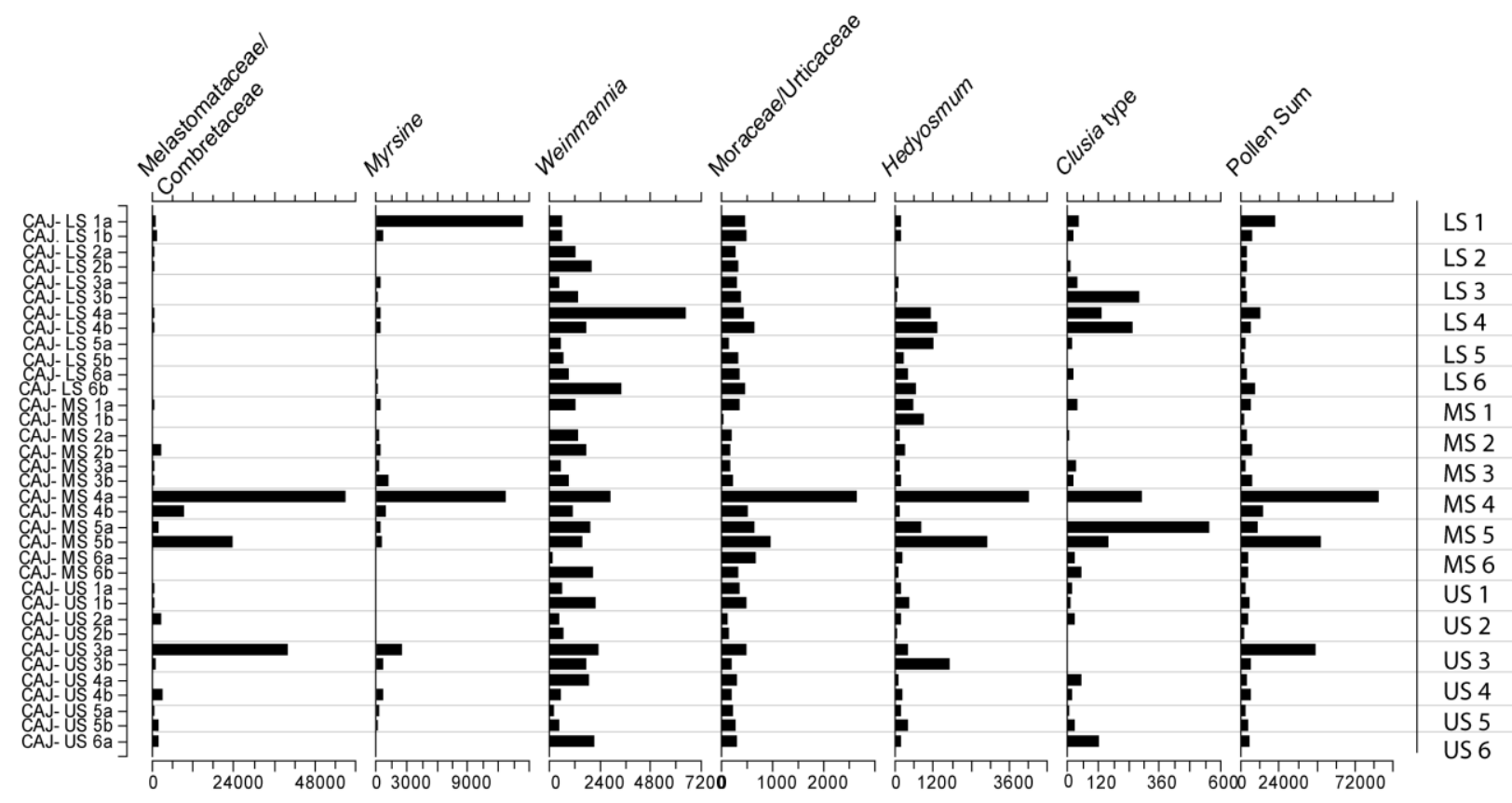

Figure 12 Variability of pollen accumulation rates (grains $\mathrm{cm}^{-2} \mathrm{yr}^{-1}$ ) per plot for selected taxa from the UMF at Cajanuma (2009). a) and b) mark the different traps counted for each plot. CAJ - Cajanuma, LS - Lower slope, MS - Mid- slope, US - Upper slope. 


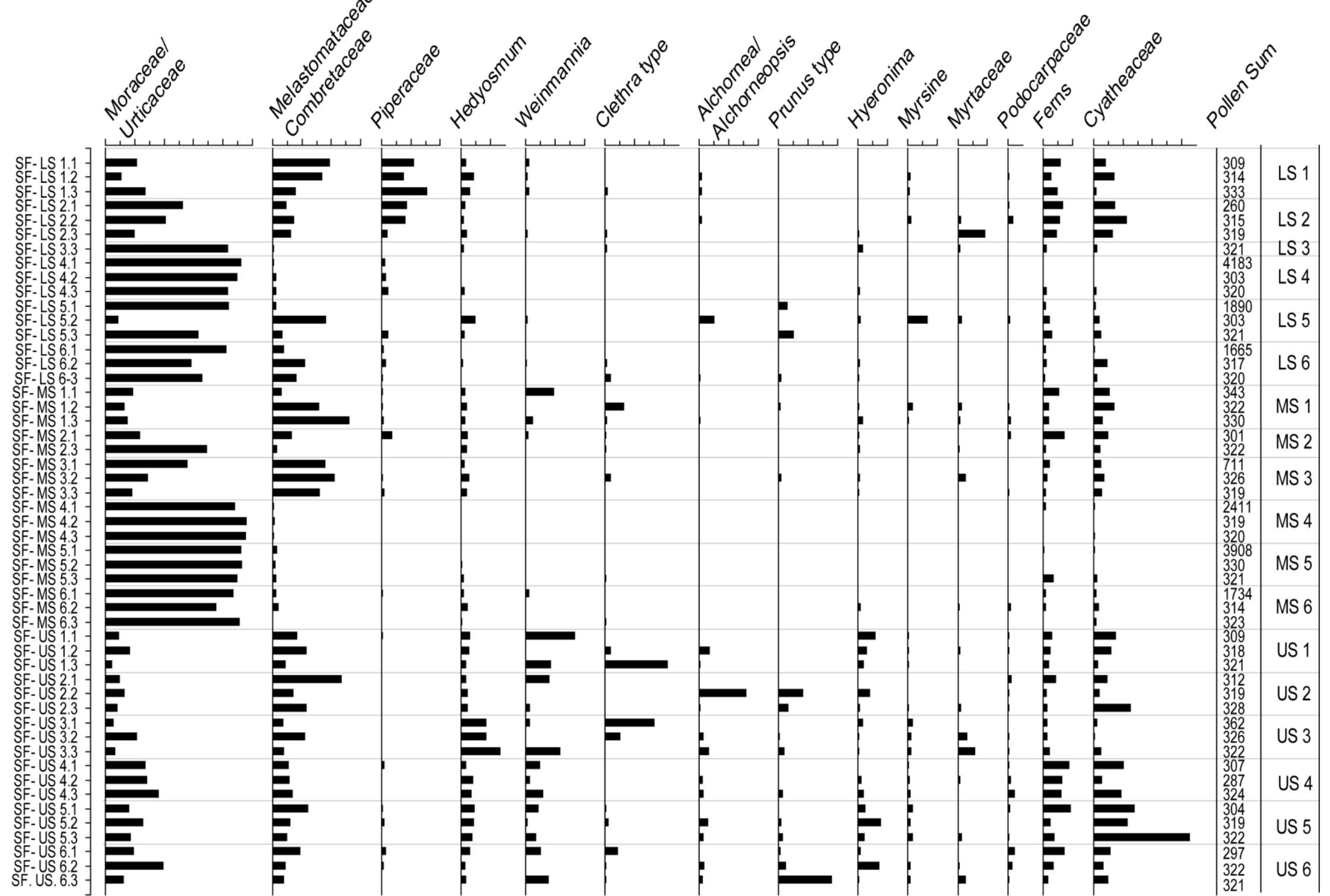

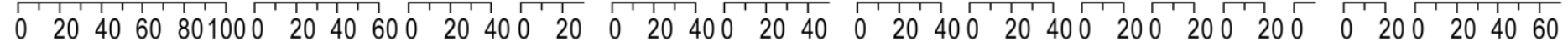

Figure 13 Percentage diagram of characteristic pollen taxa from the LMF at San Francisco. SF- San Francisco, LS - Lower slope, MS - Mid-slope, US - Upper slope, the numbers behind the slope number represent the period in which the pollen trap collected pollen: 1 - 2009-2010, 2-2010-2011, 3- 2011-2012. 


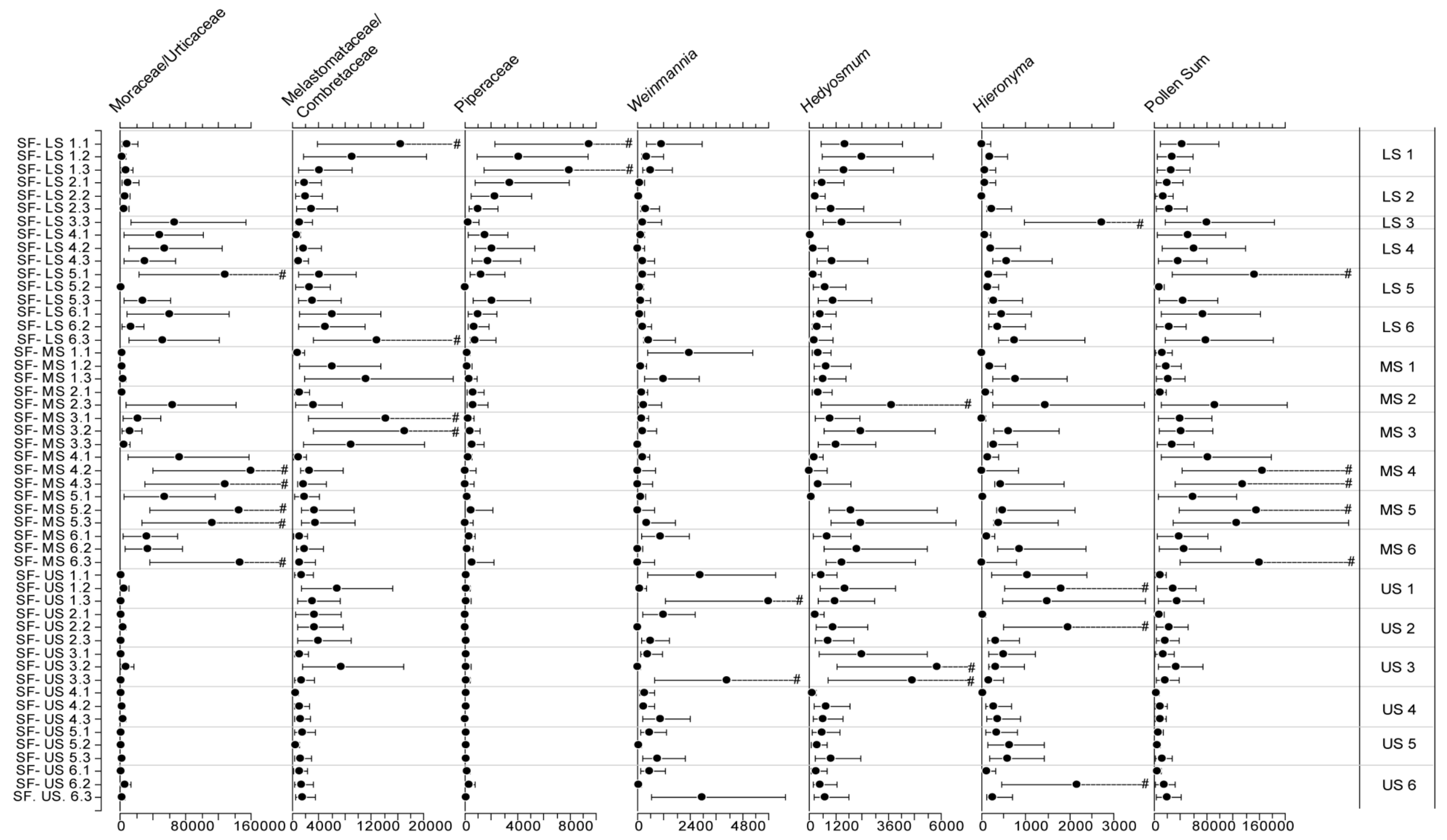

Figure 14 Pollen accumulation rates for characteristic taxa of the LMF at San Francisco. Error bars represent the counting errors of pollen grains and Lycopodium marker spores based on Mosiman (1965). SF - San Francisco, LS - Lower slope, MS - Mid-slope, US - Upper slope, the numbers behind the slope number represent the period in which the pollen trap collected pollen: 1

-2009-2010, 2 -2010-2011, 3-2011-2012. The number sign marks high errorbars that are not displayed in their totality. 


\section{Moraceae/Urticaceae}

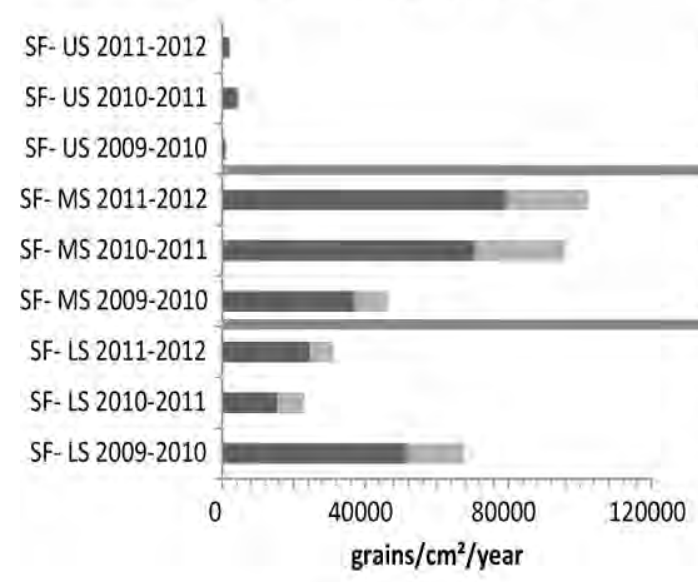

Piperaceae

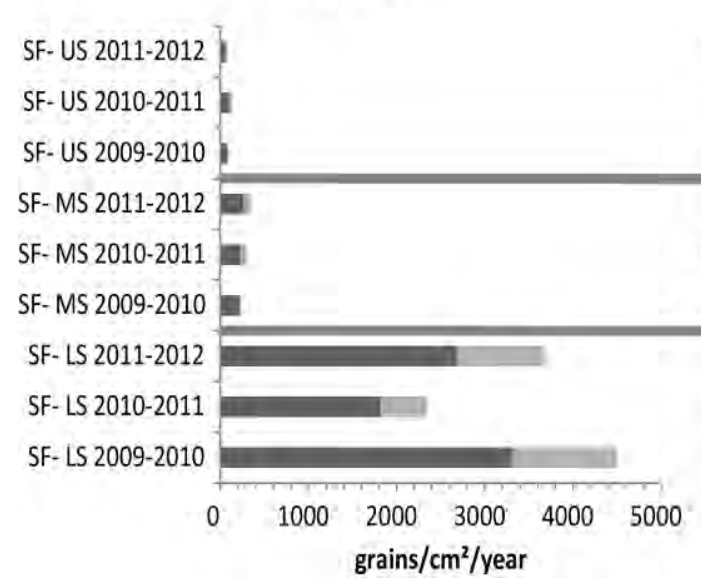

\section{Melastomataceae/Combretaceae}

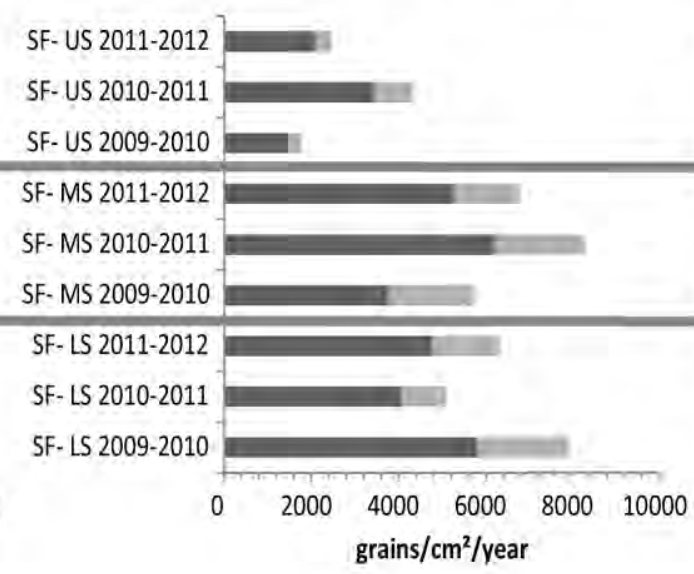

Weinmannia

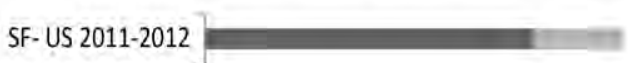

SF-US $2010-2011$

SF-US 2009-2010

SF- MS 2011-2012

SF-MS 2010-2011

SF-MS 2009-2010

SF- LS 2011-2012

SF- LS 2010-2011

SF- LS 2009-2010

\section{II}

0

$1000 \quad 2000 \quad 3000$
grains $/ \mathrm{cm}^{2} /$ year

\section{Hedyosmum}

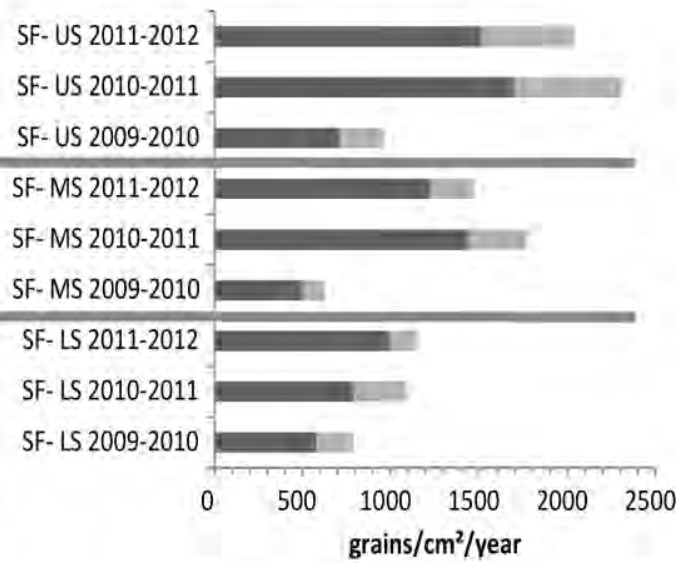

Hieronyma

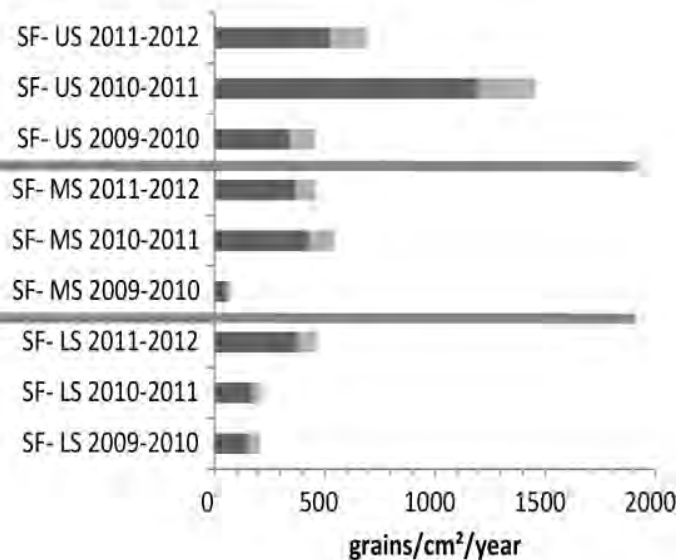

Figure 15 Average pollen accumulation rates (grains $\mathrm{cm}^{-2} \mathrm{yr}^{-1}$ ) for selected taxa for the LMF at San Francisco with $95 \%$ confidence intervals. Data is given for each slope and year (marked in grey). LS - Lower slope, MS - Mid-slope, US - Upper slope. 


\subsubsection{Lower Montane Forest - San Francisco}

\section{Percentages}

A percentage diagram of selected taxa of the modern pollen rain from the San Francisco area can be seen in Figure 6. The most abundant pollen taxon is Moraceae/Urticaceae, with values from $10-90 \%$. Pollen grains of Moraceae/Urticaceae have especially high values in the traps of LS $3, L S$ 4, LS 5, LS 6, as well as MS 4, MS 5 and MS 6. Pollen proportions of Melastomataceae/Combretaceae reach values of about 40\% in traps of LS 1, MS 1, MS 2 and US 2. At LS 1 and LS 2, Piperaceae is an abundant pollen taxon with proportions of up to $30 \%$. Pollen of Hedyosmum reaches values of up to $20 \%$ at US 3 and about $0-10 \%$ in the other samples. Weinmannia pollen has abundance peaks at MS 1.1 (2009-2010), US 1.1 (2009-2010) and US 1.3 (2011-2012), as well as at US 3.3 (2011-2012), where percentages of 20-30 are reached. Pollen of Weinmannia is frequently found with values around $10 \%$ in upper slope samples, but rarer in lower and mid-slope samples. Pollen of Clethra type has single peaks of higher abundance with values of up to 40\% in sample US 1.3 (2011-2012) and sample US 3.1 (2009-2010). Pollen of the taxa Alchornea/Alchorneopsis, Prunus type, Hieronyma, Myrsine, Myrtaceae and Podocarpaceae have values from $0-10 \%$ in most of the samples but reach single peaks of between $30-40 \%$ (Alchornea/Alchorneopsis and Prunus type) or 10-20\%, respectively (Hieronyma, Myrsine, Myrtaceae and Podocarpaceae). Ferns (without Cyatheaceae) and Cyatheaceae have higher values throughout the pollen samples of the San Francisco area, but show especially high proportions at the upper slope samples (ca. 5 to 15\% for Ferns without Cyatheaceae and ca. 2$>60 \%$ for Cyatheaceae).

\section{Pollen accumulation rates (PARs)}

PARs of selected taxa per site and year are shown in Fig. 7. The total PARs for the San Francisco area are high with values ranging from 3400 pollen grains $/ \mathrm{cm}^{2}$ year ${ }^{-1}$ (US 4.1, 2009-2010) to 166,000 pollen grains $/ \mathrm{cm}^{2}$ year ${ }^{-1}$ (LS MS 4.1, 2009-2010), with an average of ca. 44200 grains $/ \mathrm{cm}^{2}$ year $^{-1}$. As for percentages, Moraceae/Urticaceae have the highest PARs in the San Francisco area, with values from ca. 700 to ca. 160,000 pollen grains $/ \mathrm{cm}^{2}$ year $^{-1}$. Maxima are reached at LS 3 (ca. 7000 pollen grains $/ \mathrm{cm}^{2}$ year ${ }^{-1}$ ), LS 4 (ca. 30,000-55,000 pollen grains $/ \mathrm{cm}^{2}$ year ${ }^{-1}$ ), LS 5.1 (20092010 , ca. 128,000 pollen grains/cm² year ${ }^{-1}$ ), LS 6.1 (2009-2010, ca. 60,000 pollen grains/cm ${ }^{2}$ year $\left.{ }^{1}\right)$ and $6.3\left(2011-2012\right.$, ca. 53,000 pollen grains $/ \mathrm{cm}^{2}$ year $\left.^{-1}\right)$, as well as at MS 2.3 $(64,000$ pollen grains $/ \mathrm{cm}^{2}$ year $\left.{ }^{-1}\right)$, MS $4\left(62,000-160,000\right.$ pollen grains $/ \mathrm{cm}^{2}$ year $\left.{ }^{-1}\right)$, MS $5(54,000-155,000$ pollen grains $/ \mathrm{cm}^{2}$ year $\left.{ }^{-1}\right)$ and MS $6 \quad\left(33,000-14,6000\right.$ pollen grains $/ \mathrm{cm}^{2}$ year $\left.{ }^{-1}\right)$. Melastomataceae/Combretaceae show PARs from 500 to ca. 17,000 pollen grains $/ \mathrm{cm}^{2}$ year ${ }^{-1}$. 
Highest PARs for Melastomataceae/Combretaceae occur in LS 1.1 and LS 1.2 (2009-2011, ca. 9000-16,000 pollen grains/cm year $\left.^{-1}\right)$, LS $6.3\left(2011-2012\right.$, ca. 13,000 pollen grains/ $/ \mathrm{cm}^{2}$ year $\left.^{-1}\right)$, MS 1.3 (2011-2012, ca. 11,000 pollen grains $/ \mathrm{cm}^{2}$ year ${ }^{-1}$ ), MS 3 (ca. 9000-17,000 pollen grains $/ \mathrm{cm}^{2}$ year ${ }^{-1}$ ), US 1.2 (2010-2011, ca. 7000 pollen grains/cm² year $^{-1}$ ) and US 3.2 (2010-2011, ca. 8000 pollen grains $/ \mathrm{cm}^{2}$ year ${ }^{-1}$ ). Piperaceae have high PARs only in the lower slope sites. Highest values of up to ca. 9400 pollen grains $/ \mathrm{cm}^{2}$ year ${ }^{-1}$ are reached at LS 1. Peaks in PARs can be seen at LS 2.1 and 2.2 (2009-2011, ca. 3400 and ca. 1000 pollen grains $/ \mathrm{cm}^{2}$ year ${ }^{-1}$, respectively) as well as at LS 5.1 and 5.3 (2009-2010, ca. 1200 pollen grains $/ \mathrm{cm}^{2}$ year $^{-1}$ and 2011-2012, ca. 2000 pollen grains $/ \mathrm{cm}^{2}$ year $\left.{ }^{-1}\right)$. Weinmannia has PAR peaks at LS 1.1 (2009-2010, 1100 pollen grains/cm² year ${ }^{1}$ ), MS 1.1 and MS 1.3 (2009-2010, ca. 2300 pollen grains $/ \mathrm{cm}^{2}$ year $^{-1}$ and 2011-2012, ca. 1200 pollen grains $/ \mathrm{cm}^{2}$ year ${ }^{-1}$ ), US 1.1 and US 1.3 (2009-2010, ca. 2900 pollen grains $/ \mathrm{cm}^{2}$ year $^{-1}$ and 2011-2012, ca. 6000 pollen grains/cm² year $\left.{ }^{-1}\right)$, US 2.1 (2009-2010, ca. 1200 pollen grains/cm ${ }^{2}$ year ${ }^{1}$ ), US 3.3 (2011-2012, ca. 4100 pollen grains $/ \mathrm{cm}^{2}$ year $^{-1}$ ), and US 6.3 (2011-2012, ca. 3000 pollen grains $/ \mathrm{cm}^{2}$ year ${ }^{-1}$ ). Hedyosmum reaches PARs of up to 5800 pollen grains $/ \mathrm{cm}^{2}$ year ${ }^{-1}$ in US 3.2 , and is present in almost all plots with PARs of $>200$ pollen grains $/ \mathrm{cm}^{2}$ year ${ }^{-1}$. Hedyosmum shows PARs of $>1000$ pollen grains $/ \mathrm{cm}^{2}$ year ${ }^{-1}$ in the samples of LS 1 (ca. $1600-2400$ pollen grains $/ \mathrm{cm}^{2}$ year ${ }^{-1}$ ), LS 3 (ca. 1500 pollen grains $/ \mathrm{cm}^{2}$ year ${ }^{-1}$ ), LS $5.3\left(2011-2012\right.$, ca. 1100 pollen grains $/ \mathrm{cm}^{2}$ year $^{-1}$ ), MS 2.3 (2011-2012, ca. 3800 pollen grains $/ \mathrm{cm}^{2}$ year ${ }^{-1}$ ), MS 3.2 and 3.3 (2010-2011, ca. 2400 pollen grains $/ \mathrm{cm}^{2}$ year ${ }^{-1}$ and 2011-2012, ca. 1200 pollen grains $/ \mathrm{cm}^{2}$ year ${ }^{-1}$ ), MS 5.2 and 5.3 (2010-2011, ca. 2000 pollen grains $/ \mathrm{cm}^{2}$ year ${ }^{-1}$ and 2011-2012, ca. 2300 pollen grains $/ \mathrm{cm}^{2}$ year ${ }^{-1}$ ), MS 6.2 and 6.3 (2010-2011, ca. 2200 pollen grains $/ \mathrm{cm}^{2}$ year ${ }^{-1}$, and 2011-2012, ca. 1500 pollen grains $/ \mathrm{cm}^{2}$ year ${ }^{-1}$ ), US 1.2 and 1.3 (2010-2011, ca. 1600 pollen grains/cm² year ${ }^{-1}$, and 2011-2012, ca. 1200 pollen grains $/ \mathrm{cm}^{2}$ year $\left.{ }^{-1}\right)$, as well as in the samples of US 2.2 (2010-2011, ca. 1100 pollen grains $/ \mathrm{cm}^{2}$ year $\left.{ }^{-1}\right)$ and US $3\left(2400-5000\right.$ pollen grains $/ \mathrm{cm}^{2}$ year $\left.{ }^{-1}\right)$. Hieronyma is slightly less abundant, with PARs of $>1000$ pollen grains $/ \mathrm{cm}^{2}$ year ${ }^{-1}$ only being present at LS 3.3 (ca. 2800 pollen grains $/ \mathrm{cm}^{2}$ year ${ }^{-1}$ ), MS 2.3 (2011-2012, ca. 1400 pollen grains $/ \mathrm{cm}^{2}$ year $\left.{ }^{-1}\right)$, US 1.2 and 1.3 (2010-2011, ca. 1800 pollen grains/cm² year ${ }^{-1}$ and 2011-2012, ca. 1500 pollen grains/cm $\mathrm{cm}^{2}$ year ${ }^{-1}$ ), US 2.2 (2010-2011, ca. 2000 pollen grains/ $\mathrm{cm}^{2}$ year ${ }^{-1}$ ), and US 6.2 (2010-2011, ca. 2200 pollen grains $/ \mathrm{cm}^{2}$ year $\left.{ }^{-1}\right)$. The average PAR for selected pollen taxa for each slope position and year with 95\% confidence intervals is shown in Figure 8. The PARs of most taxa remain similar over the years, with only slight changes. Moraceae/Urticaceae show maxima in PARs at MS for 2009-2011 compared to 2011-2012 and at LS 2009-2010. Melastomataceae/Combretaceae have no pronounced peaks. Hedyosmum has lower PARs in 2009-2010 at all three slope positions. PARs of Piperaceae are homogenous throughout all years and sites, with slightly lower values for LS 20102011. Weinmannia shows high variations in PARs, with lowest values occurring in 2010-2011 at all 

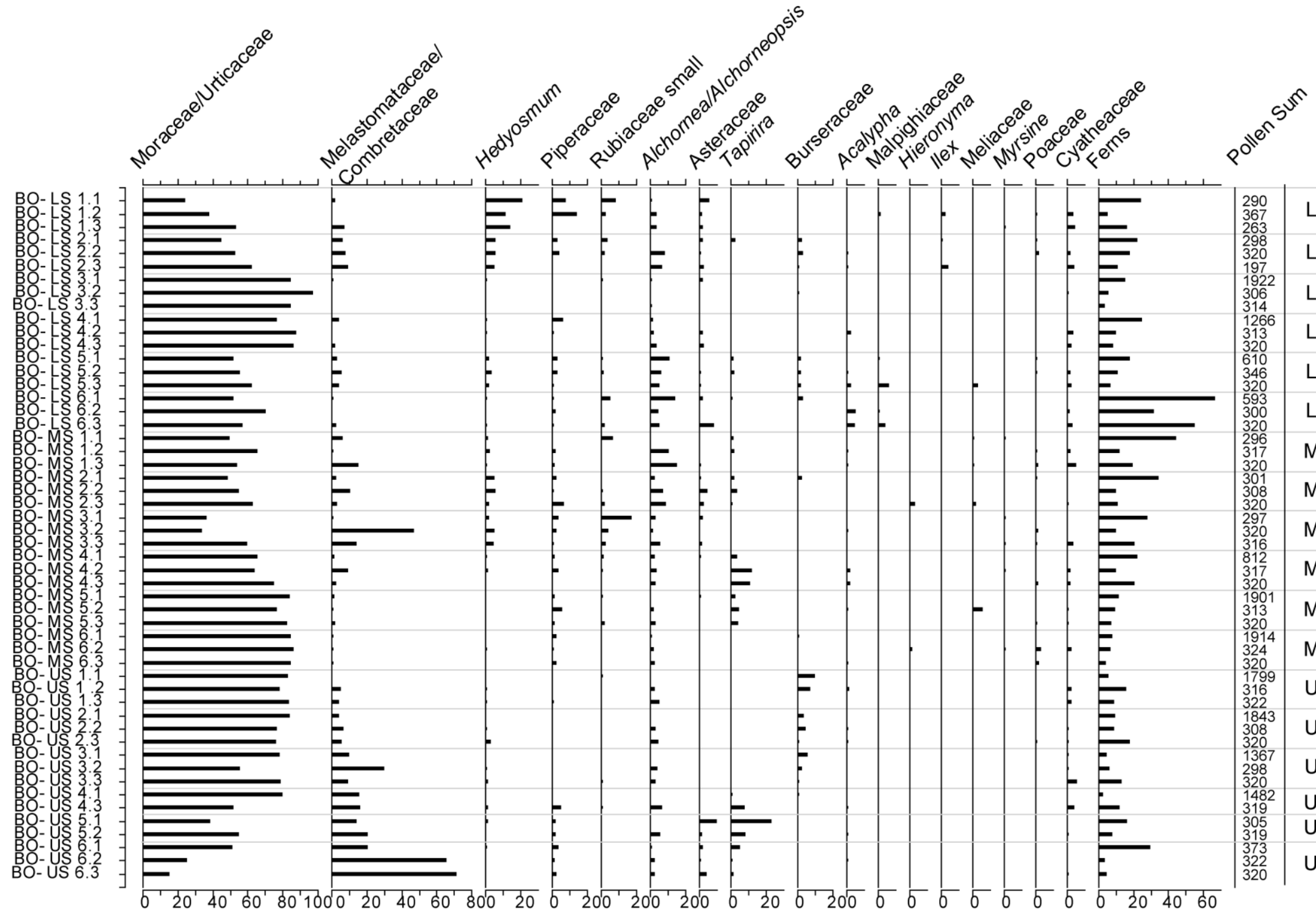

\begin{tabular}{|l|}
\hline LS 1 \\
\hline LS 2 \\
\hline LS 3 \\
\hline LS 4 \\
\hline LS 5 \\
\hline LS 6 \\
\hline MS 1 \\
\hline MS 2 \\
\hline MS 3 \\
\hline MS 4 \\
\hline MS 5 \\
\hline MS 6 \\
\hline US 1 \\
\hline US 2 \\
\hline US 3 \\
\hline US 4 \\
\hline US 5 \\
\hline US 6
\end{tabular}

Figure 16 Percentage digram of characteristic pollen taxa from the PMF at Bombuscaro. BO - Bombuscaro, LS - Lower slope, MS - Mid-slope, US - Upper slope, the numbers behind the slope number represent the period in which the pollen trap collected pollen: $1-2009-2010,2-2010-2011,3-2011-2012$. The asterisk marks the samples where a different trap was counted for the same plot. 

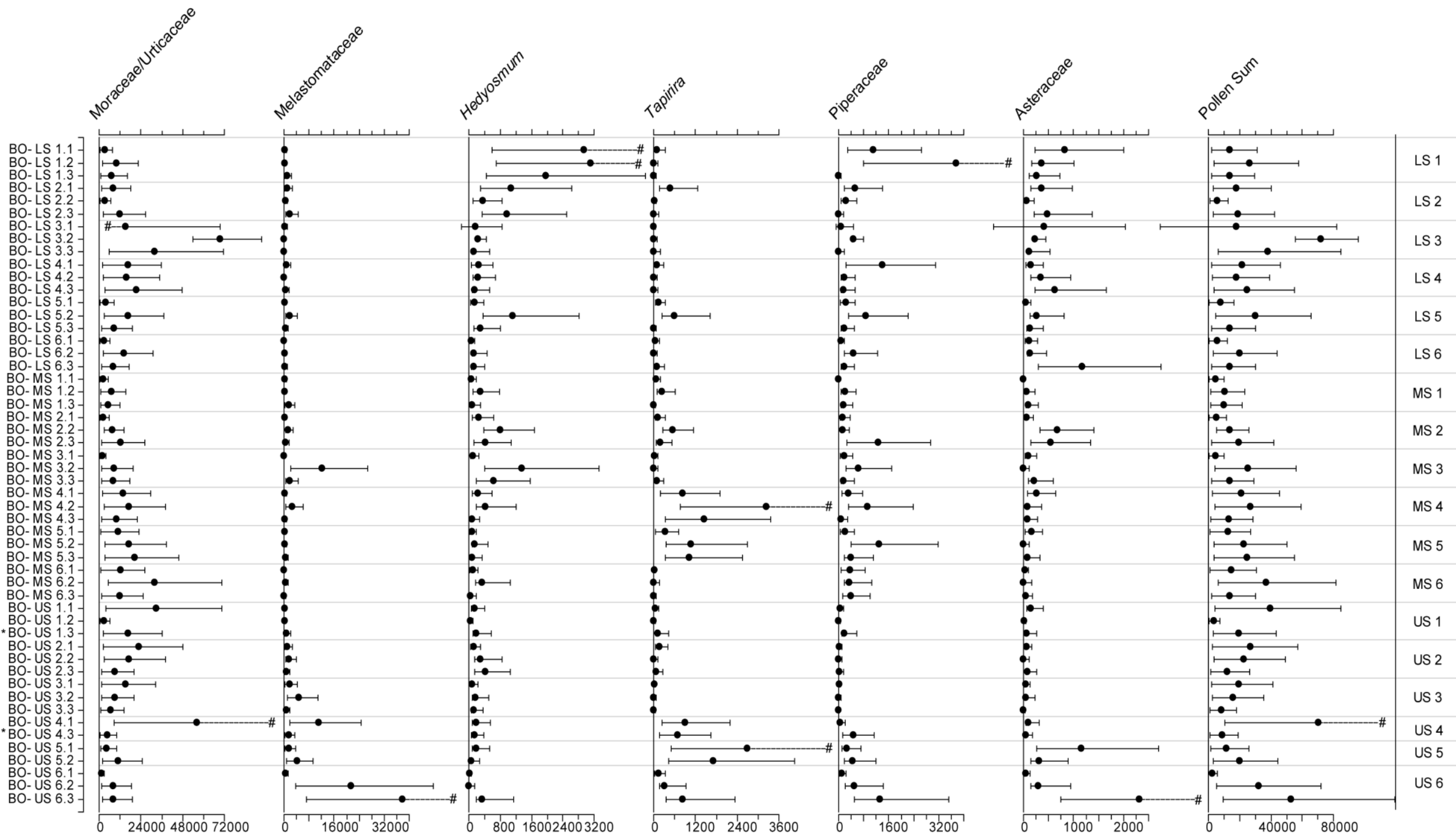

Figure 17 Pollen accumulation rates for characteristic taxa of the PMF at Bombuscaro. Error bars represent the counting errors of pollen grains and Lycopodium marker spores based on Mosiman (1965). BO - Bombuscaro, LS - Lower slope, MS - Mid-slope, US - Upper slope, the numbers behind the slope number represent the period in which the pollen trap collected pollen: 1 2009-2010, 2 - 2010-2011, 3-2011-2012. The asterisk marks the samples where a different trap was counted for the same plot. The number sign marks high errorbars that are not displayed in their totality. 


\section{Moraceae/Urticaceae}

\section{Tapirira type}

\section{Piperaceae}

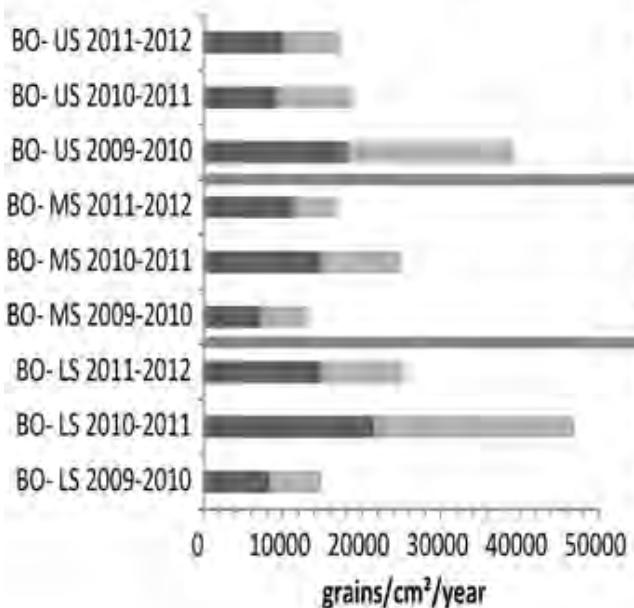

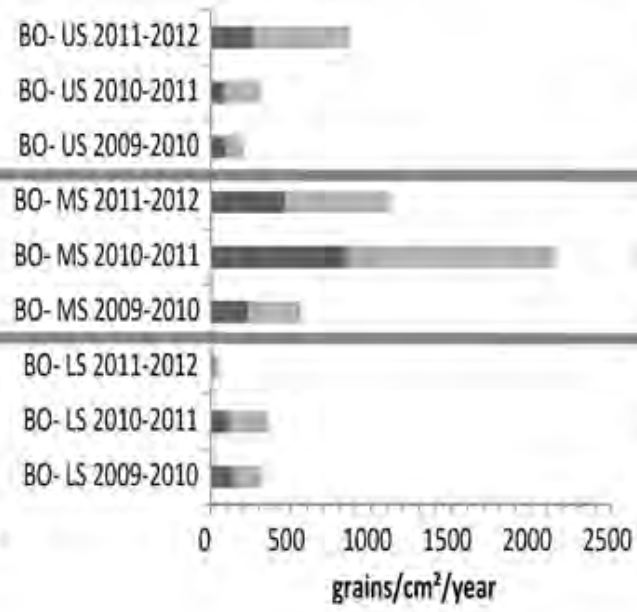

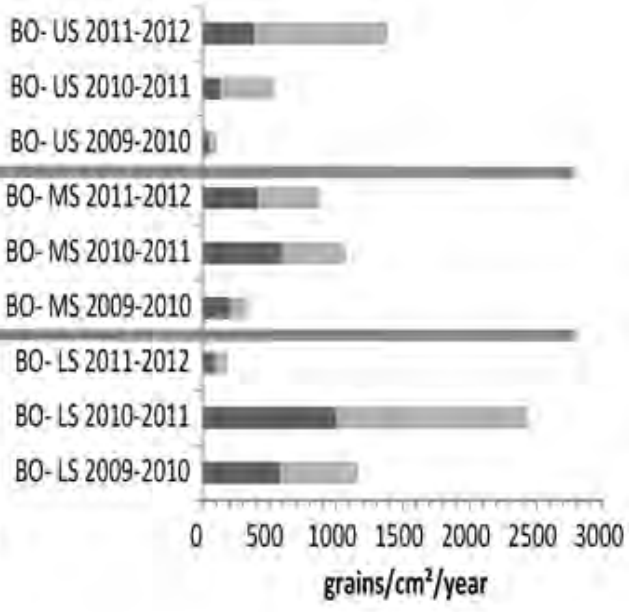

\section{Melastomataceae/Combretaceae}

Hedyosmum

\section{Asteraceae}

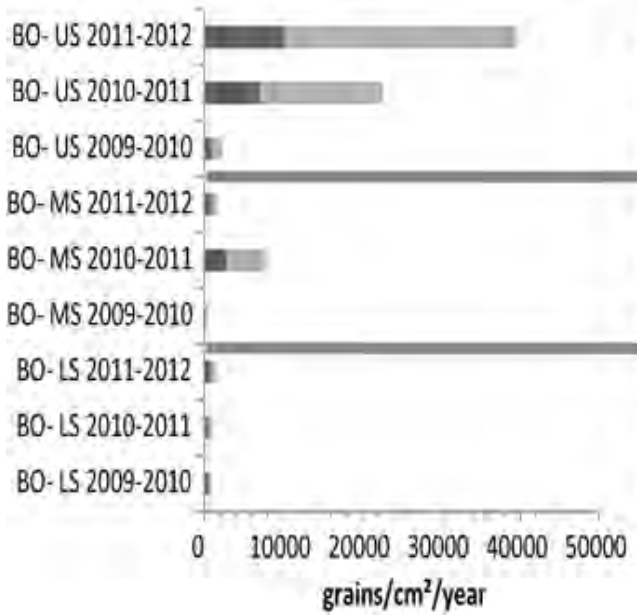

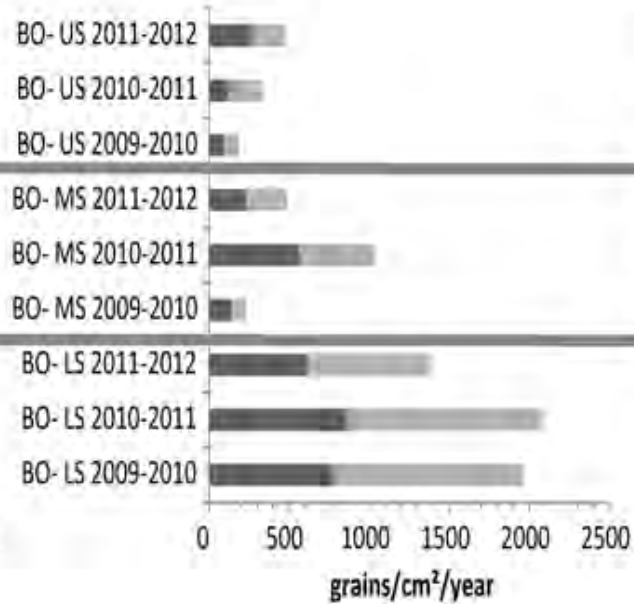
BO- US 2011-2012 BO-US2010-2011 = BO-US 2009-2010 $\mathrm{n}$

BO- MS 2011-2012 를
BO-MS 2010-2011 BO-MS 2009-2010 :

BO-LS 2011-2012 ED:

BO- LS 2010-2011 $=$
BO- $152009-2010$

Figure 18 Average pollen accumulation rates (grains $\mathrm{cm}^{-2} \mathrm{yr}^{-1}$ ) for selected taxa for the PMF at Bombuscaro with $95 \%$ confidence intervals (marked in grey). Data is given for each slope and year. LS - lower slope, MS- Mid-slope, US - Upper slope. 
slope positions. Hieronyma has high values at US in 2010-2011 and relatively low values at MS in 2009-2010.

\subsubsection{Premontane Forest - Bombuscaro}

\section{Percentages}

A percentage diagram for selected pollen taxa of the premontane forest in Bombuscaro is shown in Figure 9. Here, proportions of Moraceae/Urticaceae reach by far the highest values in most of the samples, which range between ca. 15 and $90 \%$. Values of around or over $80 \%$ are reached in the samples of LS 3, LS 4, MS 5, MS 6, US 1, US 2, US 3.1 and 3.3 (2009-2010 and 2011-2012), as well as US 4.1 (2009-2010). The second most abundant pollen taxon is Melastomataceae/Combretaceae. This pollen taxon dominates the samples where pollen of Moraceae/Urticaceae are not present with high proportions, such as MS 3.2 (2010-2011, 47\%) and US 6.2 and 6.3 (2010-2012, with 66 and 71\%, respectively). Pollen of Hedyosmum reaches proportions of between 12 and $21 \%$ in LS 1 and ranges within 0.3 and $6 \%$ in the other samples. All other pollen taxa show low proportions of $<5 \%$ in most of the samples, with small peaks of $5-15 \%$ at single sites. For pollen of Piperaceae, highest proportions are reached at LS 1.1 (2009-2010, 8\%), LS 1.2 (2010-2011, 14\%), LS 4.1(2009-2010) and MS 2.3 (2011-2012) both 7\%, and MS 5.2 (2010-2011, 6\%). Pollen of Rubiaceae (small type) have highest percentage values at LS 1.1 (20092010, 8\%) and MS 3.1 (17.5\%, 2009-2010).Pollen of Alchornea/Alchorneopsis type has values of between 0 and 15\%, with values of over 5\% in samples of LS 2.2 and 2.3 (2010-2011, 8\% and 2011-2012, 7\%), LS 5.3 (11\%, 2011-2012), MS 1.2 and 1.3 (2010-2011, 10\% and 2011-2012, 15\%), as well as MS 2.2 and 2.3 (2010-2011, 8\% and 2011-2012, 9\%), MS 3.3 (2011-2012, 6\%), US 1.3 (2011-2012, 5\%) and US 4.3 (2011-2012, 7\%). Pollen of Asteraceae shows percentages over 5 in the samples of LS 1.1 (2009-2010, 6\%), LS 6.3 (2011-2012, 8\%) and US 5.1 (2009-2010, 10\%). Tapirira has pollen proportions with values of $>5 \%$ at MS 4.2 and 4.3 (2010-2011, 12\% and 20112012, 11\%), US 4.3 (2011-2012, 8\%), US 5.1 and 5.2 (2009-2010, 23\% and 2010-2011, 9\%) as well as at US 6.1 (2009-2010,5\%). Pollen of Burseraceae is more abundant in samples of US 1, 2 and 3 , with highest values of 10\% at US 1.1 (2009-2010), and 6\% at US 3.1 (2009-2010). Acalypha, Malpighiaceae, Hieronyma, Ilex, Meliaceae, Myrsine and Poaceae are relatively rare pollen taxa with maxima of around or under $5 \%$. Spores of Cyatheaceae range around $0-5 \%$. Spores of other ferns peak at LS 6 and MS 1-4, with highest values of 66\% at LS 6.3 (2011-2012). 


\section{Pollen accumulation rates (PARs)}

Figure 10 shows selected taxa with their PARs and calculated errors. PARs throughout the samples of the PMF are high, with values ranging from 2700 pollen grains $/ \mathrm{cm}^{2}$ year $^{-1}$ (US 6.1, 2009-2010) to 72,000 pollen grains $/ \mathrm{cm}^{2}$ year $^{-1}$ (LS 3.2, 2010-2011). The average total pollen accumulation is 20,000 pollen grains $/ \mathrm{cm}^{2}$ year ${ }^{-1}$. Moraceae/Urticaceae have high PARs, ranging from 1400 pollen grains $/ \mathrm{cm}^{2}$ year ${ }^{-1}$ (US 6.1, 2009-2010) to 70,000 pollen grains $/ \mathrm{cm}^{2}$ year ${ }^{-1}$ (LS 3.2, 2010-2011). High peaks are found at LS 3.2, MS 6.2 (3200 pollen grains $/ \mathrm{cm}^{2}$ year $^{-1}, 2010-2011$ ), US 1.1 (2009-2010, 33,000 pollen grains $/ \mathrm{cm}^{2}$ year ${ }^{-1}$ ) and US 4.1 (2009-2010, 56,000 pollen grains $/ \mathrm{cm}^{2}$ year ${ }^{-1}$ ). Melastomataceae have PARs ranging from 0 to ca. 38,000 pollen grains $/ \mathrm{cm}^{2}$ year ${ }^{-1}$. Whereas most of the samples have PARs of between 0 and 2000 pollen grains $/ \mathrm{cm}^{2}$ year ${ }^{-1}$, higher peaks are present at MS 3.2 (2010-2011, ca. 12,000 pollen grains/cm² year $\left.{ }^{-1}\right)$, US 4.1 (2009-2010, ca. 11,000 pollen grains $/ \mathrm{cm}^{2}$ year ${ }^{-1}$ ), as well as at US 6.2 and 6.3 (2010-2011, ca. 21,000 pollen grains $/ \mathrm{cm}^{2}$ year $^{-1}$ and 2011-2012, ca. 38,000 pollen grains $/ \mathrm{cm}^{2}$ year $\left.^{-1}\right)$. Pollen of Hedyosmum and Tapirira is present in most of the samples with PARs ranging from 20-1000 pollen grains $/ \mathrm{cm}^{2}$ year ${ }^{-1}$. Higher rates for Hedyosmum are reached in the samples at LS 1 (ca. 2000-3100 pollen grains/ $\mathrm{cm}^{2}$ year ${ }^{-1}$ ), LS 2.1 and 2.3 (2009-2010, ca. 1100 pollen grains $/ \mathrm{cm}^{2}$ year ${ }^{-1}$ and 2011-2012, ca. 2000 pollen grains $/ \mathrm{cm}^{2}$ year $^{-1}$ ), LS 5.2 (2010-2011, ca. 11,000 pollen grains/cm² year $^{-1}$ ) and MS 3.2 (2010-2011, ca. 1400 pollen grains $/ \mathrm{cm}^{2}$ year $\left.{ }^{-1}\right)$. Pollen of Tapirira has its highest abundances in the samples of MS 4.2 and 4.3 (2010-2011, ca. 3200 pollen grains $/ \mathrm{cm}^{2}$ year $^{-1}$ and 2011-2012, ca. 1500 pollen grains $/ \mathrm{cm}^{2}$ year $\left.{ }^{-1}\right)$, as well as MS 5.2 and 5.3 (2010-2011, ca. 1100 pollen grains $/ \mathrm{cm}^{2}$ year ${ }^{-1}$ and 2011-2012, ca. 1000 pollen grains $/ \mathrm{cm}^{2}$ year $^{-1}$ ) and US 5.1 and 5.2 (2009-2010, ca. 2700 pollen grains $/ \mathrm{cm}^{2}$ year ${ }^{-1}$ and 2010-2011, ca. 1700 pollen grains $/ \mathrm{cm}^{2}$ year $\left.{ }^{-1}\right)$. Pollen of Piperaceae is present in all samples and obtains highest values in the samples of LS 1.1 and LS 1.2 (2009-2010, ca. 1100 pollen grains $/ \mathrm{cm}^{2}$ year ${ }^{-1}$ and 2010-2011, ca. 3800 pollen grains $/ \mathrm{cm}^{2}$ year ${ }^{-1}$ ), LS 4.1 (20092010, ca. 1400 pollen grains/cm² year ${ }^{-1}$ ), MS 2.3 (2010-2011, ca. 1300 pollen grains $/ \mathrm{cm}^{2}$ year ${ }^{-1}$ ), MS 5.2 (2010-2011, ca. 1300 pollen grains/cm² year $\left.^{-1}\right)$ and US 6.3 (2011-2012, ca. 1300 pollen grains $/ \mathrm{cm}^{2}$ year ${ }^{-1}$ ). Pollen of Asteraceae is especially abundant in the samples of LS 6.3 (20112012, ca. 1200 pollen grains $/ \mathrm{cm}^{2}$ year $\left.{ }^{-1}\right)$, US 5.1 (2009-2010, ca. 1200 pollen grains/ $\mathrm{cm}^{2}$ year $\left.^{-1}\right)$ and US 6.3 (2011-2012, ca. 2300 pollen grains $/ \mathrm{cm}^{2}$ year $\left.{ }^{-1}\right)$. The comparison of average PARs per slope position and year shows no high peaks for any of the taxa (Fig. 11). Slight increases in abundance can be seen for Moraceae/Urticaceae at US in 2009-1010, as well as at LS and MS in 2010-2011. Melastomataceae have increased PARs compared to the other years at the same slope position in 2010-2011 and 2011-2012 compared to 2009-2010 and at MS 2010-2011. Tapirira has the tendency to higher PARs in 2010-2011 at MS. Hedyosmum has higher values at MS 2010-2011 but 
constant PARs in the other years. Piperaceae have comparatively lower PARs at LS in 2011-2012 and in 2009-2010 at the other slope types. Asteraceae show higher PARs at US 2011-2012.

\subsection{Discussion}

\subsubsection{What are the pollen accumulation rates for characterising pollen taxa of the north-central} Andean forests?

Table1 shows the PARs for the most characterising taxa in the studied forest types. The data clearly shows that PARs are a good tool to not only estimate the average pollen productivity of a given forest type but also distinguish different forest types by their pollen spectra and PARs. The total PAR is highest in the LMF and lowest in the UMF, but variations within one forest types are considerable, as has been observed for other tropical forests (Bush and Rivera 1998, Niemann et al. 2010). Even though most pollen taxa can be found in all study regions, PARs vary considerably between them. Myrsine, Weinmannia, Hieronyma and Clusia type may occur in PMF as well as in LMF, but PAR values are much higher in LMF. The same is valid for Alnus, Myrsine and Weinmannia for UMF in comparison with LMF. Similar proportions of Melastomataceae, Hedyosmum and Weinmannia have been reported for a transect study of pollen traps from 1920 to $3185 \mathrm{~m}$ a.s.l. in the San Francisco region (Niemann et al. 2010). Whereas a skilled palynologist can determine the altitude of a given pollen sample with an accuracy of about $350 \mathrm{~m}$ elevation (Weng et al. 2004), it is, due to the Fagerlind effect, difficult to quantify the results accurately using percentage values. Our data show that some taxa, that have been grouped into certain vegetation zones before (e.g. Melastomataceae/Combretaceae as subpáramo/montane forest taxon, as in Niemann and Behling (2008, 2009a, 2009b), Niemann et al. (2009), Brunschön and Behling (2009, 2010), Jantz and Behling (2011)) do not show distinct elevation patterns neither concerning percentage data nor PARs but instead occur to a similar extent in all forest types. The same is true for other abundant pollen taxa (i.e. Asteraceae for PMF/LMF/UMF, Alchornea/Alchorneopsis for PMF/LMF, Clusia type for LMF/UMF) and highlights the fact that the creation of "vegetation zones" is often biased. Even though the zonation is carried out using the most proximate vegetation type as a reference, it can lead to misleading interpretations. It should be kept in mind that an accurate vegetation reconstruction should not only consider abundances of dominant pollen taxa but also pollen composition. This is supported by findings of Weng et al. (2004) who discovered that in very species-rich regions, such as the Andes or Amazon region, presence-absence data of moss polsters, which are often biased by a high amount of entomophilous taxa due to their placement under the canopy, can be more comparable with fossil lake records than percentage data. Gosling et al. (2009) suggest the "assemblage-approach", 
a combination of presence/absence and abundance data, to be best for the characterisation of moist evergreen tropical forests, seasonally dry semi-deciduous tropical forests and savannahs. We find the same to be valid for the PMF, LMF and UMF of the northern-central Andes region, as abundances of important taxa can vary greatly depending on the particular site (e.g. Moraceae/Urticaceae $20-30 \%$ at BO-LS 1 compared to ca. $80-90 \%$ at BO- MS 6) or the year sampled.

\subsubsection{Do any of the characteristic pollen taxa show strong inter-annual variations in their pollen accumulation rates (PARs)?}

The pollen signals of most of the characterising taxa in the modern pollen rain of PMF, LMF and UMF in South Ecuador do not show distinct high inter-annual variations. Maxima in PARs, if present, vary across the years for different sites and do not show any uniform pattern of synchronisation. Similar observations have been made by Gosling et al. (2005) for a moist terra firme forest in Amazonian Bolivia. However, they discovered a decrease in the total PAR during a dry year (Gosling et al. 2005). The inhomogeneous patterns of PARs in this study may have several reasons. The fact that sometimes, few to many species belong to one pollen taxon, make generalisations difficult, as each of the species may have a different phenological pattern which is caused by different environmental response mechanisms. Appendix 2 shows an overview of the tree species with $\mathrm{BDH}>5 \mathrm{~cm}$ recorded at the study sites. Especially for Moraceae/Urticaceae, Melastomataceae/Combretaceae, Piperaceae and Asteraceae, several species of smaller trees, shrubs, and/or lianas may add to the number of pollen producing species for these taxa. However, few pollen taxa, such as Tapirira (T. guianensis) in PMF, Hieronyma (H. macrocarpa) in LMF and Myrica (M. pubescens), Hedyosmum (H. purpurascens) and Myrsine (M. andina) in UMF are represented only by one species at the study site. All of these species seem to flower to an equal extent every year, showing only slight variations, which are not consistent across the slope positions during the years. Studies about tree phenology have shown that climatic factors, especially precipitation, radiation and photoperiodic control can induce flowering in tropical tree species (Günter et al. 2008). Bendix et al. (2006) have shown for 10 tree species occurring in the San Francisco area, that three groups of flowering periodicity could be distinguished: One starts flowering at the onset of the drier period (Tabebuia, Piptocoma, Purdiaea), one just before (Isertia, Clethra) and the last one with the start of the rainy season (Vismia, Heliocarpus, Graffenrieda). As our data have a temporal resolution of one year, small scale seasonal variations could not be observed. Bendix et al. (2006) support the hypothesis that shading of clouds and an increase in the proportions of diffuse radiation causing changes in spectral composition is responsible for the synchronisation of phenology within one tree species. However, they mention, 
that, even though most species assessed flower once a year, irregular flowering events or lack of flowering can occur due to irregular meteorological events following unknown cyclic climate phenomena that could not fully be resolved. This observation is supported by the study of Cueva Ortiz et al. (2006) in the same area and most probably applies for our data from the same study region. Long-term studies for at least seven years are necessary to cover the large inter-annual variability, as both the current and the previous year's climate can influence pollen rain composition (Haselhorst et al. 2013). For example, an ENSO event did not occur during our sampling period, which could change the regular flowering pattern. Also, Sakai (2001) reports for a neotropical humid forest in Costa Rica, that the majority of tree taxa $(55 \%)$ follow a subannual flowering pattern with irregular periods of flowering throughout the year, whereas only $29 \%$ of the trees flower once a year. As high degrees of intra- and sometimes even inter-specific flowering synchronisation was observed by all studied tree species from the region of South Ecuador (Cueva Ortiz et al. 2006, Bendix et al. 2006, Günter et al. 2008), with the exception of Graffenrieda emarginata (Melastomataceae) the question remains why this synchronisation is not visible to a similar extent in our study. Instead, our data show different peaks for all plots within every study site and summing of the data (Figs. 4, 8 and 11) leads to high errors. Also, Cueva Ortiz et al. (2006) recorded a synchronous irregular absence of flowers within the flowering period, which is supposedly due to exceptional weather phenomena during just before the flowering period. This fact may explain some of the peaks, but not their irregularity within one slope situation. Several reasons may be responsible for this discrepancy between plant and pollen data. As a variety of different micro-sites was chosen by the authors, we can exclude a low spatial coverage, which would have restricted plant and/or pollen data to a very narrow local range. However, different degrees of strength of the individual tree's flowering, due to biotic or abiotic stress factors, such as the intraspecific and interspecific competition for pollinators or seed dispersers (Sakai 2001) could be one possible reason for variability in phenology patterns and thus pollen accumulation rates within one study area. For example, Opler et al. (1980) showed highly individual responses in the phenological patterns of treelet and shrub species in forests of Costa Rica. A discrepancy of pollen and plant data can also relate to anomalies in the pollen data. As stated before, calculated errors on PARs are relatively high and can explain large irregularities in the data. In turn, they could also have evened out changes between the years. However, other factors related to pollen transport could also explain part of the bias. Also, the fact that pollen may get trapped in the leaves of the canopy layer (Andersen, 1974) before falling down eventually affects the time-component of pollen deposition in the pollen trap. Tauber (1967) gives a good overview of the processes involved in pollen dispersion. He states that not only convection currents, but also other factors, such as varying wind velocities, intra-annual changes in 
atmospheric turbulences, different grain fall speeds for each taxon, as well as the influence of the physical vegetation structure are important when looking at the distribution of pollen grains (Tauber 1967). However, an analysis of these factors would require a carefully planned local assessment involving detailed microclimatic measurements and a range of physical distribution models which is very difficult to accomplish for a heterogeneous tropical forest. Nevertheless, they should be kept in mind when working with pollen data for ecological purposes.

\subsubsection{How strong is the influence of the pollen trap distribution on the pollen spectra?}

Our results indicate that the pollen spectra of many of the traps are influenced to a high amount by pollen rain of adjacent trees. Appendix 2 shows an overview of the two nearest tree species to each trap. However, other species close-by that have a greater pollen production may influence the pollen spectra. The recorded data from two traps on one site at Cajanuma (Fig. 4) indicate that very local pollen accumulation seems to be an important factor that can not only explain high maxima of single species in the pollen data but also the total PAR of a specific sample. Haselhorst et al. (2013) show that the presence of trees adjacent to pollen traps lead to high levels of overrepresentation of that taxon in the samples. They state that beyond a distance of $>5 \mathrm{~m}$, these differences tend to even out. In our data, it is evident, that in many cases, the spatial component seems to have a higher influence on the pollen spectra than the temporal component. For some taxa, e.g. Weinmannia, Melastomataceae/Combretaceae, as well as partly Piperaceae and Tapirira, patterns seem rather variable and more data have to be collected to make general patterns visible. Generally the overall variability of the data suggests that in tropical environments, an amount of at least 10 pollen traps is a sensible database to capture the full variability of the pollen spectra which is needed e.g. for paleoecological calibration. Besides the local component in the modern pollen rain spectra, the long-distance component seems to be of equal importance. Andersen (1974) stated that wind speeds and directions play a big role in pollen transport mechanisms and that pollen grains produced in the upper layer of the canopy will many times be transported over larger distances above the canopy. Bush and Rivera (1998) showed that in Panama, $68 \%$ of the pollen is transported from a distance of over $20 \mathrm{~m}$ and $22 \%$ of over $40 \mathrm{~m}$. Similar observations, which showed that $25-90 \%$ of the pollen derives from $>20 \mathrm{~m}$ distance have been made by other authors for temperate forests (Jackson and Wong 1994, Jackson and Kearsley 1998). In a different study concerning the modern pollen rain patterns in relationship to the vegetation on the same study sites that are used in this paper, we discovered high percentages of external pollen taxa in most of the sites, which indicated an up-drift of taxa from lower sites at the UMF and a down-drift from higher areas at LMF and PMF (Jantz et al. 2013). This is, because the Cajanuma area (UMF) is dominated by strong south-easterly trade 
winds, whereas San Francisco (LMF) is controlled by a mountain-valley wind system with up-valley winds during the day and down-valley winds at night and different seasonal patterns. For Bombuscaro, an adynamic along-valley wind system is assumed (Emck 2007). However, other studies showed that, whereas up-slope movements lead to an over-representation of taxa from lower altitudes especially in the UMF, down-slope movements increase the diversity of lower sites but usually do not cause high over-representation of taxa from higher altitudes (Jantz et al., in preparation, Bush 2000, Niemann et al. 2010). This is visible in the data of this study, as Moraceae/Urticaceae belong to the taxa with higher PARs even in the UMF, where no bigger trees of these families are present and only small trees, shrubs and herbs could account for a local pollen production. This long-distance transport depends largely on microclimatic factors and wind patterns throughout the year and will thus not be the same for every site or year. Therefore, irregular patterns in pollen spectra could be generated. We think that further investigations on phenological patterns as well as on pollen transport patterns, i.e. through a more frequent exchange of traps to see seasonal flowering patterns and with installing traps at different stand heights and across a larger transect in the region could help to further explore the underlying mechanisms.

\subsection{Conclusions}

The three year modern pollen rain study across the three different forest types of premontane forest, lower montane forest and upper montane forest characterise the three forest types by their pollen spectra and PARs. The analysis confirms that PARs can give broad insights into pollen production of a given vegetation type. It is important for palynologists to also calculate errors on PARs, as they give valuable information about data reliability.

As similar PARs occur throughout all analysed Andean forest types, paleoecological vegetation zones using frequent pollen taxa, such as Melastomataceae/Combretaceae, Weinmannia and Myrsine are not always reliable. Instead, more emphasis should be put to the "assemblageapproach" which should be used in combination with abundance thresholds of characteristic taxa, as suggested by Gosling et al. (2009).

The characteristic pollen taxa for the three forest types do not show distinct synchronous interannual variations in their PARs but respond rather individually throughout the years analysed. This can have several possible reasons: 1 . Individual taxa responses vary due to environmental stress factors that differ for every site, 2. Factors that can influence pollen dispersal, such as wind velocities, intra-annual changes in atmospheric turbulences, different grain fall speeds, as well as the physical vegetation structure, vary for each site and lead to a blurred pollen signal in the traps. 
The local distribution of the pollen traps has a strong influence on the pollen spectra. Even though long-distance transport is known to be an important component in pollen traps, pollen signals can vary strongly between traps that have been distributed only a few metres apart from each other. Tropical palynologists should thus not rely on single traps for a paleoecological calibration, but rather analyse several traps to capture an appropriate degree of variability within the dataset.

\subsection{Acknowledgements}

The authors appreciate the help of Michael Burstert, Nixon Cumbicus, Jaime Peña and Andrea and Stéphany Villota during fieldwork. The local team of the DFG RU 816 at the Reserva Biológica San Francisco is thanked for logistic support. We also thank Thomas Giesecke for valuable scientific discussions on the topic. This research has been funded by the DFG project FOR 816 (Grants BE2116/8-2 and HO3296/2-2).

\subsection{References}

Andersen, S. 1974. Wind Conditions and Pollen Deposition in a Mixed Deciduous Forest. Grana 14:64-77.

Beck, E., F. Makeschin, F. Haubrich, M. Richter, J. Bendix, and C. Valarezo. 2008. The Ecosystem (Reserva Biológica San Francisco). Pages 1-13 in E. Beck, J. Bendix, I. Kottke, F. Makeschin, and R. Mosandl, editors. Gradients in a tropical mountain ecosystem of Ecuador. Springer, Berlin.

Behling, H., M. Cohen, and R. Lara. 2001. Studies on Holocene mangrove ecosystem dynamics of the Bragança Peninsula in north-eastern Pará, Brazil. Palaeogeography, Palaeoclimatology, Palaeoecology 167:225-242.

Behling, H., R. Negrelle, and P. Colinvaux. 1997. Modern pollen rain data from the tropical Atlantic rain forest, Reserva Volta Velha, South Brazil. Review of Palaeobotany and Palynology 97:287-299.

Bendix, J., J. Homeier, E. Cueva Ortiz, P. Emck, S.-W. Breckle, M. Richter, and E. Beck. 2006. Seasonality of weather and tree phenology in a tropical evergreen mountain rain forest. International Journal of Biometeorology 50:370-384.

Bendix, J., R. Rollenbeck, M. Richter, P. Fabian, and P. Emck. 2008. Climate. Pages 63-73 in E. Beck, J. Bendix, I. Kottke, F. Makeschin, and R. Mosandl, editors. Gradients in a tropical mountain ecosystem of Ecuador. Springer, Berlin.

Bennett, K. D. 1994. Confidence intervals for age estimates and deposition times in lateQuaternary sediment sequences. The Holocene 4:337-348.

Brunschön, C., and H. Behling. 2009. Late Quaternary vegetation, fire and climate history reconstructed from two cores at Cerro Toledo, Podocarpus National Park, southeastern Ecuadorian Andes. Quaternary Research 72:388-399.

Brunschön, C., and H. Behling. 2010. Reconstruction and visualization of upper forest line and vegetation changes in the Andean depression region of southeastern Ecuador since the last glacial maximum - A multi-site synthesis. Review of Palaeobotany and Palynology 163:139-152.

Burn, M., F. Mayle, and T. Killeen. 2010. Pollen-based differentiation of Amazonian rainforest communities and implications for lowland palaeoecology in tropical South America. Palaeogeography, Palaeoclimatology, Palaeoecology 295:1-18. 
Bush, M. B. 2000. Deriving Response Matrices from Central American Modern Pollen Rain. Quaternary Research 54:132-143.

Bush, M., and R. Rivera. 1998. Pollen dispersal and representation in a neotropical rain forest. Global Ecology and Biogeography 7:379-392.

Cueva Ortiz, E., J. Homeier, S.-W. Breckle, J. Bendix, P. Emck, M. Richter, and E. Beck. 2006. Seasonality in an evergreen tropical mountain rainforest in southern Ecuador. Ecotropica 12:69-85.

Davis, M. B. 1963. On the theory of pollen analysis. American Journal of Science 261:897-912.

Emck, P. 2007. A climatology of South Ecuador - With special focus on the Major Andean Ridge as Atlantic-Pacific Climate Divide. Dissertation, Universität Erlangen-Nürnberg.

Fagerlind, F. 1952. The real signification of pollen diagrams. Botaniska Notiser 1952:185-224.

Giesecke, T., W. van der Knaap, and F. Bittmann (Eds.). 2010. Towards quantitative palynology: using pollen accumulation rates and models of pollen dispersal. Vegetation History and Archaeobotany 19.

Gosling, W., F. Mayle, N. Tate, and T. Killeen. 2005. Modern pollen-rain characteristics of tall terra firme moist evergreen forest, southern Amazonia. Quaternary Research 64:284-297.

Gosling, W., F. Mayle, N. Tate, and T. Killeen. 2009. Differentiation between Neotropical rainforest, dry forest, and savannah ecosystems by their modern pollen spectra and implications for the fossil pollen record. Review of Palaeobotany and Palynology 153:7085.

Grimm, E. C. 1987. CONISS: A Fortran 77 program for stratigraphically constrained cluster analysis by the method of the incremental sum of squares. Computer and Geosciences:13-35.

Günter, S., B. Stimm, M. Cabrera, M. Diaz, M. Lojan, E. Ordoñez, M. Richter, and M. Weber. 2008. Tree phenology in montane forests of southern Ecuador can be explained by precipitation, radiation and photoperiodic control. Journal of Tropical Ecology 24.

Hansen, B., D. Rodbell, G. Seltzer, B. Leon, K. Young, and M. Abbott. 2003. Late-glacial and Holocene vegetational history from two sites in the western Cordillera of southwestern Ecuador. Palaeogeography, Palaeoclimatology, Palaeoecology 194:79-108.

Haselhorst, D., J. Moreno, and S. Punyasena. 2013. Variability within the 10-Year Pollen Rain of a Seasonal Neotropical Forest and Its Implications for Paleoenvironmental and Phenological Research. PLoS ONE 8:e53485.

Hicks, S., B. Ammann, M. Latalowa, H. Pardoe, and H. Tinsley. 1996. European Pollen Monitoring Programme. Project description and Guidelines. Oulu University Press.

Hicks, S., and H. Hyvärinen. 1999. Pollen influx values measured in different sedimentary environments and their palaeoecological implications. Grana 38:228-242.

Homeier, J., F. Werner, R. Gradstein, S.-W. Breckle, and M. Richter. 2008. Potential vegetation and floristic composition of Andean forests in South Ecuador, with a focus on the RBSF. Pages 87-100 in E. Beck, J. Bendix, I. Kottke, F. Makeschin, and R. Mosandl, editors. Gradients in a tropical mountain ecosystem of Ecuador. Springer-Verlag, Berlin-Heidelberg.

Jackson, S., and J. Kearsley. 1998. Quantitative representation of local forest composition in forest-floor pollen assemblages. Journal of Ecology 86:474-490.

Jackson, S., and A. Wong. 1994. Using forest patchiness to determine pollen source areas of closed-canopy pollen assemblages. Journal of Ecology 82:89-99.

Jantz, N., and H. Behling. 2011. A Holocene environmental record reflecting vegetation, climate, and fire variability at the Páramo of Quimsacocha, southwestern Ecuadorian Andes. Vegetation History and Archaeobotany 21:169-185.

Jones, H., F. Mayle, R. Pennington, and T. Killeen. 2011. Characterisation of Bolivian savanna ecosystems by their modern pollen rain and implications for fossil pollen records. Review of Palaeobotany and Palynology 164:223-237.

Juggins, S. 2003. C $C^{2}$ User Guide. Software for Ecological and Paleoecological Data Analysis and Visualisation. University of Newcastle, Newcastle upon Tyne, UK. 
Knaap, W., J. Leeuwen, H. Svitavská-Svobodová, I. Pidek, E. Kvavadze, M. Chichinadze, T. Giesecke, B. Kaszewski, F. Oberli, L. Kalnina, H. Pardoe, W. Tinner, and B. Ammann. 2010. Annual pollen traps reveal the complexity of climatic control on pollen productivity in Europe and the Caucasus. Vegetation History and Archaeobotany 19:285-307.

Maher, L. 1981. Statistics for microfossil concentration measurements employing samples spiked with marker grains. Review of Palaeobotany and Palynology 32:153-191.

Moser, G., D. Hertel, and C. Leuschner. 2007. Altitudinal Change in LAI and Stand Leaf Biomass in Tropical Montane Forests: a Transect Study in Ecuador and a Pan-Tropical Meta-Analysis. Ecosystems 10:924-935.

Mosiman, J. 1965. Handbook of Paleontological Techniques. Pages 636-673 in B. Kummel and D. Raup, editors. Statistical methods for the pollen analyst: multinominal and negative multinominal techniques. Freeman and Company, San Francisco.

Niemann, H., and H. Behling. 2008. Late Quaternary vegetation, climate and fire dynamics inferred from the El Tiro record in the southeastern Ecuadorian Andes. Journal of Quaternary Science 23:203-212.

Niemann, H., and H. Behling. 2009a. Late Pleistocene and Holocene environmental change inferred from the Cocha Caranga sediment and soil records in the southeastern Ecuadorian Andes. Palaeogeography, Palaeoclimatology, Palaeoecology 276:1-14.

Niemann, H., and H. Behling. 2009b. Late Holocene environmental change and human impact inferred from three soil monoliths and the Laguna Zurita multi-proxi record in the southeastern Ecuadorian Andes. Vegetation History and Archaeobotany 19:1-15.

Niemann, H., C. Brunschön, and H. Behling. 2010. Vegetation/modern pollen rain relationship along an altitudinal transect between 1920 and 3185ma.s.l. in the Podocarpus National Park region, southeastern Ecuadorian Andes. Review of Palaeobotany and Palynology 159:69-80.

Niemann, H., T. Haberzettl, and H. Behling. 2009. Holocene climate variability and vegetation dynamics inferred from the (11700 cal. yr BP) Laguna Rabadilla de Vaca sediment record, southeastern Ecuadorian Andes. The Holocene 19:307-316.

Opler, P., G. Frankie, and H. Baker. 1980. Comparative phenological studies of treelet and shrub species in tropical wet and dry forests in the lowlands of Costa Rica. Journal of Ecology 68:167-188.

Parsons, R., and I. Prentice. 1981. Statistical approaches to R-values and the pollen- vegetation relationship. Review of Palaeobotany and Palynology 32:127-152.

Prentice, I. 1985. Pollen representation, source area, and basin size: Toward a unified theory of pollen analysis. Quaternary Research 23:76-86.

Prentice, I., and T. Webb. 1986. Pollen percentages, tree abundances and the Fagerlind effect. Journal of Quaternary Science 1:35-43.

Richter, M., K.-H. Diertl, T. Peters, and R. Bussmann. 2008. Vegetation Structures and Ecological Features of the Upper Timberline Econtone. Pages 1-13 in E. Beck, J. Bendix, I. Kottke, F. Makeschin, and R. Mosandl, editors. Gradients in a tropical mountain ecosystem of Ecuador. Springer, Berlin.

Sakai, S. 2001. Phenological diversity in tropical forests. Population Ecology 43:77-86.

Tauber, H. 1967. Differential pollen dispersion and filtration. Pages 131-141 in E. Cushing and $\mathrm{H}$. Wright, editors. Quaternary Paleoecology. Yale University Press, New Haven and London.

Weng, C., M. Bush, and M. Silman. 2004. An analysis of modern pollen rain on an elevational gradient in southern Peru. Journal of Tropical Ecology 20:113-124. 


\section{CHAPTER 6}

\section{Climate Change Effects on Biodiversity and Ecosystem}

\section{Functioning}

Florian A. Werner ${ }^{1,}{ }^{,}$, Nele Jantz ${ }^{2}$, Valentyna Krashevska ${ }^{3}$, Thorsten Peters ${ }^{4}$, Hermann Behling ${ }^{2}$, Mark Maraun ${ }^{3}$, Stefan Scheu ${ }^{3}$, Gunnar Brehm ${ }^{5}$

${ }^{1}$ Functional Ecology, Institute of Biology and Environmental Sciences, Carl von Ossietzky University Oldenburg

${ }^{2}$ Palynology and Climate Dynamics, Albrecht von Haller Institute of Plant Sciences, Georg August University of Göttingen

${ }^{3}$ J.F. Blumenbach Institute of Zoology and Anthropology, Animal Ecology, Georg August University of Goettingen

${ }^{4}$ Institute of Geography, FAU Erlangen-Nuremberg

${ }^{5}$ Institute of Systematic Zoology and Evolutionary Biology with Phyletic Museum

* Corresponding author: florian.werner@uni-oldenburg.de

In Bendix, J., E. Beck, A. Bräuning, F. Makeschin, R. Mosandl, S. Scheu, and W. Wilcke, editors.

Ecosystem Services, Biodiversity and Environmental Change in a Tropical Mountain Ecosystem of South Ecuador. Ecological Studies Vol. 221, Pp. 247-263. Springer, Berlin. 


\section{Abstract}

Understanding the resistance of plant and decomposer communities to climate change is critical for predicting the future of tropical biodiversity and ecosystem functioning. In this chapter we present data from three independent field studies related to climate change effects in the moist Andes of Southeast Ecuador. Pollen records suggest that large climatic fluctuations during the late Pleistocene and Holocene affected the unusually low forest line of southern Ecuador in ways that were expected, with warming trends resulting in an elevation of the timber line. However, our analysis of present-day tree assemblages at ten tree line sites suggests that the regional timberline is not primarily determined by temperature, and that rising temperature alone is hence unlikely to cause a pronounced upshift of the region's tree line. Experimental rain exclusion strongly reduced the density, but not the species richness, of testate amoebae irrespective of altitude $(1,000-3,000 \mathrm{~m})$, suggesting that increasing drought occurrence may affect nutrient cycling in the future.

\subsection{Introduction}

Human activities are profoundly altering the Earth's climate. Temperatures in the tropical Andes have already increased by $0.6^{\circ} \mathrm{C}$ over pre-industrial levels. Climate models anticipate temperatures to increase by $2-5^{\circ} \mathrm{C}$ during the course of this century and predict that major shifts in precipitation patterns will occur in tropical South America as in many other regions (IPCC 2007). While rainfall is projected to increase in some regions, it is likely to diminish in others, such as our study region in the Andes of southern Ecuador (Chaps. 2 and 19 of the same Ecological Studies volume). Moreover, condensation levels are expected to rise, affecting patterns of horizontal precipitation by fog and wind-driven rain in tropical mountains (Marengo et al. 2011). Global climate change also affects precipitation seasonality. Extreme climate events (e.g., torrential rains, droughts) are increasing in frequency and severity in many parts of the world. Diminishing cloud cover may further exacerbate the effects of drought. These macroclimatic changes are likely to have severe effects on the biodiversity and functioning of tropical Andean ecosystems (Herzog et al. 2011).

Water availability (precipitation) and plant water demand (as a function of the vapour pressure deficit) change rapidly with altitude and exposure, and these gradients are frequently amplified by rain shadows (lee effect). As a result, water stress for primary producers is distributed very heterogeneously across the Andes (Richter et al. 2009) and in the study area (Fries et al. 2012). It is assumed that this remarkable mesoclimatic complexity has strongly facilitated speciation by 
effectively separating populations (Fjeldså 1994), and today the tropical Andes foster an unsurpassed

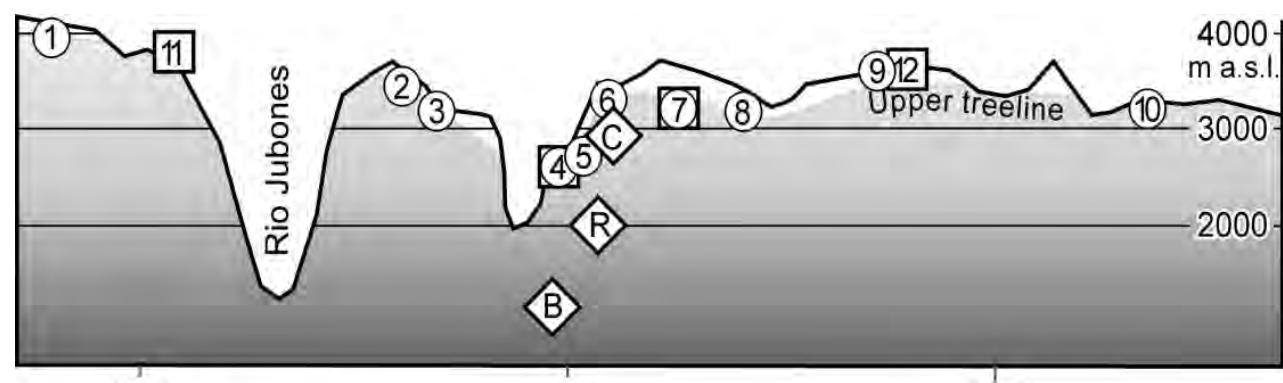

$3^{\circ} \mathrm{S}$ $4^{\circ} \mathrm{S}$ $5^{\circ} \mathrm{S}$

Study sites:

Upper treeline:

(1) El Cajas

(2) Fierro Urco

(3) Saraguro

(4) El Tiro

(5) Cerro del Consuelo

\section{Palynology:}

(6) Cajanuma

(7) Rabadilla de Vaca

(8) Cerro Toledo

(9) Amaluza

(10) Huancabamba
11 Tres Lagunas

4 EI Tiro

7 Rabadilla de Vaca

12 Natosas Turbera

Testate amoebae:

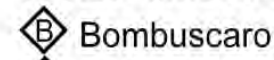

B. RBSF

Cajanuma

density of species

(Myers et al. 2000; Mutke and Barthlott 2005; Herzog et al. 2011). Many Andean taxa are restricted to narrow ranges

Fig. 1 Profile of the Eastern Andean Cordillera across the Andean depression ("Huancabamba Depression") of southern Ecuador and northern Peru, showing the ten study sites at the tree line. Digital elevation model based on United States Geological Survey (SRTM) dataset 2008.

temperature and humidity, resulting in high rates of endemism and species turnover across altitude and surface space (Kessler 2002; Brehm et al. 2003). It is therefore anticipated that climate change will require compensatory species range shifts (Colwell et al. 2008), processes which are obstructed by widespread anthropogenic habitat fragmentation (Chap. 7 of the same volume; Bush 2002; Hole et al. 2011). Understanding the resistance of plant and animal communities to climate change effects is critical for predicting the future of tropical biodiversity. There is growing evidence that a high degree of biodiversity and the presence of functionally "redundant" species are not a luxury, but rather a necessity for providing ecosystem resilience to environmental fluctuations (Isbell et al. 2011; Maestre et al. 2012; Zhang et al. 2012). The resistance of individual species and entire guilds or functional types of microorganisms, animals and plants to changes in climate may therefore also predict the stability of key ecosystem processes and services such as the provision of soil fertility, water interception, carbon storage and forest products for human use (Chap. 4, Chap. 7 of the same volume).

Decomposition of organic matter is one such critical ecosystem process. Effective cycling of nutrients through decomposition is vital for maintaining ecosystem productivity. Soil microfauna play a key role in the decomposition of plant matter and respond rapidly to changes in soil moisture (Vitousek et al. 1994; Epstein et al. 2002). Decomposer communities in acidic tropical forest soils mainly comprise microorganisms and microfauna including protists, especially testate amoebae, whereas macrofauna play a subordinate role (Schönborn 1973; Illig et al. 2005; 
Krashevska et al. 2007). Testate amoebae play an important role in carbon and nutrient cycling by consuming bacteria, fungi, algae, other protists and small metazoans (Wilkinson and Mitchell 2010, Krashevska et al. 2010).

The single most pronounced discontinuity along altitudinal gradients is the transition from forest to grassland at the forest line, defining ecosystems of contrasting water, carbon and mineral nutrient dynamics, and species composition. The tree line is determined by the mean growing season temperature in many parts of the world (Körner 2007), and is generally expected to rise with global warming. However, the upper limit of tropical forest growth often appears to be codetermined by additional environmental parameters such as high levels of solar radiation, wind stress, water-logging of soils, aluminium toxicity, and nutrient deficiency (Kessler and Hohnwald 1998, Bader et al. 2007a, 2007b; Peters 2009; Chap. 12 of the same volume). In some places such additional environmental driving forces may entirely replace temperature as determinants of the forest line position (Allen and Walsh 1996, Holtmeier 2003). The Andean depression of northern Peru and southern Ecuador is characterized by an unusually low tree line. Knowing which environmental parameters determine its particular position is a prerequisite for predicting the behavior of this line in the future. Pollen preserved in soils, bogs and lake sediments comprise an archive of vegetation responses to past climate oscillation. Studying the consequences of past climate change events through palynological techniques therefore offers a unique opportunity for predicting the response of plant communities to future climate change.

A general review of the effects of climate change on tropical Andean biodiversity and ecosystem services is beyond the scope of this chapter and has been addressed thoroughly elsewhere (e.g., Herzog et al. 2011). In this article we present original data from field studies at the Reserva Biológica San Francisco (RBSF) and its environs in southern Ecuador that address climate change effects on biodiversity, vegetation structure and ecosystem processes. We specifically address the following questions respective of the Andes of southern Ecuador:

a) How have the structure and composition of vegetation responded to climate fluctuations in the past?

b) How may continued atmospheric warming affect the altitudinal position of the tree line?

c) How are the abundance and diversity of soil microfauna (testate amoebae) affected by drought?

These questions are addressed by (1) palynological studies of vegetation responses to climate fluctuations in the past, (2) analysis of tree species composition at the timber line, and (3) simulating the effects of drought on testate amoebae in forest soil. 


\begin{tabular}{|c|c|c|c|c|}
\hline $\begin{array}{l}\text { Study } \\
\text { (time period, altitude) }\end{array}$ & $\begin{array}{l}\text { Geographical } \\
\text { position }\end{array}$ & $\begin{array}{l}\text { Transect altitude } \\
\text { [m a.s.l.] }\end{array}$ & $\begin{array}{l}\text { Tmean } \\
{\left[{ }^{\circ} \mathrm{C}\right]}\end{array}$ & $\begin{array}{l}\text { Number of total tree } \\
\text { species (mean species } \\
\text { number per transect) }\end{array}$ \\
\hline El Cajas & $2^{\circ} 46^{\prime} \mathrm{S} ; 79^{\circ} 12^{\prime} \mathrm{W}$ & $3470-4140$ & & $22(5.3)$ \\
\hline $\begin{array}{l}\text { Fierro Urco } \\
(23.5 .07-6.2 .08 ; 3500 \mathrm{~m})\end{array}$ & $3^{\circ} 43^{\prime} \mathrm{S} ; 79^{\circ} 19^{\prime} \mathrm{W}$ & $3480-3600$ & $\begin{array}{l}\text { Ta } 6.4 \\
\text { Ts } 9.1\end{array}$ & $28(7.5)$ \\
\hline $\begin{array}{l}\text { Saraguro } \\
(23.5 .07-6.2 .08 ; 3350 \mathrm{~m})\end{array}$ & $3^{\circ} 40^{\prime} \mathrm{S} ; 79^{\circ} 14^{\prime} \mathrm{W}$ & $3210-3300$ & $\begin{array}{l}\text { Ta } 7.4 \\
\text { Ts } 11.3\end{array}$ & $66(16.4)$ \\
\hline El Tiro & $3^{\circ} 58^{\prime} \mathrm{S} ; 79^{\circ} 8^{\prime} \mathrm{W}$ & $2790-2820$ & & 39 (11.5) \\
\hline $\begin{array}{l}\text { Cerro del Consuelo } \\
(1.1 .98-17.9 .06 ; 2930 \mathrm{~m})\end{array}$ & $3^{\circ} 59^{\prime} \mathrm{S} ; 79^{\circ} 3^{\prime} \mathrm{W}$ & $2760-3030$ & $\begin{array}{l}\text { Ta } 9.6 \\
\text { Ts } 11.4\end{array}$ & $40(10.4)$ \\
\hline $\begin{array}{l}\text { Cajanuma } \\
(1.1 .98-17.9 .06 ; 3400 \mathrm{~m})\end{array}$ & $4^{\circ} 7^{\prime} \mathrm{S} ; 79^{\circ} 9^{\prime} \mathrm{W}$ & $3170-3320$ & $\begin{array}{l}\text { Ta } 6.8 \\
\text { Ts } 10.5\end{array}$ & $20(6.6)$ \\
\hline Rabadilla de Vaca & $4^{\circ} 15^{\prime} \mathrm{S} ; 79^{\circ} 7^{\prime} \mathrm{W}$ & $3150-3350$ & & $44(9.3)$ \\
\hline Cerro Toledo & $4^{\circ} 22^{\prime} \mathrm{S} ; 79^{\circ} 6^{\prime} \mathrm{W}$ & $3030-3280$ & & $43(12.6)$ \\
\hline $\begin{array}{l}\text { Amaluza } \\
(7.10 .06-3.3 .07 ; 3650 \mathrm{~m})\end{array}$ & $4^{\circ} 44^{\prime} \mathrm{S} ; 79^{\circ} 25^{\prime} \mathrm{W}$ & $3480-3590$ & $\begin{array}{l}\text { Ta } 5.6 \\
\text { Ts } 8.9\end{array}$ & $46(12.6)$ \\
\hline Huancabamba & $5^{\circ} 20^{\prime} \mathrm{S} ; 79^{\circ} 32^{\prime} \mathrm{W}$ & $3040-3270$ & & $46(10.0)$ \\
\hline
\end{tabular}

\subsection{Material and Methods}

\subsubsection{Palynological Studies of Past Vegetation Dynamics}

We studied four sediment cores. Peat bog cores were taken with a Russian peat corer, lake cores with a Livingston piston corer. All cores were dated by accelerator mass spectrometry radiocarbon dating. Core $1(127 \mathrm{~cm}$, sampled at intervals of $2 \mathrm{~cm}$ ) was taken at a peat bog situated at the pass El Tiro (Niemann and Behling 2008) on the eastern Cordillera on the border of the Podocarpus National Park (2,810 m a.s.I.; 03 59'25.9” S, 7908'43.2" W). This area is covered today by Subpáramo vegetation, with important taxa being Puya nitida (Bromeliaceae), Brachyotum rotundifolium (Melastomataceae) and Oritrophium peruvianum (Asteraceae). Core 2 (114 cm, sampled at intervals of $2 \mathrm{~cm}$ ) was taken at Tres Lagunas (Jantz and Behling 2012), a bog in the Quimsacocha volcanic basin (3,780 m; 0302'50.9' S, $79^{\circ} 14^{\prime} 29.9^{\prime \prime} \mathrm{W}$ ) on the eastern slope of the western Cordillera. The prevailing vegetation at this site is at present grass Páramo dominated by tussock grasses (Stipa, Calamagrostis). Two additional cores were taken at two lakes: Lagunas Natosas Turbera $\left(3,482 \mathrm{~m}, 04^{\circ} 43^{\prime} 56.6^{\prime \prime} \mathrm{S}, 79^{\circ} 25^{\prime} 41.2^{\prime \prime} \mathrm{W}, 208 \mathrm{~cm}\right.$, sampled at intervals of $4 \mathrm{~cm}$, very close to the core Lagunas Natosas Bosque discussed in chapter 5 of the 
same volume) and Laguna Rabadilla de Vaca (3,312 m, 04¹5'19.7” S, 7906'43.7” W, $490 \mathrm{~cm}$, sampled at intervals of $10 \mathrm{~cm}$, very close to the core Rabadilla de Vaca mire, discussed in chapter 5 of this volume) (Niemann et al. 2009). These lakes are now surrounded by herbaceous Páramo dominated by Neurolepis and Calamagrostis (Poaceae). A detailed description of methods for sampling and sample processing is provided by Faegri and Iversen (1989). To determine the nature, severity and frequency of the vegetation changes evident from our cores, we conducted Principal Component Analysis (PCA) with the programs CANOCO and CanoDraw (ter Braak and Šmilauer 2002). The velocity, or rate, of vegetation change is defined as the amount of change having taken place in a community composition per unit time (Orlóci et al. 2002). The determination of this rate can be helpful in detecting past environmental change; we calculated it using the software Multiv (Pillar 2001).

\subsubsection{Tree Species Diversity at the forest line}

Tree communities were studied at ten tree line sites in southern Ecuador and northernmost Peru (Fig. 1; Table 1). Transects were laid out in closed-canopy forest stands near the transition to subpáramo where maximum stem diameter still commonly exceeded $5 \mathrm{~cm}$. At each site the

number of species of trees having a stem diameter $>5 \mathrm{~cm}$ at $0.3 \mathrm{~m}$ above ground level were recorded for eight transects of $50 \times 2 \mathrm{~m}$ each following Gentry (1982; see Peters 2009 for details). Data loggers recorded soil (10 cm depth) and air ( $2 \mathrm{~m}$ above ground) temperature every 10 minutes and stored the hourly mean values. The known altitudinal distribution ranges of tree species were retrieved from the Tropicos database of the Missouri Botanical Garden (2011).

\subsubsection{Drought Effects on Testate Amoebae}

We reduced the amount of rainfall impacting on investigation plots by installing white plastic roofs of $1.5 \times 1.5 \mathrm{~m}$ area at a height of $1.5 \mathrm{~m}$. On the upslope sides of the plots, $50 \mathrm{~cm}$ high plastic fences were dug $30 \mathrm{~cm}$ deep into the soil to prevent near-surface water from flowing into the plots. All sides of the plots were open to allow free air circulation. Roofs of control plots were covered by $5 \times 5 \mathrm{~mm}$ mesh. This allowed free water entry but prevented litter fall, since this was also excluded from the plots covered by the closed plastic roofs. Four replicates of the meshed and closed roofs were established at each of 1,000 m (Bombuscaro, Podocarpus NP; 04 ${ }^{\circ} 11^{\prime} 46.0^{\prime \prime}$ S, $078^{\circ} 96^{\prime} 82.9^{\prime \prime} \mathrm{W}$ ), 2,000 m (RBSF; 0398'14.4" S, 079 $08^{\prime} 28.2^{\prime \prime} \mathrm{W}$ ) and 3,000 m altitude (Cajanuma, Podocarpus NP; S 04 $10^{\prime} 93.7^{\prime \prime}$ S, 079¹7'99.4" W), resulting in a total of 24 plots. Samples from the litter and fermentation layers were taken 15 months later from each plot to a depth of $5 \mathrm{~cm}$ using a soil corer $(\varnothing 5 \mathrm{~cm})$. Testate amoebae were extracted by washing samples over a filter of $500 \mu \mathrm{m}$ mesh and then back-sieving the filtrate through $20 \mu \mathrm{m}$ mesh. Microscopic 
slides were prepared from the final filtrate and testate amoebae were identified and counted (for details see Krashevska et al. 2007, 2012). Density of testate amoebae was analyzed by two-factor randomized complete block analysis of variance (ANOVA) with the fixed factors rain exclusion (with and without) and altitude $(1,000,2,000$ and 3,000 m). We used Discriminant Function Analysis (DFA) as implemented in STATISTICA 7.0 to identify drought effects on testate amoeba communities.

\subsection{Results and Discussion}

\subsubsection{Palynological Studies of Past Vegetation Dynamics}

Each of the four study sites has been subjected to particular individual climate changes (Fig. 2). Even though regional and global climates can be key predictors of vegetation dynamics, specific microclimatic conditions as well as other abiotic and biotic factors exert an influence on sites, which should not be neglected when interpreting paleo-environmental records. Every core thus has its own story and should be interpreted individually.

In the late Pleistocene (20,000-11,500 cal. yr [calibrated years] before present [BP]) herbaceous taxa dominated the pollen assemblages of the El Tiro record (Fig. 2). These taxa indicate that the area was covered by a grass Páramo at that time, hence reflecting a lower forest line than that of today, which was related to cooler conditions. Together with Alnus acuminata, the only tree species of major importance during this period, these herbaceous taxa may indicate disturbance or primary succession on highly minerogenic soils (Weng et al. 2004; Brunschön and Behling 2009).

A clear directional change towards sub-Páramo and upper montane forest communities is visible at the end of the Pleistocene after $\sim 11,800 \mathrm{cal}$. yr BP. The increasing importance of woody taxa and ferns indicates not only warming but also the prevalence of moist conditions during this period at El Tiro (Fig. 2). However, the presence of tree pollen during the glacial period should be interpreted cautiously, since strong wind fields would likely have caused increased intake of tree pollen from lower, forested altitudes. While turnover velocity at El Tiro did not change markedly during the Pleistocene, the Lagunas Natosas Turbera core (3,600 $\mathrm{m}$ a.s.I.) evidenced a high rate of change towards the end of the Pleistocene as compared to the early Holocene (Fig. 3). Forest taxa at this site were less abundant during the Holocene than during the Pleistocene, which in turn may be due to a changing wind regime and/or warmer climate. Increasing temperature, here indicated by the steady increase in the number of forest taxa, is a typical climate signal for the period between the late Pleistocene and the early Holocene and can be found in many other records throughout the globe. This directional warming trend in the trajectory at El Tiro continued 
until approximately 6,000 cal. yr B.P as indicated by an upslope shift of montane forest taxa from $\sim 2,100 \mathrm{~m}$ to $2,600 \mathrm{~m}$ a.s.I. (Brunschön and Behling 2010). Data from Tres Lagunas indicate that the climate was relatively dry and possibly warmer than at present during the period of from 7,600 to 2,500 cal. yr BP, since taxa of dry Páramo vegetation (e.g. Fabaceae, Lamiaceae, Poaceae) prevail. The sediment itself also points to a relatively dry environment, since $>5,000$ years are represented in only $11 \mathrm{~cm}$ of sediment $(110.5 \mathrm{~cm}=7,672 \pm 37 \mathrm{cal}$. yr BP to $98.7 \mathrm{~cm}=$ $2,242 \pm 66$ cal. yr BP). Even though we cannot exclude a hiatus or mixing of the sediment, the notion that sediment accumulation was low during the mid-Holocene is supported by very high pollen and charcoal concentrations, likely caused by rapid peat decomposition in a warmer climate (Coûteaux et al. 2002). Strong decomposition was likewise evident at El Tiro. Drier conditions may have resulted in a high sensitivity of peat composition to temperature and an intense loss of soil organic carbon (Ise et al. 2008). A mid-Holocene dry event has previously been recorded throughout the northern and central Andes region (Ecuador, Peru and Bolivia) (Hansen et al. 2003; Paduano et al. 2003; Weng et al. 2006; Niemann et al. 2009; Niemann and Behling 2009) and for the Amazon lowlands (Behling and Hooghiemstra 2000; Mayle et al. 2000). However, this dry event is not reflected in pollen records to a similar extent everywhere in the eastern Andes of southern Ecuador, and some cores (e.g., Cerro Toledo, Brunschön and Behling 2009) even indicate rather moist conditions. The velocity curves of all four records show marked peaks at 7,000 cal. yr BP, corresponding to a warming event at this time (Behling and Pillar 2007).

During the mid- and late Holocene period (from 6,000 yr BP until today), vegetation trajectories no longer show a directional pattern. Human impact may have blurred climatic signals, e.g. through the increased incidence of forest fires. A chaotic pattern is also reflected by the turnover of all cores, which exhibit irregular oscillations and poorly pronounced peaks. Both cores show an increasing importance of woody taxa throughout the last approximately 2,000 yr. Stronger human impact during the last 100 years is visible particularly at Tres Lagunas in terms of an increase in introduced taxa (Juglans, Pinus, Schinus) and high turnover velocities. At El Tiro and Tres Lagunas, charcoal records indicate high fire intensities at least since the beginning of the late Holocene (Jantz and Behling, 2012, Niemann and Behling, 2009), and tracks of human influence in the region around Loja can be dated back to $~ 4,600 \mathrm{BP}$ (see Chapter 5 in the same volume).

Due to the local microclimatic influences, most observations are not valid for all sites but rather show a regional to local picture of environmental change.

Nevertheless, time trajectory analyses and velocity values indicate that three main periods of environmental change altered the composition and structure of vegetation (see also Chapter 5 of the volume): 

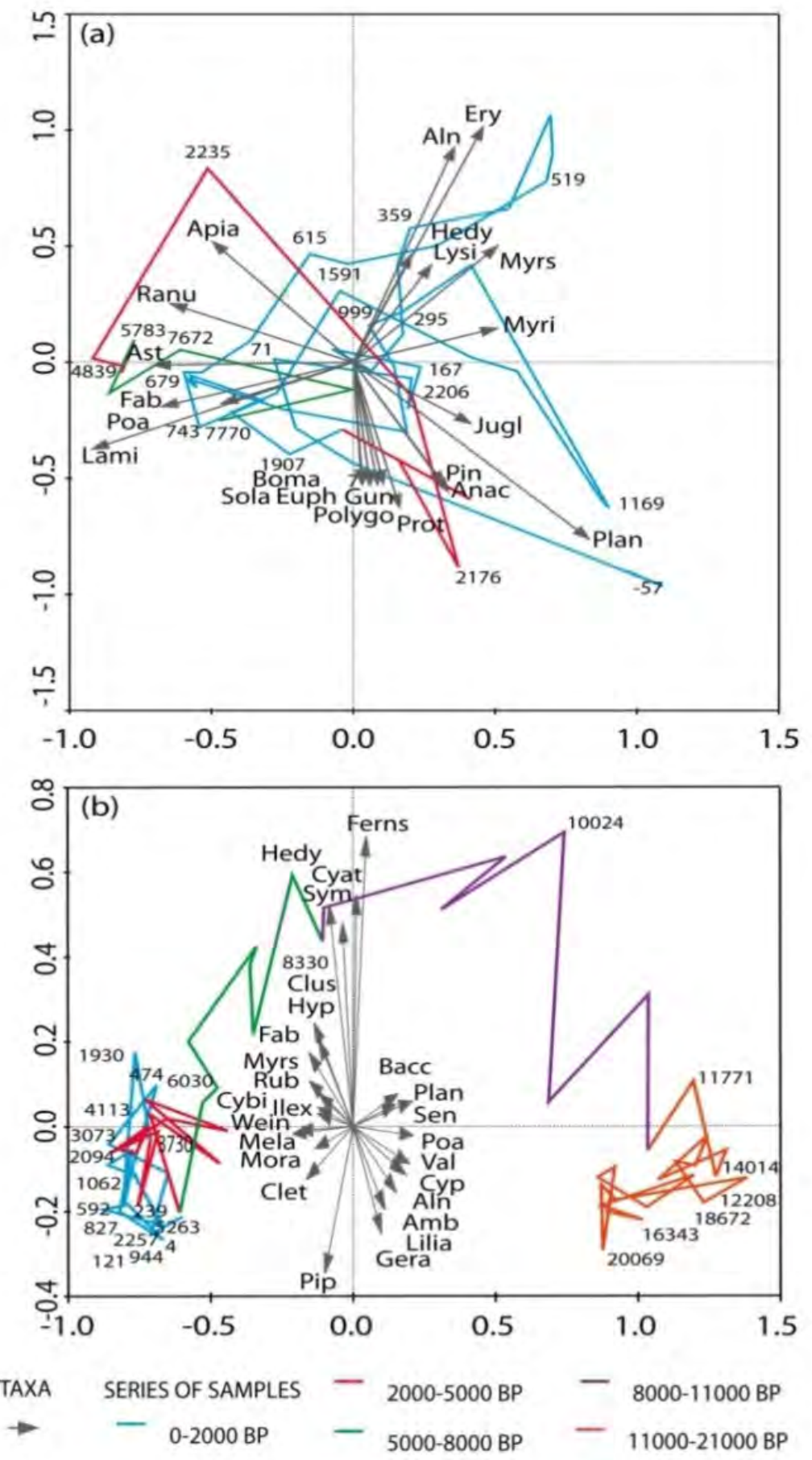

Figure 2 Time trajectory of pollen data from the sediment cores at a) El Tiro and b) Tres Lagunas. PCA ordination (eigenvalues 0.681 and 0.055 for El Tiro, 0.249 and 0.187 for Tres Lagunas) follows Orlóci (2002). Taxa scores are marked by arrows. Taxon abbreviations are as follows: Aln - Alnus ${ }^{2}$, Amb - Ambrosia type ${ }^{1}$, Anac - Anacardiaceae ${ }^{2}$, Apia-Apiaceae ${ }^{1}$, Ast - Asteraceae ${ }^{1}$, Bacc - Baccharis type ${ }^{1}$, Boma - Bomarea type ${ }^{1}$, Clet - Clethra type ${ }^{2}$, Clus Clusiaceae, Cya-Cyatheaceae ${ }^{2}$, Cybi-Cybianthus ${ }^{2}$, Cyp - Cyperaceae ${ }^{1}$, Ery-Eryngium type ${ }^{1}$, Euph - Euphorbiaceae ${ }^{2}$, Fab - Fabaceae ${ }^{3}$, Ferns - Filicatae (excluding Cyatheaceae) ${ }^{3}$, Gera - Geranium ${ }^{1}$, Gun - Gunneraceae ${ }^{3}$, Hedy Hedyosmum $^{2}$, Hyp - Hypericum ${ }^{1}$, Ilex - Ilex ${ }^{2}$, Jugl - Juglans ${ }^{2}$, Lami - Lamiaceae ${ }^{1}$, Lilia - Liliaceae ${ }^{1}$, Lysi - Lysipomia ${ }^{1}$, Mela

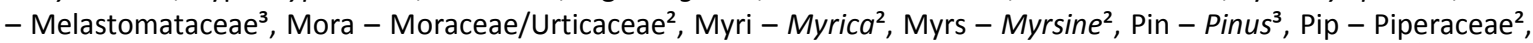
Plan - Plantago ${ }^{1}$, Poa - Poaceae ${ }^{1}$, Polygo - Polygonaceae ${ }^{1}$, Prot- Proteaceae ${ }^{3}$, Ranu - Ranunculaceae ${ }^{1}$, Rub Rubiaceae $^{3}$, Sen - Senecio type ${ }^{1}$, Sola - Solanum type ${ }^{2}$, Sym - Symplocos ${ }^{2}$, Wein - Weinmannia type ${ }^{2}$.

${ }^{1}$ Taxa mainly occurring in Páramo, ${ }^{2}$ taxa mainly occurring in forest, ${ }^{3}$ taxa occurring in both forest and Páramo. Note that Pinus is an introduced timber tree. 


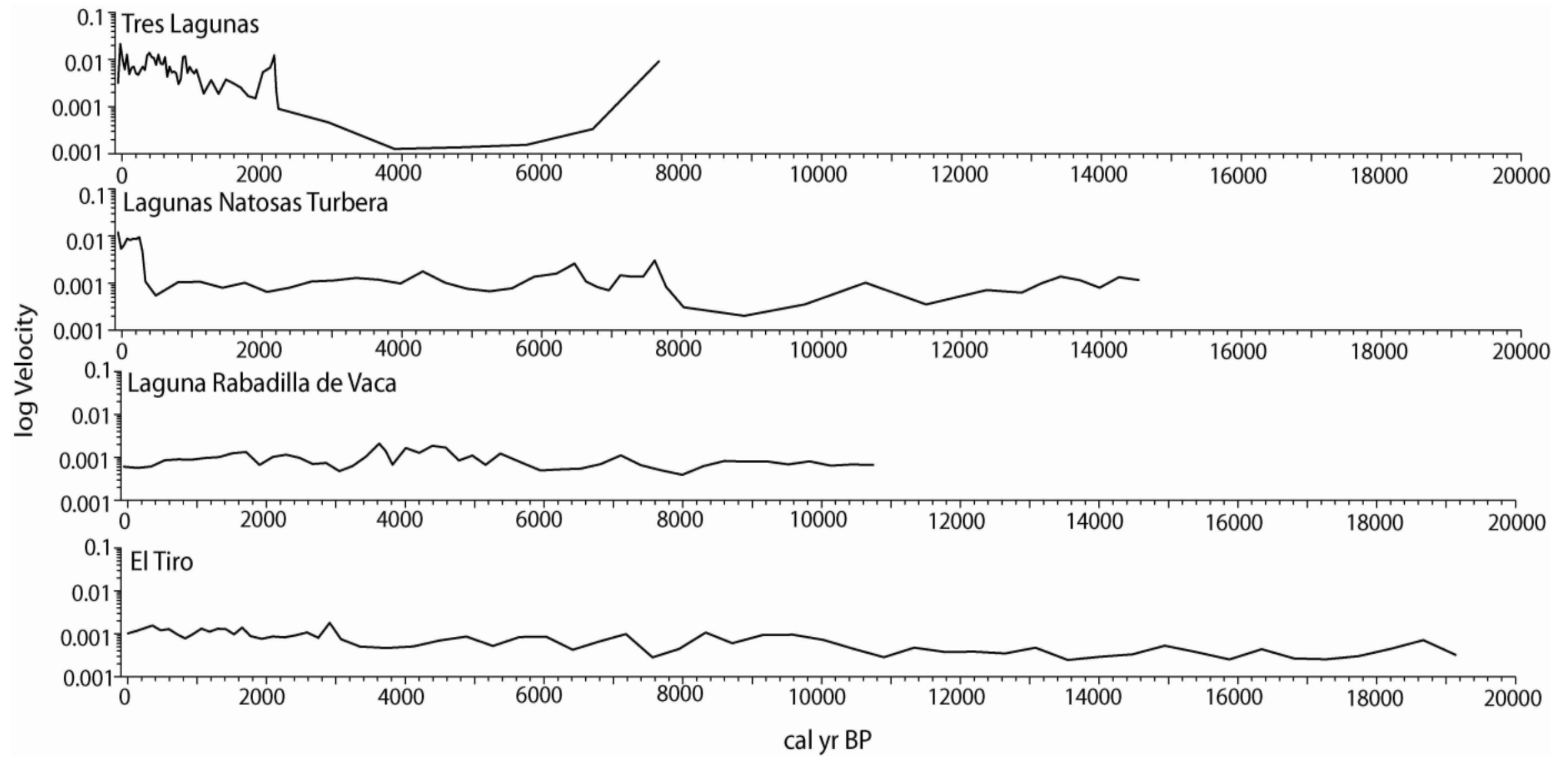

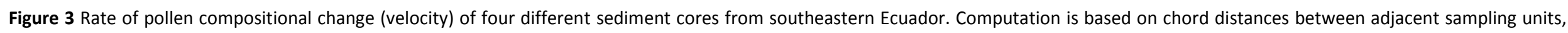
using percentage data brought to the lowest common taxonomic level. The timescale is based on the linear interpolation of calibrated years BP (cal. yr BP). 
1. The climatic transition from the Pleistocene to the Holocene at $\sim 11,500$ cal. yr BP which caused an upslope shift of the upper forest line.

2. The early to mid-Holocene dry and warm event from 8,000-5,000 cal. yr BP which led to an increase of drought tolerant taxa and/or to a further upward shift of the upper forest line.

3. The growing human impact during the last $\sim 2,000$ cal. yr BP which led to the increase in fire intensity and the spread of taxa that indicate disturbance and/or agricultural activity.

During the late Holocene, the vegetation development indicates a strong human impact at all sites. It seems that since that time anthropogenic influence has a stronger effect on vegetation changes than does climate since.

\subsubsection{Tree Species Diversity at the forest line}

We found 239 tree species from 39 different families at ten tree line sites. The most species-rich families were Melastomataceae (29 spp.), Asteraceae (19 spp.) and Cunoniaceae (12 spp.), while Melastomataceae and Cunoniaceae were the most abundantly represented, contributing $20 \%$ and $14 \%$ of all individuals, respectively. The highest number of 66 tree species was found at the site Saraguro, where human disturbance has promoted high densities of thin stems. El Cajas stands out in exhibiting the highest forest line (Table 1) and is the only site dominated by Polylepis spp. (Rosaceae). Together with Cajanuma this site also had the lowest number of species (20 in each case). Unlike in the case of Cajanuma, however, the low species richness at El Cajas was not related to low stem density. Considering that the Andean tree line is typically composed of one to

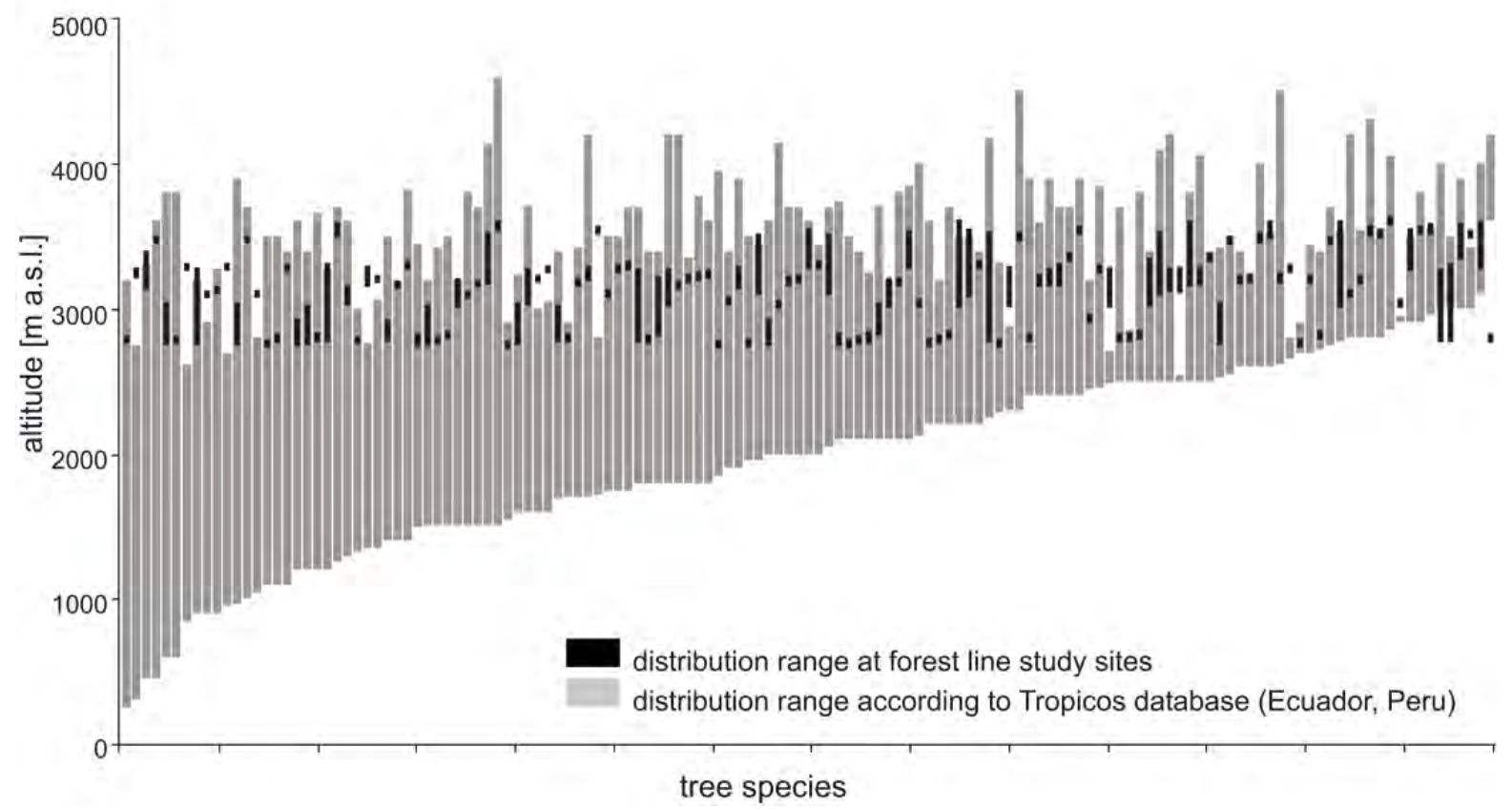

Figure 4 Tree species occurrence at tree line sites in southeastern Ecuador and northern Peru (ranges shown by black bars) relative to their distribution ranges in Ecuador and Peru according to the Tropicos database of the Missouri Botanical Garden (grey bars). Because El Cajas is located outside of the Huancabamba depression of the Andes, data from this site are excluded. 
only a few tree species (Baumann 1988; Kessler 1995), the overall tree species richness at our study sites was remarkably high (Table 1 ). Of the 139 species identified, $80 \%$ have previously been registered at higher altitudes in Ecuador and Peru (Fig. 4), and only 20\% were found at locations higher than their formerly known upper distribution limits. Given that the mean soil temperatures at our sites were well above $5.5^{\circ} \mathrm{C}$ (Table 1 ) - the postulated global threshold value for tree growth within the tropics (Körner 2007) - temperature is unlikely to pose a principal and general limitation to tree competitiveness at the low forest line in the region of our study. Other environmental factors such as extraordinary high incidence of solar irradiation (Emck and Richter 2008; Peters 2009), quasi-permanent and stiff trade winds, and high amounts of annual precipitation may pose influential co-controls over the present position of the tree line. While high global irradiation causes radiation stress for tree seedlings outside closed forest stands (Bader 2007b), strong easterly winds constitute an additional constraint to the establishment of forests, especially near crest lines (Richter et al. 2008). Moreover, precipitation is exceptionally copious (up to 5,000 $\mathrm{mm} \mathrm{yr}^{-1}$ ) at high elevations in the center of the Andean Depression (Emck 2007; Rollenbeck and Bendix 2011; Chap. 1). This may lead to excessive nutrient leaching, water logging and soil oxygen depletion.

Our conclusion that the low forest line in southern Ecuador and northern Peru is not primarily temperature-driven is also supported by the altitudinal distribution ranges of the tree species at our sites. Many species have previously been recorded to occur at substantially higher elevations elsewhere in Ecuador and Peru (Fig. 4), suggesting that their upper altitudinal distribution limit at our forest line sites is not a function of low temperature. Most of the tree species have also been recorded at substantially lower elevations elsewhere (Fig. 4), suggesting that warming alone should have but a moderate direct effect on the vertical distribution of many resident tree species, although it may facilitate the establishment of competitor species from lower elevations. However, this conclusion should be viewed with caution. The extraordinarily large altitudinal ranges of some of the species according to the database Tropicos (Fig. 4) point to the presence of artifacts stemming from the misidentification of plant specimens or a lumping of poorly differentiated species. Detailed and reliable distribution records are a vital prerequisite for the construction of meaningful and trustworthy eco-climatic species envelopes and the prediction of biodiversity responses to climate change. The low number of experts for the taxonomy of complex tropical plant taxa has created a bottle-neck for progress in our knowledge of species ranges and the projection of their response to climate change (Gotelli 2004; Brehm et al. 2008). 


\subsubsection{Drought Effects on Testate Amoebae}

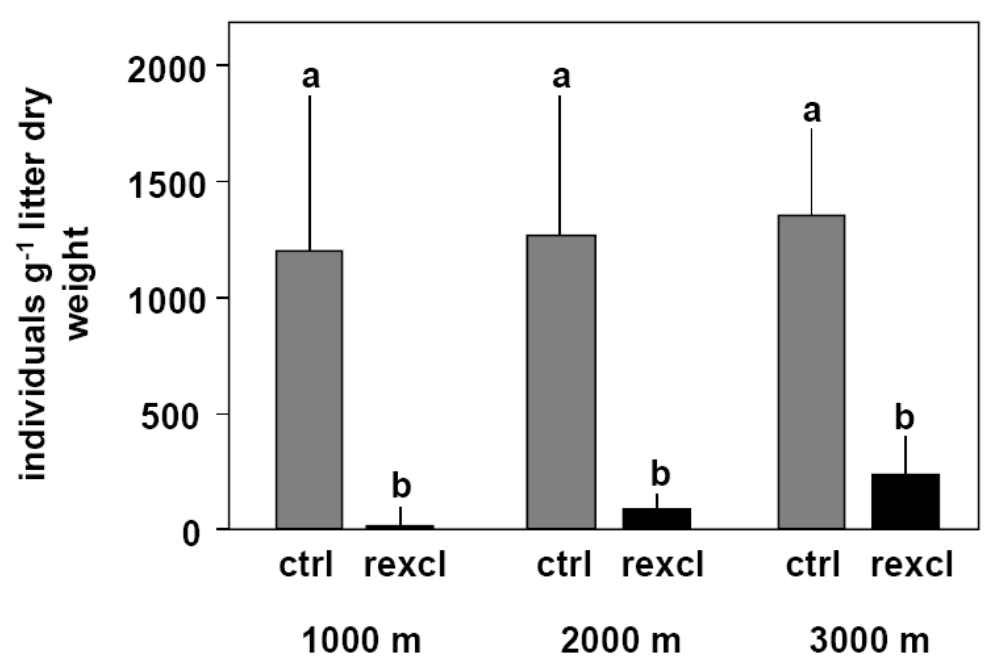

Figure 5 Effect of experimental rain exclusion on the density of live cells of testate amoebae in the litter and fermentation layers (0-5 cm depth) at three altitudes $(1,000,2,000$ and $3,000 \mathrm{~m}$ a.s.l.). Means and standard deviations $(\mathrm{n}=4)$ are shown for control (ctrl) and rain exclusion treatments (rexcl). Different letters above the columns indicate significant differences between treatments (Tukey's HSD test following ANOVA, $p<0.05$ ).

A total of 112 taxa of testate amoebae were identified. Only 66 taxa represent live specimens. Communities of testate amoebae found at 3,000 m differed markedly from those at 2,000 and $1,000 \mathrm{~m}$. The sites at 2,000 and 3,000 $\mathrm{m}$ a.s.l. shared $50 \%$ of the total number of live taxa, while those at 1000 and $2,000 \mathrm{~m}$ shared $36 \%$ and those at 1,000 and $3,000 \mathrm{~m}$ only 28\%. Overall, rain exclusion did not affect the species number of live testate amoebae significantly; however, the density of live specimens in rain exclusion plots was greatly reduced relative to control plots at all sites (Fig. 5). By contrast, the density of testate amoebae cysts was significantly higher in the rain exclusion plots than in the control plots at 2,000 and $3,000 \mathrm{~m}$ (ANOVA followed by Tukey HSD, p < 0.01), suggesting that testate amoebae become inactive at low soil moisture and form cysts (see Krashevska et al. 2012 for details).

Overall, 25 taxa of testate amoebae representing $37 \%$ of the total number of live

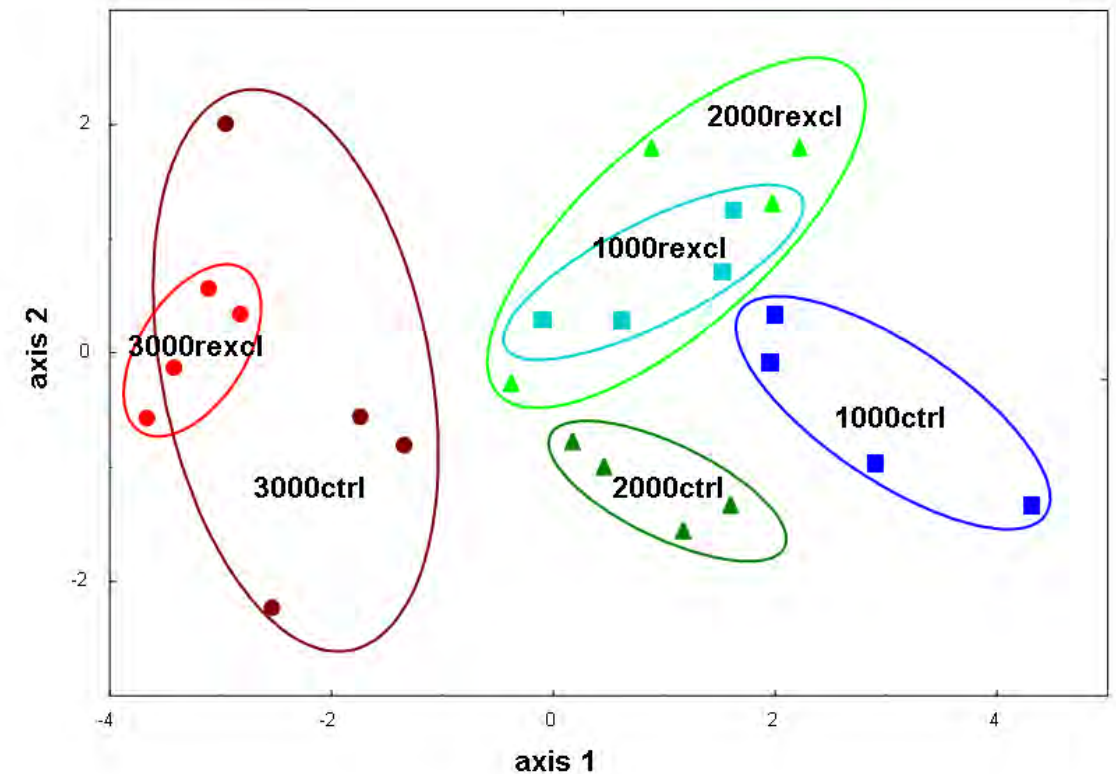

Figure 6 Discriminant function analysis of live cells of soil testate amoeba along an altitudinal transect (axis 1 ) and between control and rain exclusion treatments (axis 2). Control and rain exclusion treatments at 1,000 (1,000 ctrl, 1,000 rexcl), 2,000 (2,000 ctrl, $2,000 \mathrm{rexcl})$, and $3,000 \mathrm{~m}(3,000 \mathrm{ctrl}, 3,000 \mathrm{rexcl})$ altitude in S-Ecuadorian montane forest; ellipses represent confidence ranges at $\mathrm{p}=0.05$ 
specimens were affected by rain exclusion, i.e., were less commonly or not found in exclusion plots. The species composition of testate amoebae in exclusion plots was markedly different from control plots at 1,000 and 2,000 m but not at 3,000 m (Fig. 6). At this high elevation, the vapour pressure deficit is lowest (Emck 2007) and fog is an important source of precipitation (Bendix et al. 2004), which may have buffered the effects of rainfall exclusion.

The results of this study show that rain exclusion strongly affects testate amoebae density irrespectively of altitude. Microorganisms as a potential food resource for testate amoebae also were reduced in number by rain exclusion (Krashevska et al. 2012). However, the reduction was not as strong as that observed here in testate amoebae, suggesting that reduced moisture adversely affects testate amoebae not only via reduced food supply but also directly, possibly by restricting their movement (Sleigh 1989). The sensitive response of testate amoebae to moisture reduction indicates that trophic levels higher than those of microorganisms need to be included when monitoring environmental changes. Changes in microbial activity and biomass as well as changes in the community composition and density of higher trophic levels which result from changing climatic conditions are likely to alter central ecosystem processes profoundly.

\subsection{General Conclusions}

Our vegetation studies yielded partly ambiguous results. As expected, pollen records suggest that major warming events of the late Pleistocene and Holocene resulted in a shifting of the southern Ecuador tree line to a higher altitude. In contrast, our analysis of present-day tree assemblages suggests that rising temperature alone is rather unlikely to cause a pronounced uplift of the region's tree lines. However, a combination of warming and drying may have more dramatic effects on the forest line positioning in the near future. Our study region is extraordinarily humid at high altitudes (Emck 2007), which probably helped mitigate the adverse effects of reduced precipitation during the early to mid-Holocene. However, ongoing deforestation of the Amazon lowlands may cause a substantial reduction of precipitation in the eastern Cordillera over the coming decades (Malhi et al. 2008). If the strong anthropogenic pressure of the present day persists, a high frequency of human-lit fires may soon overstrain the resistance of vegetation to climate change. As a result, large tracts of forests of high carbon density (Chap. 10 of the same volume) could be replaced permanently by more resilient grass- and scrublands.

Simulated drought effects on soil testate amoebae further suggest that top-down forces in microbial food webs rely heavily on precipitation and associated high soil moisture. As testate amoebae are among the dominant grazers of microorganisms, changes in their community composition and density are likely to alter nutrient cycling and thus plant nutrient acquisition. Nutrients in Andean forest ecosystems are in large locked up in organic material that forms thick 
organic layers (Ließ 2010) resulting in strong nutrient limitations (Chap. 11 of the same volume). Under drier climatic conditions, reduced grazing of soil microorganisms by testate amoebae would be likely to aggravate nutrient deficiency and nutrient limitation for primary consumers and thereby reduce ecosystem productivity. Drying is also likely to affect numerous other ecosystem processes and services, e.g., strongly diminished abundance, survival and recruitment of epiphytes on isolated remnant trees in our study region (Nöske et al. 2008, Werner \& Gradstein 2008, Werner 2011) suggest that a general drying trend may also diminish epiphyte biomass in intact forest, affecting the interception of water and nutrients by forest canopies (Tobón et al. 2010).

The extent to which climate change will affect future providing ecosystem services in our study region must remain open due to the ambiguity and limited width of our study results. Our paper thus confirms that more effort ought to be invested in taxonomy, ecological inventories and experiments to project the consequences of global change for tropical Andean biodiversity and ecosystem functioning into the future.

\subsection{References}

Allen T., and S. Walsh. 1996. Spatial and compositional pattern of alpine treeline, Glacier National Park, Montana. Photogrammetric Engineering and Remote Sensing 62:1261-1268.

Bader M., M. Rietkerk, and A. Bregt. 2007a. Vegetation structure and temperature regimes of tropical alpine treelines. Arctic, Antarctic and Alpine Research 39:353-364.

Bader M., I. van Geloof, M. and Rietkerk. 2007b. High solar radiation hinders tree regeneration above the alpine treeline in northern Ecuador. Plant Ecology 191:33-45.

Baumann, F. 1988 Geographische Verbreitung und Ökologie südamerikanischer Hochgebirgspflanzen. Beitrag zur Rekonstruktion der quartären Vegetationsgeschichte der Anden. PhD Thesis, Zurich University.

Behling $\mathrm{H}_{\text {., }}$ and $\mathrm{H}$. Hooghiemstra. 2000. Holocene Amazon rain forest-savanna dynamics and climatic implications: high resolution pollen record Laguna Loma Linda in eastern Colombia. Journal of Quaternary Science 15: 687-695.

Behling H., and V. Pillar. 2007. Late Quaternary vegetation, biodiversity and fire dynamics on the southern Brazilian highland and their implication for conservation and management of modern Araucaria forest and grassland ecosystems. Philosophical Transactions of the Royal Society B 362:243-251.

Bendix J., P. Fabian, and R. Rollenbeck. 2004. Gradients of fog and rain in a tropical montane cloud forest of southern Ecuador and its chemical composition. Proceedings 3rd International Conference on Fog, Fog Collection and Dew, 11-15 Oct. 2004, Cape Town ZA.

Brehm G., J. Homeier, K. Fiedler. 2003. Beta diversity of geometrid moths (Lepidoptera: Geometridae) in an Andean montane rainforest. Diversity and Distributions 9:351-366.

Brehm G., J. Homeier, K. Fiedler, I. Kottke, J. Illig, N. Nöske, F. Werner, and S.-W. Breckle. 2008. Are mountain rain forests in southern Ecuador a hotspot of biodiversity? Limited knowledge and diverging patterns. Pages 15-23 in: E. Beck, J. Bendix, I. Kottke, F. Makeschin, R. Mosandl, editors. Gradients in a Tropical Mountain Ecosystem of Ecuador. Ecological Studies 198, Springer, Berlin. 
Brunschön C., and H. Behling. 2009. Late Quaternary vegetation, fire and climate history reconstructed from two cores at Cerro Toledo, Podocarpus National Park, southeastern Ecuadorian Andes. Quaternary Research 72:388-399.

Brunschön C., and H. Behling. 2010. Reconstruction and visualization of upper forest line and vegetation changes in the Andean depression region of southeastern Ecuador since the last glacial maximum - a multi-site synthesis. Review of Palaeobotany and Palynology 163:139-152.

Bush, M. 2002. Distributional change and conservation on the Andean flank: a paleoecological perspective. Global Ecology and Biogeography 11:463-473.

Colwell, R., G. Brehm, C. Cardelús, A. Gilman, and J. Longino. 2008. Global warming, elevational range shifts, and lowland biotic attrition in the wet tropics. Science 322:258-261.

Coûteaux, M., L. Sarmiento, P. Bottner, D. Acevedo, and J. Thiéry. 2002. Decomposition of standard plant material along an altitudinal transect $(65-3968 \mathrm{~m})$ in the tropical Andes. Soil Biology and Biochemistry 34:69-78.

Emck, P. 2007. A Climatology of South Ecuador. With Special Focus on the Major Andean Ridge as Atlantic-Pacific Climate Divide. PhD thesis. Erlangen-Nuremberg University.

Emck P., and M. Richter. 2008. An upper threshold of enhanced global shortwave irradiance in the troposphere derived from field measurements in tropical mountains. Journal of Applied Meteorology and Climatology 47:2828-2845.

Epstein H., I. Burke, and W. Lauenroth. 2002. Regional patterns of decomposition and primary production rates in the US. Great Plains Ecology 83:20-327.

Fægri, K., and J. Iversen. 1989. Textbook of pollen analysis. $4^{\text {th }}$, edited by K. Fægri, P. Kaland, and K. Krzywinski. John Wiley \& Sons, Chichester.

Fjeldså, J. 1994. Geographical patterns for relict and young species of birds in Africa and South America and implications for conservation priorities. Biodiversity and Conservation 3:207226.

Fries, A., R. Rollenbeck, T. Nauß, T. Peters, and J. Bendix. 2012. Near surface air humidity in a megadiverse Andean mountain ecosystem of southern Ecuador and its regionalization. Agricultural and Forest Meteorology 152: 17-30.

Gentry, A. 1982. Neotropical floristic diversity: Phytogeographical connections between Central and South America, Pleistocene climatic fluctuations, or an accident of the Andean orogeny? Annals of the Missouri Botanical Garden 69:557-593.

Gotelli, N. 2004. A taxonomic wish-list for community ecology. Philosophical Transactions of the Royal Society of London Series B 359:585-597.

Hansen, B., D. Rodbell, G. Seltzer, B. Leon, K. Young, M. Abbott. 2003. Late-glacial and Holocene vegetational history from two sites in the western Cordillera of southwestern Ecuador. Palaeogeography, Palaeoclimatology, Palaeoecology 194:79-108.

Herzog, S., R. Martínez, P. Jørgensen, H. Tiessen. 2011. Climate Change and Biodiversity in the Tropical Andes. Inter-American Institute for Global Change Research (IAI) and Scientific Committee on Problems of the Environment (SCOPE), Paris.

Hole, D., K. Young, A. Seimon, C. Gomez, D. Hoffmann, K. Schutze, S. Sanchez, D. Muchoney, H. Grau, E. Ramirez. 2011. Adaptive management for biodiversity conservation under climate change - a tropical Andean perspective. Pages 19-46, in: S. Herzog, R. Martínez, P. Jørgensen, and $\mathrm{H}$. Tiessen, editors. Climate change effects on the biodiversity of the tropical Andes: an assessment of the status of scientific knowledge. Inter-American Institute of Global Change Research (IAI) and Scientific Committee on Problems of the Environment (SCOPE), Paris.

Holtmeier, F. 2003. Mountain timberlines. Ecology, patchiness and dynamics. Advances in Global Research 14. Kluwer, Doordrecht.

Illig, J., R. Langel, R. Norton, S. Scheu, and M. Maraun. 2005. Where are the decomposers? Uncovering the soil food web of a tropical montane rain forest in southern Ecuador using stable isotopes $\left({ }^{15} \mathrm{~N}\right)$. Journal of Tropical Ecology 21:589-593. 
IPCC. 2007.Climate Change 2007: The Physical Science Basis. Contribution of Working Group I to the Fourth Assessment Report of the Intergovernmental Panel on Climate Change. Cambridge University Press, Cambridge.

Isbell, F., V. Calcagno, A. Hector, J. Connolly, W. Harpole, P. Reich, M. Scherer-Lorenzen, B. Schmid, D. Tilman, J. van Ruijven, A. Weigelt, B. Wilsey., E. Zavaleta, and M. Loreau. 2011. High plant diversity is needed to maintain ecosystem services. Nature 477:199-203.

Ise, T., A. Dunn, S. Wofsy, and P. Moorcroft. 2008. High sensitivity of peat decomposition to climate change through water-table feedback. Nature Geoscience 1:763-766.

Jantz ,N., and H. Behling. 2012. A Holocene environmental record reflecting vegetation, climate, and fire variability at the Páramo of Quimsacocha, southwestern Ecuadorian Andes. Vegetation History and Archaeobotany 21:169-185.

Kessler, M. 1995. Polylepis-Wälder Boliviens: Taxa, Ökologie, Verbreitung und Geschichte. Dissertationes Botanicae 246.

Kessler, M. 2002. The elevational gradient of Andean plant endemism: varying influences of taxon-specific traits and topography at different taxonomic levels. Journal of Biogeography 29:1159-1165.

Kessler, M., and S. Hohnwald. 1998. Bodentemperaturen innerhalb und außerhalb bewaldeter und unbewaldeter Blockhalden in den bolivianischen Hochanden. Ein Test der Hypothese von Walter \& Medina (1969). Erdkunde 52:54-62.

Körner, C. 2007. Climatic treelines: Conventions, global patterns, causes. Erdkunde 61: 316-324.

Krashevska, V., M. Bonkowski, M. Maraun, and S. Scheu. 2007. Testate amoebae (Protista) of an elevational gradient in the tropical mountain rain forest of Ecuador. Pedobiologia 51:319331.

Krashevska, V., M. Maraun, L. Ruess, and S. Scheu. 2010. Micro- and macroscale changes in density and diversity of testate amoebae of tropical montane rain forests of southern Ecuador. Acta Protozoologica 49:17-28.

Krashevska, V., D. Sandmann, M. Maraun, and S. Scheu. 2012. Consequences of exclusion of precipitation on microorganisms and microbial consumers in montane tropical rain forests. Oecologia, 170:1067-1076.

Ließ, M. 2010 Soil-landscape modelling in an Andean mountain forest region in southern Ecuador. $\mathrm{PhD}$ thesis, University of Bayreuth.

Maestre, F., J. Quero, N. Gotelli, A. Escudero, V. Ochoa, M. Delgado-Baquerizo, M. García-Gómez , M. Bowker, S. Soliveres, C. Escolar, P. García-Palacios, M. Berdugo, E. Valencia, B. Gozalo, A. Gallardo, L. Aguilera, T. Arredondo, J. Blones, B. Boeken, D. Bran, A. Conceição, O. Cabrera, M. Chaieb, M. Derak, D. Eldridge, C. Espinosa, A. Florentino, J. Gaitán, M. Gatica, W. Ghiloufi , S. Gómez-González, J. Gutiérrez, R. Hernández, X. Huang, E. Huber-Sannwald, M. Jankju, M. Miriti J. Monerris, R. Mau, E. Morici, K. Naseri, A. Ospina, V. Polo, A. Prina, E. Pucheta, D. Ramírez-Collantes, R. Romão, M. Tighe, C. Torres-Díaz, J. Val, J. Veiga, D. Wang, and E. Zaady E. 2012. Plant species richness and ecosystem multifunctionality in global drylands. Science 335:214-218.

Malhi,Y., J. Roberts, R. Betts, T. Killeen, W. Li, and C. Nobre C. 2008. Climate change, deforestation, and the fate of the Amazon. Science 319:169-172.

Marengo, J., J. Pabón, A. Díaz, G. Rosas, G. Ávalos, E. Montealegre, M. Villacis, S. Solman, and M. Rojas. Climate Change: Evidence and Future Scenarios for the Andean Region. Pages 110127 in S. Herzog, R. Martínez, P. Jørgensen, and H. Tiessen, editors. Climate change effects on the biodiversity of the tropical Andes: an assessment of the status of scientific knowledge. Inter-American Institute of Global Change Research (IAI) and Scientific Committee on Problems of the Environment (SCOPE), Paris.

Mayle, F., Burbridge, R., and T. Killeen. 2000. Millennial-scale dynamics of southern Amazonian rain forests. Science 290:2291-2294.

Missouri Botanical Garden. 2011. Tropicos database: www.tropicos.org, accessed 11.8.2011. 
Mutke, J., and W. Barthlott. 2005. Patterns of vascular plant diversity at continental to global scales. in: I. Friis, H. Balslev, editors. Plant diversity and complexity patterns - local, regional and global dimensions. Biologiske Skrifter 55:521-537.

Myers, N., R. Mittermeier, C. Mittermeier , G. Da Fonseca, and J. Kent. 2000. Biodiversity hotspots for conservation priorities. Nature 403:853-858.

Niemann, H., and H. Behling. 2008. Late Quaternary vegetation, climate and fire dynamics inferred from the El Tiro record in the southeastern Ecuadorian Andes. Journal of Quaternary Science 23:203-212.

Niemann, H., and H. Behling. 2009. Late Pleistocene and Holocene environmental change inferred from the Cocha Caranga sediment and soil records in the southeastern Ecuadorian Andes. Palaeogeography, Palaeoclimatology, Palaeoecology 276:1-14.

Niemann, H., T. Haberzettl, and H. Behling. 2009. Holocene climate variability and vegetation dynamics inferred from the (11700 cal. yr BP) Laguna Rabadilla de Vaca sediment record, southeastern Ecuadorian Andes. The Holocene 19:307-316.

Nöske, N., N. Hilt, F. Werner, G. Brehm, K. Fiedler, H. Sipman, and R. Gradstein. 2008. Disturbance effects on epiphytes and moths in a montane forest in Ecuador. Basic and Applied Ecology 9:4-12.

Orlóci, L., V. Pillar, M. Anand, H. Behling. 2002. Some interesting characteristics of the vegetation process. Community Ecology 3:125-146.

Paduano, G., M. Bush, P. Baker, S. Fritz, G. Seltzer. 2003. A vegetation and fire history of Lake Titicaca since the Last Glacial Maximum. Palaeogeography, Palaeoclimatology, Palaeoecology 194:259-279.

Peters, T. 2009. Struktur und ökologische Merkmale der oberen Waldgrenze in der Andinen Depression. PhD Thesis. University Erlangen-Nuremberg.

Pillar, V. 2001 SYNCSA; application program for multivariate analysis of trait-based community data. UFRGS, Departamento de Ecologia, Porto Alegre.

Richter, M., Diertl, K., P. Emck, T. Peters, and E. Beck. 2009. Reasons for an outstanding plant diversity in the tropical Andes of Southern Ecuador. Landscape Online 12:1-35.

Rollenbeck, R., J. Bendix. 2011. Rainfall distribution in the Andes of southern Ecuador derived from blending weather radar data and meteorological field observations. Atmospheric Research 99/1:277-289.

Schönborn, W. 1973. Humusform und Testaceen-Besatz. Pedobiologia 13:353-360.

Sleigh, M. 1989. Protozoa and other protists. Edward Arnold, London.

ter Braak, C., and P. Šmilauer. 2002. CANOCO Reference manual and CanoDraw for Windows User's Guide: Software for Canonical Community Ordination (version 4.5). Microcomputer Power, Ithaka.

Tobón, C., L. Köhler, K. Frumau, L. Bruijnzeel, R. Burkhard, S. Schmid. 2010. Water dynamics of epiphytic vegetation in a lower montane cloud forest: fog interception, storage, and evaporation. Pages 261-267 in L. Bruijnzeel, F. Scatena, L. Hamilton, editors. Tropical montane cloud forests: science for conservation and management. Cambridge University Press, Cambridge.

Vitousek, P., D. Turner, W. Parton, and R. Sanford. 1994. Litter decomposition on the Mauna Loa matrix: patterns, mechanisms, and models. Ecology 75:418-429.

Weng, C., M. Bush, A. Chepstow-Lusty. 2004. Holocene changes of Andean alder (Alnus acuminata) in highland Ecuador and Peru. Journal of Quaternary Science 19:685-691.

Weng, C., M. Bush, J. Curtis, A. Kolata, T. Dillehay, M. Binford. 2006. Deglaciation and holocene climate change in the western Peruvian Andes. Quaternary Research 66:87-96.

Werner, F. 2011. Reduced growth and survival of vascular epiphytes on isolated remnant trees in a recent tropical montane forest clear-cut. Basic and Applied Ecology 12:172-181.

Werner, F., R. Gradstein. 2008. Seedling establishment of vascular epiphytes on isolated and enclosed forest trees in an Andean landscape, Ecuador. Biodiversity and Conservation 17:3195-3207. 
Wilkinson, D., E. Mitchell. 2010. Testate amoebae and nutrient cycling with particular reference to soil. Geomicrobiology Journal 27:520-533.

Zhang, Y., H. Chen, and P. Reich. 2012. Forest productivity increases with evenness, species richness and trait variation: a global meta-analysis. Journal of Ecology 100:742-749. 


\section{CHAPTER 7}

\section{Synthesis}

The chapters of this dissertation contribute to an enhanced knowledge of Quaternary palaeoecology of the South Ecuadorian Andes. The analyses of new sites, together with the comprehensive overview of broader patterns in vegetation, climate and fire history of the North/Central Andes and detailed analysis of modern pollen rain - vegetation relationships across a large altitudinal gradient provide a large pool of information for a comprehensive view on vegetation development of a highly species-rich region that is unique for a Neotropical mountain ecosystem. Furthermore, new methodological approaches and the evaluation of methods commonly used in tropical palynology give way to a broader understanding of the complex mechanisms that have to be considered when working with palynological data. In the following sections, main research outcomes of this thesis are summarized, discussed and synthesized. Needs as well as to possibilities for further research are addressed and an outline is given to general conclusions and implications.

\subsection{Discussion of main research outcomes}

\subsubsection{Holocene vegetation, climate, human impact and fire history at key sites in South Ecuador}

The Holocene environmental history of South Ecuador was the main topic of the chapters 2 and 6 of this thesis. These palaeoecological studies helped to elucidate important questions about Holocene environmental changes in the South Ecuadorian Andes.

The palaeoenvironmental record of the Tres Lagunas region of the Quimsacocha volcanic basin reveals changing environmental conditions since the early Holocene at ca. 8000 cal. yr BP (chapter 2) and is an important dataset that helps to detect regional environmental dynamics of the tropical Andes region.

One of the important palaeoecological research issues in tropical South America is the early to mid-Holocene dry period. In some regions, it seemed to be a phase of severe environmental change (Abbott et al. 2003, De Toledo and Bush 2007, Mayle and Power 2008, Rodríguez and Behling 2012), whereas in others, the effect was less pronounced to invisible (Brunschön and Behling 2009, see other examples in Carré et al. 2012). At the Quimsacocha volcanic basin, changes in sediment structure, as well as highly elevated pollen and charcoal concentrations and increases in percentages of pollen taxa of dry grassland vegetation indicate the prevalence of less 
humid conditions between ca. 7700 and $2250 \mathrm{cal}$. yr BP. However, a hiatus in the record seems to be evident during this phase. Nevertheless, it is known that warm and dry conditions can enhance peat decomposition and thus prevent sediment accumulation (Coûteaux et al. 2002, Ise et al. 2008). Also, it has been assumed that sediment hiatuses can be indicators of a complete dryingout of the sediment (De Toledo and Bush 2007). We cannot date the length of the dry period with absolute certainty and it is difficult to estimate its strength, but our result gives new evidence for the extension of the dry phase across parts of the tropical Andes from Bolivia (Abbott et al. 2003), Peru (Hillyer et al. 2009, Valencia et al. 2010) and Ecuador (Rodríguez and Behling 2012) to Colombia (Marchant et al. 2002).

As the charcoal record points out, fires have played a role in the Quimsacocha volcanic basin since the early Holocene. This may have been caused by either growing human impact during early Holocene times or higher flammability of the vegetation due to a drier climate.

The late Holocene at the Páramo of Quimsacocha is marked by a change to cooler and moister conditions at around 2200 cal. yr BP, as the record is dominated by pollen of Plantago rigida type for the next ca. 1000 years. Then, an increase in abundance of pollen of Eryngium type, Alnus and Huperzia points to a drier and possibly more disturbed habitat.

Afterwards, a colder and moister period is recorded. This time span could correspond to the little Ice Age and is marked by higher values of taxa growing under cold and moist conditions (Isoëtes, Valeriana, Lamiaceae, Gentianella and Caryophyllaceae). The little ice age is known to have affected large parts of Europe from ca. 1350-1850 A.D. (Wanner et al. 2008). Our findings correspond well with studies in other regions of the Andes (Thompson et al. 1986, Rabatel et al. 2005, Polissar et al. 2006).

Subsequently, the modern conditions become established. The upper forest line rises to its present position, and an increase in taxa showing anthropogenic influence, such as Pinus and Zea mays point to a higher human impact during the last ca. 200 years. Generally, as can be seen by the analysis of the rate of change of different ecosystems (Chapter 6$)$, the late Holocene was/is a period of highest change velocity since the beginning of the Holocene, which points to increasing ecosystem instability throughout the South Ecuadorian Andes. Also, time trajectories show that changes throughout the Holocene are often non-directional and confuse. This may be due to a mixed signal of the vegetation which is subjected not only to a changing climate but also to higher human impact during this period.

\subsubsection{Vegetation/modern pollen rain relationship at different vegetation types of South Ecuador}

The analysis of three years of modern pollen rain in the southern Ecuadorian Andes elucidate many aspects of pollen dispersal mechanisms and patterns in the modern pollen rain - vegetation 
relationship that help to improve palaeoecological reconstruction by the means of pollen analysis. A very important result for palynology, as well as for ecology in general, demonstrates that in the region of South Ecuador, taxonomic surrogacy of plant species to families is feasible without losing too much systematic information. As correlation between plant family and species data was high with $R=0.81$ and $p<0.001$, a linear relationship of $y=1.5 x+3.95$ for plant species against family diversity could be determined (chapter 3). Even though the current classification system of Linnean ranks is highly heterogeneous due to various historic and contemporary ideas that lead to the sometimes arbitrary assignation of species to specific taxonomic units (Bertrand et al. 2006), it has been shown before that spatial patterns in ß-diversity can be detected by using family data (Terlizzi et al. 2008). However, we have shown that working with families as taxonomic units can facilitate the work of both ecologists and palynologists, as it is a good approach for the detection of distribution patterns and minimizes the risk of false species assignments in a highly biodiverse region. It remains to be clarified whether this method is a good approach for estimations of pollen type richness, as the evenness-problem (Odgaard 1999, 2001) remains to be addressed in this matter.

Regarding detected taxa distribution patterns in data of different vegetation types in the Podocarpus National Park area, it can be stated that plant and pollen data were able to capture major differences along the altitudinal gradient (chapter 3). Whereas abundance-based plant data at family level was slightly more precise, pollen and tree datasets showed a lack of precision when looking at just diversity data for the premontane and lower montane forest. Generally, a distinction between different slope positions is difficult when looking at either plant or pollen data at family level. These results fit in well with the findings of other authors working with pollen data, who suggest an "assemblage-approach", a combination of diversity and abundance data, to be best for the differentiation of pollen rain patterns from floristically comparatively similar vegetation types (Gosling et al. 2009). This is supported by the pollen accumulation rate data, which were collected during a period of three years for premontane forest, lower montane forest and upper montane forest (chapter 5). It gave a good estimation of the pollen productivity of the different forest types and the average productivity of the most abundant pollen taxa and showed that some taxa, such as Melastomataceae/Combreatceae, Weinmannia, Myrsine, Alchornea/Alchorneopsis and Clusia are no good indicators for one forest type, as they produce similar amounts of pollen grains in different vegetation types. This is a very important result which should be taken into account for future palaeoecological research, as it calls the frequently used strategy of palaeoecologists into question, which is creating sums for groups of taxa to make statements about past vegetation developments on a larger scale. 
The comparison of pollen accumulation rate data for three years show furthermore that the spatial component of pollen trap data is more important than the time component, i.e. taxa composition varies more among two traps that may only be a few meters apart from each other than among trap data obtained during different years. Specific phenological patterns could not be observed during the studied period, but it is hard to estimate whether this is due to a lacking resolution in the pollen data or due to little variation in phenology in the studied area, as plant ecological data on this matter are scarce.

The pollen family diversity pattern along the altitudinal gradient from the premontane forest at $1000 \mathrm{~m}$ a.s.l. to the upper montane forest at ca. $3000 \mathrm{~m}$ a.s.l. is hump-shaped, with highest taxa richness occurring at the lower montane forest (ca. $2000 \mathrm{~m}$ a.s.l., chapter 3 ). It thus behaves similar to the tree diversity pattern. The overall taxa numbers at family level are similar, but higher taxa numbers can be recorded for the plant family data at the premontane and lower montane sites, whereas pollen taxa have a higher family richness in the upper montane forest sites. This is probably due to a higher evenness in the pollen data of the upper montane forest (i.e. less taxa which produce very high amounts of pollen grains) and to stronger wind fields in the upper crest region of the Andes. As in other studies dealing with neotropial modern pollen rain (Gosling et al. 2009, Niemann et al. 2010), high percentages of external pollen taxa are found at all altitudes, which suggests high rates of long-distance transport, especially by anemophilous taxa which produce a large amount of very light pollen grains throughout the area. However, a transect study covering a large area and more detailed data about wind patterns are necessary to estimate the source areas. Generally, pollen derives from further upslope in premontane forest and lower montane forest, whereas data from the upper montane forest and the páramo show an upslope transport of pollen from lower to higher altitudes.

Typically over-represented taxa at all altitudes are Moraceae/Urticaceae, Melastomataceae, Hedyosmum and Weinmannia. However, representation of a taxon can vary with the medium used for modern pollen rain collection (chapter 4). In soil samples, taxa with a fragile exine, such as Moraceae/Urticaceae, Lauraceae, Acalypha, Cecropia and Cyperaceae, are less represented than in the typically used traps in the Neotropics, the modified Oldfield trap and the Behling trap. The trap types show different sensibilities to drought and radiation. Whereas the modified Oldfield trap is not as withstanding in the páramo region, where it disintegrated after one year in the field, both trap types assessed produced equally good results in the forest.

\subsection{Open questions and uncertainties}

The analyses carried out in this thesis leave room for many open questions and uncertainties that indicate a strong need for further study on the subject. 
Obviously, the two parts of the thesis, i.e. patterns in past and present palynological data, have to be linked more closely in order to explore the existing data in a more quantitative way.

Nevertheless, the study of modern pollen rain patterns is an important step towards a better interpretation of pollen records under the light of the patterns and processes observed in the modern pollen rain data until now. For example, the "assemblage-approach" (Gosling et al. 2009) of combining pollen data in terms of diversity and abundance patterns in order to find thresholds of vegetation change should be applied on a more quantitative scale.

However, the modern pollen rain data still lack precision on the spatial scale, as it was obtained punctually for each vegetation type without considering an altitudinal transect, as no vegetation data was obtainable. Therefore, the data reflect very well the conditions in a given vegetation type (as it covers many replications) but not its changes along the altitudinal gradient. Even though Niemann et al. (2009) have done a similar study along a transect from ca. 1900 to ca. 3200 $\mathrm{m}$ a.s.I., one year of pollen collection is not enough to detect whether phenological variability may be important during periods of stronger seasonality, e.g. during periods of El Niño, and detailed vegetation surveys are needed to understand pollen distribution patterns on a larger scale. An ideal modern pollen rain study would involve a large altitudinal transect of vegetation plots where each individual plant species could be relocated on a map with all physiological details. Also, climate data, such as precipitation, wind speeds and directions throughout the seasons and at different times of the day and temperature data should be recorded to assess the present pollen taxa - vegetation and present pollen taxa - climate relationships on a more detailed scale which would make quantitative estimations about past climate conditions based on pollen data feasible. Furthermore, a more frequent pollen trap exchange for a period of at least five years could give more accurate results concerning temporal variability of pollen dispersion. Furthermore, more emphasis should be put on the improvement of existing trap types.

Concerning the palaeoecological analyses, many issues need to be addressed.

The mid-Holocene dry event has been shown to be important throughout many regions of South America, but especially in the central Andes, signals remain contradicting (Carré et al. 2012). Even though it is known that a change of orbital parameters caused the dry event as such, it is still not fully resolved which triggering mechanisms were responsible (Berger and Loutre 1991, Clement et al. 2000).

On a larger scale, many uncertainties about the mid-Holocene dry phase need to be clarified, as the timing and length of the event across the tropical Andes, which has been described as timetransgressive shift of the period by some authors (Abbott et al. 2003, Bush et al. 2005) remains largely undetermined. Furthermore, it is not clear which extension or severity the mid-Holocene dry event had. 
It remains unclear, which part of the south Ecuadorian Andes was subjected to a severe dry phase during the mid-Holocene. At present, the eastern tropical Andes within the Andean depression are influenced by exceptionally irregular precipitation patterns which are largely controlled by the easterly trade winds coming from the Amazon basin (Rollenbeck and Bendix 2011). However, the complex mechanisms of Andean weather and climate phenomena make forecasts impossible today, and even less is known about their past. Thus, it is at this point very difficult to state whether we cannot see changes in vegetation composition towards a much drier climate at midHolocene times in large parts of the South-Eastern Ecuadorian Andes because there were none or because the ecosystems analysed are more resilient to precipitation changes. Also, a regionally different development, namely the upward-migration of the upper forest line in some regions, such as El Tiro, takes place until the mid-Holocene at ca. 6000 cal. yr BP (see chapter 6 and Niemann and Behling, 2008). Even though this directional ecosystem change which can be detected by multivariate data analyses (see Fig. 2 in Chapter 6) can be interpreted as a warming signal, it is unclear whether or not it was related to drier conditions. More proxies might help to clarify this question.

For the fire-record, which shows burning since early Holocene times, it remains unclear, if these fires were of local or regional origin. As burning grass páramo does not produce woody but only herb charcoal, it is difficult to find bigger charred pieces that would suggest a local influence of fire even today, where we know fires are frequently lit by people in the very same region (own observation). Even though it is possible that fires can be lit naturally by lightning, many páramos have frequently been burned by humans to increase the nutritional value of the forage for livestock (Ramsay and Oxley 1996). We do not know when this practise started and whether it is possible that humans might have burned páramo areas since the early Holocene for the reason mentioned before or others, for example to create hunting corridors. Archaeological findings of the area are scarce and cannot give enough direct evidence for strong human interferences. Thus, the reason for high charcoal concentrations in early to mid-Holocene palaeoenvironmental archives of the Andes remains doubtful, as a dry climate may have made the vegetation more inflammable.

Nevertheless, a complexity of human-environment interactions in the Holocene of the Central Andes is apparent and new archives may help to disentangle the assumptions to find generalizable principles (Contreras 2010).

\subsection{General implications and perspectives}

The results obtained give a good overview of different temporal and spatial patterns in pollen data of the South Ecuadorian Andes. With this thesis, a further step towards a comprehensive 
interpretation on palaeoenvironmental conditions during the past is taken, as it creates a basis for a carefully elaborated view on possible ecosystem dynamics in the light of global change and nature conservation issues. The results show, that the ecosystems of the South Ecuadorian Andes can in their natural state, generally cope well with even severe ecosystem changes, e.g. long dry and warm phases. In the study region of the Quimsacocha volcanic basin, marked vegetation changes did not take place since the early Holocene, as there are no changes in the overall composition but only in abundance patterns of plants.

However, the rate of change analysis of many sites across the South Ecuadorian Andes showed that nearly all sites were subjected to high velocities of change in taxa composition during the late Holocene. Due to human impact through increased use of fire, livestock grazing and the plantation of pine and Eucalyptus for the creation of forested sites in the páramo, the ecosystems seem to become more and more unbalanced and less resilient to face climate change.

This may have severe impacts that harm ecosystem dynamics in the future. A return to moderate human impact is therefore necessary to ensure the maintenance of important ecosystem services when ecosystems face global change, e.g. water retention capacity and food source. This is important, as climate predictions estimate that temperature rise will be faster at higher altitudes, varying from $2-6^{\circ} \mathrm{C}$ during a period of 100 years (1990-1999 to 2090-2099, depending on the model), and considering that the highlands constitute the most important water sources for the population of the tropical Andean countries (Bradley 2006).

The alarming expectations of climate change in the tropical Andes underline a great need of further palaeoenvironmental studies in this area.

Three years of modern pollen rain collection at selected sites in four surveyed vegetation types can only be a first step towards a more quantitative view on the topic. The analyses cannot capture the whole spatial and temporal dynamics of different environmental factors influencing pollen dispersal in this highly species-rich region. Also, any palaeoecological analysis gives only a small impression about a past environment and its changes throughout time and even a range of analyses may not be able to capture the full picture of past environmental dynamics for one region. However, the steady growth of data increases our knowledge about patterns and processes that help to understand the underlying mechanisms of why ecosystems changed in this way or the other and how these changes happen. We should not forget that palynology is one of the best tools we have to understand the landscapes we live in and form continuously, as it makes hidden patterns and processes of long-term ecosystem dynamics visible. It can help to predict ecosystem response in future climate and conservation scenarios, but moreover it also shows us nature as it is, was and should be conserved in all its complexity and beauty. 


\subsection{References}

Abbott, M., B. Wolfe, A. Wolfe, G. Seltzer, R. Aravena, B. Mark, P. Polissar, D. Rodbell, H. Rowe, and M. Vuille. 2003. Holocene paleohydrology and glacial history of the central Andes using multiproxy lake sediment studies. Palaeogeography, Palaeoclimatology, Palaeoecology 194:123-138.

Berger, A., and M. Loutre. 1991. Insolation values for the climate of the last 10 million years. Quaternary Science Reviews 10:297-317.

Bertrand, Y., F. Pleijel, and G. Rouse. 2006. Taxonomic surrogacy in biodiversity assessments, and the meaning of Linnaean ranks. Systematics and Biodiversity 4:149-159.

Bradley, R. 2006. CLIMATE CHANGE: Threats to Water Supplies in the Tropical Andes. Science 312:1755-1756.

Brunschön, C., and H. Behling. 2009. Late Quaternary vegetation, fire and climate history reconstructed from two cores at Cerro Toledo, Podocarpus National Park, southeastern Ecuadorian Andes. Quaternary Research 72:388-399.

Bush, M. B., B. Hansen, D. Rodbell, G. Seltzer, K. Young, B. León, M. Abbott, M. Silman, and W. Gosling. 2005. A 17 000-year history of Andean climate and vegetation change from Laguna de Chochos, Peru. Journal of Quaternary Science 20:703-714.

Carré, M., M. Azzoug, I. Bentaleb, B. M. Chase, M. Fontugne, D. Jackson, M.-P. Ledru, A. Maldonado, J. P. Sachs, and A. J. Schauer. 2012. Mid-Holocene mean climate in the south eastern Pacific and its influence on South America. Quaternary International 253:55-66.

Clement, A., R. Seager, and M. Cane. 2000. Suppression of El Niño during the Mid-Holocene by changes in the Earth's orbit. Paleoceanography 15:731.

Contreras, D. A. 2010. Landscape and Environment: Insights from the Prehispanic Central Andes. Journal of Archaeological Research 18:241-288.

Coûteaux, M., L. Sarmiento, P. Bottner, D. Acevedo, and J. Thiéry. 2002. Decomposition of standard plant material along an altitudinal transect $(65-3968 \mathrm{~m})$ in the tropical Andes. Soil Biology and Biochemistry 34:69-78.

Gosling, W., F. Mayle, N. Tate, and T. Killeen. 2009. Differentiation between Neotropical rainforest, dry forest, and savannah ecosystems by their modern pollen spectra and implications for the fossil pollen record. Review of Palaeobotany and Palynology 153:7085.

Hillyer, R., B. Valencia, M. Bush, M. Silman, and M. Steinitzkannan. 2009. A 24,700-yr paleolimnological history from the Peruvian Andes. Quaternary Research 71:71-82.

Ise, T., A. Dunn, S. Wofsy, and P. Moorcroft. 2008. High sensitivity of peat decomposition to climate change through water-table feedback. Nature Geoscience 1:763-766.

Marchant, R., H. Behling, J.-C. Berrio, A. Cleef, J. Duivenvoorden, H. Hooghiemstra, P. Kuhry, B. Melief, E. Schreve-Brinkman, B. Van Geel, T. Van der Hammen, G. Van Reenen, and M. Wille. 2002. Pollen-based biome reconstructions for Colombia at 3000, 6000, 9000, 12 000,15000 and $1800014 \mathrm{C}$ yr ago: Late Quaternary tropical vegetation dynamics. Journal of Quaternary Science 17:113-129.

Mayle, F., and M. Power. 2008. Impact of a drier Early-Mid-Holocene climate upon Amazonian forests. Philosophical Transactions of the Royal Society B: Biological Sciences 363:18291838.

Niemann, H., and H. Behling. 2008. Late Quaternary vegetation, climate and fire dynamics inferred from the El Tiro record in the southeastern Ecuadorian Andes. Journal of Quaternary Science 23:203-212.

Niemann, H., C. Brunschön, and H. Behling. 2010. Vegetation/modern pollen rain relationship along an altitudinal transect between 1920 and 3185ma.s.l. in the Podocarpus National Park region, southeastern Ecuadorian Andes. Review of Palaeobotany and Palynology 159:69-80. 
Odgaard, B. 2001. Palaeoecological perspectives on pattern and process in plant diversity and distribution adjustments: a comment on recent developments. Diversity and Distributions 7:197-201.

Odgaard, B. vad. 1999. Fossil pollen as a record of past biodiversity. Journal of Biogeography 26:717.

Polissar, P. J., M. Abbott, A. Wolfe, M. Bezada, V. Rull, and R. Bradley. 2006. Solar modulation of Little Ice Age climate in the tropical Andes. Proceedings of the National Academy of Sciences 103:8937-8942.

Rabatel, A., V. Jomelli, P. Naveau, B. Francou, and D. Grancher. 2005. Dating of Little Ice Age glacier fluctuations in the tropical Andes: Charquini glaciers, Bolivia, $16^{\circ} \mathrm{S}$. Comptes Rendus Geosciences 337:1311-1322.

Ramsay, P. M., and E. R. B. Oxley. 1996. Fire temperatures and postfire plant community dynamics in Ecuadorian grass paramo. Vegetatio 124:129-144.

Rodríguez, F., and H. Behling. 2012. Late Quaternary vegetation, climate and fire dynamics, and evidence of early to mid-Holocene Polylepis forests in the Jimbura region of the southernmost Ecuadorian Andes. Palaeogeography, Palaeoclimatology, Palaeoecology 350-352:247-257.

Rollenbeck, R., and J. Bendix. 2011. Rainfall distribution in the Andes of southern Ecuador derived from blending weather radar data and meteorological field observations. Atmospheric Research 99:277-289.

Terlizzi, A., M. Anderson, S. Bevilacqua, S. Fraschetti, M. Włodarska-Kowalczuk, and K. Ellingsen. 2008. Beta diversity and taxonomic sufficiency: Do higher-level taxa reflect heterogeneity in species composition? Diversity and Distributions 15:450-458.

Thompson, L., E. Mosley-Thompson, W. Dansgaard,, and P. Grootes. 1986. The Little Ice Age as Recorded in the Stratigraphy of the Tropical Quelccaya Ice Cap. Science 234:361-364.

De Toledo, M., and M. Bush. 2007. A mid-Holocene environmental change in Amazonian savannas. Journal of Biogeography 34:1313-1326.

Valencia, B., D. Urrego, M. Silman, and M. Bush. 2010. From ice age to modern: a record of landscape change in an Andean cloud forest. Journal of Biogeography 37:1637-1647.

Wanner, H., J. Beer, J. Butikofer, T. Crowley, U. Cubasch, J. Fluckiger, H. Goosse, M. Grosjean, F. Joos, and J. Kaplan. 2008. Mid- to Late Holocene climate change: an overview. Quaternary Science Reviews 27:1791-1828. 
Appendix 


\section{Appendix 1: Modern pollen rain studies across the Andes - An overview}

The table contains a compilation of modern pollen rain studies apart from the ones carried out in this thesis, sorted by country from North to South. Information is given about location, altitude, number of counted samples, reference study, studied vegetation type, type of material analysed, diagram type, calculation of AOU-values (Davis, 1984, see chapter 4 for a more detailed explanation), R-Values (see Davis 1963, Pearson and Prentice, 1981), type of Multivariate Data analysis (MVDA) applied, and other methods used for calibration of the modern pollen rain-vegetation relationships (see references mentioned for a more detailed explanation).

\begin{tabular}{|c|c|c|c|c|c|c|c|c|c|c|c|c|}
\hline Country & $\begin{array}{l}\text { Coordinates } \\
\text { (Lat) }\end{array}$ & $\begin{array}{l}\text { Coordinates } \\
\text { (Long) }\end{array}$ & $\begin{array}{l}\text { Altitude } \\
\text { (m a.s.I.) }\end{array}$ & $\begin{array}{l}\text { No. Of } \\
\text { samples }\end{array}$ & Reference & $\begin{array}{l}\text { Vegetation } \\
\text { studied }\end{array}$ & $\begin{array}{l}\text { Type of } \\
\text { sample }\end{array}$ & Diagram type & AOU & $\begin{array}{l}\text { R- } \\
\text { Val } \\
\text { ues }\end{array}$ & $\begin{array}{l}\text { MVD } \\
\text { A }\end{array}$ & Other \\
\hline Venezuela & $\sim 72-69^{\circ} \mathrm{W}$ & $\sim 10-7^{\circ} \mathrm{N}$ & $940-4765$ & 18 & $\begin{array}{l}\text { (Salgado- } \\
\text { Labouriau } \\
1979)\end{array}$ & $\begin{array}{l}\text { Mountain } \\
\text { forest and } \\
\text { Páramo }\end{array}$ & $\begin{array}{l}\text { Soil } \\
\text { samples }\end{array}$ & $\begin{array}{l}\text { Percentage, } \\
\text { (concentration) }\end{array}$ & --- & --- & --- & --- \\
\hline Venezuela & $\begin{array}{l}70^{\circ} 52^{\prime}- \\
70^{\circ} 42^{\prime} \mathrm{W}\end{array}$ & $8^{\circ} 52^{\prime}-8^{\circ} 46 \mathrm{~N}$ & $2300-4610$ & 50 & (Rull 2006) & $\begin{array}{l}\text { Mountain } \\
\text { forest and } \\
\text { Páramo }\end{array}$ & $\begin{array}{l}\text { Soil } \\
\text { samples }\end{array}$ & Percentage & --- & --- & DCA & $\begin{array}{l}\text { Altitudinal range } \\
\text { (weighted averaging), } \\
\text { HOF-models, WA-PLS } \\
\text { transfer functions }\end{array}$ \\
\hline Colombia & $\sim 75-72^{\circ} \mathrm{W}$ & $\sim 8-3^{\circ} \mathrm{N}$ & $300-3500$ & 177 & $\begin{array}{l}\text { (Grabandt } \\
\text { 1980) }\end{array}$ & $\begin{array}{l}\text { Mountain } \\
\text { forest }\end{array}$ & $\begin{array}{l}\text { Moss } \\
\text { samples }\end{array}$ & Percentage & $\begin{array}{l}--- \\
\end{array}$ & --- & --- & $T(v) / p$-values \\
\hline Colombia & $\sim 74-73^{\circ} \mathrm{W}$ & $\sim 12-10^{\circ} 50 \mathrm{~N}$ & $0-4300$ & 18 & $\begin{array}{l}\text { (Melief } \\
\text { 1984) }\end{array}$ & $\begin{array}{l}\text { Páramo, } \\
\text { mountain } \\
\text { forest, } \\
\text { premontan } \\
\text { e forest }\end{array}$ & $\begin{array}{l}\text { Moss } \\
\text { samples }\end{array}$ & Percentage & --- & Yes & --- & t/p-values \\
\hline Colombia & $75-76^{\circ} \mathrm{W}$ & $\begin{array}{l}4^{\circ} 93^{\prime}- \\
5^{\circ} 14^{\prime} \mathrm{N}\end{array}$ & $1150-3700$ & 28 & $\begin{array}{l}\text { (Rangel- } \\
\text { Ch. 2005) }\end{array}$ & $\begin{array}{l}\text { Mountain } \\
\text { forest }\end{array}$ & $\begin{array}{l}\text { Moss } \\
\text { samples }\end{array}$ & Percentage & $\mathrm{AOU}$ & --- & --- & $\begin{array}{l}T(v) / p \text {-values, MBV } \\
\text { values }\end{array}$ \\
\hline Colombia & $77-73^{\circ} \mathrm{W}$ & $\begin{array}{l}5^{\circ} 12^{\prime}- \\
4^{\circ} 10^{\prime} \mathrm{N}\end{array}$ & $300-4500$ & $20 * 48$ & $\begin{array}{l}\text { (Witte } \\
1994)\end{array}$ & $\begin{array}{l}\text { Mountain } \\
\text { forest }\end{array}$ & $\begin{array}{l}\text { Moss } \\
\text { samples }\end{array}$ & --- & --- & --- & --- & $\begin{array}{l}\text { Pollen-class rank vs. } \\
\text { vegetation-class } \\
\text { rank, Spearman rank } \\
\text { correlation, } \\
\text { probability per pollen }\end{array}$ \\
\hline
\end{tabular}




\begin{tabular}{|c|c|c|c|c|c|c|c|c|c|c|c|c|}
\hline Country & $\begin{array}{l}\text { Coordinates } \\
\text { (Lat) }\end{array}$ & $\begin{array}{l}\text { Coordinates } \\
\text { (Long) }\end{array}$ & $\begin{array}{l}\text { Altitude } \\
\text { (m a.s.l.) }\end{array}$ & $\begin{array}{l}\text { No. Of } \\
\text { samples }\end{array}$ & Reference & $\begin{array}{l}\text { Vegetation } \\
\text { studied }\end{array}$ & $\begin{array}{l}\text { Type of } \\
\text { sample }\end{array}$ & Diagram type & AOU & $\begin{array}{l}\text { R- } \\
\text { Val } \\
\text { ues } \\
\end{array}$ & $\begin{array}{l}\text { MVD } \\
\text { A }\end{array}$ & Other \\
\hline & & & & & & & & & & & & $\begin{array}{l}\text { class, climate } \\
\text { calibrations }\end{array}$ \\
\hline Ecuador & $77^{\circ} 43^{\prime} \mathrm{W}$ & $0^{\circ} 36^{\prime} \mathrm{N}$ & $3000-4000$ & $27 * 10$ & $\begin{array}{l}\text { (Olivera et } \\
\text { al. 2009) }\end{array}$ & $\begin{array}{l}\text { Mountain } \\
\text { forest, } \\
\text { Páramo }\end{array}$ & $\begin{array}{l}\text { Soil } \\
\text { samples, } \\
\text { Modified } \\
\text { Oldfield } \\
\text { traps, } \\
\text { moss } \\
\text { samples }\end{array}$ & Percentage, & A & & $\begin{array}{l}\text { RDA, } \\
\text { CA }\end{array}$ & $\begin{array}{l}\mathrm{t} / \mathrm{p} \text {-value evaluation } \\
\text { of representation }\end{array}$ \\
\hline Ecuador & $\begin{array}{l}78^{\circ} 37- \\
78^{\circ} 34^{\prime} \mathrm{W}\end{array}$ & $0^{\circ} 20^{\prime}-0^{\circ} 22^{\prime} \mathrm{S}$ & $3250-4070$ & 16 & $\begin{array}{l}\text { (Wille et } \\
\text { al. 2002) }\end{array}$ & $\begin{array}{l}\text { Mountain } \\
\text { forest, } \\
\text { Páramo, } \\
\text { Superpára } \\
\text { mo }\end{array}$ & $\begin{array}{l}\text { Moss } \\
\text { samples }\end{array}$ & Percentage & --- & --- & --- & --- \\
\hline Ecuador & $79^{\circ} 10^{\prime} \mathrm{W}$ & $2^{\circ} 45^{\prime} \mathrm{S}$ & $2700-4060$ & 13 & $\begin{array}{l}\text { (Hansen et } \\
\text { al. 2003) }\end{array}$ & $\begin{array}{l}\text { Mountain } \\
\text { forest and } \\
\text { Páramo }\end{array}$ & $\begin{array}{l}\text { Soil } \\
\text { samples, } \\
\text { moss } \\
\text { samples }\end{array}$ & $\begin{array}{l}\text { Percentage/ } \\
\text { concentration }\end{array}$ & --- & --- & --- & --- \\
\hline Ecuador & $79^{\circ} 4^{\prime} 25^{\prime \prime} W$ & $3^{\circ} 58^{\prime} 30^{\prime \prime} \mathrm{S}$ & $1800-3185$ & 41 & $\begin{array}{l}\text { (Niemann } \\
\text { et al. } \\
\text { 2010) }\end{array}$ & $\begin{array}{l}\text { Lower } \\
\text { mountain } \\
\text { forest, } \\
\text { upper } \\
\text { mountain } \\
\text { forest, } \\
\text { Subpáram } \\
\text { o } \\
\end{array}$ & $\begin{array}{l}\text { Behling } \\
\text { traps } \\
\text { (1 year) }\end{array}$ & percentage & --- & --- & DCA & --- \\
\hline Peru & $\begin{array}{l}76^{\circ} 13^{\prime}- \\
68^{\circ} 59^{\prime} \mathrm{W}\end{array}$ & $\begin{array}{l}6^{\circ} 42^{\prime}- \\
13^{\circ} 57^{\prime} \mathrm{S}\end{array}$ & $750-3570$ & 49 & $\begin{array}{l}\text { (Urrego et } \\
\text { al. 2011) }\end{array}$ & $\begin{array}{l}\text { Mountain } \\
\text { forest }\end{array}$ & $\begin{array}{l}\text { Moss } \\
\text { samples }\end{array}$ & percentage & & & DCA & $\begin{array}{l}\text { PDFs elevation vs. } \\
\text { pollen, basal area, } \\
\text { abundance, } \\
\text { herbarium } \\
\text { collections }\end{array}$ \\
\hline Peru & $77^{\circ} 35^{\prime} \mathrm{W}$ & $7^{\circ} 43^{\prime} \mathrm{S}$ & $2800-3800$ & 17 & (Hansen & Mountain & Soil & percentage & --- & --- & --- & --- \\
\hline
\end{tabular}




\begin{tabular}{|c|c|c|c|c|c|c|c|c|c|c|c|c|}
\hline Country & $\begin{array}{l}\text { Coordinates } \\
\text { (Lat) }\end{array}$ & $\begin{array}{l}\text { Coordinates } \\
\text { (Long) }\end{array}$ & $\begin{array}{l}\text { Altitude } \\
\text { (m a.s.l.) }\end{array}$ & $\begin{array}{l}\text { No. Of } \\
\text { samples }\end{array}$ & Reference & $\begin{array}{l}\text { Vegetation } \\
\text { studied }\end{array}$ & $\begin{array}{l}\text { Type of } \\
\text { sample }\end{array}$ & Diagram type & AOU & $\begin{array}{l}R- \\
\text { Val } \\
\text { ues }\end{array}$ & $\begin{array}{l}\text { MVD } \\
\text { A }\end{array}$ & Other \\
\hline & & & & & $\begin{array}{l}\text { and } \\
\text { Rodbell } \\
\text { 1995) }\end{array}$ & $\begin{array}{l}\text { forest and } \\
\text { Páramo }\end{array}$ & $\begin{array}{l}\text { samples, } \\
\text { Moss } \\
\text { samples }\end{array}$ & & & & & \\
\hline Peru & $\begin{array}{l}72^{\circ} 50- \\
72^{\circ} 20 \mathrm{~W}\end{array}$ & $\begin{array}{l}15^{\circ} 20- \\
15^{\circ} 605\end{array}$ & $1870-5255$ & 24 & $\begin{array}{l}\text { (Kuentz et } \\
\text { al. 2007) }\end{array}$ & $\begin{array}{l}\text { Desert, } \\
\text { mountain } \\
\text { steppe, } \\
\text { puna, } \\
\text { mountain } \\
\text { rain forest, }\end{array}$ & $\begin{array}{l}\text { Soil } \\
\text { samples }\end{array}$ & percentage & --- & --- & PCA & --- \\
\hline Peru & $71^{\circ} \mathrm{W}$ & $12^{\circ} \mathrm{S}$ & $340-3530$ & 44 & $\begin{array}{l}\text { (Weng et } \\
\text { al. 2004) }\end{array}$ & $\begin{array}{l}\text { Sub-puna, } \\
\text { mountain } \\
\text { forest, } \\
\text { premontan } \\
\text { e forest, } \\
\text { swamp }\end{array}$ & $\begin{array}{l}\text { Soil } \\
\text { samples, } \\
\text { Moss } \\
\text { samples }\end{array}$ & $\begin{array}{l}\text { Percentage, } \\
\text { concentration }\end{array}$ & --- & --- & $\overline{D C A}$ & $\begin{array}{l}\text { Blind pollen zone } \\
\text { classification test }\end{array}$ \\
\hline Peru/Bolivia & $72-66^{\circ} \mathrm{W}$ & $13-21^{\circ} \mathrm{S}$ & $230-4680$ & 40 & $\begin{array}{l}\text { (Reese and } \\
\text { Kam-Biu } \\
\text { 2005) }\end{array}$ & $\begin{array}{l}\text { Puna, } \\
\text { Subpuna, } \\
\text { Desert, } \\
\text { mountain } \\
\text { forest }\end{array}$ & $\begin{array}{l}\text { Soil } \\
\text { samples }\end{array}$ & percentage & --- & --- & LDA & --- \\
\hline Bolivia & $\begin{array}{l}68^{\circ} 84^{\prime}- \\
64^{\circ} 20^{\prime} W\end{array}$ & $\begin{array}{l}13^{\circ} 06^{\prime}- \\
21^{\circ} 74^{\prime} \mathrm{S}\end{array}$ & $167-4700$ & 40 & $\begin{array}{l}\text { (Ortuño et } \\
\text { al. 2011) }\end{array}$ & $\begin{array}{l}9 \text { Bolivian } \\
\text { ecoregions }\end{array}$ & $\begin{array}{l}\text { Soil } \\
\text { samples }\end{array}$ & Percentage & --- & --- & COIA & $\begin{array}{l}\text { Correlation with } \\
\text { elevation, } \\
\text { precipitation, annual } \\
\text { temperature }\end{array}$ \\
\hline
\end{tabular}




\section{References}

Davis, M. 1963. On the theory of pollen analysis. American Journal of Science 261:897-912.

Davis, O. 1984. Pollen frequencies reflect vegetation patterns in a great basin (U.S.A.) mountain range. Review of Palaeobotany and Palynology 40:295-315.

Grabandt, R. 1980. Pollen rain in relation to arboreal vegetation in the Colombian Cordillera Oriental. Review of Palaeobotany and Palynology 29:65-147.

Hansen, B., D. Rodbell, G. Seltzer, B. Leon, K. Young, and M. Abbott. 2003. Late-glacial and Holocene vegetational history from two sites in the western Cordillera of southwestern Ecuador. Palaeogeography, Palaeoclimatology, Palaeoecology 194:79-108.

Hansen, B., and D. T. Rodbell. 1995. A Late-Glacial/Holocene Pollen Record from the Eastern Andes of Northern Peru. Quaternary Research 44:216-227.

Kuentz, A., A. G. de Mera, M.-P. Ledru, and J.-C. Thouret. 2007. Phytogeographical data and modern pollen rain of the puna belt in southern Peru (Nevado Coropuna, Western Cordillera). Journal of Biogeography 34:1762-1776.

Melief, A. 1984. Comparison of vegetation and pollen rain on the Buritaca-la Cumbre transect (Sierra Nevada de Santa Marta, Colombia). Pages 547-559 Studies on tropical andean ecosystems 2. J. Cramer (Borntraeger), Berlin-Stuttgart.

Niemann, H., C. Brunschön, and H. Behling. 2010. Vegetation/modern pollen rain relationship along an altitudinal transect between 1920 and 3185ma.s.l. in the Podocarpus National Park region, southeastern Ecuadorian Andes. Review of Palaeobotany and Palynology 159:69-80.

Olivera, M. M., J. F. Duivenvoorden, and H. Hooghiemstra. 2009. Pollen rain and pollen representation across a forest-páramo ecotone in northern Ecuador. Review of Palaeobotany and Palynology 157:285-300.

Ortuño, T., M.-P. Ledru, R. Cheddadi, A. Kuentz, C. Favier, and S. Beck. 2011. Modern pollen rain, vegetation and climate in Bolivian ecoregions. Review of Palaeobotany and Palynology 165:61-74.

Parsons, R., and I. Prentice. 1981. Statistical approaches to R-values and the pollen- vegetation relationship. Review of Palaeobotany and Palynology 32:127-152.

Rangel-Ch., J. 2005. Lluvia de polen a lo largo de los transectos del macizo del Tatamá. Pages 711755 La Cordillera Occidental colombiana- Transecto de Tatamá. Cramer/Bornträger, Berlin-Stuttgart.

Reese, C., and L. Kam-Biu. 2005. A modern pollen rain study from the central Andes region of South America. Journal of Biogeography:709-718.

Rull, V. 2006. A high mountain pollen-altitude calibration set for palaeoclimatic use in the tropical Andes. The Holocene 16:105-117.

Salgado-Labouriau, M. L. 1979. Modern pollen deposition in the Venezuelan Andes. Grana 18:5368.

Urrego, D., M. Silman, A. Correa-Metrio, and M. Bush. 2011. Pollen-vegetation relationships along steep climatic gradients in western Amazonia. Journal of Vegetation Science 22:795-806.

Weng, C., M. B. Bush, and M. R. Silman. 2004. An analysis of modern pollen rain on an elevational gradient in southern Peru. Journal of Tropical Ecology 20:113-124.

Wille, M., H. Hooghiemstra, R. Hofstede, J. Fehse, and J. Sevink. 2002. Upper forest line reconstruction in a deforested area in northern Ecuador based on pollen and vegetation analysis. Journal of Tropical Ecology 18:409-440.

Witte, H. 1994. Present and past vegetation and climate in the Northern Andes (Cordillera Central, Colombia): A quantitative approach. PhD thesis, University of Amsterdam. 


\section{Appendix 2: Representation of taxa in Andean modern pollen rain studies}

One purpose of modern pollen rain studies is to determine dispersal characteristics of pollen taxa that can be used for a more quantitative reconstruction of palaeoecological conditions. Of course this is very dependent on local vegetation processes and present biotic and abiotic factors a region is exposed to. Pollen/vegetation relationships have been studied in a variety of different ecosystems and altitudes across the tropical Andes, each with different climatic and edaphic characteristics that control plant abundance and pollen dispersal. Also, one pollen taxon usually consists of more than one species or genus, making direct comparisons between different regions complicated, as each species/genus has its own ecological properties and dispersal power. Nevertheless, for many taxa, some general patterns are visible, which can help to gain a comprehensive overview and to interpret palaeodata at least in qualitative terms. Here, a compilation of ecological information on taxa derived from a variety of modern pollen rain studies across the tropical Andes region is shown.

The pollen and spore taxa mentioned here have each been recorded in at least three independent modern pollen rain studies across the Andes.

Abbreviations are as follows: LLF - Lowland forest, TMF - tropical mountain forest (in general terms), PMF - premontane forest, LMF - lower mountain forest, UMF- upper mountain forest, PAR - Páramo, PDF - Probability density function

\section{Acalypha (Euphorbiaceae)}

Irregular represented ${ }^{1}$ to over-represented ${ }^{2-4}$, over-represented in $\mathrm{UMF}^{5}$, pollen found in vegetation zones from $L M F$ to $\mathrm{PAR}^{1-5}$, regional pollen distribution with slight effect on interpretation of pollen signal ${ }^{2}$, upslope transport with easterly winds ${ }^{3}$

\section{Alchornea (Euphorbiaceae)}

Over-represented ${ }^{1,2,5,6}$ to mostly over-represented ${ }^{2}$, irregularly represented in UMF ${ }^{5}$, overrepresented in $\mathrm{PMF}$ and $\mathrm{PAR}^{4}$, well represented in $\mathrm{LMF}^{4}$, regional pollen distribution with at least slight effect on the interpretation of the pollen signal ${ }^{2}$, no correspondence between plot and pollen abundance probability density functions (PDFs) in Peru ${ }^{7}$, pollen found in vegetation zones from LLF to $P A R^{1,2,4,5}$ 


\section{Alnus (Betulaceae)}

Over-represented ${ }^{5,4,6,8,9}$, high dispersion power ${ }^{8}$ with large amounts of pollen produced ${ }^{6}$, pollen found in vegetation zones from LMF to $\mathrm{PAR}^{4-9}$, strong correlation between plot and pollen abundance PDFs ${ }^{7}$

\section{Apiaceaee}

Over-represented with regional pollen distribution with effect on interpretation of pollen signal in $U_{M F^{2}}$ to under-represented ${ }^{5}$ or irregularly represented ${ }^{4}$ in PAR, precipitation ${ }^{10}$ : (437.9)876.8(2159.4) $\mathrm{mm} / \mathrm{a}$, temperature ${ }^{10}: 2.8(6) 9.2^{\circ} \mathrm{C}$

\section{Arecaceae}

Under-represented as often flowering above the canopy ${ }^{1}$ to irregularly represented with regional pollen distribution but low production without effect on the interpretation of the pollen signal ${ }^{2}$ to well represented ${ }^{2,4}$ and occurring with high concentrations in the $\mathrm{PMF}^{2}$, temperature ${ }^{10}$ : $(13.2) \mathbf{1 6 . 5}(20.2)^{\circ} \mathrm{C}$

\section{Asteraceae}

Well represented to over-represented in $\mathrm{UMF}^{2,5}$ and $\mathrm{LMF}^{2}$, over-represented in $\mathrm{PMF}^{2,4}$, underrepresented $^{5}$ to well represented in PAR $^{4,5}$, irregularly ${ }^{1}$ or over-represented ${ }^{10}$ in TMF and PAR, from low dispersion power and local distribution ${ }^{8}$, to relatively large quantities of pollen produced $^{6}$ and "easy" pollen distribution with high concentrations possible ${ }^{2}$, LLF to PAR $\mathrm{R}^{1,2,4-6,8,10}$, temperature, precipitation and frost day occurrence estimations varying for different taxa: precipitation $^{10}$ : Espeletia hartwegiana 550.5(758.5)1206.6 mm/a, Baccharis 437.9(732.9)1206.6 $\mathrm{mm} / \mathrm{a}$; temperature ${ }^{10}$ : Baccharis $2.7(6.1) 9.5^{\circ} \mathrm{C}$, Conyza $2.2(5.4) 8.5^{\circ} \mathrm{C}$, Diplostephium $1.3(5) 8.8^{\circ} \mathrm{C}$, Gnaphalium $1.9(5) 8^{\circ} \mathrm{C}, 55.4-208.5$ frost days, Gynoxys $2.5(5.8) 9^{\circ} \mathrm{C}$, Munnozia $4.1(7.4) 10.7^{\circ} \mathrm{C}$, Senecio $2.5(5.7) 8.8^{\circ} \mathrm{C}$; frost days ${ }^{10}$ : Conyza $55.4-208.5$

\section{Cecropia (Urticaceae)}

Over-represented in $L M F$ to $P A R^{1,2}$, over-represented in UMF and $\mathrm{PAR}^{3,4}$, under-represented in $\mathrm{UMF}^{5}$, regional pollen distribution with effect on interpretation of pollen signal ${ }^{2}$, due to upslope transport of pollen ${ }^{3}$ and background-effects ${ }^{1}$, pollen found from LMF to PAR ${ }^{1-5}$. 


\section{Clethra (Clethraceae)}

Over-represented in $\mathrm{UMF}^{4}$ and SUB to $\mathrm{PAR}^{3}$ to under-represented in $\mathrm{UMF}^{5}$, upslope transport of pollen $^{3}$, strong correlation between plot and pollen abundance PDFs, distribution peak at ca. 2000-3000 m a.s.l. ${ }^{7}$, pollen found from LMF-PAR ${ }^{3-5}$

\section{Clusiaceae}

Under- $\left({ }^{1}\right.$ for Clusia in TMF to PAR, ${ }^{5}$ for Clusia flavifolia in UMF), well-represented in PMF-LMF ${ }^{2}$, irregularly represented from $\mathrm{PMF}^{2}$ to $\mathrm{UMF}^{2,4}$ or over-represented in $\mathrm{UMF}^{2}$, not strictly reflecting tree distribution ${ }^{6}$, precipitation $\left({ }^{10}\right.$ for Clusia): 533.6(1461.2)3033.3 mm/a

\section{Cyatheaceae}

Irregularly represented in $\mathrm{UMF}^{5}$ to over-represented in $\mathrm{TMF}$ and $\mathrm{PAR}^{1}$, long-distance transport possible and spore production copious ${ }^{6}$, LMF to PAR $^{1,5,6}$, precipitation $^{10}: 724.7(1396.8) 3033.3$ $\mathrm{mm} / \mathrm{a}$

\section{Cyperaceae}

Under-represented in $\mathrm{PAR}^{5}$ to well-represented in $T M F$ to $\mathrm{PAR}^{1}$ and $\mathrm{PAR}^{4}, \mathrm{TMF}$ to $\mathrm{PAR}^{1,4,5}$

\section{Ericaceae}

Under-represented in TMF to $\mathrm{PAR}^{1}$ and $\mathrm{PAR}^{5}$, irregularly represented in $\mathrm{UMF}^{5}$ and $\mathrm{PAR}^{4}$, frequently represented with small amounts of pollen ${ }^{6}, \mathrm{LMF}_{\text {to }} \mathrm{PAR}^{1,4,5}$, temperature, precipitation and frost day occurrence estimations varying for different taxa: precipitation ${ }^{10}$ : Pernettya 437.9(698.6)1139.1 mm/a, Gaultheria 612.9(836.3)1168.2mm/a, temperature ${ }^{10}$ : Pernettya 2.2(5.1) $8^{\circ} \mathrm{C}$, Gaultheria $3.4(6.7) 9.9^{\circ} \mathrm{C}$

\section{Gentianaceae}

Sometimes under-represented or slightly over-represented ${ }^{10}$, under-represented to well represented in $\mathrm{PAR}^{5}$, low dispersion power ${ }^{8}, \mathrm{LMF}$ to $\mathrm{PAR}^{5,8}$

\section{Geraniaceae}

Under-represented in $\mathrm{PAR}^{5}$ with low dispersion power ${ }^{8}$, mostly $\mathrm{PAR}^{5}$, temperature ${ }^{10}: 1.3(4.5) 7.6^{\circ} \mathrm{C}$

Hedyosmum (Chloranthaceae)Over-represented in all vegetation zones ${ }^{1,2,4-6,8-11}$, never underrepresented $^{10}$, moderate dispersion power ${ }^{8}$, abundant pollen producer ${ }^{6}$, "easy" pollen 
distribution with effect on interpretation of pollen signal ${ }^{2}$, strong correlation between plot and pollen abundance PDFs, peak at ca. $2000 \mathrm{~m}$ a.s.l., bimodal basal area PDF ${ }^{7}$, LLF to PAR ${ }^{1,2,4-6,8-11}$

\section{Hypericum (Hypericaceae)}

Slightly over-represented but sometimes under-represented ${ }^{10}$ to irregularly represented in the $\mathrm{PAR}^{4,5}$, well represented or over-represented in the $\mathrm{UMF}^{5}, \mathrm{UMF}^{5}$ to $\mathrm{PAR}^{4,5}$, precipitation 437.9(783.1)1206.6 mm/a $\mathrm{a}^{10}$, temperature ${ }^{10}: 2.6(5.6) 8.5^{\circ} \mathrm{C}$, frost days ${ }^{10}: 55.4-208.5$

\section{Ilex (Aquifoliaceae)}

Under-represented in $\mathrm{TMF}$ to $\mathrm{PAR}^{1,6}$ and $\mathrm{UMF}^{4,5}$, well represented in $\mathrm{UMF}^{4}$ to over-represented in $\mathrm{PMF}^{2,4}$ and $\mathrm{LMF}$ to $\mathrm{UMF}^{2}$, strong correlation between plot and pollen abundance PDFs, peak abundance at ca. $2000 \mathrm{~m}$ a.s. $\mathrm{I}^{7}, \mathrm{LMF}$ to $\mathrm{PAR}^{1,4-7}$

\section{Jamesonia (Pteridaceae)}

Over-represented $L M F$ to $\mathrm{PAR}^{1}$ and $\mathrm{UMF}^{5}$ to irregularly represented in $\mathrm{PAR}^{5}$, high local spore producer $^{1}$, low dispersion power ${ }^{8}$, LMF to $\mathrm{PAR}^{1,5,8}$

\section{Melastomataceae}

Under-represented in $\mathrm{PMF}$ and $\mathrm{LLF}^{1}$, well represented in $\mathrm{PMF}$ to $\mathrm{UMF}^{2,4}$ and $\mathrm{PAR}^{4}$, irregularly represented ${ }^{5}$ or over-represented ${ }^{1,6}$, low dispersion power $^{8}$, low pollen producers with regional

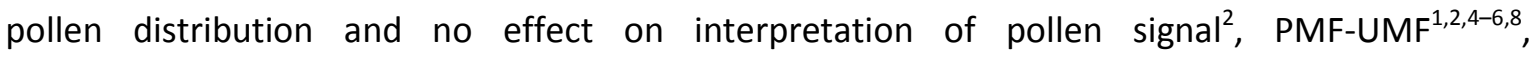
temperature ${ }^{10}:$ Miconia $10.7(14) 17.5^{\circ} \mathrm{C}$

\section{Moraceae/Urticaceae}

Over-represented TMF to $\mathrm{PAR}^{1}, \mathrm{UMF}^{3}$ and $\mathrm{PAR}^{3,4}$ irregularly represented TMF to $\mathrm{PAR}{ }^{10}$ and $\mathrm{UMF}^{5}$, "easy" pollen distribution with possible effects on interpretation of pollen signal ${ }^{2}$, upslope transport with strong easterly winds ${ }^{3}$, PMF-PAR $^{1-5}$ precipitation $511(\mathbf{1 0 8 7 . 8}) 1691.9 \mathrm{~mm} / \mathrm{a}$, temperature ${ }^{10}: 14.4(\mathbf{1 7 . 7}) 21.5^{\circ} \mathrm{C}$

\section{Myrica (Myricaceae)}

Well-represented in $\mathrm{UMF}^{2}$, over-represented TMF-PAR ${ }^{1,2}, \mathrm{UMF}^{5}, \mathrm{LMF}^{4}$ and $\mathrm{PAR}^{4}$, irregularly represented LMF-PAR ${ }^{6}$, low dispersion power ${ }^{8}$, regional to "easy" pollen distribution with effect on interpretation of pollen signal, occurring with high concentration ${ }^{2}$, PMF-PAR $^{1,2,4-6,8}$ 


\section{Myrsine (Primulaceae)}

Under-represented in UMF and $\mathrm{PAR}^{5}$ to well represented in $\mathrm{UMF}^{4}$, over-represented in $\mathrm{LMF}$ and $\mathrm{PAR}^{4}$ or Irregularly represented in $\mathrm{UMF}^{2}$ and $L L F-\mathrm{PAR}^{1}$, frequently represented with various amounts $^{6}$, low dispersion power ${ }^{8}$, strong correlation between plot and pollen abundance PDFs, abundance peak at ca. $3000 \mathrm{~m}$ a.s.I. ${ }^{7}$, LLF to $\mathrm{PAR}^{1,4-8}$

\section{Myrtaceae}

Under-represented in TMF to $P A R^{1}$ and UMF-PAR ${ }^{5}$ to slightly over-represented in $L M F$ to $P A R^{6}$ or irregularly represented in $\mathrm{LMF}^{4}$, reflecting local and adjacent vegetation conditions ${ }^{1}, \mathrm{PMF}$ to $\mathrm{PAR}^{1,4-6}$, temperature ${ }^{10}$ : Eugenia $15.5(\mathbf{1 8 . 5}) 21.6^{\circ} \mathrm{C}$, Myrtaceae $18.1(\mathbf{2 2 . 2}) 27.4^{\circ} \mathrm{C}$

\section{Oreopanax (Araliaceae)}

Under-represented TMF to $\mathrm{PAR}^{1}$ and to irregularly represented ${ }^{10}$ or well represented in $\mathrm{UMF}^{4}$, UMF to $\mathrm{PAR}^{1,4}$, temperature ${ }^{10}: 10.3(\mathbf{1 3} .6) 17^{\circ} \mathrm{C}$

\section{Poaceae}

Under-represented in $\mathrm{PAR}^{1,5}$, well-represented in $\mathrm{PAR}^{4,5}$, irregularly represented in $\mathrm{UMF}^{5}$ or overrepresented in $\mathrm{TMF}^{4,5}$, reflecting local and adjacent conditions with low upwards dispersion power $^{8}$, "easy" pollen distribution with effect on interpretation of pollen signal ${ }^{2}$, taxon occurring with high concentrations ${ }^{2}, P M F$ to $P R^{1,2,4,5,8}$, precipitation ${ }^{10}$ : Bromus $437.9(599.2) 907$ mm/a, temperature ${ }^{10}$ : Calamagrostis $1.5(4.6) 7.7^{\circ} \mathrm{C}$, frost days ${ }^{10}:$ Poa $161-267.5$

\section{Podocarpaceae}

Over-represented in TMF to $\mathrm{PAR}^{1,2} \mathrm{PAR}^{4,5,8,11}$ and $\mathrm{UMF}^{11}$, well represented in $\mathrm{UMF}^{4}$ or irregularly representedin $\mathrm{UMF}^{5}$, moderate dispersion power ${ }^{8}$, long-distance transport common ${ }^{1}$, regional to "easy" pollen distribution with effect on interpretation of pollen signal ${ }^{2}$, taxon occurring with high concentrations ${ }^{2}$, strong correlation between plot and pollen abundance PDFs with peak at ca. 2000 m a.s.l. $^{7}$

\section{Prunus type (Rosaceae)}

Under-represented in $\mathrm{UMF}^{5}$ to irregularly represented in $\mathrm{PMF}$ to $\mathrm{LMF}^{2}$, low pollen producers with regional pollen distribution and no effect on interpretation of pollen signal ${ }^{2}, \mathrm{PMF}^{2}$ to $\mathrm{UMF}^{1,5}$

\section{Puya (Bromeliaceae)}

Under-represented in $\mathrm{UMF}^{9}$ to $\mathrm{PAR}^{5,9}$, reflecting local and adjacent conditions ${ }^{1}$, $\mathrm{LMF}$ to $\mathrm{PAR}^{1,5,9}$ 


\section{Quercus (Fagaceae)}

Well represented in $\mathrm{UMF}^{5}$ to over-represented in $\mathrm{UMF}^{5}$ and $\mathrm{LMF}$ to $\mathrm{PAR}^{6}$ or irregularly represented in PMF to $\mathrm{LMF}^{2}$, low percentage found up-or downslope from Quercus-forest zone ${ }^{6}$, low pollen producers with regional pollen distribution and no effect on interpretation of pollen signal ${ }^{2}$, PMF to PAR $^{2,5,6}$, precipitation $^{10}$ : Quercus humboldtii $1578.7(\mathbf{2 3 8 9 . 4 )} 3033.3 \mathrm{~mm} / \mathrm{a}$

\section{Symplocos (Symplocaceae)}

Well represented to under-represented in $\mathrm{UMF}^{4}$, irregularly represented in $\mathrm{UMF}^{5}$ or overrepresented in $\mathrm{PMF}^{2}$ or $\mathrm{TMF}^{1}$, $\mathrm{PMF}$ to $\mathrm{PAR}^{1,2,4,5}$

\section{Valeriana (Valerianaceae)}

Under-represented in $\mathrm{UMF}^{5}$ to well-represented in $\mathrm{PAR}^{5}$ or irregularly represented in $\mathrm{PAR}^{4}, \mathrm{UMF}$ to $\operatorname{PAR}^{4,5}$, temperature ${ }^{10}: 4.1(7.5) 10.9^{\circ} \mathrm{C}$

\section{Weinmannia (Cunoniaceae)}

Under-represented in $\mathrm{TMF}$ to $\mathrm{PAR}^{1,6}$ and $\mathrm{UMF}^{5}$ well represented in UMF and partly $\mathrm{LMF}^{4}$ or overrepresented in LMF and $\mathrm{PAR}^{4}$, reliable indication of plant presence ${ }^{6}$, if pollen value $>10 \%$ locally abundant ${ }^{1}$, strong correlation between plot and pollen abundance PDFs with peak at ca. $3000 \mathrm{~m}$ a.s. . $^{7}, \mathrm{LMF}^{1,4-7}$ to PAR; temperature ${ }^{10}: 7.5(\mathbf{1 0} .5) 13.5^{\circ} \mathrm{C}$

\section{References}

1. Melief, A. 1984. Comparison of vegetation and pollen rain on the Buritaca-la Cumbre transect (Sierra Nevada de Santa Marta, Colombia). Studies on tropical andean ecosystems, 2:547-559

2. Rangel-Ch., J. 2005. Lluvia de polen a lo largo de los transectos del macizo del Tatamá. La Cordillera Occidental colombiana- Transecto de Tatamá 6:711-755.

3. Niemann, H., C. Brunschön, and H. Behling, H. 2010. Vegetation/modern pollen rain relationship along an altitudinal transect between 1920 and 3185 ma.s.l. in the Podocarpus National Park region, southeastern Ecuadorian Andes. Review of Palaeobotany and Palynology 159:69-80.

4. Jantz, N., H. Behling, J. Homeier, S. León-Yánez, and A. Moscoso 2013. Trapping pollen in the tropics - Comparing modern pollen rain spectra of different pollen traps and surface samples across Andean vegetation zones. DOI:10.1016/j.revpalbo.2013.01.011.

5. Olivera, M., J. Duivenvoorden, and H. Hooghiemstra. 2009. Pollen rain and pollen representation across a forest-páramo ecotone in northern Ecuador. Review of Palaeobotany and Palynology 157: 285-300.

6. Grabandt, R. 1980. Pollen rain in relation to arboreal vegetation in the Colombian Cordillera Oriental. Review of Palaeobotany and Palynology 29:65-147.

7. Urrego, D., M. Silman, A. Correa-Metrio, and M. Bush. 2011. Pollen-vegetation relationships along steep climatic gradients in western Amazonia. Journal of Vegetation Science 22:795-806. 
8. Salgado-Labouriau, M. 1979. Modern pollen deposition in the Venezuelan Andes. Grana 18:53-68.

9. Hansen, B., D. Rodbell, G. Seltzer, B. Leon, K. Young, and M. Abbott. 2003. Late-glacial and Holocene vegetational history from two sites in the western Cordillera of southwestern Ecuador. Palaeogeography, Palaeoclimatology, Palaeoecology 194:79-108.

10. Witte, H. 1994. Present and past vegetation and climate in the Northern Andes (Cordillera Central, Colombia): A quantitative approach. PhD-thesis. University of Amsterdam.

11. Hansen, B., and D. Rodbell. 1995. A Late-Glacial/Holocene Pollen Record from the Eastern Andes of Northern Peru. Quaternary Research 44:216-227. 


\section{Appendix 3: List of all Matrix-plots with}

\section{topographic information}

\begin{tabular}{|c|c|c|c|c|c|c|c|}
\hline Site & PlotID & Slope & $\begin{array}{l}\text { Exposition } \\
\text { cp }\end{array}$ & $\begin{array}{l}\text { UTM } \\
\text { CoordX }\end{array}$ & $\begin{array}{l}\text { UTM } \\
\text { CoordY }\end{array}$ & $\begin{array}{l}\text { Geocoordinate } \\
\text { M a.s.I }\end{array}$ & $\begin{array}{c}\text { Topographic } \\
\text { position }\end{array}$ \\
\hline Cajanuma & Ca_US1 & 35 & $E$ & 702155 & 9545631 & .2891 & upper slope \\
\hline Cajanuma & Ca_US2 & 35 & ENE & 702160 & 9545656 & 2885 & upper slope \\
\hline Cajanuma & Ca_US3 & 30 & ENE & 702192 & 9545644 & 2869 & upper slope \\
\hline Cajanuma & Ca_US4 & 30 & W & 701986 & 9545651 & 2886 & upper slope \\
\hline Cajanuma & Ca_US5 & 45 & WSW & 702012 & 9545649 & 2890 & upper slope \\
\hline Cajanuma & Ca_US6 & 30 & NNW & 702016 & 9545684 & 2893 & upper slope \\
\hline Cajanuma & Ca_MS1 & 40 & ENE & 702243 & 9545574 & 2859 & mid slope \\
\hline Cajanuma & Ca_MS2 & 20 & ENE & 702200 & 9545607 & 2872 & mid slope \\
\hline Cajanuma & Ca_MS3 & 25 & ENE & 702260 & 9545591 & 2844 & mid slope \\
\hline Cajanuma & Ca_MS4 & 20 & w & 702595 & 9545043 & 2900 & mid slope \\
\hline Cajanuma & Ca_MS5 & 40 & WSW & 702577 & 9545019 & 2885 & mid slope \\
\hline Cajanuma & Ca_MS6 & 40 & sW & 702562 & 9544970 & 2875 & mid slope \\
\hline Cajanuma & Ca_LS1 & 15 & NNE & 702367 & 9545630 & 2818 & lower slope \\
\hline Cajanuma & $\mathrm{Ca}$ _LS2 & 15 & $\mathrm{~N}$ & 702375 & 9545609 & 2805 & lower slope \\
\hline Cajanuma & Ca_LS3 & 20 & NNE & 702308 & 9545658 & 2798 & lower slope \\
\hline Cajanuma & Ca_LS4 & 30 & NNW & 702017 & 9545590 & 2865 & lower slope \\
\hline Cajanuma & Ca_LS5 & 15 & NW & 701963 & 9545639 & 2878 & lower slope \\
\hline Cajanuma & Ca_LS6 & 15 & NNW & 701966 & 9545616 & 2880 & lower slope \\
\hline Bombuscaro & Bo_US1 & 0 & & 725696 & 9545001 & 1075 & upper slope \\
\hline Bombuscaro & Bo_US2 & 35 & NNW & 725703 & 9544970 & 1066 & upper slope \\
\hline Bombuscaro & Bo_US3 & 0 & & 725729 & 9544990 & 1072 & upper slope \\
\hline Bombuscaro & Bo_US4 & 25 & SE & 724474 & 9544210 & 1268 & upper slope \\
\hline Bombuscaro & Bo_US5 & 20 & SE & 724491 & 9544205 & 1257 & upper slope \\
\hline Bombuscaro & Bo_US6 & 15 & SE & 724502 & 9544174 & 1266 & upper slope \\
\hline Bombuscaro & Bo_MS1 & 30 & $E$ & 725575 & 9544917 & 1132 & mid slope \\
\hline Bombuscaro & Bo_MS2 & 40 & SSW & 725315 & 9544605 & 1069 & mid slope \\
\hline Bombuscaro & Bo_MS3 & 40 & SSE & 725090 & 9544389 & 1049 & mids \\
\hline Bombuscaro & Bo_MS4 & 35 & ESE & & & 1120 & mid slope \\
\hline Bombuscaro & Bo_MS5 & 40 & sW & & & 1140 & mid slope \\
\hline Bombuscaro & Bo_MS6 & 30 & $\mathrm{E}$ & 724584 & 9544015 & 1129 & mid slope \\
\hline Bombuscaro & Bo_LS1 & 35 & SSE & 725565 & 9544713 & 1020 & lower slope \\
\hline Bombuscaro & Bo_LS2 & 30 & $\mathrm{~S}$ & 725544 & 9544705 & 1026 & lower slope \\
\hline Bombuscaro & Bo_LS3 & 35 & ssw & 725457 & 9544734 & 1046 & lower slope \\
\hline Bombuscaro & Bo_LS4 & 20 & ESE & 724804 & 9544145 & 1054 & lower slope \\
\hline Bombuscaro & Bo_LS5 & 20 & SE & 724763 & 9544137 & 1056 & lower slope \\
\hline Bombuscaro & Bo_LS6 & 25 & $\mathrm{E}$ & 724773 & 9544089 & 1044 & lower slope \\
\hline San Francisco & SF_US1 & 20 & NW & 713721 & 9560455 & 2002 & upper slope \\
\hline San Francisco & SF_US2 & 20 & $\mathrm{~N}$ & 713726 & 9560391 & 2026 & upper slope \\
\hline San Francisco & SF_US3 & 30 & Wsw & 713666 & 9560143 & 2089 & upper slope \\
\hline San Francisco & SF_US4 & 30 & $\mathrm{NE}$ & 714040 & 9560321 & 2063 & upper slope \\
\hline
\end{tabular}




$\begin{array}{cccccccc}\text { Site } & \text { PlotID } & \text { Slope } & \text { cp } & \text { CoordX } & \text { CoordY } & \text { M a.s.I } & \begin{array}{c}\text { Exposition } \\ \text { UTM }\end{array} \\ \text { San Francisco } & \text { SF_US5 } & 25 & \text { NNE } & 714028 & 9560354 & 2054 & \text { upper slope } \\ \text { San Francisco } & \text { SF_US6 } & 30 & \text { ENE } & 714029 & 9560383 & 2039 & \text { upper slope } \\ \text { San Francisco } & \text { SF_L1 } & 40 & \text { NW } & 713648 & 9560242 & 2034 & \text { mid slope } \\ \text { San Francisco } & \text { SF_L2 } & 45 & \text { N } & 713975 & 9560524 & 1950 & \text { mid slope } \\ \text { San Francisco } & \text { SF_L3 } & 50 & \text { NW } & 713955 & 9560415 & 2027 & \text { mid slope } \\ \text { San Francisco } & \text { SF_L4 } & 30 & \text { NNE } & 714146 & 9560480 & 1927 & \text { mid slope } \\ \text { San Francisco } & \text { SF_L5 } & 45 & \text { NE } & 714115 & 9560429 & 1971 & \text { mid slope } \\ \text { San Francisco } & \text { SF_L6 } & 35 & \text { N } & 714123 & 9560342 & 2020 & \text { mid slope } \\ \text { San Francisco } & \text { SF_LS1 } & 35 & \text { N } & 713688 & 9560235 & 2039 & \text { lower slope } \\ \text { San Francisco } & \text { SF_LS2 } & 35 & \text { N } & 713655 & 9560307 & 1993 & \text { lower slope } \\ \text { San Francisco } & \text { SF_LS3 } & 35 & & & & 2010 & \text { lower slope } \\ \text { San Francisco } & \text { SF_LS4 } & 30 & & 714170 & 9560505 & 1913 & \text { lower slope } \\ \text { San Francisco } & \text { SF_LS5 } & 30 & \text { NE } & 714261 & 9560467 & 1954 & \text { lower slope } \\ \text { San Francisco } & \text { SF_LS6 } & 35 & \text { NE } & 714258 & 9560423 & 1933 & \text { lower slope }\end{array}$




\section{Appendix 4: Identified pollen and spores of the Tres Lagunas record and the modern pollen rain}

studies from the Podocarpus National Park region - complete list and photos

Appendix 4.1: Table of identified pollen and spore types

Appendix 4.2: Plates of identified pollen and spore types

Remarks:

Morphological descriptions are given if observations differ from those described by Hooghiemstra (1984), Roubik and Moreno (1991), Bush and Weng (2007) or Brunschön (2010).

Pollen and spore photos were taken by Jan Hoeber, Jenna Kulp and by myself.

Vegetation classification is given as Vegetation type for the pollen grains recorded at the Quimsacocha sediment core and as tree/non tree classification for the ones recorded in the modern pollen traps and surface samples.

The abbreviations of the pollen records are as follows:

TL - Tres Lagunas sediment core (Quimsacocha volcanic basin), CAJ-PAR - Modern pollen rain from the Páramo of Cajanuma, BO-PMF - Modern pollen rain from the premontane forest at Bombuscaro, SF-LMF - Modern pollen rain from the lower montane forest at San Francisco, CAJUMF - Modern pollen rain from the upper montane forest at Cajanuma, PAR - Páramo, SUBPAR Subpáramo, UMF - Upper montane forest, LMF - Lower montane forest. 


\section{References}

Brunschön, C. 2010. Late Quaternary landscape dynamics in the Podocarpus National Park region in the southeastern Andes of Ecuador. PhD thesis, Göttingen University, Göttingen.

Bush, M. B., and C. Weng. 2007. Introducing a new (freeware) tool for palynology. Journal of Biogeography 34:377-380.

Hooghiemstra, H. 1984. Vegetation and Climatic History of the High Plain of Bogota, Colombia. J. Cramer, Vaduz.

Roubik, D. W., and J. E. Moreno. 1991. Pollen and Spores of Barro Colorado Island. Missouri Botanical Garden, St. Louis, Missouri. 


\section{Appendix 4.1.1 List of identified pollen types}

\begin{tabular}{|c|c|c|c|c|c|c|c|c|c|c|}
\hline $\begin{array}{l}\text { Foto } \\
\text { no. }\end{array}$ & Taxon & Family & Tree & $\begin{array}{l}\text { Veg. } \\
\text { type }\end{array}$ & Morphology & TL & $\begin{array}{l}\text { CAJ- } \\
\text { PAR }\end{array}$ & $\begin{array}{l}\text { BO- } \\
\text { PMF }\end{array}$ & $\begin{array}{l}\text { SF- } \\
\text { LMF }\end{array}$ & $\begin{array}{l}\text { CAJ- } \\
\text { UMF }\end{array}$ \\
\hline 132 & Acanthaceae & Acanthaceae & no & & & & & 1 & & \\
\hline 73 & Saurauia & Actinidiaceae & yes & & $\begin{array}{l}\text { Tricolporate, psilate to scabrate, } \\
\text { prolate, ca. } 18-22 \mu \mathrm{m}\end{array}$ & & & 1 & 1 & \\
\hline \multirow[t]{2}{*}{119} & Viburnum & Adoxaceae & yes & & & & & 1 & 1 & 1 \\
\hline & Sagittaria/Echinodorus type & Alismataceae & PAR & & & 1 & & & & \\
\hline 13 & Bomarea type & Alstroemeriaceae & no & SUBPAR & & 1 & 1 & & & 1 \\
\hline 67 & Alzatea type & Alzateaceae & yes & & $\begin{array}{l}\text { Tricolporidate, psilate, prolate } 15-18 \\
\mu \mathrm{m}\end{array}$ & & & 1 & 1 & \\
\hline \multirow[t]{4}{*}{54} & Amaranthaceae/Chenopodiaceae & $\begin{array}{l}\text { Amaranthaceae/ } \\
\text { Chenopodiaceae }\end{array}$ & no & others & & 1 & 1 & 1 & & 1 \\
\hline & Althernanthera type & $\begin{array}{l}\text { Amaranthaceae/ } \\
\text { Chenopodiaceae }\end{array}$ & no & others & & 1 & & & 1 & 1 \\
\hline & Deeringia Morphotype & $\begin{array}{l}\text { Amaranthaceae/ } \\
\text { Chenopodiaceae }\end{array}$ & others & & & 1 & & & & \\
\hline & Schinus type & Anacardiaceae & yes & PAR & & 1 & 1 & 1 & & \\
\hline 123 & Mauria type & Anacardiaceae & yes & & $\begin{array}{l}\text { Scabrate to reticulate (pore section), } \\
\text { subprolate, pores rectangular broad } \\
\text { to concave, ca. } 25 \mu \mathrm{m}\end{array}$ & & & & 1 & \\
\hline \multirow[t]{2}{*}{124} & Tapirira & Anacardiaceae & yes & & & & & 1 & & \\
\hline & Anacardiaceae & Anacardiaceae & yes & & & & 1 & 1 & & 1 \\
\hline 138 & Annonaceae & Annonaceae & yes & & & & & 1 & & \\
\hline 91 & Hydrocotyle & Apiaceae & & PAR & & 1 & & & & \\
\hline 84 & Apiaceae psilate & Apiaceae & no & PAR & & 1 & 1 & & 1 & 1 \\
\hline \multirow[t]{2}{*}{89} & Eryngium type & Apiaceae & & PAR & & 1 & & & & \\
\hline & Apiaceae reticulate & Apiaceae & no & & & & 1 & & & 1 \\
\hline \multirow[t]{2}{*}{133} & Ilex & Aquifoliaceae & yes & UMF & & 1 & & 1 & 1 & 1 \\
\hline & Anthurium & Araceae & no & & & & & & & 1 \\
\hline
\end{tabular}




\begin{tabular}{|c|c|c|c|c|c|c|c|c|c|c|}
\hline 95 & Araliaceae spp. & Araliaceae & yes & & & & & 1 & & \\
\hline 96 & Dendropanax type & Araliaceae & yes & & & & & 1 & 1 & 1 \\
\hline 97 & Oreopanax type & Araliaceae & yes & SUBPAR & & 1 & 1 & 1 & 1 & 1 \\
\hline 98 & Schefflera & Araliaceae & yes & & & & & & 1 & 1 \\
\hline 14 & Arecaceae psilate & Arecaceae & yes & & & & & 1 & 1 & \\
\hline \multirow[t]{3}{*}{15} & Arecaceae pilate & Arecaceae & yes & & & & & 1 & 1 & 1 \\
\hline & Arecaceae echinate & Arecaceae & yes & & & & & 1 & 1 & \\
\hline & Arecaceae reticulate & Arecaceae & yes & & & & & 1 & 1 & \\
\hline 127 & Chuquiraga type & Asteraceae & yes & & $\begin{array}{l}\text { Tricolporate, microechinate, ca. } 30- \\
35 \mu \mathrm{m}\end{array}$ & & 1 & & & 1 \\
\hline 128 & Senecio type & Asteraceae & & PAR & & 1 & & & & \\
\hline 129 & Baccharis type & Asteraceae & & PAR & & 1 & 1 & 1 & 1 & 1 \\
\hline 130 & Vernonia type & Asteraceae & & PAR & & 1 & & & & \\
\hline \multirow[t]{6}{*}{131} & Ambrosia type & Asteraceae & yes & PAR & & 1 & 1 & 1 & 1 & 1 \\
\hline & Asteraceae undiff. & Asteraceae & yes & PAR & & 1 & & & & \\
\hline & Cichorioidae & Asteraceae & yes & PAR & & 1 & 1 & 1 & 1 & 1 \\
\hline & Perezia type & Asteraceae & yes & & & & & 1 & & \\
\hline & Piptocoma type & Asteraceae & yes & & & & & & 1 & \\
\hline & Asteraceae Type 1 & Asteraceae & & PAR & & 1 & & & & \\
\hline 74 & Begonia type & Begoniaceae & PAR & & & 1 & & & & \\
\hline 51 & Berberidaceae & Berberidaceae & no & & & & & & & 1 \\
\hline 50 & Alnus & Betulaceae & yes & UMF & & 1 & 1 & 1 & 1 & 1 \\
\hline 10 & Bignoniaceae & Bignoniaceae & yes & & & & & 1 & & \\
\hline 107 & Tabebuia & Bignoniaceae & yes & & & & & & 1 & \\
\hline 6 & Tournefortia & Boraginaceae & yes & & & & & & 1 & \\
\hline \multirow[t]{3}{*}{75} & Cordia & Boraginaceae & yes & & & & & 1 & & \\
\hline & Boraginaceae & Boraginaceae & yes & & & 1 & & & & \\
\hline & Brassicaceae & Brassicaceae & no & PAR & & 1 & & & & \\
\hline
\end{tabular}




\begin{tabular}{|c|c|c|c|c|c|c|c|c|c|}
\hline 17 & Puya type & Bromeliaceae & no & & & & & 1 & 1 \\
\hline & Bromeliaceae & Bromeliaceae & no & & & & 1 & 1 & 1 \\
\hline 76 & Burseraceae & Burseraceae & yes & & & & 1 & & \\
\hline 64 & Lysipomia & Campanulaceae & no & PAR & 1 & & & & \\
\hline \multirow[t]{2}{*}{78} & Campanulaceae & Campanulaceae & no & & & 1 & 1 & 1 & 1 \\
\hline & Trema & Cannabaceae & yes & & & & & & 1 \\
\hline 55 & Caryophyllaceae & Caryophyllaceae & no & PAR & 1 & 1 & & & 1 \\
\hline 35 & Cecropia & Cecropiaceae & yes & LMF & 1 & & & & \\
\hline \multirow[t]{2}{*}{102} & Maytenus & Celastraceae & yes & & & 1 & 1 & 1 & 1 \\
\hline & Celastraceae & Celastraceae & yes & & & & 1 & 1 & 1 \\
\hline 3 & Hedyosmum & Chloranthaceae & yes & UMF & 1 & 1 & 1 & 1 & 1 \\
\hline \multirow[t]{2}{*}{1} & Licania type & Chrysobalanaceae & yes & & & & 1 & & \\
\hline & Chrysobalanaceae scabrate & Chrysobalanaceae & yes & & & & 1 & & \\
\hline 68 & Clethra type & Clethraceae & yes & SUBPAR & 1 & 1 & & 1 & 1 \\
\hline 108 & Vismia/Chrysochlamis type & Clusiaceae & yes & & & & 1 & 1 & \\
\hline 109 & Clusia type & Clusiaceae & yes & & & 1 & 1 & 1 & 1 \\
\hline \multirow[t]{3}{*}{110} & Hypericum & Clusiaceae & no & SUBPAR & 1 & 1 & & & \\
\hline & Clusiaceae & Clusiaceae & yes & & & 1 & 1 & & 1 \\
\hline & Convolvulaceae baculate & Convolvulaceae & no & PAR & 1 & & 1 & 1 & \\
\hline 117 & Weinmannia & Cunoniaceae & yes & UMF & 1 & 1 & 1 & 1 & 1 \\
\hline 56 & Cyperaceae & Cyperaceae & no & PAR & 1 & 1 & 1 & 1 & 1 \\
\hline 71 & Elaeocarpaceae & Elaeocarpaceae & yes & UMF & 1 & 1 & & & \\
\hline 137 & Ericaceae & Ericaceae & yes & PAR & 1 & 1 & & & \\
\hline 32 & Eriocaulon type & Eriocaulaceae & PAR & & 1 & & & & \\
\hline 79 & Escallonia type & Escalloniaceae & yes & & & 1 & & & \\
\hline 2 & Croton & Euphorbiaceae & yes & & & 1 & & 1 & \\
\hline 66 & Acalypha & Euphorbiaceae & yes & LMF & 1 & 1 & 1 & 1 & 1 \\
\hline 87 & Alchornea type & Euphorbiaceae & yes & LMF & 1 & 1 & 1 & 1 & 1 \\
\hline
\end{tabular}




\begin{tabular}{|c|c|c|c|c|c|c|c|c|c|c|}
\hline 103 & Mabea & Euphorbiaceae & yes & & & & & 1 & & \\
\hline & Euphorbiaceae & Euphorbiaceae & yes & others & & 1 & & 1 & 1 & 1 \\
\hline & Sebastiana type & Euphorbiaceae & yes & & & & 1 & 1 & 1 & \\
\hline & Sapium & Euphorbiaceae & yes & & & & & 1 & 1 & \\
\hline 142 & Mimosaceae (polyad) & Fabaceae & yes & & & & & 1 & 1 & 1 \\
\hline \multirow[t]{2}{*}{143} & Anadenanthera Morphotype & Fabaceae & yes & & & & 1 & & 1 & 1 \\
\hline & Mimosaceae (tetrad) & Fabaceae & yes & others & & 1 & 1 & 1 & 1 & 1 \\
\hline 80 & Fabaceae psilate & Fabaceae & yes & PAR & & 1 & 1 & & 1 & 1 \\
\hline 111 & Fabaceae reticulate & Fabaceae & yes & & & & 1 & & & \\
\hline 45 & Erythrina & Fabaceae & yes & & & & & & & 1 \\
\hline 116 & Banara & Flacourtiaceae & yes & & & & & 1 & & \\
\hline 101 & Casearia & Flacourtiaceae & yes & & & & & 1 & & \\
\hline 104 & Gentianella type & Gentianaceae & & PAR & & 1 & & & & \\
\hline \multirow[t]{2}{*}{105} & Macrocarpea & Gentianaceae & yes & LMF & & 1 & & 1 & 1 & 1 \\
\hline & Gentianaceae & Gentianaceae & no & PAR & & 1 & 1 & & & \\
\hline 18 & Geranium & Geraniaceae & no & PAR & & 1 & 1 & & & \\
\hline 53 & Ribes & Grossulariaceae & no & & $\begin{array}{l}\text { Stephanoporate, psilate, circular, ca. } \\
25-30 \mu \mathrm{m}\end{array}$ & & & & & 1 \\
\hline 21 & Gunnera & Gunneraceae & no & SUBPAR & & 1 & & & & 1 \\
\hline 118 & Hydrangaeaceae & Hydrangaeaceae & no & & & & & & & 1 \\
\hline 141 & Tetrade psi & Indeterminate & no & Unknown & $\begin{array}{l}\text { Tetrade, single grains tricolporate, } \\
\text { psilate, ca. } 20 \mu \mathrm{m}\end{array}$ & 1 & 1 & 1 & & \\
\hline 12 & Iridaceae & Iridaceae & no & PAR & & 1 & & & & \\
\hline \multirow[t]{2}{*}{52} & "Juglans" Morphotype & Juglandaceae & yes & others & & 1 & & & 1 & 1 \\
\hline & Lacistemataceae & Lacistemataceae & yes & & & & & 1 & & \\
\hline 31 & Lamiaceae & Lamiaceae & no & PAR & & 1 & & & & 1 \\
\hline 4 & Lauraceae & Lauraceae & yes & & & & 1 & 1 & 1 & 1 \\
\hline \multirow[t]{2}{*}{112} & Lecytidaceae & Lecythidaceae & yes & & & & & 1 & 1 & \\
\hline & Liliaceae & Liliaceae & no & PAR & & 1 & & & & \\
\hline
\end{tabular}




\begin{tabular}{|c|c|c|c|c|c|c|c|c|c|}
\hline 27 & Tristerix longebracteatus type & Loranthaceae & yes & & & & 1 & 1 & 1 \\
\hline 28 & Loranthaceae & Loranthaceae & yes & & & 1 & & & \\
\hline 23 & Gaiadendron type & Loranthaceae & & SUBPAR & 1 & & & & \\
\hline 60 & Malpighiaceae & Malpighiaceae & yes & & & & 1 & 1 & \\
\hline 77 & Byrsonima & Malpighiaceae & yes & & & & & 1 & 1 \\
\hline 62 & Malvaceae & Malvaceae & yes & & & & 1 & & \\
\hline 106 & Heliocarpus americanus & Malvaceae & yes & & & & 1 & 1 & 1 \\
\hline 115 & Apeiba & Malvaceae & yes & & & & 1 & & \\
\hline 134 & Melastomataceae & Melastomataceae & yes & SUBPAR & 1 & 1 & 1 & 1 & 1 \\
\hline 65 & Meliaceae & Meliaceae & yes & & & & 1 & 1 & 1 \\
\hline 5 & Menispermaceae & Menispermaceae & yes & & & & 1 & 1 & \\
\hline 36 & Moraceae/Urticaceae & $\begin{array}{l}\text { Moraceae/ } \\
\text { Urticaceae }\end{array}$ & yes & LMF & 1 & 1 & 1 & 1 & 1 \\
\hline 39 & Myrica & Myricaceae & yes & UMF & 1 & 1 & 1 & 1 & 1 \\
\hline 16 & Myristicaceae & Myristicaceae & yes & & & & 1 & & \\
\hline \multirow[t]{2}{*}{30} & Myrteola type & Myrtaceae & & SUBPAR & 1 & & & & \\
\hline & Myrtaceae & Myrtaceae & yes & UMF & 1 & 1 & 1 & 1 & 1 \\
\hline \multirow[t]{2}{*}{25} & Nyctaginaceae & Nyctaginaceae & yes & & & & 1 & 1 & \\
\hline & Ouratea type & Ochnaceae & & LMF & 1 & & & & \\
\hline 24 & Heisteria type & Olacaceae & yes & & & & 1 & & \\
\hline 140 & Orchidaceae & Orchidaceae & no & others & 1 & 1 & 1 & & \\
\hline 61 & Bocconia integrifolia & Papaveraceae & yes & UMF & 1 & 1 & & 1 & 1 \\
\hline \multirow[t]{2}{*}{81} & Hieronyma & Phyllanthaceae & yes & & & & 1 & 1 & 1 \\
\hline & Richeria type & Phyllanthaceae & yes & & & & 1 & & \\
\hline 136 & Pinus & Pinaceae & yes & others & 1 & 1 & & 1 & 1 \\
\hline 11 & Piperaceae & Piperaceae & yes & LMF & 1 & 1 & 1 & 1 & 1 \\
\hline 57 & Plantago rigida type & Plantaginaceae & no & & 1 & & & & \\
\hline 58 & Plantago lanceolata & Plantaginaceae & no & & 1 & & & & 1 \\
\hline
\end{tabular}




\begin{tabular}{|c|c|c|c|c|c|c|c|c|c|}
\hline & Plantago australis type & Plantaginaceae & & PAR & 1 & & & & \\
\hline & Plantago rigida type & Plantaginaceae & & PAR & 1 & & & & \\
\hline & Plantago spp. & Plantaginaceae & & & 1 & & & & \\
\hline & Plantago australis type & Plantaginaceae & & & 1 & & & & \\
\hline \multirow[t]{2}{*}{34} & Poaceae & Poaceae & no & PAR & 1 & 1 & 1 & 1 & 1 \\
\hline & Zea mays & Poaceae & & others & 1 & & & & \\
\hline \multirow[t]{2}{*}{135} & Podocarpaceae & Podocarpaceae & yes & UMF & 1 & 1 & 1 & 1 & 1 \\
\hline & Polygala & Polygalaceae & no & PAR & 1 & & & 1 & \\
\hline \multirow[t]{2}{*}{33} & Monnina type & Polygalaceae & no & & & 1 & & 1 & \\
\hline & Polygonum & Polygonaceae & PAR & & 1 & & & & \\
\hline 92 & Triplaris & Polygonaceae & yes & & & & 1 & 1 & \\
\hline \multirow[t]{2}{*}{126} & Rumex/Muehlenbeckia type & Polygonaceae & no & SUBPAR & 1 & 1 & & & 1 \\
\hline & Geissanthus & Primulaceae & yes & & & & 1 & & 1 \\
\hline 26 & Myrsine & Primulaceae & yes & UMF & 1 & 1 & 1 & 1 & 1 \\
\hline 69 & Cybianthus type & Primulaceae & yes & & & & & 1 & 1 \\
\hline 46 & Lomatia hirsuta type & Proteaceae & & PAR & 1 & & & & \\
\hline 47 & Roupala & Proteaceae & yes & & & & & 1 & \\
\hline 49 & Proteaceae & Proteaceae & yes & & & & 1 & & 1 \\
\hline \multirow[t]{2}{*}{20} & Ranunculus & Ranunculaceae & no & PAR & 1 & 1 & & & \\
\hline & Thalictrum & Ranunculaceae & PAR & & 1 & & & & \\
\hline 82 & Rhamnaceae & Rhamnaceae & no & & & 1 & & & \\
\hline 120 & Prunus type & Rosaceae & yes & & & & 1 & 1 & \\
\hline 121 & Rosaceae spp. & Rosaceae & yes & & & 1 & & & \\
\hline 122 & Hesperomeles & Rosaceae & yes & & & 1 & & & 1 \\
\hline 40 & Polylepis/Acaena & Rosaceae & no & UMF & 1 & & & & 1 \\
\hline 8 & Psychotria type & Rubiaceae & & LMF & 1 & & 1 & 1 & 1 \\
\hline 9 & Rubiaceae Inaperturate & Rubiaceae & yes & & & & 1 & 1 & 1 \\
\hline 59 & Borreria type & Rubiaceae & yes & & & & 1 & & \\
\hline
\end{tabular}




\begin{tabular}{|c|c|c|c|c|c|c|c|c|c|}
\hline 63 & Rubiaceae C6P6 & Rubiaceae & yes & & & 1 & 1 & & \\
\hline & Spermacoce & Rubiaceae & no & & & & & & 1 \\
\hline 93 & Cinchona type & Rubiaceae & yes & & & & & & 1 \\
\hline 99 & Arcytophyllum type & Rubiaceae & no & PAR & 1 & 1 & & 1 & 1 \\
\hline \multirow[t]{4}{*}{100} & Diocodendron & Rubiaceae & & PAR & 1 & & & & \\
\hline & Rubiaceae & Rubiaceae & yes & & & & 1 & 1 & 1 \\
\hline & Rubiaceae pilat & Rubiaceae & yes & & & & & & 1 \\
\hline & Rubiaceae small & Rubiaceae & yes & & & 1 & 1 & 1 & 1 \\
\hline 41 & Faramea type & Rubiaceae & yes & & & & & 1 & 1 \\
\hline 43 & Guettarda & Rubiaceae & yes & & & & 1 & 1 & \\
\hline 114 & Zanthoxylum & Rutaceae & yes & & & 1 & & 1 & \\
\hline 113 & Meliosma & Sabiaceae & yes & & & & 1 & 1 & 1 \\
\hline 29 & Cupania & Sapindaceae & yes & & & & 1 & & \\
\hline \multirow[t]{2}{*}{94} & Dodonaea type & Sapindaceae & yes & UMF & 1 & 1 & 1 & 1 & 1 \\
\hline & Dodonaea striate & Sapindaceae & yes & & & 1 & 1 & 1 & 1 \\
\hline 44 & Sapindaceae & Sapindaceae & yes & & & & 1 & 1 & 1 \\
\hline 48 & Allophylus & Sapindaceae & yes & & & & & 1 & \\
\hline \multirow[t]{2}{*}{86} & Pouteria & Sapotaceae & yes & & & & 1 & & \\
\hline & Sapotaceae & Sapotaceae & yes & & & & 1 & 1 & \\
\hline 69 & Buddleja & Scrophulariaceae & no & & & & & & \\
\hline 70 & Scrophulariaceae & Scrophulariaceae & & PAR & 1 & & & & \\
\hline 7 & Siparuna & Siparunaceae & yes & & & & 1 & 1 & \\
\hline 72 & Solanum type & Solanaceae & yes & others & 1 & 1 & 1 & 1 & 1 \\
\hline \multirow[t]{3}{*}{125} & Cestrum & Solanaceae & yes & & & & 1 & 1 & \\
\hline & Solanaceae & Solanaceae & yes & & & & 1 & 1 & \\
\hline & Byttneria & Staphyleaceae & yes & others & 1 & & & & \\
\hline \multirow[t]{2}{*}{90} & Sterculiaceae & Sterculiaceae & yes & & & & 1 & 1 & \\
\hline & Turpinia & Sterculiaceae & yes & & & & & 1 & \\
\hline
\end{tabular}




\begin{tabular}{|c|c|c|c|c|c|c|c|c|c|c|}
\hline 38 & Symplocos & Symplocaceae & yes & & & & & & 1 & 1 \\
\hline 83 & Ternstroemia & Theaceae & yes & & & & & & & 1 \\
\hline 42 & Gordonia & Theaceae & yes & & & & 1 & & & \\
\hline \multirow[t]{11}{*}{37} & Celtis & Ulmaceae & yes & LMF & & 1 & 1 & 1 & & 1 \\
\hline & $\begin{array}{l}\text { Type micoreticulate, } 10 \mu \mathrm{m} \text {, exine } \\
\text { thick }\end{array}$ & Unknown & & Unknown & $\begin{array}{l}\text { Tricolporate, microreticulate. Exine } \\
\text { ca. } 2 \mu \mathrm{m} \text {, subprolate, ca, } 10 \mu \mathrm{m},\end{array}$ & 1 & & & & \\
\hline & С3Р3 psilate, different types & Unknown & & Unknown & Tricolporate psilate, different types & 1 & & & & \\
\hline & С 3 P3 reticulate, different types & Unknown & & Unknown & $\begin{array}{l}\text { Tricolporate reticulate, different } \\
\text { types }\end{array}$ & 1 & & & & \\
\hline & cf. Rubiaceae & Unknown & & Unknown & $\begin{array}{l}\text { Tricolporate, reticulate, ca. } 25 \mu \mathrm{m} \text {, } \\
\text { prolate }\end{array}$ & 1 & & & & \\
\hline & cf. Combretaceae & Unknown & & Unknown & $\begin{array}{l}\text { Heterocolporidate, psilate, } \\
\text { subprolate, ca. } 25 \mu \mathrm{m}\end{array}$ & 1 & & & & \\
\hline & cf. Euphorbiaceae & Unknown & & Unknown & Tricolporate, baculate, ca. $25 \mu \mathrm{m}$ & 1 & & & & \\
\hline & cf. Juncaginaceae & Unknown & & Unknown & $\begin{array}{l}\text { Inaperturate, reticulate, very thin } \\
\text { exine, ca. } 25 \mu \mathrm{m}\end{array}$ & 1 & & & & \\
\hline & cf. Menispermaceae & Unknown & & Unknown & Inaperturate, baculate, ca. $10 \mu \mathrm{m}$ & 1 & & & & \\
\hline & cf. Pera & Unknown & & Unknown & $\begin{array}{l}\text { Tricolporate, subprolate, scabrate to } \\
\text { reticulate ca. } 25 \mu \mathrm{m} \text {, }\end{array}$ & 1 & & & & \\
\hline & cf. Quercus & Unknown & & Unknown & $\begin{array}{l}\text { Tricolporate to tricolpate, scabrate, } \\
\text { ca. } 30 \mu \mathrm{m}\end{array}$ & 1 & & & & \\
\hline 19 & Valeriana & Valerianaceae & no & PAR & & 1 & 1 & & & \\
\hline 22 & Aegiphila & Verbenaceae & yes & & & & & 1 & & \\
\hline \multirow[t]{2}{*}{88} & Verbenaceae & Verbenaceae & yes & & & & 1 & & & \\
\hline & Leonia & Violaceae & yes & & & & & 1 & & \\
\hline 85 & Vitaceae & Vitaceae & no & & & & 1 & & 1 & 1 \\
\hline \multirow[t]{2}{*}{139} & Drymis granadensis & Winteraceae & yes & & & & 1 & & & 1 \\
\hline & Xyris & Xyridaceae & no & & & & 1 & & & \\
\hline
\end{tabular}


Appendix 4.1.2 List of identified spore types

\begin{tabular}{|c|c|c|c|c|c|c|c|c|c|}
\hline Foto no. & Sample & Element & Tree & Morphology & TL & CAJ-PAR & BO- PMF & SF- LMF & CAJ- UMF \\
\hline & Anthoceros type & Anthocerotaceae & no & & & & & & 1 \\
\hline & Blechnum type & Blechnaceae & & Fern & 1 & & & & \\
\hline & Bryophyta & Bryophyta & no & & & & 1 & & \\
\hline 146 & Cyathea horrida type & Cyatheaceae & yes & & & 1 & 1 & 1 & \\
\hline \multirow[t]{4}{*}{147} & Cyathea psilate & Cyatheaceae & yes & Fern & 1 & 1 & 1 & 1 & 1 \\
\hline & Cyathea cf. conjugata type & Cyatheaceae & & Fern & 1 & & & & \\
\hline & Cyathea type reticulate & Cyatheaceae & & Fern & 1 & & & & \\
\hline & Cyathea verrucate & Cyatheaceae & yes & Fern & & 1 & 1 & 1 & 1 \\
\hline \multirow[t]{4}{*}{148} & Lophosoria quadripinnata & Dicksoniaceae & no & Fern & 1 & & 1 & & \\
\hline & Dicksonia sellowiana & Dicksoniaceae & & Fern & 1 & & & & \\
\hline & cf. Elaphoglossum & Dryopteridaceae & no & Fern & & & 1 & 1 & 1 \\
\hline & Grammitis & Grammitidaceae & & Fern & 1 & & & & \\
\hline \multirow[t]{3}{*}{150} & Hymenophyllum type & Hymenophyllaceae & & Fern & 1 & & & & \\
\hline & Pteridophyta (Trilete, scabrate) & Indeterminate & no & & & 1 & 1 & 1 & 1 \\
\hline & Isoëtes & Isoetaceae & no & & 1 & 1 & & & \\
\hline 144 & Huperzia & Lycopodiaceae & no & Fern & 1 & 1 & & & \\
\hline \multirow[t]{9}{*}{145} & Lycopodium cernuum type & Lycopodiaceae & no & & & 1 & 1 & 1 & 1 \\
\hline & Lycopodium alupecuroides type & Lycopodiaceae & & Fern & 1 & & & & \\
\hline & Lycopodium clavatum type & Lycopodiaceae & no & & & 1 & 1 & & 1 \\
\hline & Lycopodium curvatum type & Lycopodiaceae & & Fern & 1 & & & & \\
\hline & Lycopodium foveolat & Lycopodiaceae & no & & & 1 & & & \\
\hline & Lycopodium type 1 & Lycopodiaceae & & Fern & 1 & & & & \\
\hline & Ophioglossum & Ophioglossaceae & & Fern & 1 & & & & \\
\hline & Osmunda & Osmundaceae & no & Fern & & 1 & 1 & 1 & 1 \\
\hline & Lellingeria type & Polypodiaceae & & Fern & 1 & & & & \\
\hline
\end{tabular}




\begin{tabular}{|c|c|c|c|c|c|c|c|c|c|c|}
\hline 149 & Jamesonia type & Pteridaceae & no & & & & 1 & 1 & & 1 \\
\hline & Pityrogramma & Pteridaceae & no & & & & & 1 & & \\
\hline & Pteris type & Pteridaceae & & Fern & & 1 & & & & \\
\hline \multirow[t]{17}{*}{151} & Selaginella & Selaginellaceae & no & Fern & & 1 & & 1 & 1 & \\
\hline & Sphagnum & Sphagnaceae & no & & & & 1 & & & \\
\hline & cf. Paesia viscosa type & Unknown & & Fern & & 1 & & & & \\
\hline & Trilete type verrucate & Unknown & no & Fern & Trilete verrucate, ca. $40 \mu \mathrm{m}$ & 1 & 1 & 1 & 1 & 1 \\
\hline & Trilete Type ver exospore & Unknown & & Fern & $\begin{array}{l}\text { Trilete, verrucate exospore, ca. } 30 \\
\mu \mathrm{m}\end{array}$ & 1 & & & & \\
\hline & Trilete psilate $<50$ & Unknown & no & Fern & $\begin{array}{l}\text { Trilete, psilate, }<50 \mu \mathrm{m} \text {, different } \\
\text { types }\end{array}$ & 1 & 1 & 1 & 1 & 1 \\
\hline & Trilete psilate $>50$ & Unknown & no & Fern & $\begin{array}{l}\text { Trilete, psilate, }>50 \mu \mathrm{m} \text {, different } \\
\text { types }\end{array}$ & 1 & 1 & 1 & 1 & 1 \\
\hline & ML cf. Thelypteridaceae type & Unknown & & Fern & Monolete, rugulate, ca. 40 m & 1 & & & & \\
\hline & ML Type microechinate & Unknown & no & Fern & $\begin{array}{l}\text { Monolete, microechinate, ca. } 30 \\
\mu \mathrm{m}\end{array}$ & 1 & 1 & 1 & 1 & 1 \\
\hline & ML Type ret 20 & Unknown & & Fern & Monolete, reticulate, ca. $20 \mu \mathrm{m}$ & 1 & & & & \\
\hline & ML Type rug exo & Unknown & no & Fern & $\begin{array}{l}\text { Monolete, exospore regulate, ca. } \\
40 \mu \mathrm{m}\end{array}$ & 1 & 1 & 1 & 1 & 1 \\
\hline & ML Type rugulate foveolate & Unknown & & Fern & $\begin{array}{l}\text { Monolete, rugulate to foveolate, } \\
\text { ca. } 40 \mu \mathrm{m}\end{array}$ & 1 & & & & \\
\hline & ML Type verr big ex thin & Unknown & & Fern & $\begin{array}{l}\text { Monolete, verrucate, ca. } 60 \mu \mathrm{m}, \\
\text { thin exospore }\end{array}$ & 1 & & & & \\
\hline & Monolete psilate $<50 \mu \mathrm{m}$ & Unknown & no & Fern & $\begin{array}{l}\text { Monolete psilate, }<50 \mu \mathrm{m}, \\
\text { different types }\end{array}$ & 1 & 1 & 1 & 1 & 1 \\
\hline & Monolete psilate $>50 \mu \mathrm{m}$ & Unknown & no & Fern & $\begin{array}{l}\text { Monolete psilate, }>50 \mu \mathrm{m}, \\
\text { different types }\end{array}$ & 1 & 1 & 1 & 1 & 1 \\
\hline & Monolete verrucate $<50 \mu \mathrm{m}$ & Unknown & no & Fern & $\begin{array}{l}\text { Monolete psilate, }<50 \mu \mathrm{m}, \\
\text { different types }\end{array}$ & 1 & & 1 & 1 & 1 \\
\hline & Monolete verrucate $>50 \mu \mathrm{m}$ & Unknown & no & Fern & $\begin{array}{l}\text { Monolete verrucate, }>50 \mu \mathrm{m}, \\
\text { different types }\end{array}$ & 1 & & 1 & 1 & 1 \\
\hline
\end{tabular}




\section{Inaperturate}

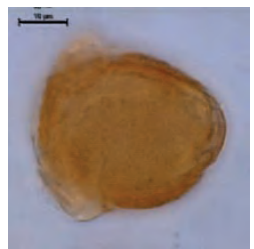

1 Licania type -

Chrysobalanaceae
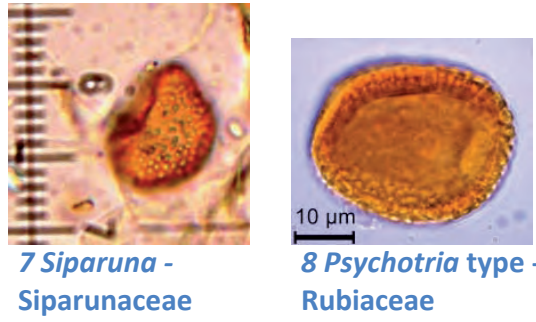

8 Psychotria type Rubiaceae

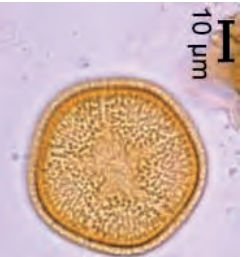

3 Hedyosmum Chloranthaceae

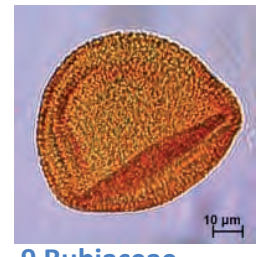

9 Rubiaceae inaperturate

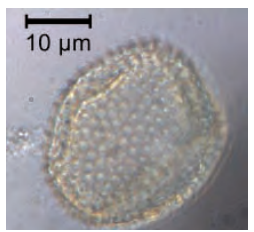

4 Lauraceae

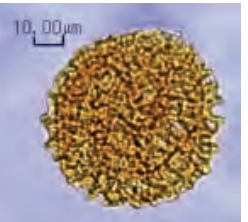

10 Bignoniaceae

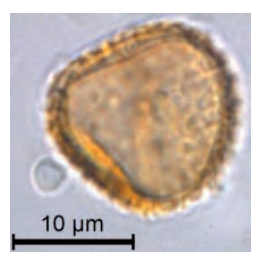

5 Menispermaceae

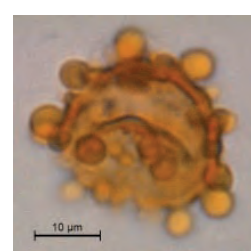

6 Tournefortia Boraginaceae

\section{Monosulcate}

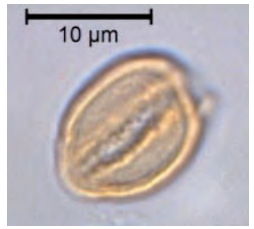

11 Piperaceae

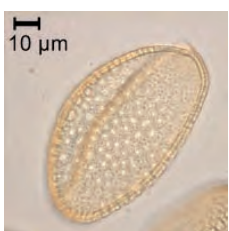

17 Puya -

Bromeliaceae

\section{Tricolpate}

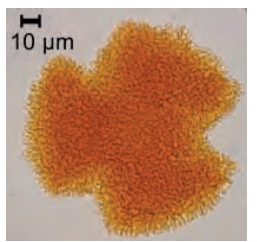

18 Geranium -

Geraniaceae

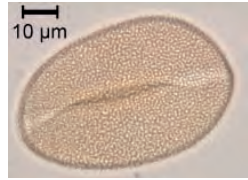

12 Iridaceae

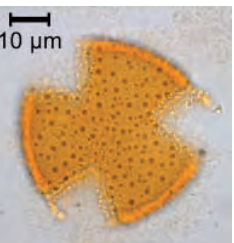

19 Valeriana -

Valerianaceae

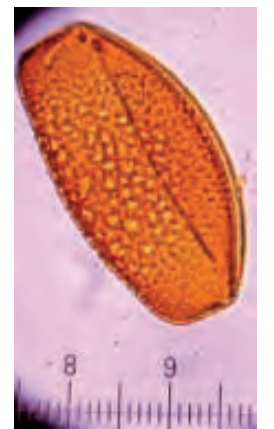

13 Bomarea Alstroemeriaceae

14 Arecaceae psilate

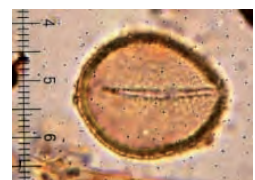

15 Arecaceae pilate

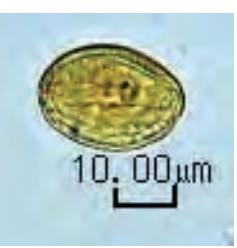

16 Myristicaceae

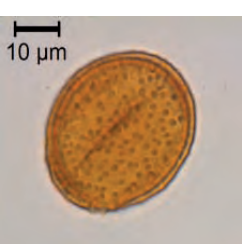

20 Ranunculus Ranunculaceae

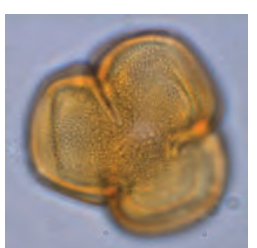

21 Gunnera Gunneraceae

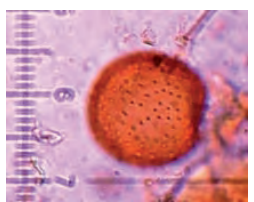

22 Aegiphila Verbenaceae 


\section{Tetracolpate}

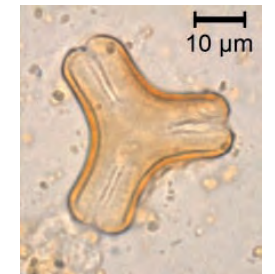

23 Gaiadendron Loranthaceae

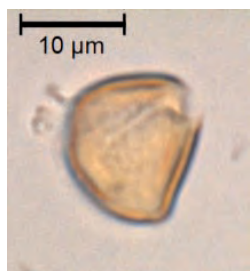

24 Heisteria -

Olacaceae

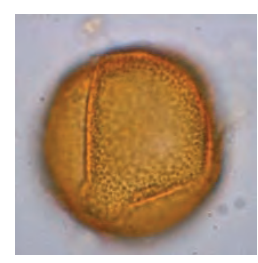

25 Nyctaginaceae

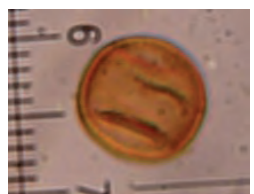

26 Myrsine -

Primulaceae

\section{Syncolpate}

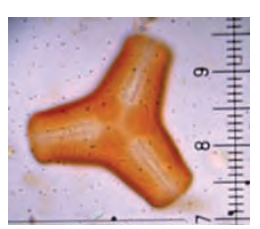

27 Tristerix longebracteatus Loranthaceae

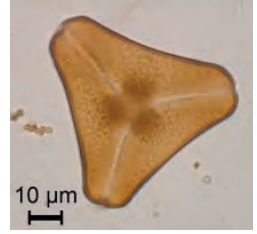

28 Loranthaceae

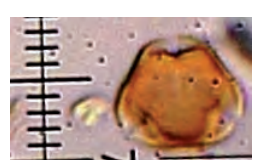

29 Cupania Sapindaceae

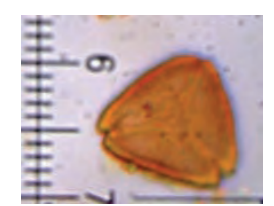

30 Myrteola -

Myrtaceae
Stephanocolpate

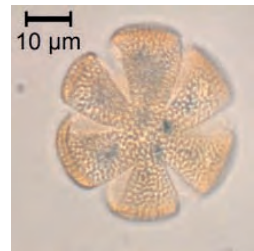

31 Lamiaceae

\section{Spiraperturate Hexacolporate Monoporate}

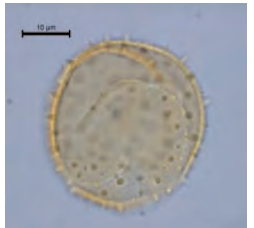

32 Eriocaulaceae

\section{Diporate}

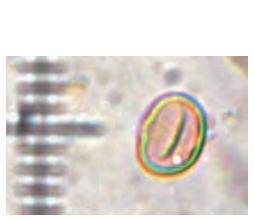

35 Cecropia Urticaceae

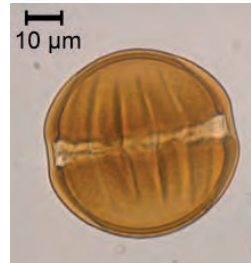

33 Monnina -

Polygalaceae

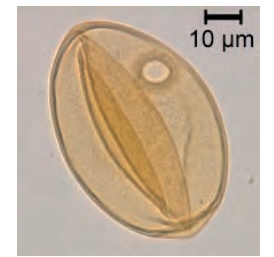

34 Poaceae

\section{Triporate}

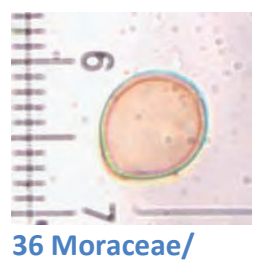

Urticaceae

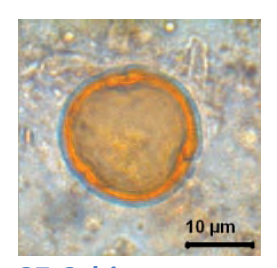

37 Celtis -

Ulmaceae

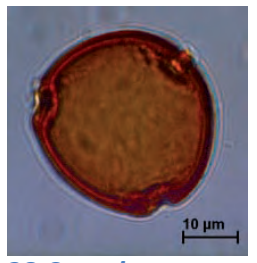

38 Symplocos Symplocaceae

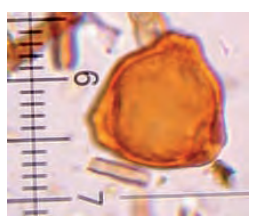

39 Myrica -

Myricaceae

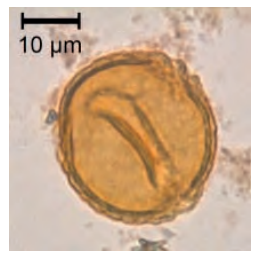

40 Polylepis/Acaena - Rosaceae

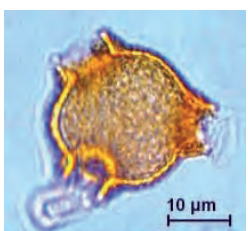

41 Faramea type Rubiaceae

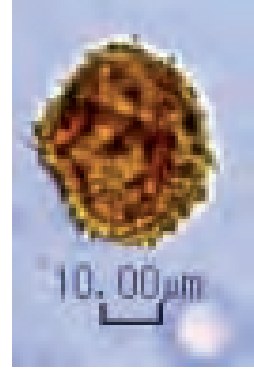

42 Gordonia Theaceae

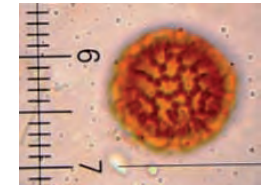

43 Guettarda Rubiaceae

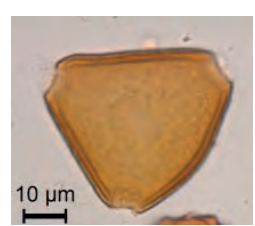

44 Sapindaceae

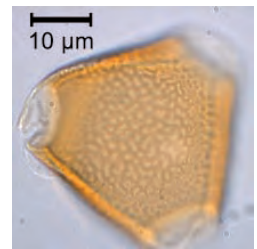

45 Erythrina Fabaceae 


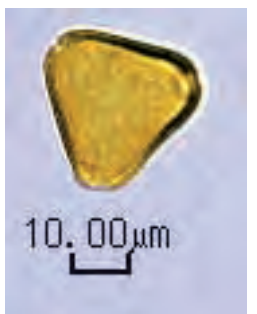

46 Lomatia hirsuta type - Proteaceae

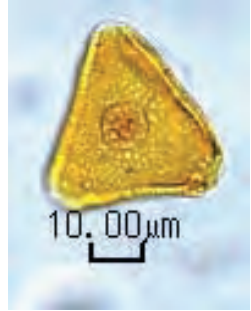

47 Roupala Proteaceae

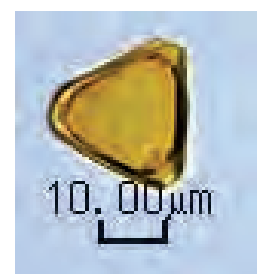

48 Allophylus Sapindaceae

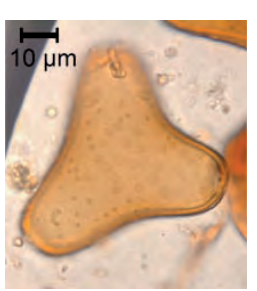

49 Proteaceae

\section{Stephanoporate}

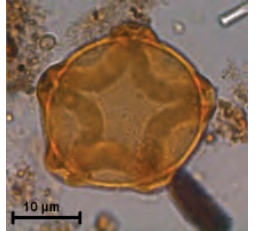

50 Alnus -

Betulaceae

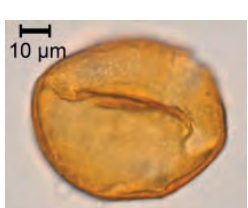

51 Berberidaceae

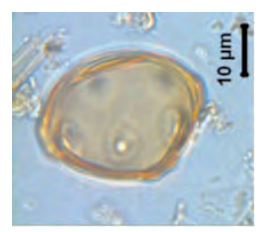

52 ,Juglans" morphotype

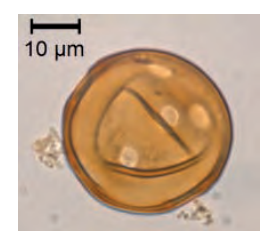

53 Ribes -

Grossulariaceae

\section{Periporate}

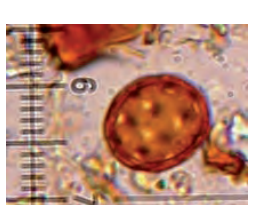

54 Amaranthaceae/ 55 Caryophyllaceae Chenopodiaceae
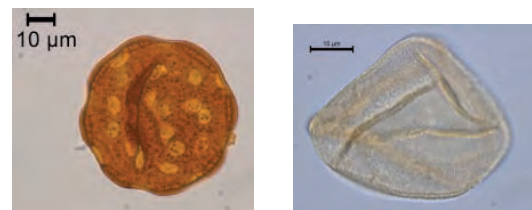

56 Cyperaceae

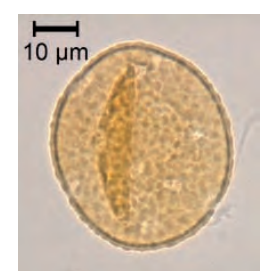

57 Plantago rigida type -

Plantaginaceae

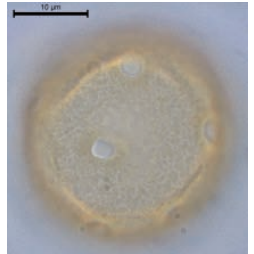

58 Plantago

lanceolata -

Plantaginaceae

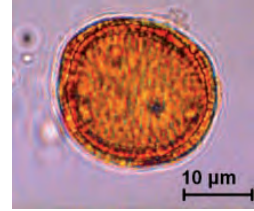

59 Borreria type Rubiaceae

\section{Stephanocolporate}

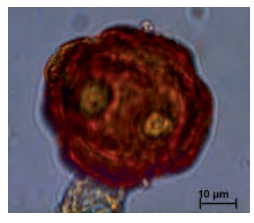

60 Malpighiaceae

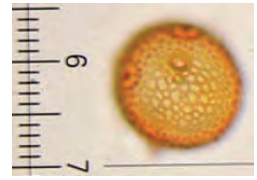

61 Bocconia Papaveraceae

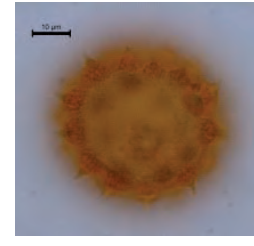

62 Malvaceae

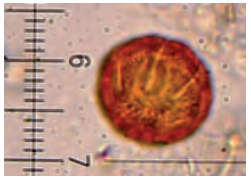

63 Rubiaceae stephanocolporate

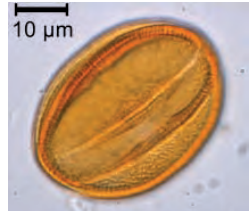

64 Lysipomia -

Campanulaceae

\section{Tetracolporate}

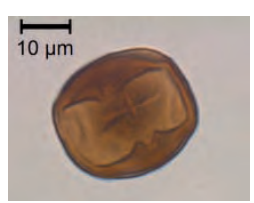

65 Meliaceae

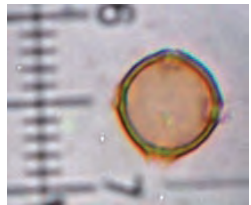

66 Acalypha -

Euphorbiaceae 


\section{Tricolporate}

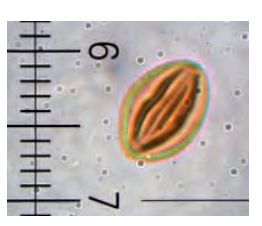

67 Alzateaceae

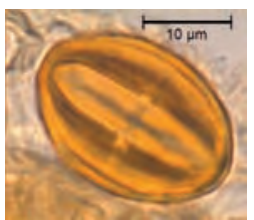

73 Saurauia Actinidiaceae

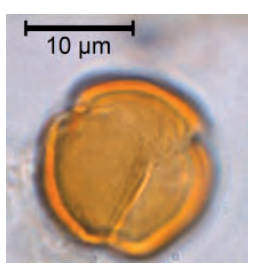

79 Escallonia Escalloniaceae

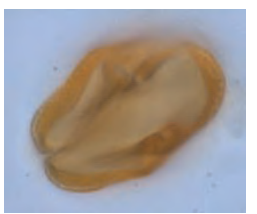

85 Vitaceae

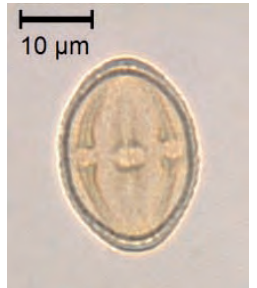

91 Hydrocotyle Apiaceae

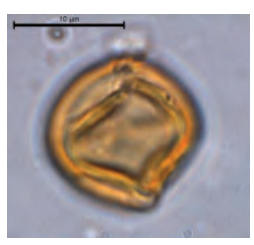

68 Clethra type Clethraceae

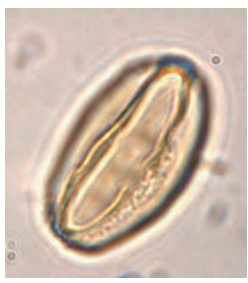

74 Begonia Begoniaceae

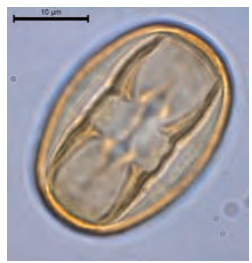

80 Fabaceae psilate

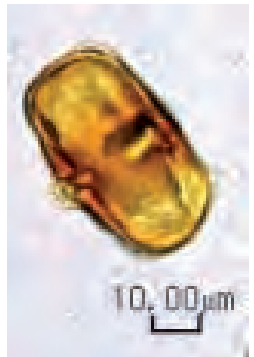

86 Pouteria -

Sapotaceae

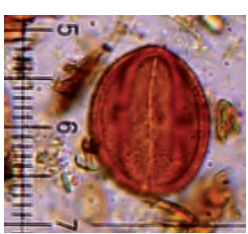

92 Triplaris -

Polygonaceae

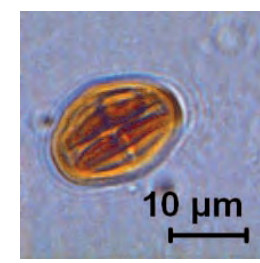

69 Cybianthus Primulaceae

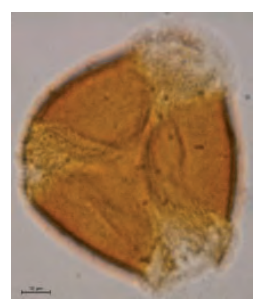

75 Cordia Boraginaceae

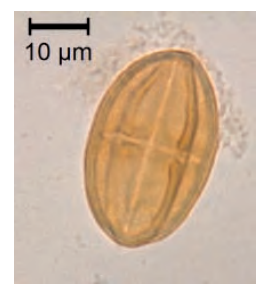

81 Hieronyma -

Phyllanthaceae

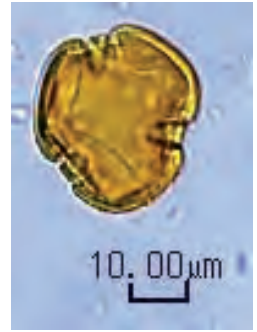

87 Alchornea type - Euphorbiaceae

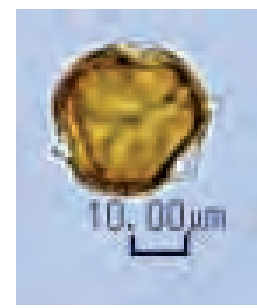

93 Cinchona type

- Rubiaceae

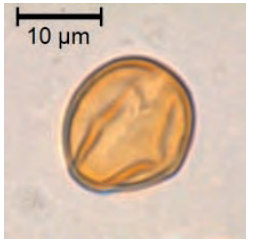

70 Scrophulariaceae 71 Elaeocarpaceae

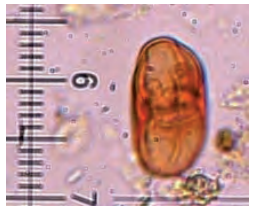

76 Burseraceae

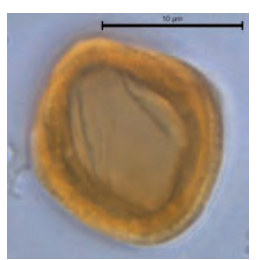

82 Rhamnaceae

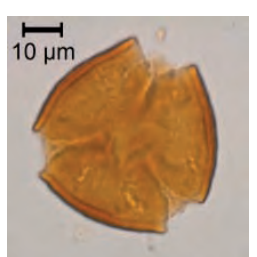

88 Verbenaceae

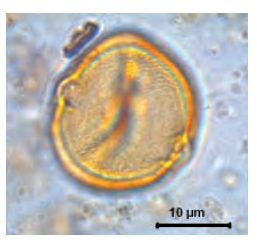

94 Dodonaea type - Sapindaceae
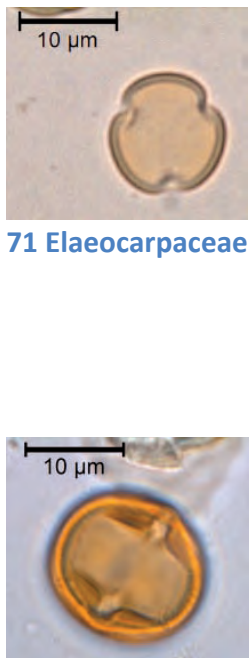

77 Byrsonima Malpighiaceae

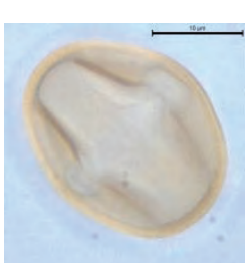

83 Ternstroemia Theaceae

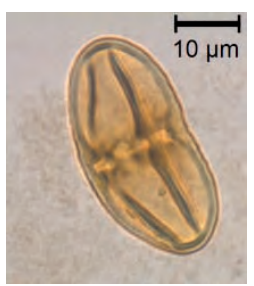

89 Eryngium type - Apiaceae

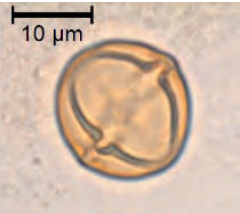

72 Solanum type Solanaceae

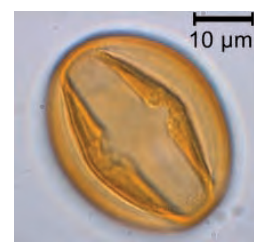

78 Campanulaceae

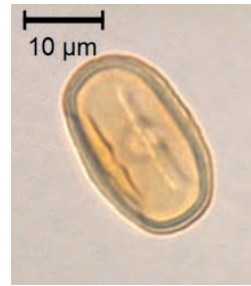

84 Apiaceae psilate

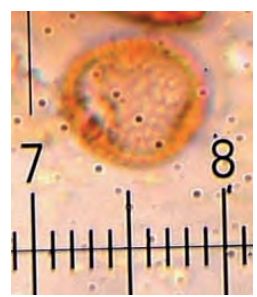

90 Sterculiaceae

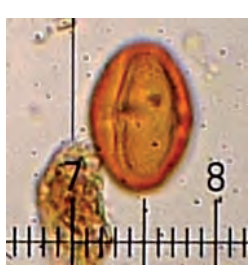

95 Araliaceae spp.

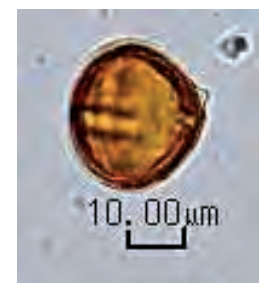

96 Dendropanax Araliaceae 


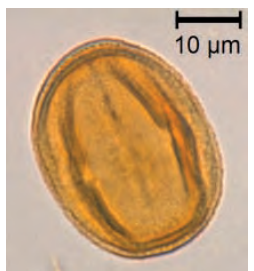

97 Oreopanax

- Araliaceae

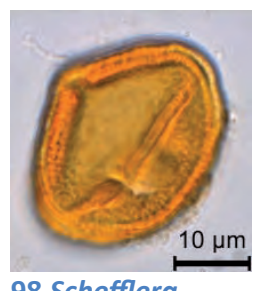

98 Schefflera

- Araliaceae

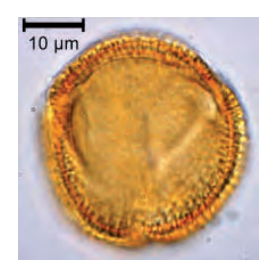

99 Arcytophyllum

- Rubiaceae

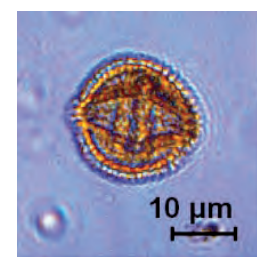

100 Dioicodendron

type - Rubiaceae

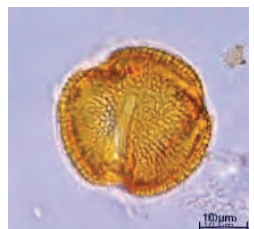

101 Casearia -

Flacourtiaceae

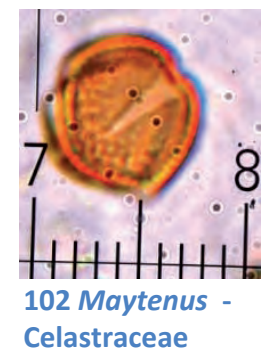

Celastraceae

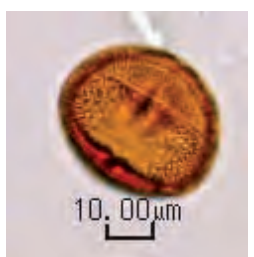

103 Mabea Euphorbiaceae

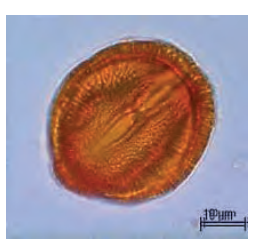

104 Gentianella type

- Gentianaceae

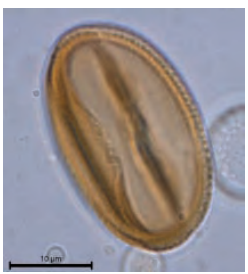

110 Hypericum Clusiaceae

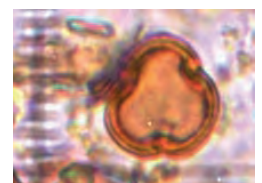

116 Banara -

Flacourtiaceae

115 Apeiba

Malvaceae

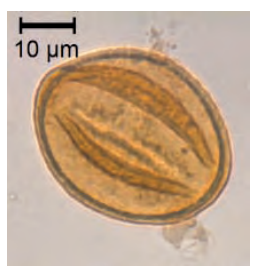

121 Rosaceae spp.

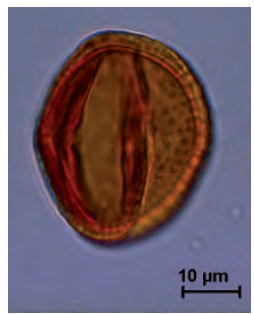

127 Chuquiraga -

Asteraceae
128 Senecio type

- Asteraceae

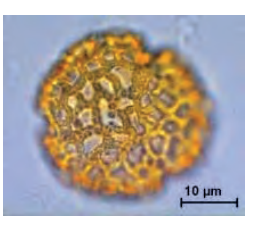

105 Macrocarpaea

- Gentianacae

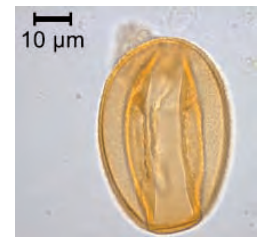

111 Fabaceae reticulate

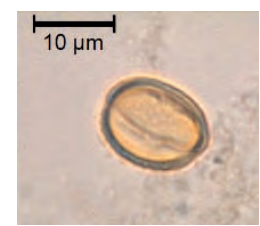

117 Weinmannia

- Cunoniaceae

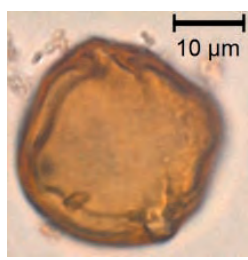

123 Mauria -

Anacardiaceae

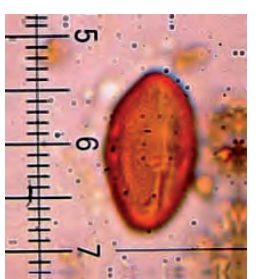

106 Heliocarpus americanus

- Malvaceae

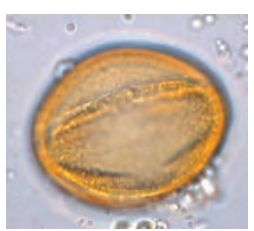

112 Lecythidaceae

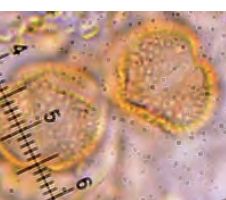

118 Hydrangaea

- Hydrangaeaceae

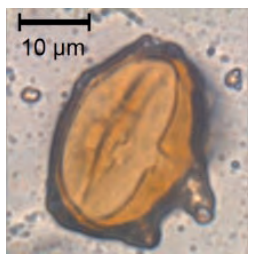

124 Tapirira -

Anacardiaceae

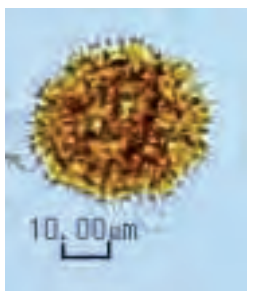

130 Vernonia type

- Asteraceae

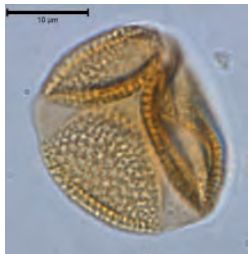

107 Tabebuia

- Bignoniaceae

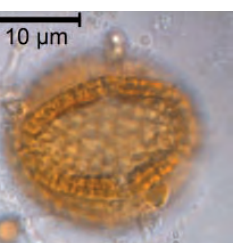

113 Meliosma -

Sabiaceae

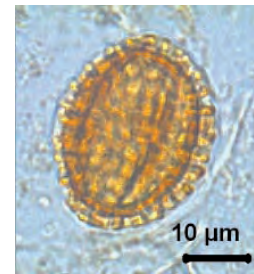

119 Viburnum

- Adoxaceae

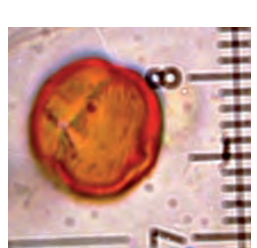

125 Cestrum -

Solanaceae

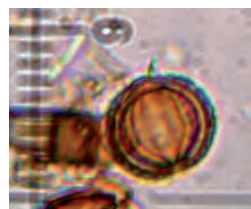

131 Ambrosia type - Asteraceae

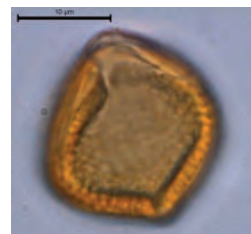

108 Vismia/ Chrysochlamis - Clusiaceae

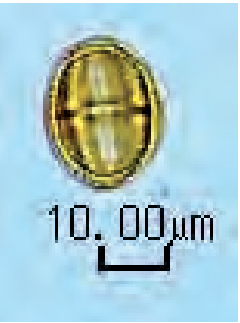

114 Zanthoxylum Rutaceae

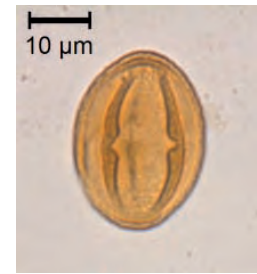

120 Prunus type

- Rosaceae

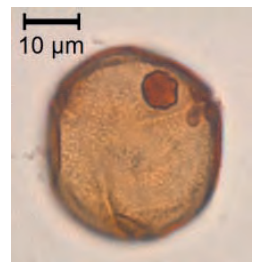

126 Rumex/ Mühlenbeckia -

Polygonaceae

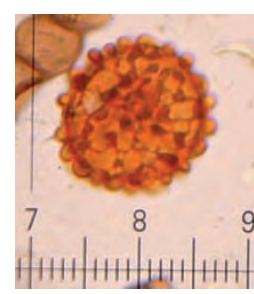

132 Acanthaceae
129 Baccharis type - Asteraceae 


\section{Heterocolporate Bisaccate}

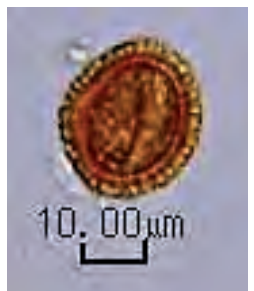

133 Ilex -

Aquifoliaceae

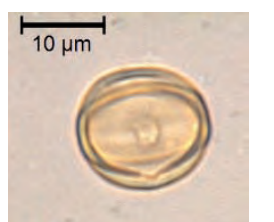

134 Melastomataceae

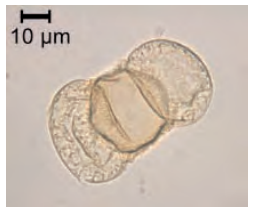

135 Podocarpaceae

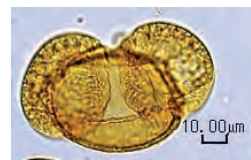

136 Pinus -

Pinaceae

\section{Polyade grains}

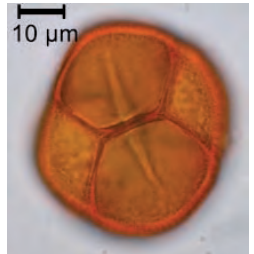

137 Ericaceae

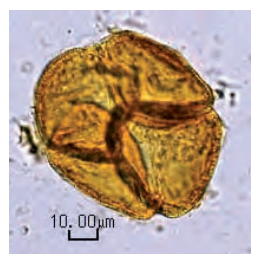

138 Annonaceae

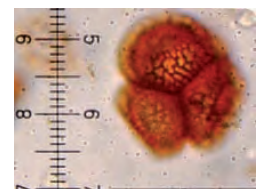

139 Drymis granadensis Winteraceae

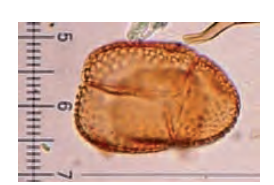

140 Orchidaceae

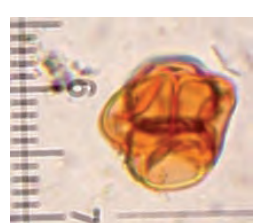

141 Tetrade psilate

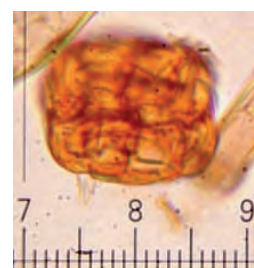

142 Mimosioidae polyade - Fabaceae

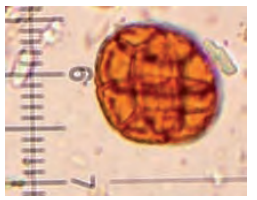

143 Anadenanthera

Morphotype -

Fabaceae

\section{Spores}

\section{Trilete}

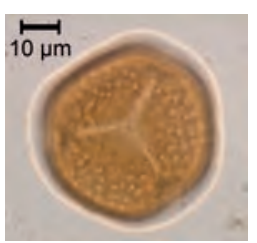

144 Huperzia Lycopodiaceae

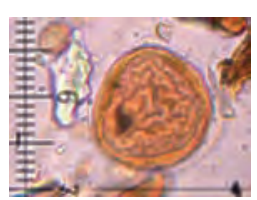

145 Lycopodium cernuum type Lycopodiaceae

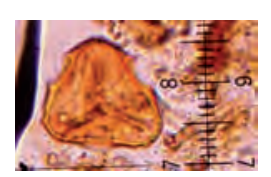

146 Cyathea horrida

- Cyatheaceae

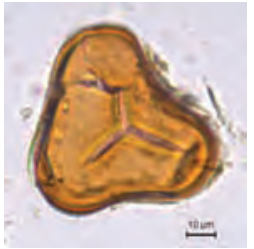

147 Cyathea psilate - Cyatheaceae

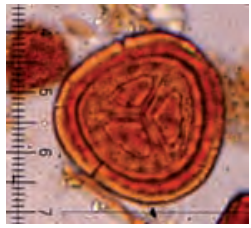

148 Lophosoria quadripinnata - Dicksoniaceae

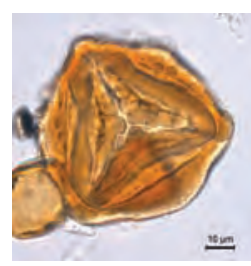

149 Jamesonia - Pteridaceae

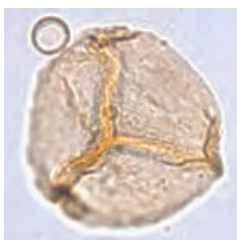

를

150 Hymenophyllum 151 Selaginella

- Hymenophyllaceae - Selaginellaceae

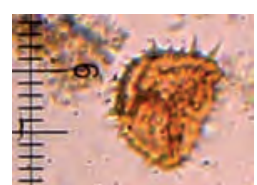




\section{Appendix 5: List of all recorded tree taxa of the Matrix-plots (by Jürgen Homeier)}

Family/Pollen family group

Actinidiaceae

Adoxaceae

Alzateacae

Anacardiaceae

Anacardiaceae

Annonaceae

Annonaceae

Annonaceae

Annonaceae

Apocynaceae

Aquifoliaceae

Araliaceae

Araliaceae

Araliaceae

Arecaceae

Arecaceae

Arecaceae

Asteraceae

Asteraceae

Asteraceae

Asteraceae

Asteraceae

Bignoniaceae

Boraginaceae

Boraginaceae

Brunelliaceae

Burseraceae

Burseraceae

Cannabaceae

Capparaceae

Cardiopteridaceae

Celastraceae

Celastraceae

Chloranthaceae

Chrysobalanaceae

Chrysobalanaceae

Clethraceae

Clusiaceae/Hypericaceae

Clusiaceae/Hypericaceae

Clusiaceae/Hypericaceae

Clusiaceae/Hypericaceae

\begin{tabular}{|c|c|}
\hline Genus & Number of species \\
\hline Saurauia & 4 \\
\hline Viburnum & 2 \\
\hline Alzatea & 1 \\
\hline Mauria & 1 \\
\hline Tapirira & 1 \\
\hline Annona & 2 \\
\hline Cremastosperma & 1 \\
\hline Guatteria & 4 \\
\hline Klarobelia & 1 \\
\hline Aspidosperma & 1 \\
\hline Ilex & 8 \\
\hline Dendropanax & 2 \\
\hline Oreopanax & 3 \\
\hline Schefflera & 3 \\
\hline Cerolylon & 2 \\
\hline Euterpe & 1 \\
\hline Prestoea & 1 \\
\hline Baccharis & 1 \\
\hline Critoniopsis & 3 \\
\hline Gynoxys & 2 \\
\hline Lepidaploa & 1 \\
\hline Piptocoma & 1 \\
\hline Tabebuya & 1 \\
\hline Cordia & 1 \\
\hline Tournefortia & 1 \\
\hline Brunellia & 1 \\
\hline Dacryodes & 3 \\
\hline Trattinnickia & 1 \\
\hline Trema & 1 \\
\hline Capparis & 1 \\
\hline Dendrobangia & 1 \\
\hline Maytenus & 2 \\
\hline Zinowiewia & 1 \\
\hline Hedydosmum & 6 \\
\hline Hirtella & 1 \\
\hline Licania & 3 \\
\hline Clethra & 2 \\
\hline Chrysochlamys & 2 \\
\hline Clusia & 5 \\
\hline Garcinia & 1 \\
\hline Tovomita & 1 \\
\hline
\end{tabular}




\begin{tabular}{|c|c|}
\hline Clusiaceae/Hypericaceae & Vismia \\
\hline Cunoniaceae & Weinmannia \\
\hline Cyatheaceae & Alsophila \\
\hline Cyatheaceae & Cyathea \\
\hline Dicksoniaceae & Dicksonia \\
\hline Elaeocarpaceae & Sloanea \\
\hline Ericaceae & Bejaria \\
\hline Ericaceae & Cavendishia \\
\hline Erythroxylaceae & Erythroxylum \\
\hline Euphorbiaceae & Alchornea \\
\hline Euphorbiaceae & Alchorneopsis \\
\hline Euphorbiaceae & Mabea \\
\hline Euphorbiaceae & Richeria \\
\hline Euphorbiaceae & Sapium \\
\hline Fabaceae & Dussia \\
\hline Flacourtiaceae & Banara \\
\hline Flacourtiaceae & Casearia \\
\hline Flacourtiaceae & Hasseltia \\
\hline Hernandiaceae & indet \\
\hline Lacistemataceae & Lozania \\
\hline Lauraceae & Aiouea \\
\hline Lauraceae & Aniba \\
\hline Lauraceae & Beilschmiedia \\
\hline Lauraceae & Cinnamomum \\
\hline Lauraceae & Endlicheria \\
\hline Lauraceae & Licaria \\
\hline Lauraceae & Nectandra \\
\hline Lauraceae & Ocotea \\
\hline Lauraceae & Persea \\
\hline Lauraceae & Pleurothyrium \\
\hline Lauraceae & Rhodostemonodapne \\
\hline Lauraceae & indet \\
\hline Lecythidaceae & Eschweilera \\
\hline Lecythidaceae & Grias \\
\hline Lecythidaceae & Gustavia \\
\hline Loranthaceae & Gaiadendron \\
\hline Malpighiaceae & Byrsonima \\
\hline Melastomataceae/Combretaceae & Terminalia \\
\hline Melastomataceae/Combretaceae & Axinaea \\
\hline Melastomataceae/Combretaceae & Brachyotum \\
\hline Melastomataceae/Combretaceae & Centronia \\
\hline Melastomataceae/Combretaceae & Graffenrieda \\
\hline Melastomataceae/Combretaceae & Meriania \\
\hline Melastomataceae/Combretaceae & Miconia \\
\hline Melastomataceae/Combretaceae & Tibouchina \\
\hline Meliaceae & Cedrela \\
\hline Meliaceae & Guarea \\
\hline
\end{tabular}




\begin{tabular}{|c|}
\hline Meliaceae \\
\hline Meliaceae \\
\hline Mimosaceae \\
\hline Mimosaceae \\
\hline Monimiaceae \\
\hline Moraceae/Urticaceae \\
\hline Moraceae/Urticaceae \\
\hline Moraceae/Urticaceae \\
\hline Moraceae/Urticaceae \\
\hline Moraceae/Urticaceae \\
\hline Moraceae/Urticaceae \\
\hline Moraceae/Urticaceae \\
\hline Moraceae/Urticaceae \\
\hline Moraceae/Urticaceae \\
\hline Moraceae/Urticaceae \\
\hline Moraceae/Urticaceae \\
\hline Moraceae/Urticaceae \\
\hline Moraceae/Urticaceae \\
\hline Moraceae/Urticaceae \\
\hline Moraceae/Urticaceae \\
\hline Myricaceae \\
\hline Myristicaceae \\
\hline Myristicaceae \\
\hline Myrtaceae \\
\hline Myrtaceae \\
\hline Myrtaceae \\
\hline Myrtaceae \\
\hline Myrtaceae \\
\hline Nyctaginaceae \\
\hline Nyctaginaceae \\
\hline Olacaceae \\
\hline Pentaphylacaceae \\
\hline Phyllanthaceae \\
\hline Piperaceae \\
\hline Podocarpaceae \\
\hline Podocarpaceae \\
\hline Polygalaceae \\
\hline Polygonaceae \\
\hline Primulaceae \\
\hline Primulaceae \\
\hline Primulaceae \\
\hline Proteaceae \\
\hline Proteaceae \\
\hline Proteaceae \\
\hline Rosaceae \\
\hline Rosaceae \\
\hline Rubiaceae \\
\hline
\end{tabular}

Ruagea 2

Trichilia 2

Abarema 1

Inga 10

Mollinedia 1

Cecropia 2

Pourouma 1

Batocarpus 1

Brosimum 1

Clarisia 2

Ficus 7

Helicostylis 2

Morus 1

Naucleopsis 1

Perebea 1

Poulsenia 1

Pseudolmedia 3

Sorocea 1

Boehmeria 1

Myriocarpa 1

Myrica 1

Otoba 1

Virola 2

Calyptranthes 2

Eugenia 7

Myrcia 6

Myrcianthes 1

Siphoneugena 1

Neea 2

Pisonia 1

Heisteria 2

Ternstroemia 2

Hieronyma 4

Piper 7

Podocarpus 1

Prumnopitys 1

Monnina 1

Triplaris 1

Cybianthus 1

Geissanthus 2

Myrsine 2

Euplassa 1

Panopsis 1

Roupala 2

Hesperomeles 1

Prunus 3

Alibertia 1 


\begin{tabular}{|c|}
\hline Rubiaceae \\
\hline Rubiaceae \\
\hline Rubiaceae \\
\hline Rubiaceae \\
\hline Rubiaceae \\
\hline Rubiaceae \\
\hline Rubiaceae \\
\hline Rubiaceae \\
\hline Rubiaceae \\
\hline Rubiaceae \\
\hline Rubiaceae \\
\hline Rubiaceae \\
\hline Rubiaceae \\
\hline Rubiaceae \\
\hline Rubiaceae \\
\hline Rubiaceae \\
\hline Rubiaceae \\
\hline Rutaceae \\
\hline Sabiaceae \\
\hline Sabiaceae \\
\hline Sapindaceae \\
\hline Sapindaceae \\
\hline Sapindaceae \\
\hline Sapotaceae \\
\hline Sapotaceae \\
\hline Sapotaceae \\
\hline Simaroubaceae \\
\hline Siparunaceae \\
\hline Solanaceae \\
\hline Solanaceae \\
\hline Solanaceae \\
\hline Solanaceae \\
\hline Staphyleaceae \\
\hline Staphyleaceae \\
\hline Styracaceae \\
\hline Symplocaceae \\
\hline Theaceae \\
\hline Theaceae \\
\hline Thymelaceae \\
\hline Tiliaceae \\
\hline Tiliaceae \\
\hline Verbenaceae \\
\hline Violaceae \\
\hline Winterace \\
\hline
\end{tabular}

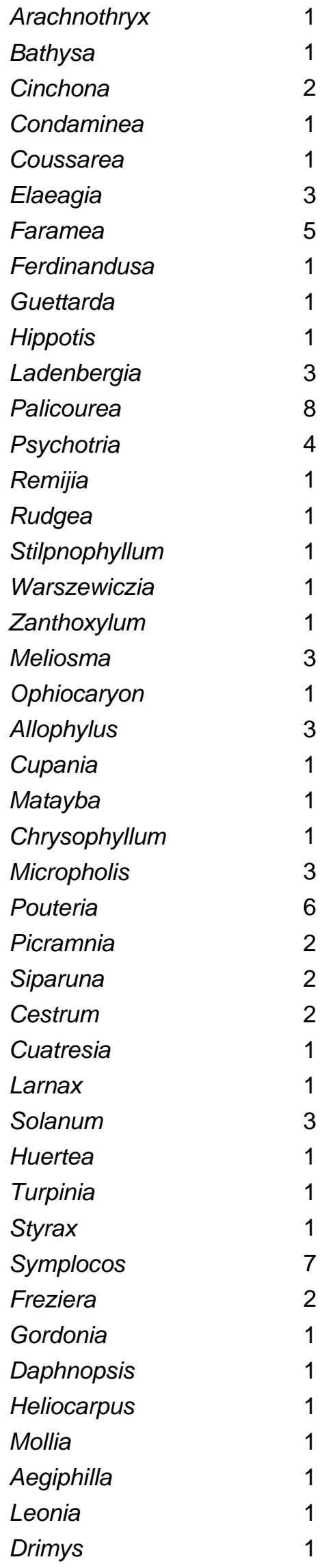


Appendix 6: Complete pollen diagrams 
Appendix 6.1: Complete pollen diagram of the Tres Lagunas sediment record 


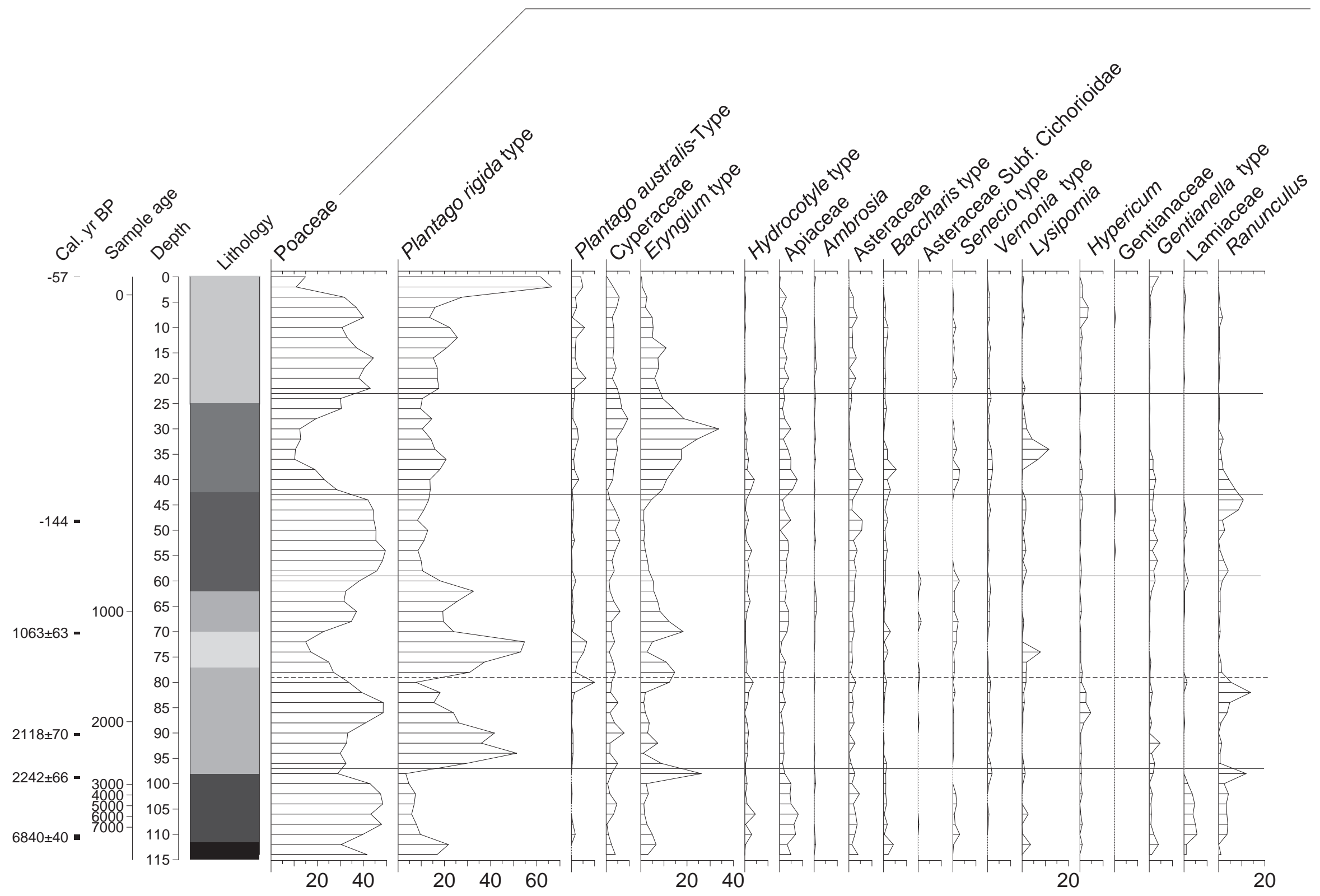




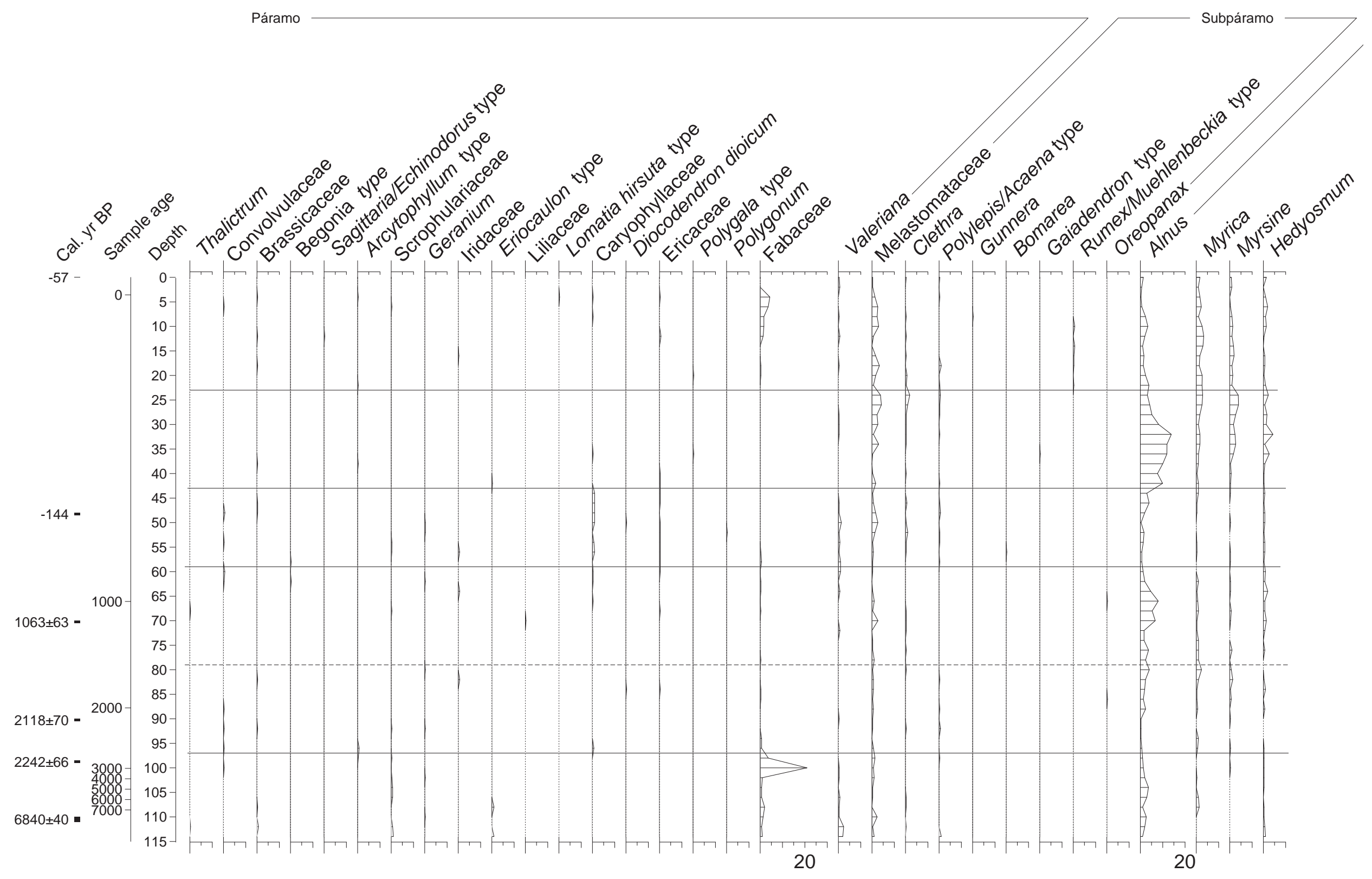




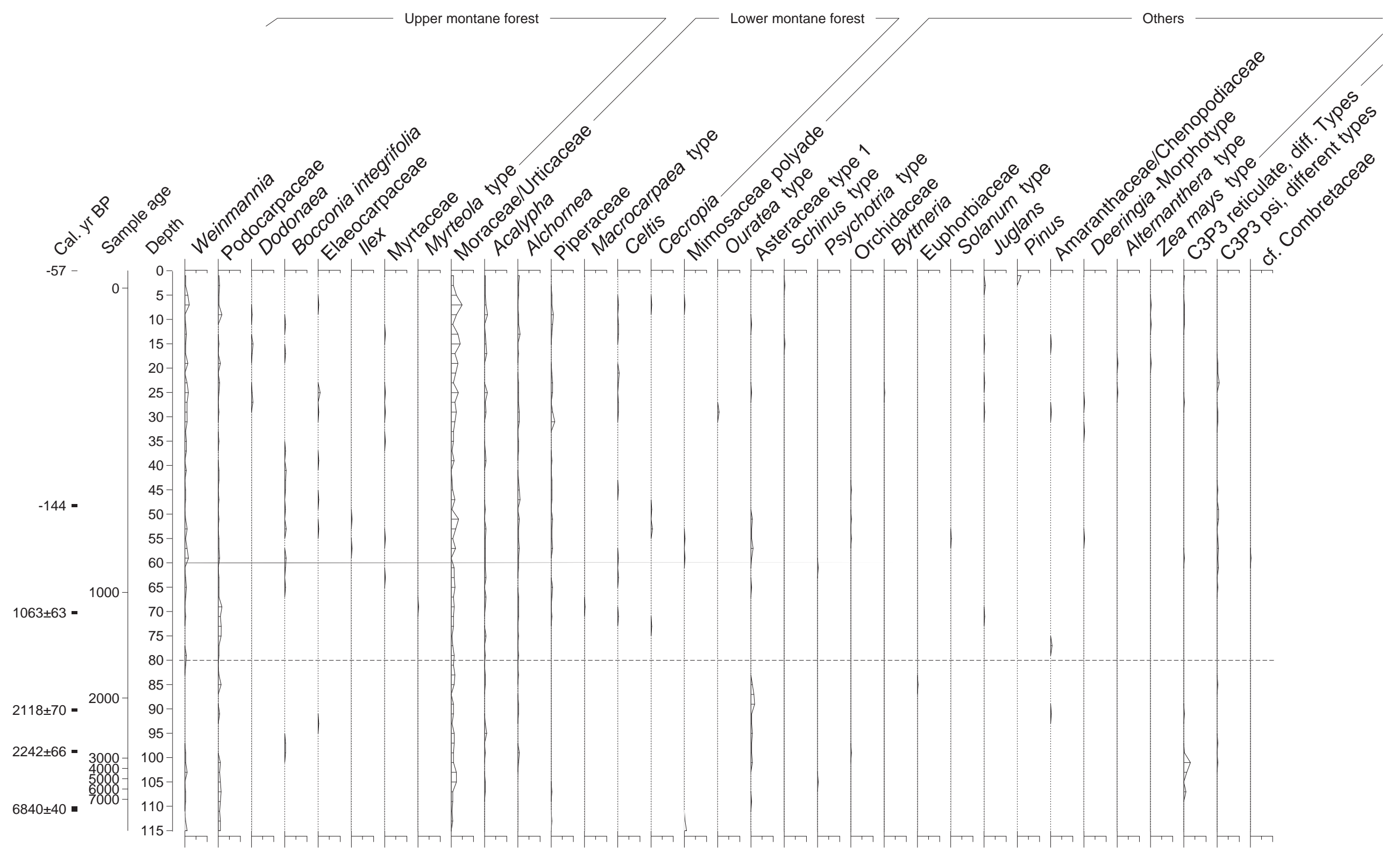




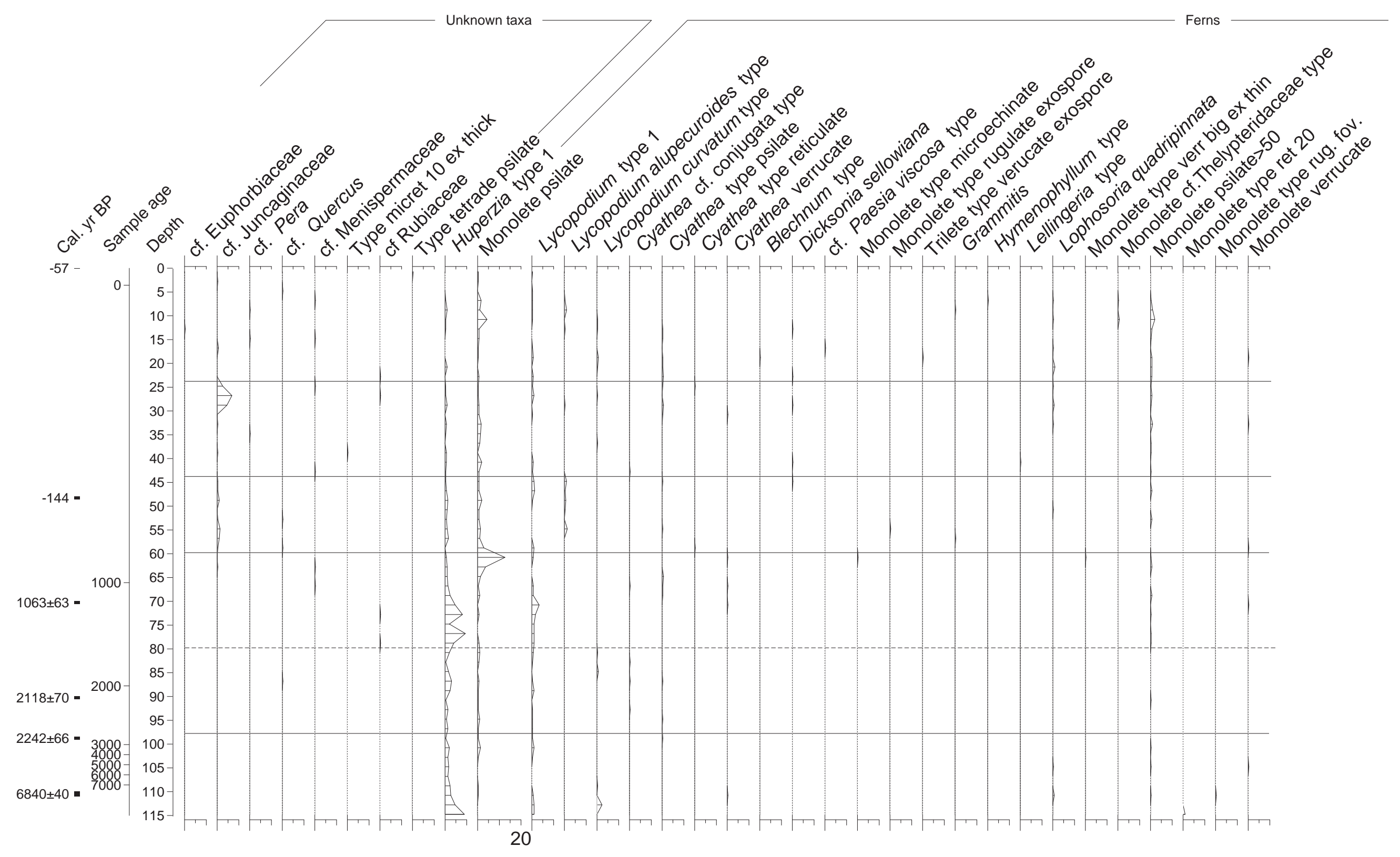




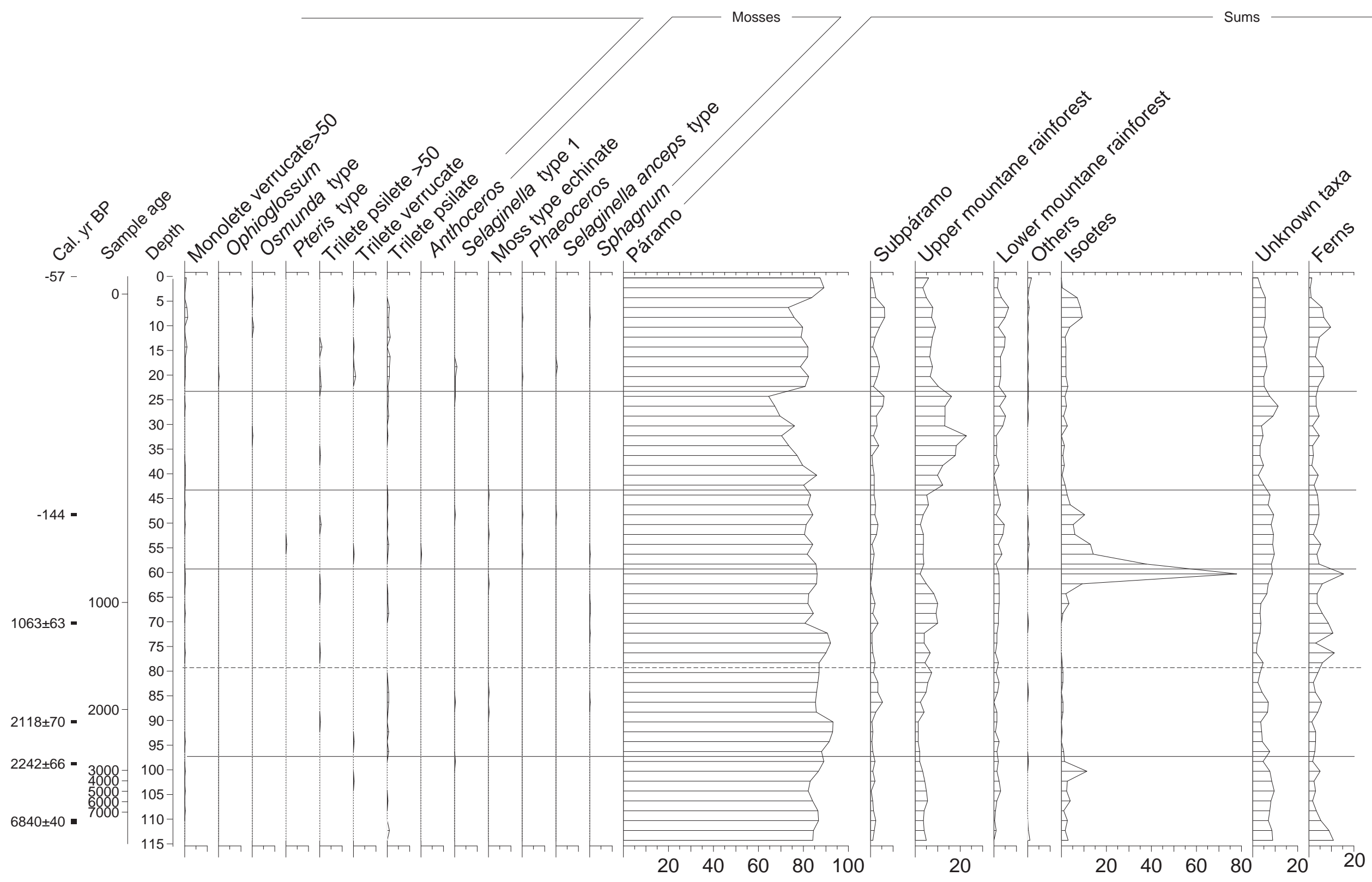




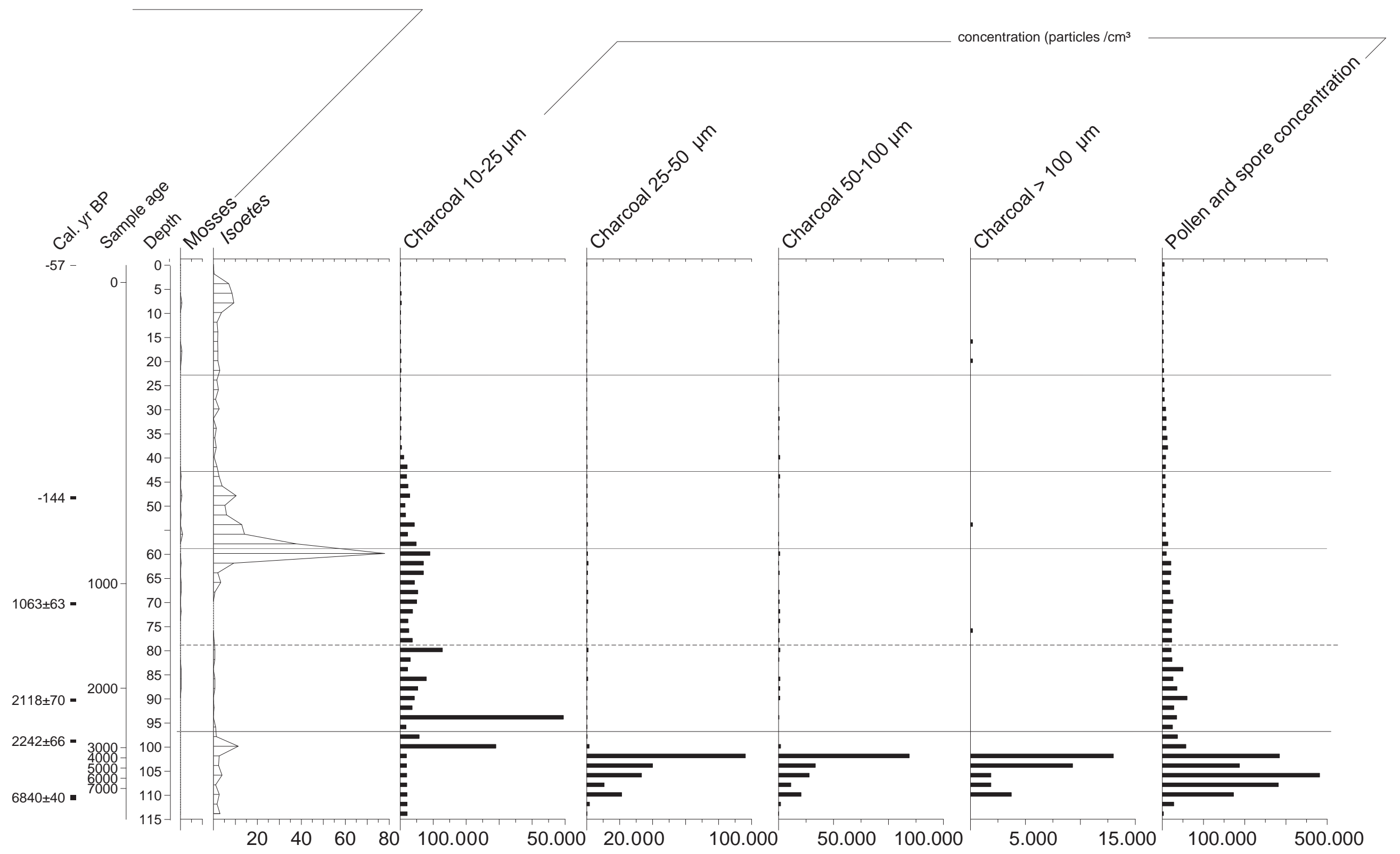




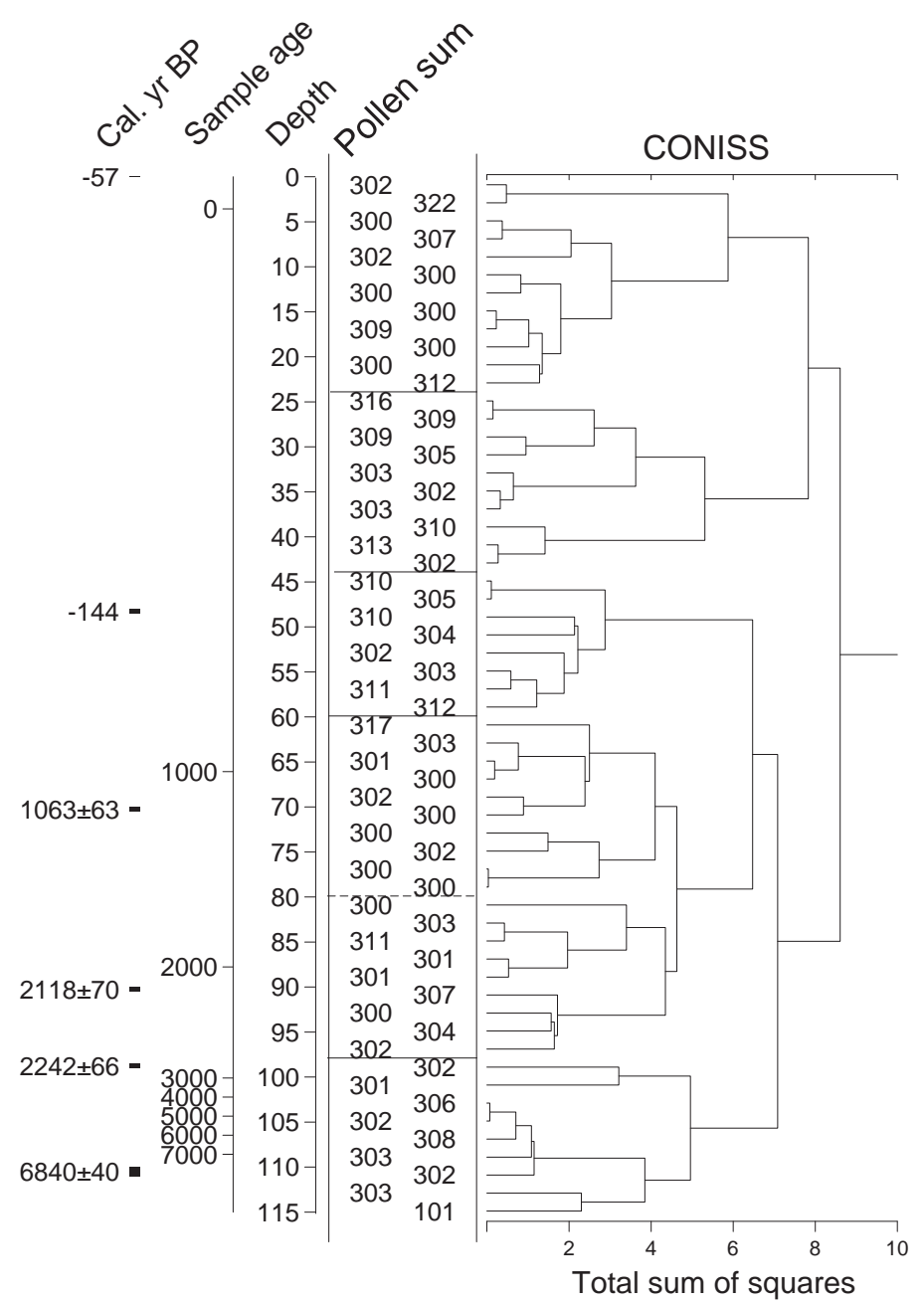


Appendix 6.2: Complete pollen diagram for the modern pollen rain record Bombuscaro 2009-2012 


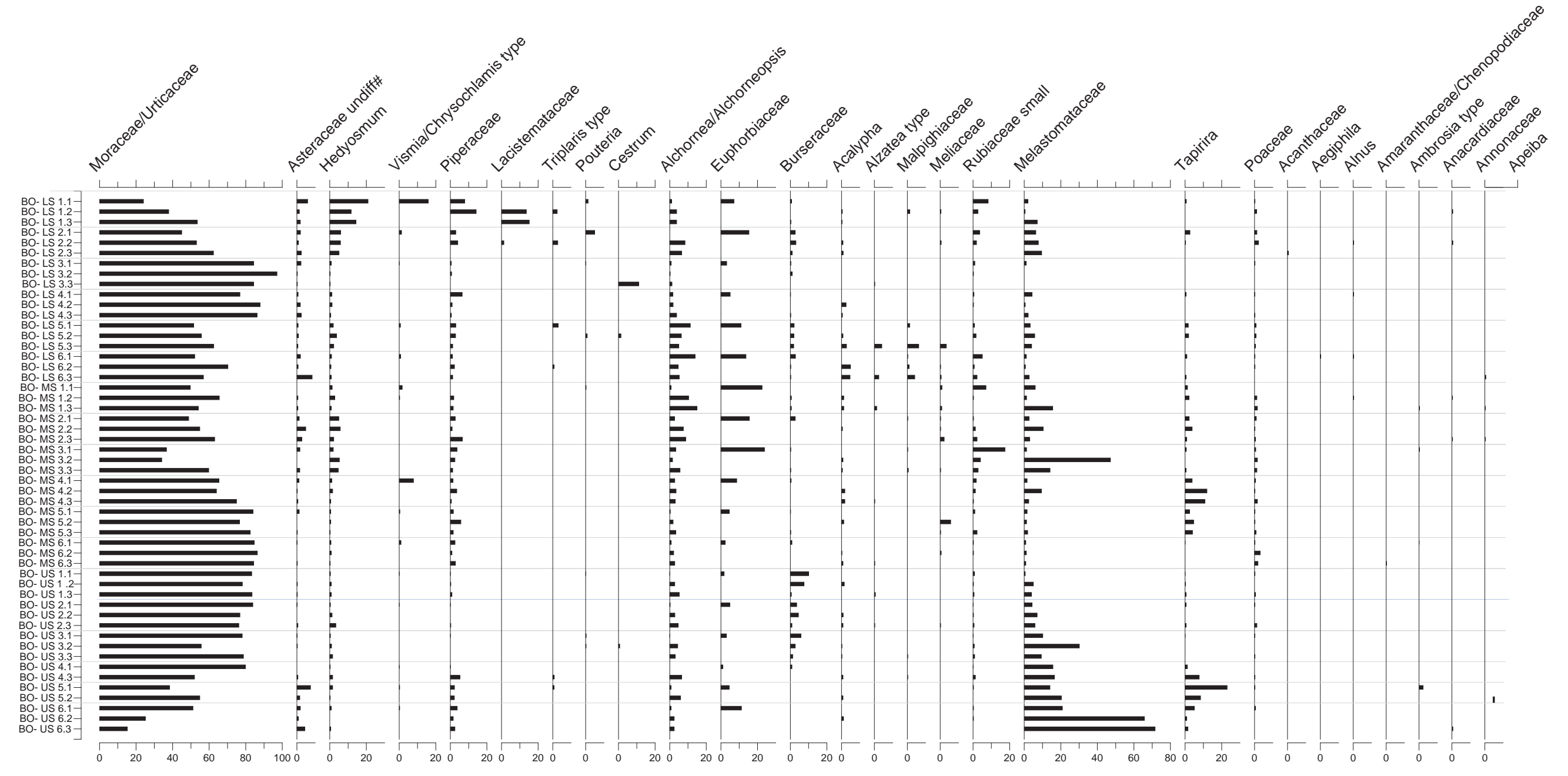




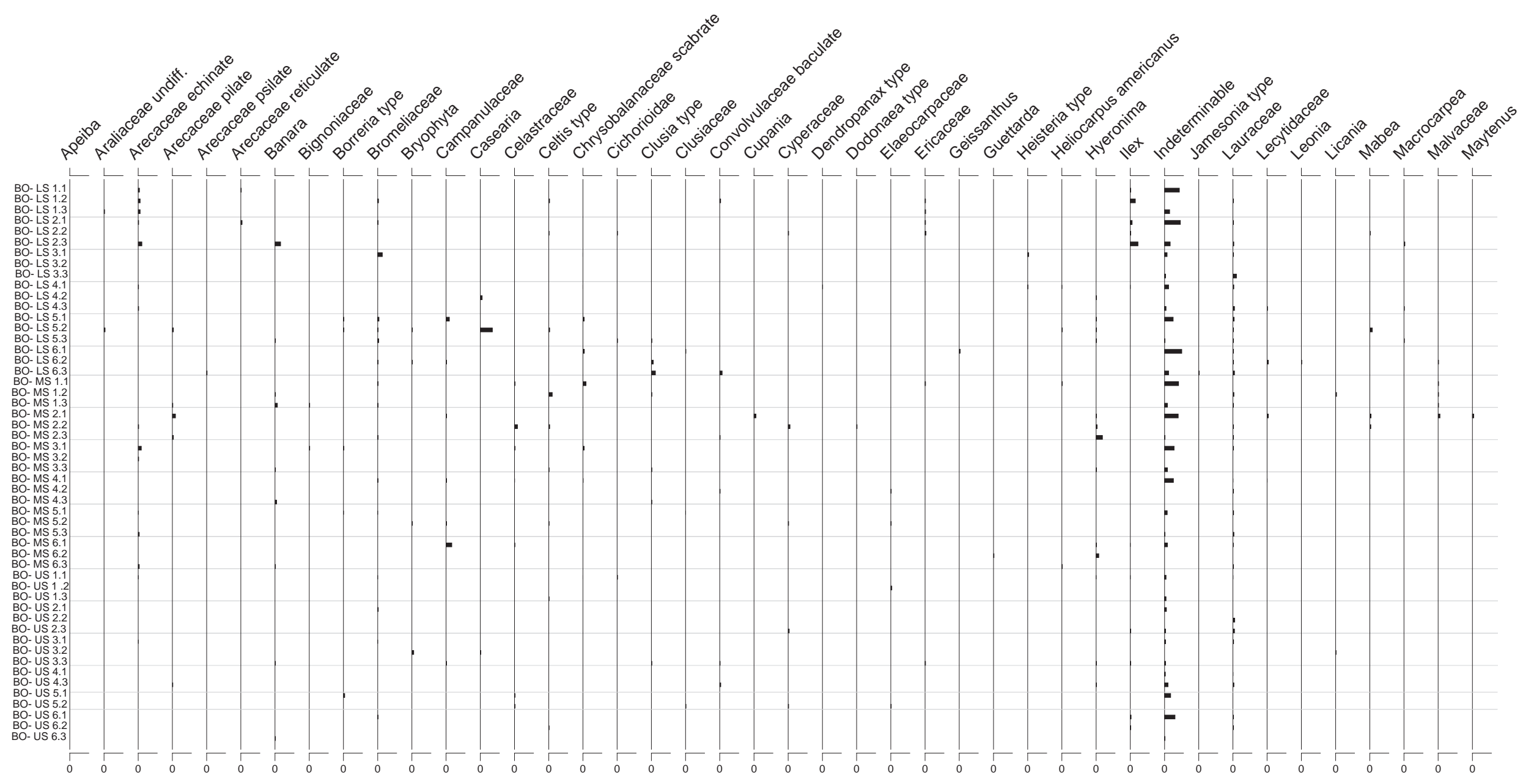


$\stackrel{\infty}{\sim}$

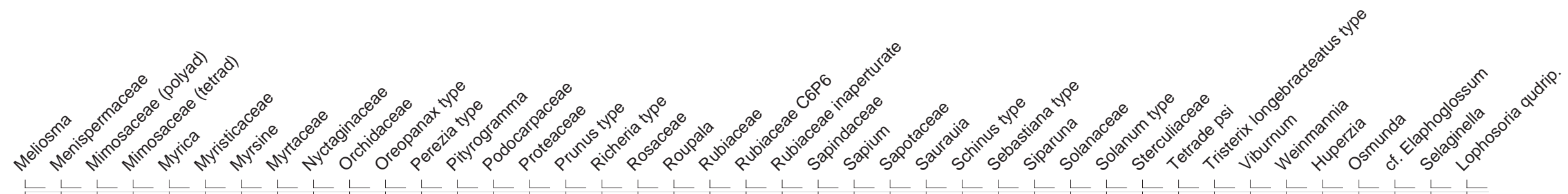




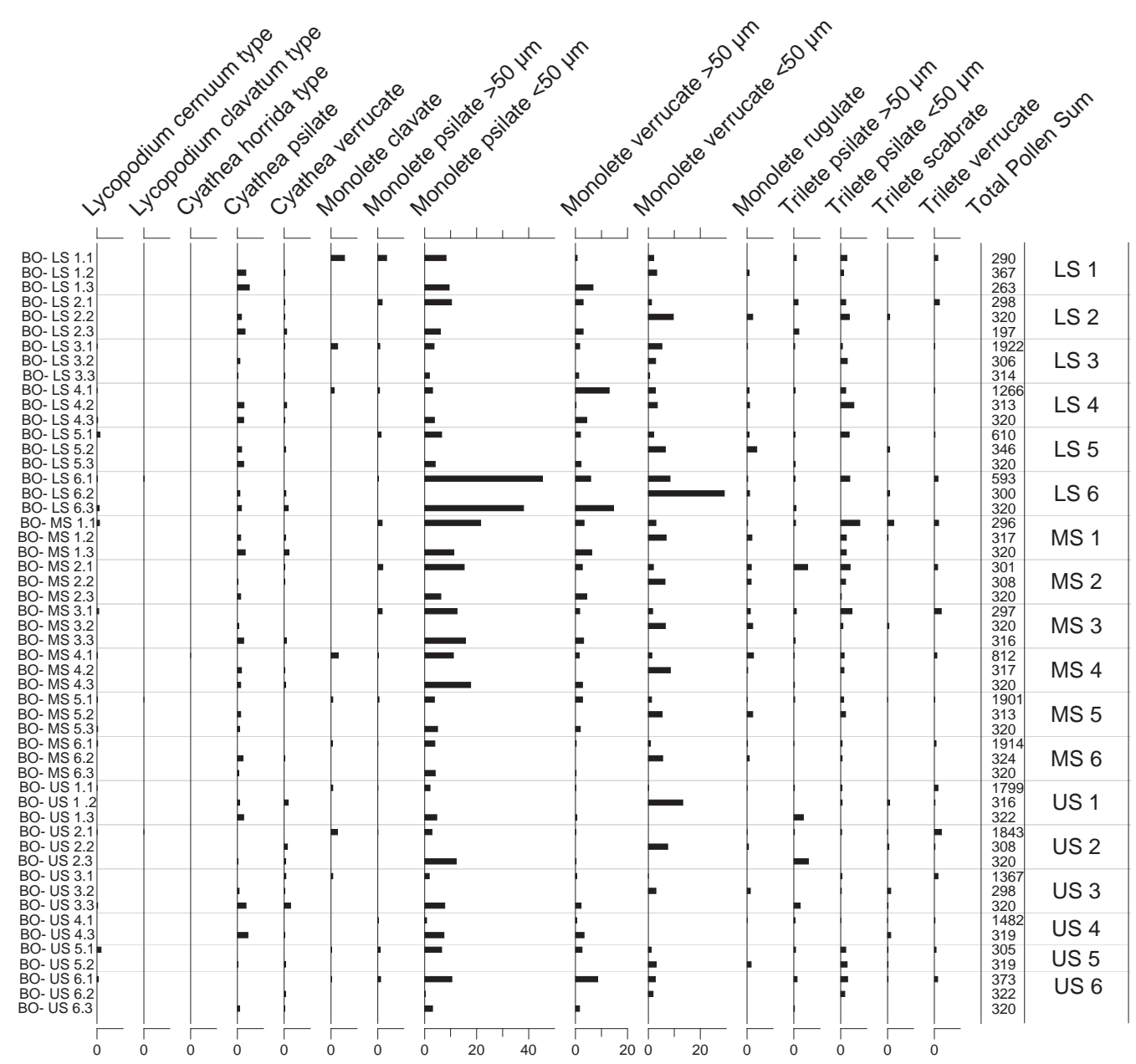


Appendix 6.3: Complete pollen diagram for the modern pollen rain record San Francisco 20092012 


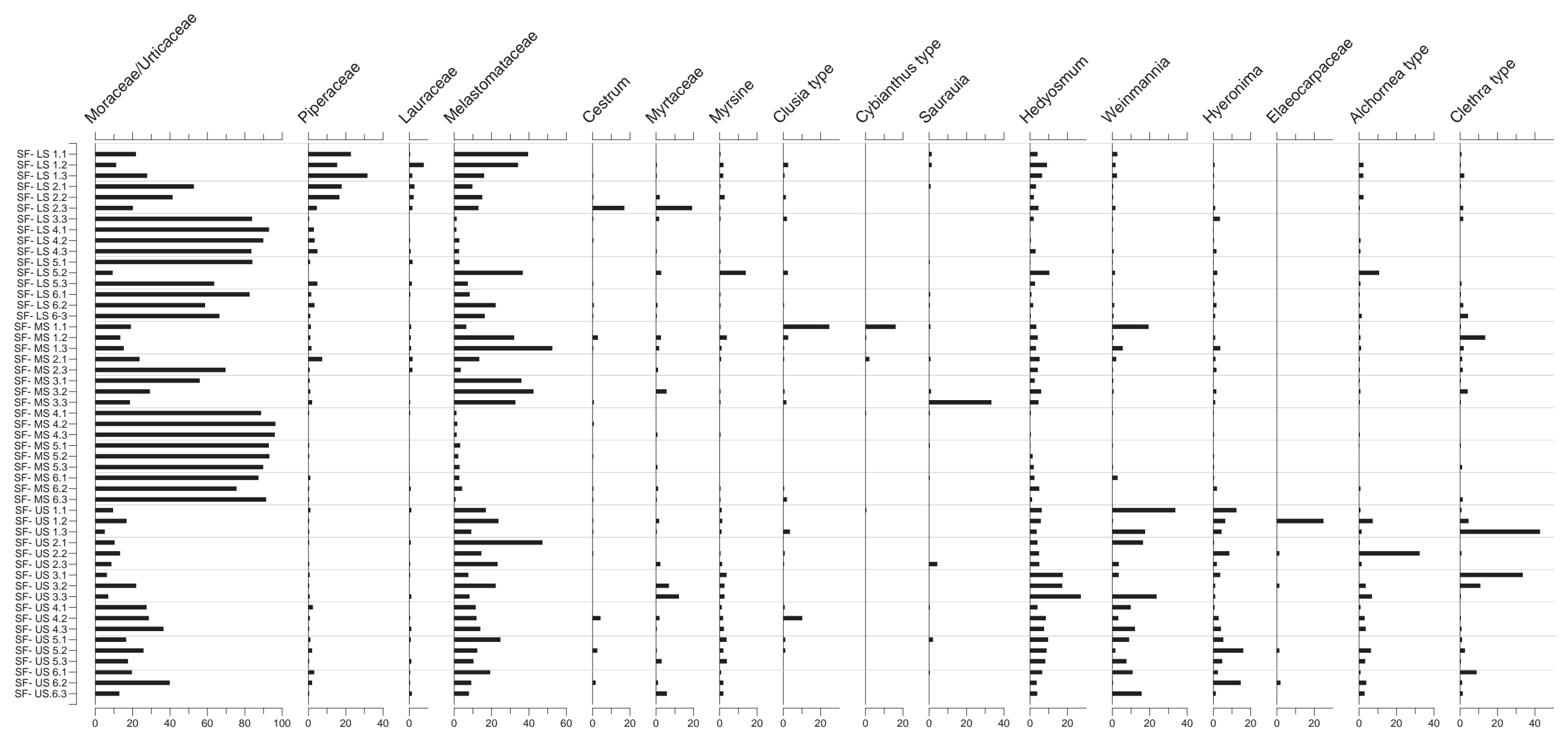




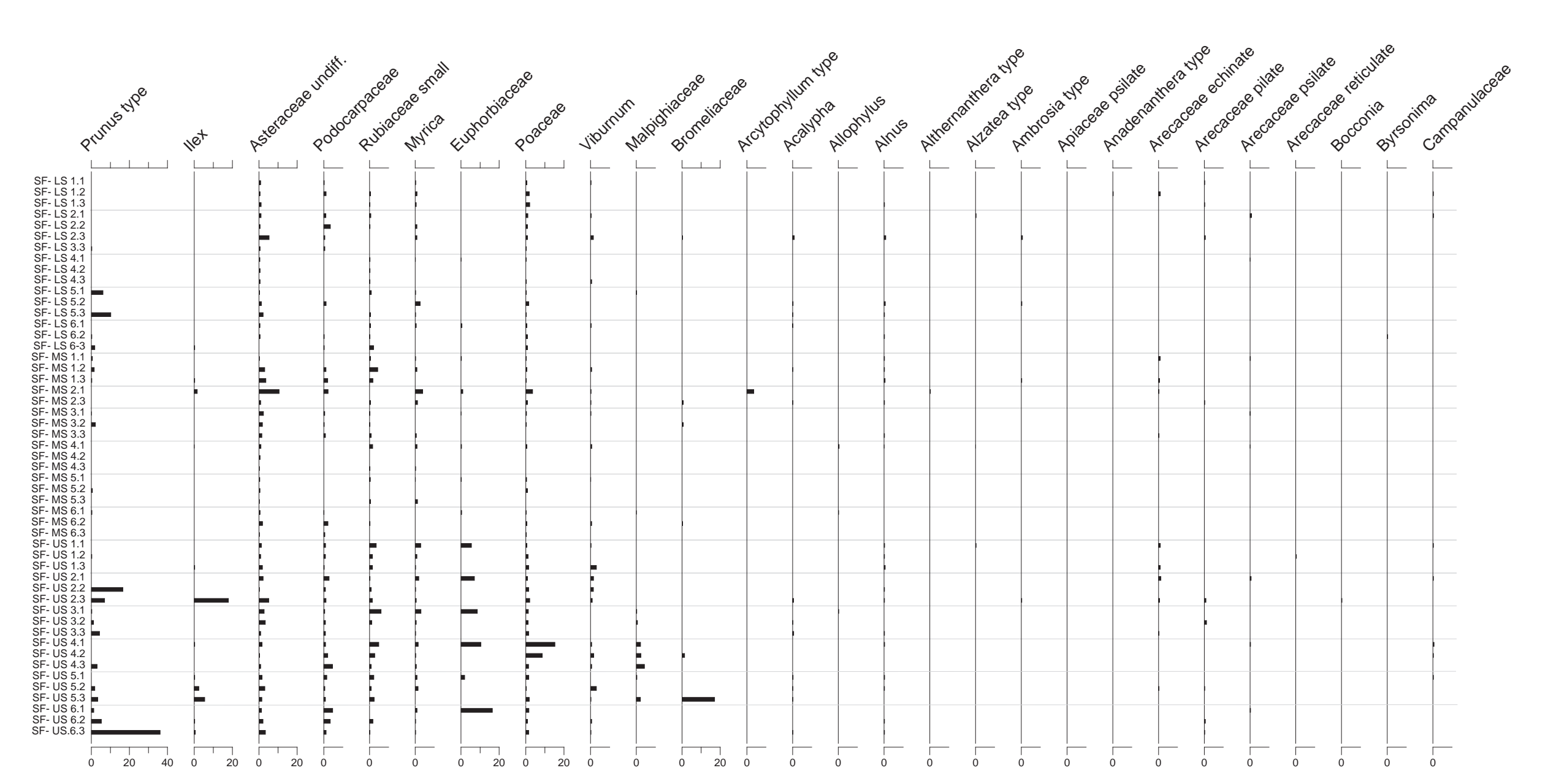




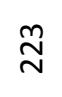

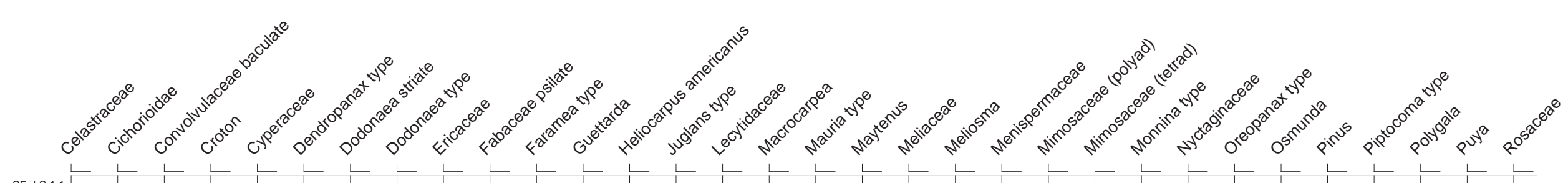




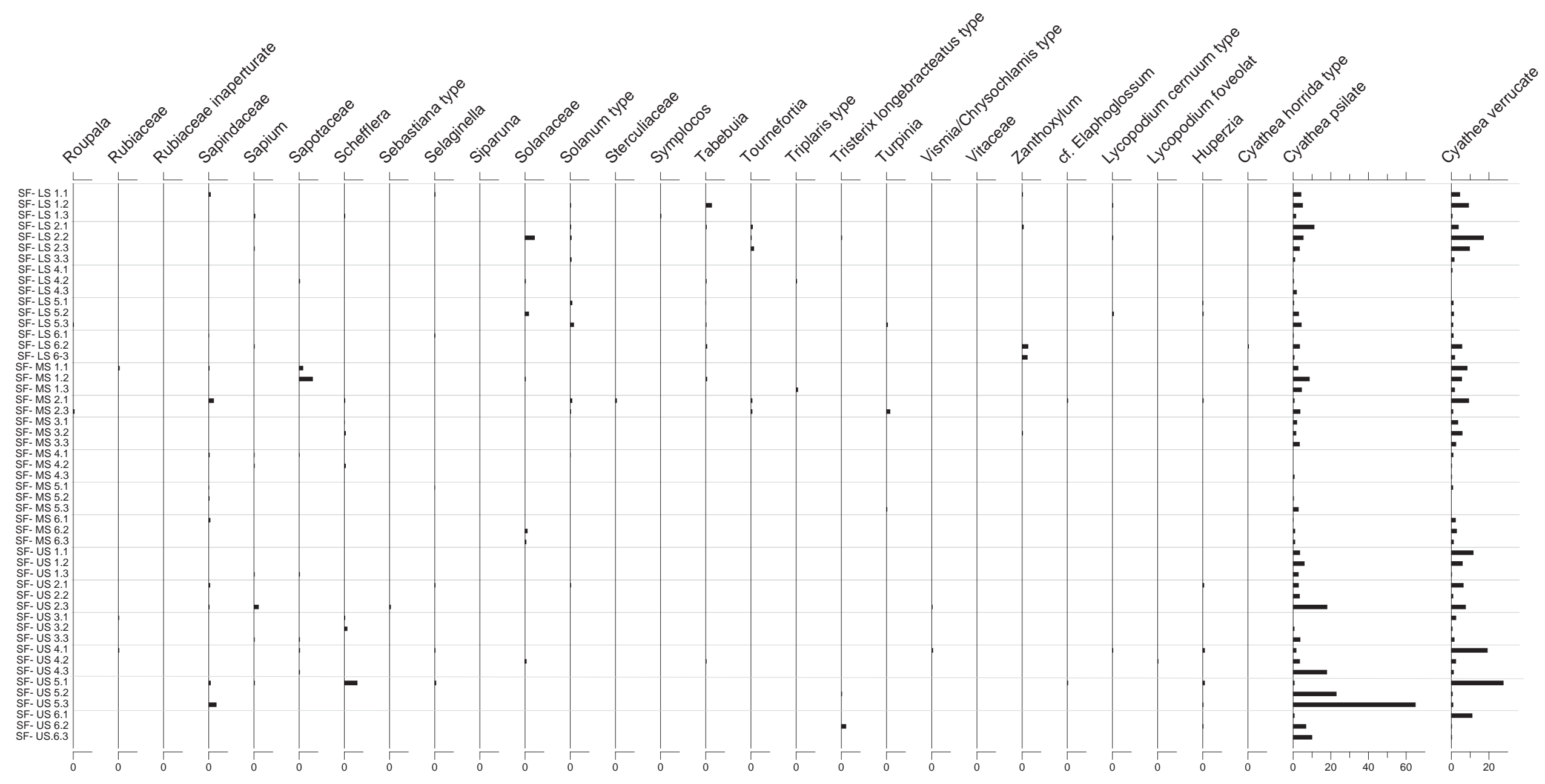




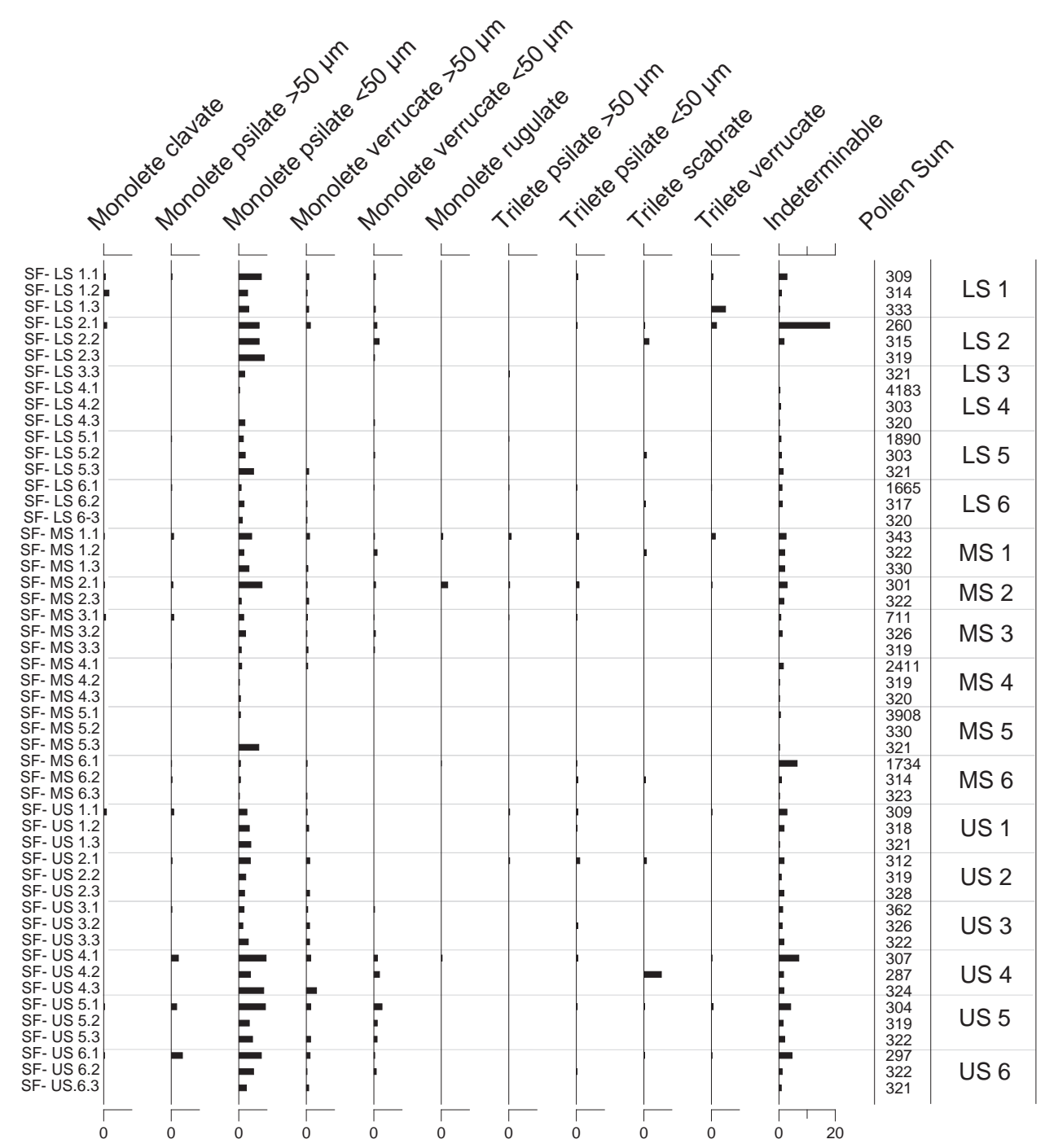


Appendix 6.4: Complete pollen diagram for the modern pollen rain record Cajanuma 2009-2012 


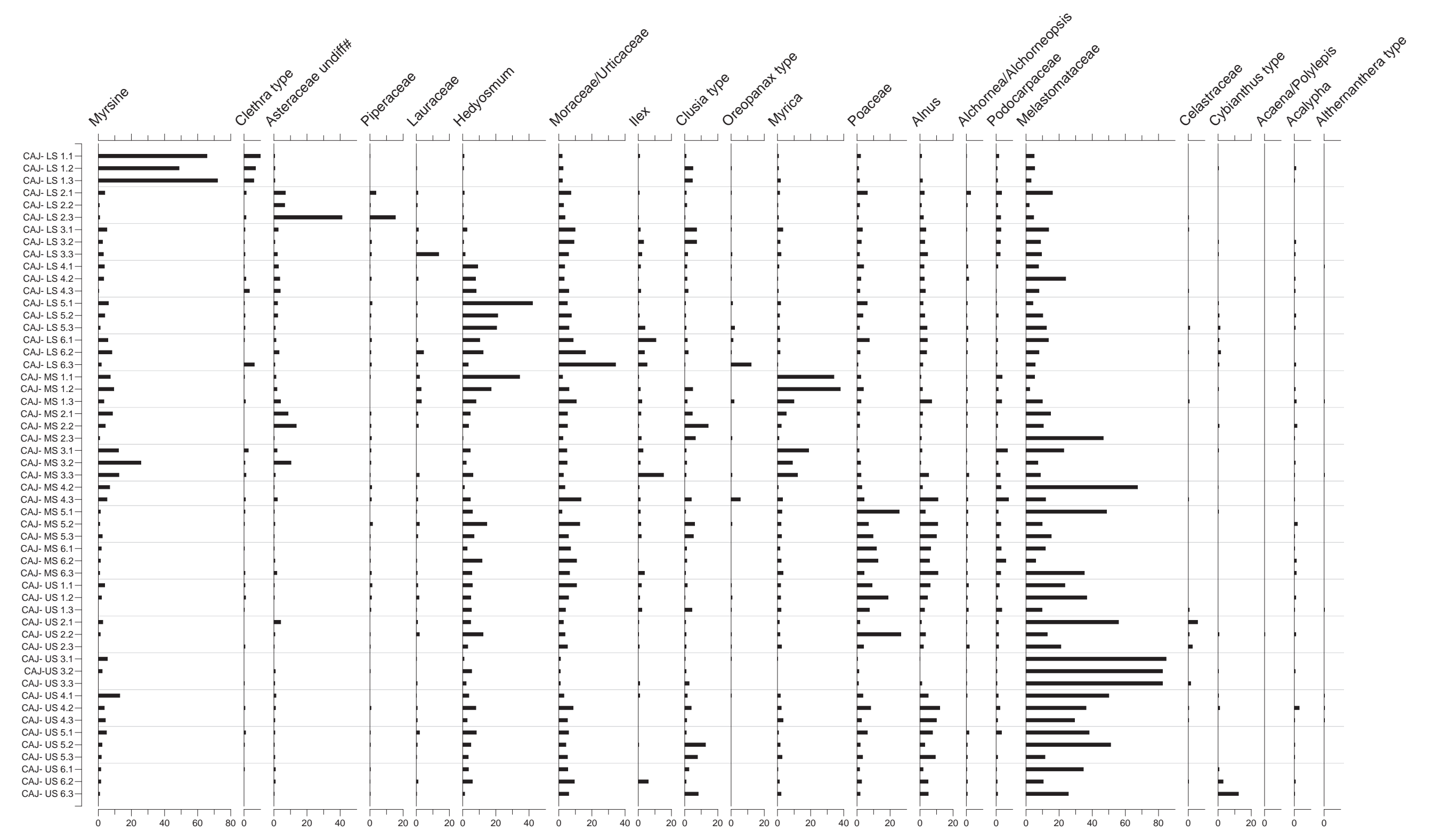




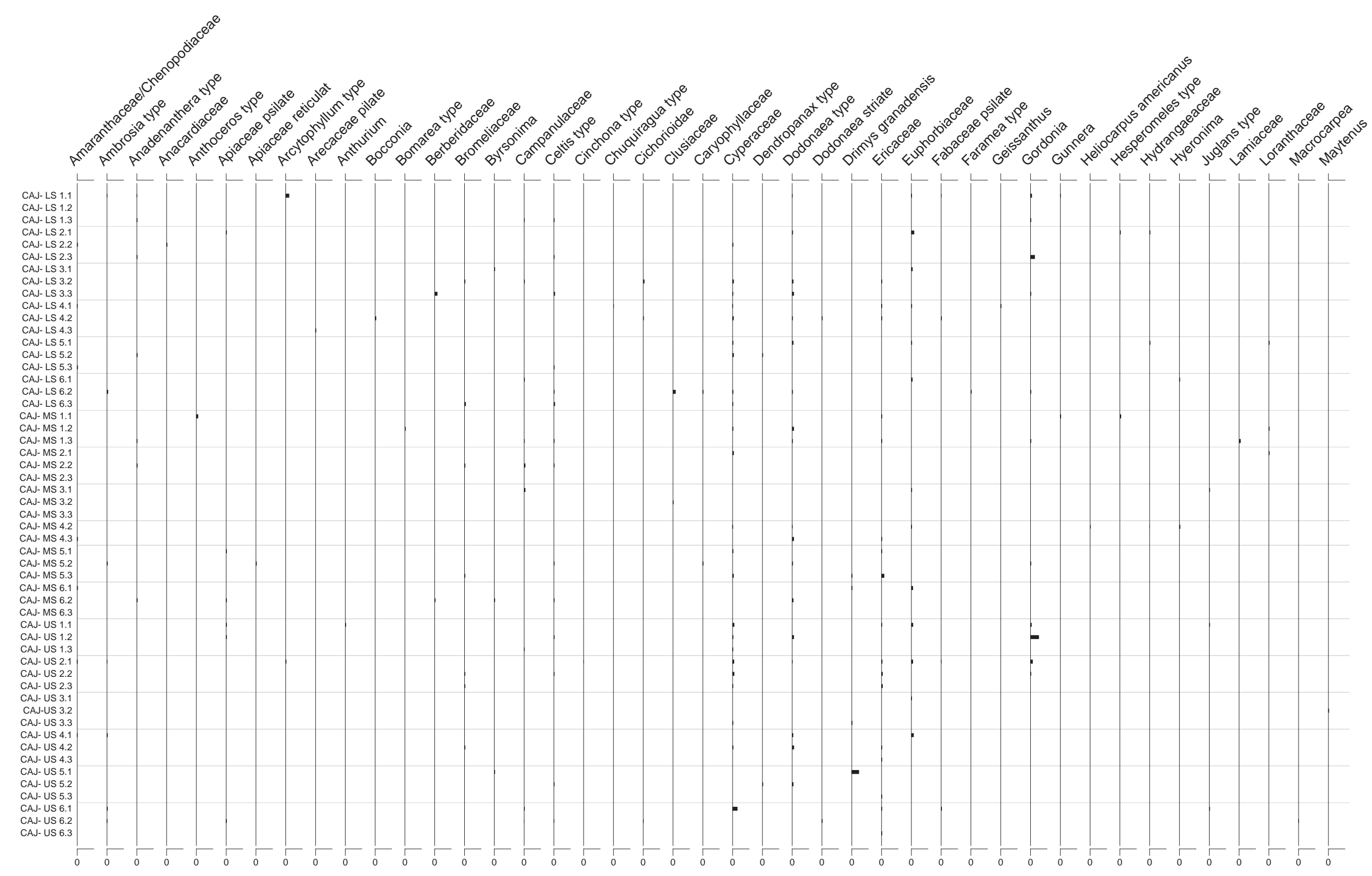


ส

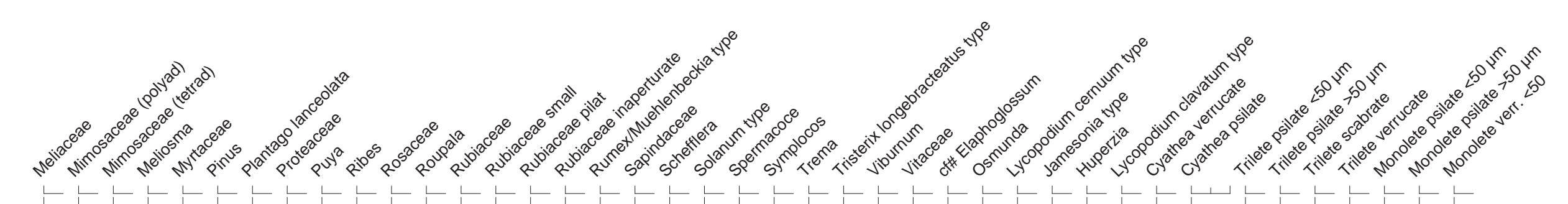




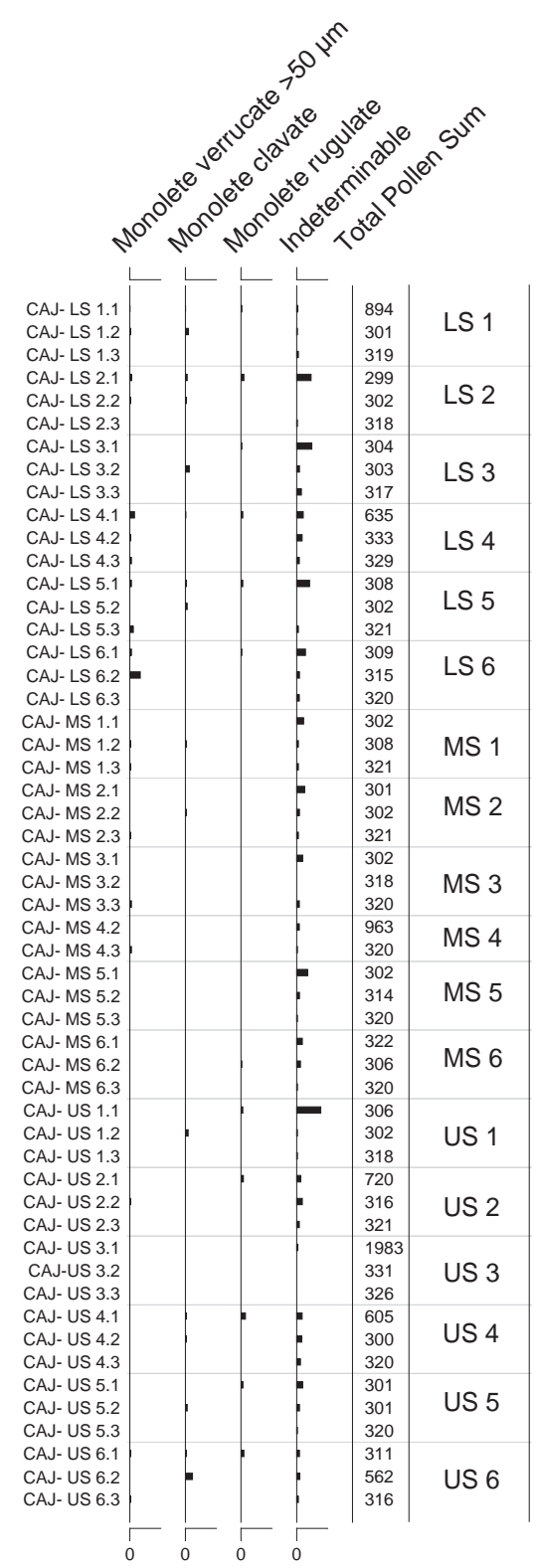


Appendix 6.5: Complete pollen diagram for the modern pollen rain collected with four different trapping media (Behling traps, modified Oldfield traps, Reference traps and surface soil samples) 2010-2011 


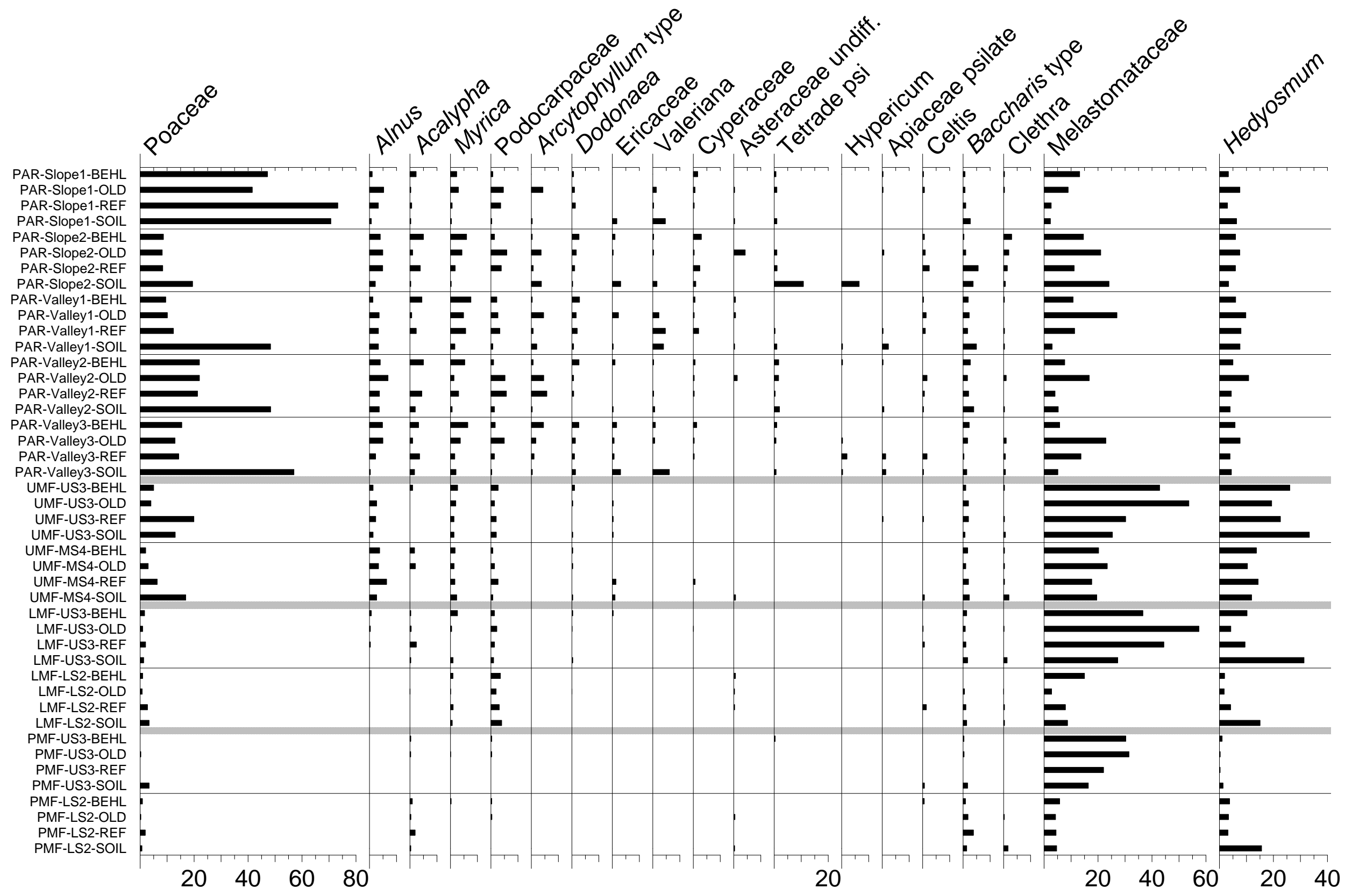




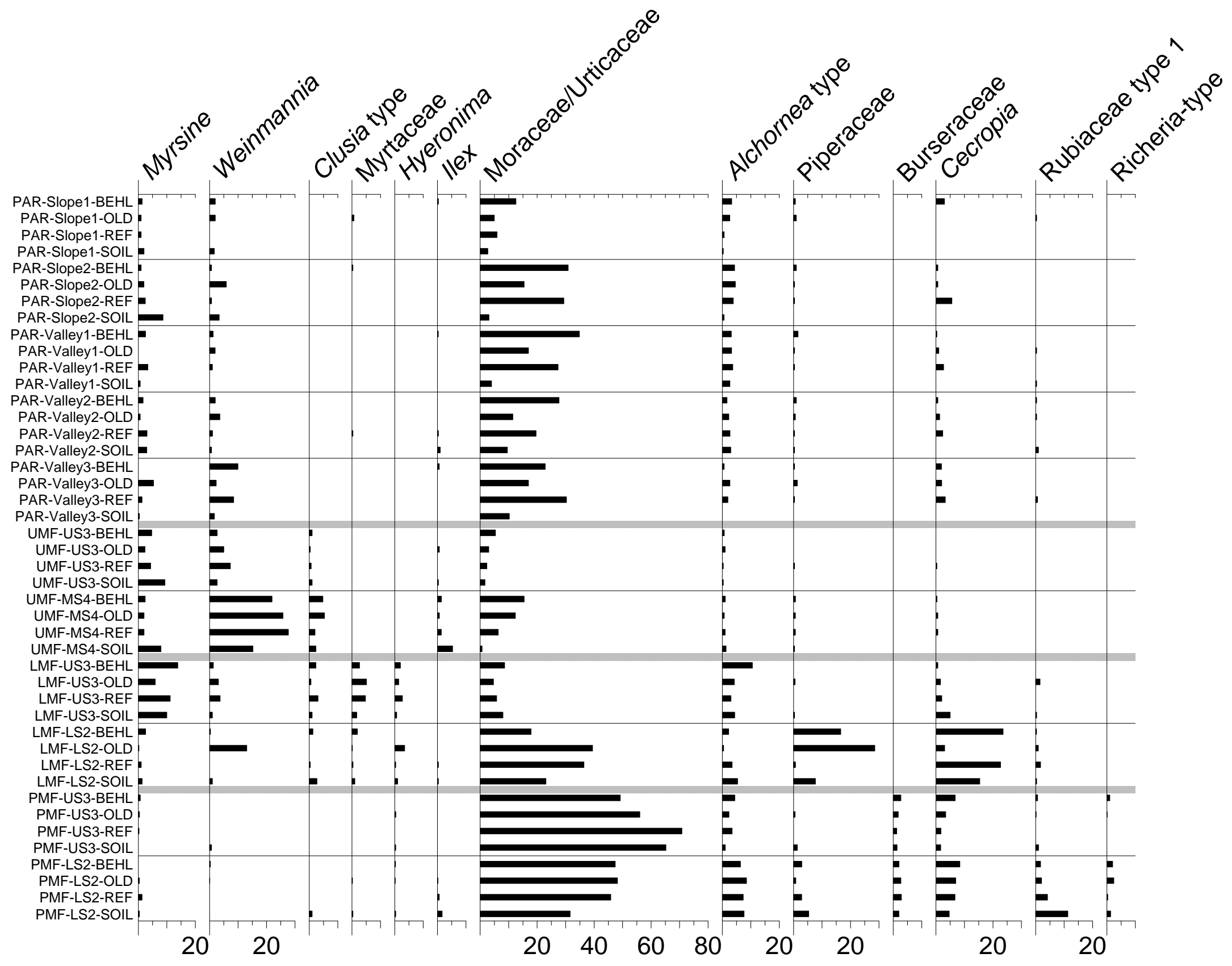




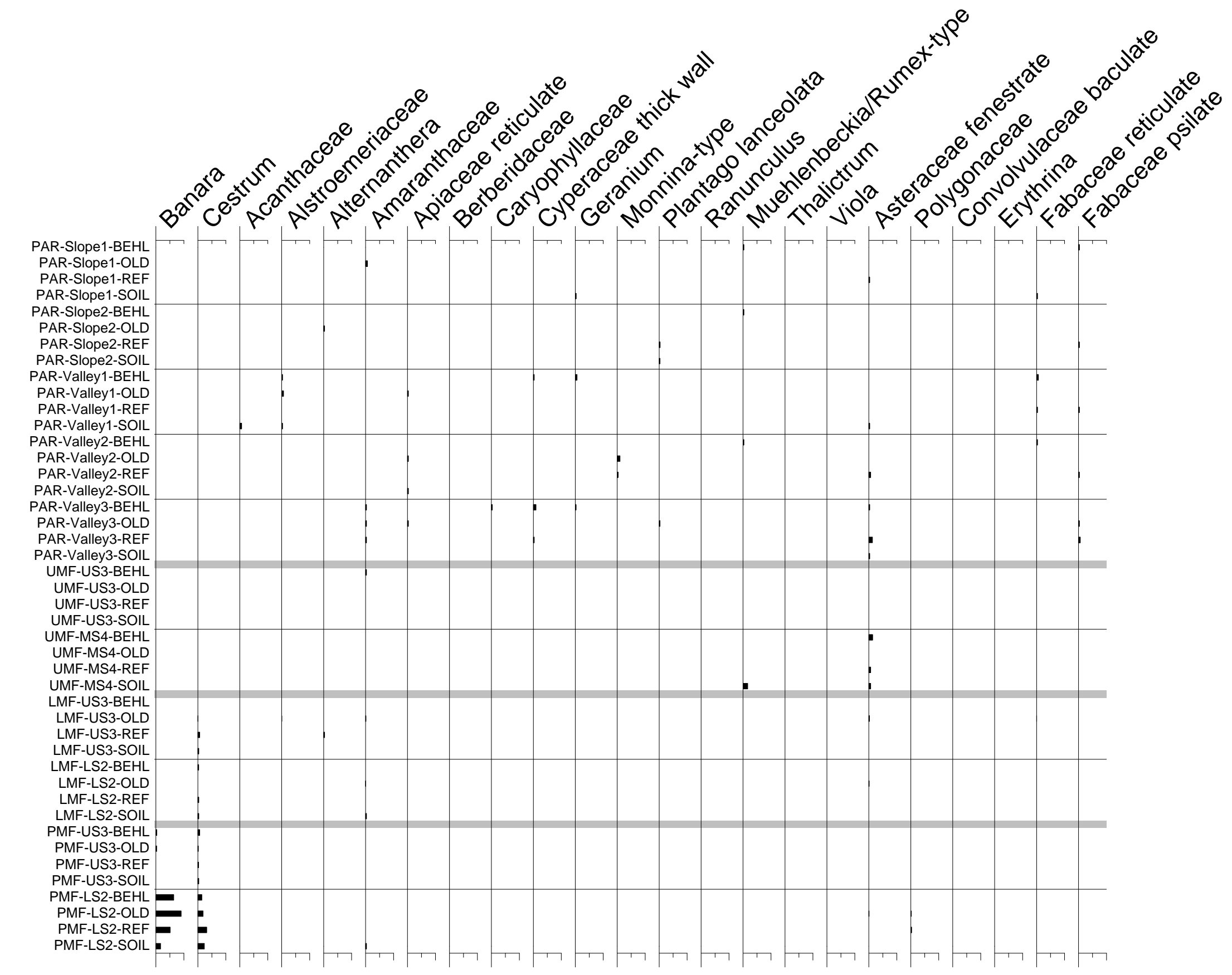




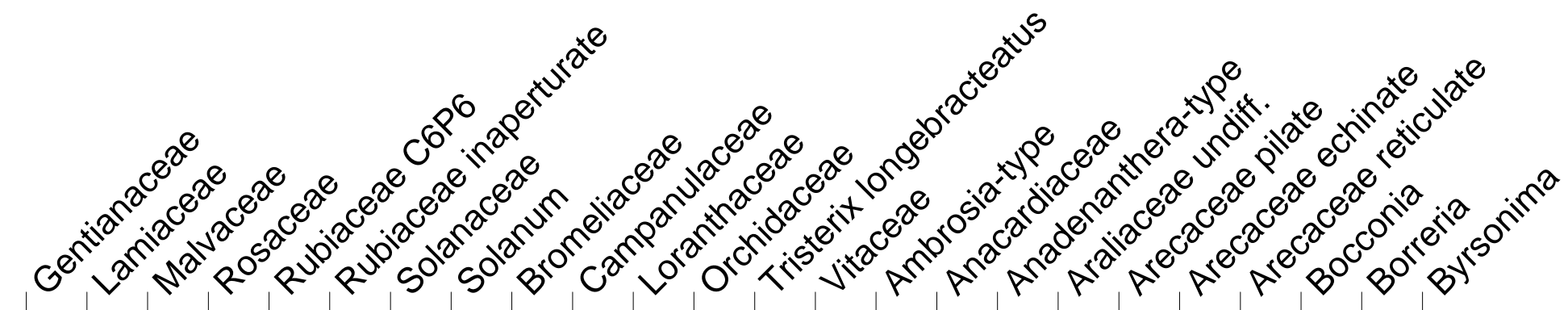

PAR-Slope1-BEHL PAR-Slope1-OLD PAR-Slope1-SOIL PAR-Slope2-BEHL PAR-Slope2-OLD PAR-Slope2-REF PAR-Slope2-SOIL PAR-Valley1-BEHL PAR-Valley1-OLD PAR-Valley1-REF PAR-Valley1-SOIL PAR-Valley2-BEHL PAR-Valley2-OLD PAR-Valley2-REF PAR-Valley2-SOIL PAR-Valley3-BEHL PAR-Valley3-OLD PAR-Valley3-REF

PAR-Valley3-SOIL UMF-US3-BEHL UMF-US3-OLD UMF-US3-REF

UMF-US3-SOIL UMF-MS4-BEHL UMF-MS4-REF UMF-MS4-SOIL LMF-US3-BEHL LMF-US3-OLD LMF-US3-REF LMF-US3-SOIL LMF-LS2-BEHL LMF-LS2-OLD LMF-LS2-REF MF-LS2-SOIL PMF-US3-BEHL PMF-US3-OLD PMF-US3-REF PMF-US3-SOIL

PMF-LS2-BEHL

PMF-LS2-OLD

PMF-LS2-REF

PMF-LS2-SOIL 

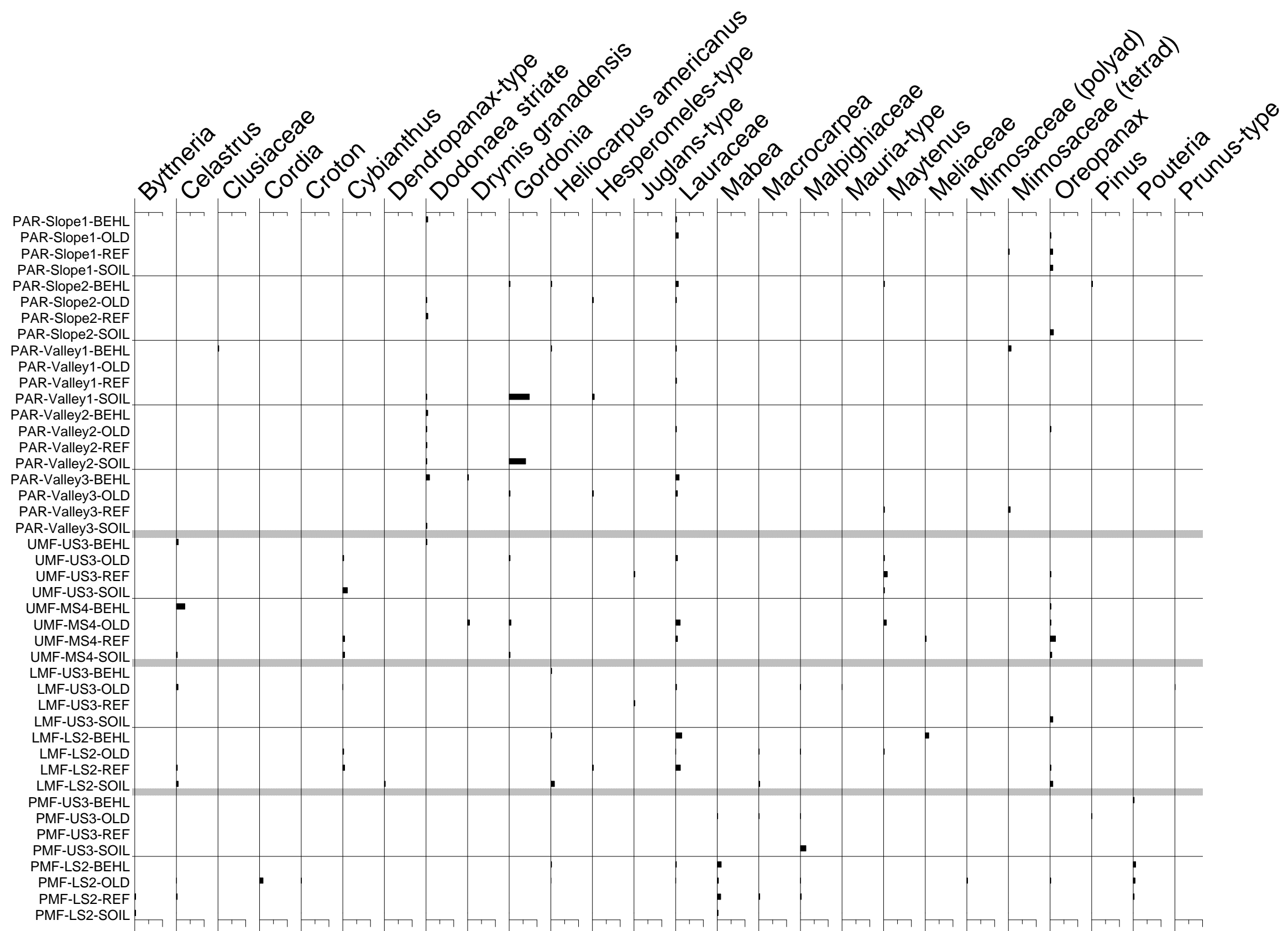


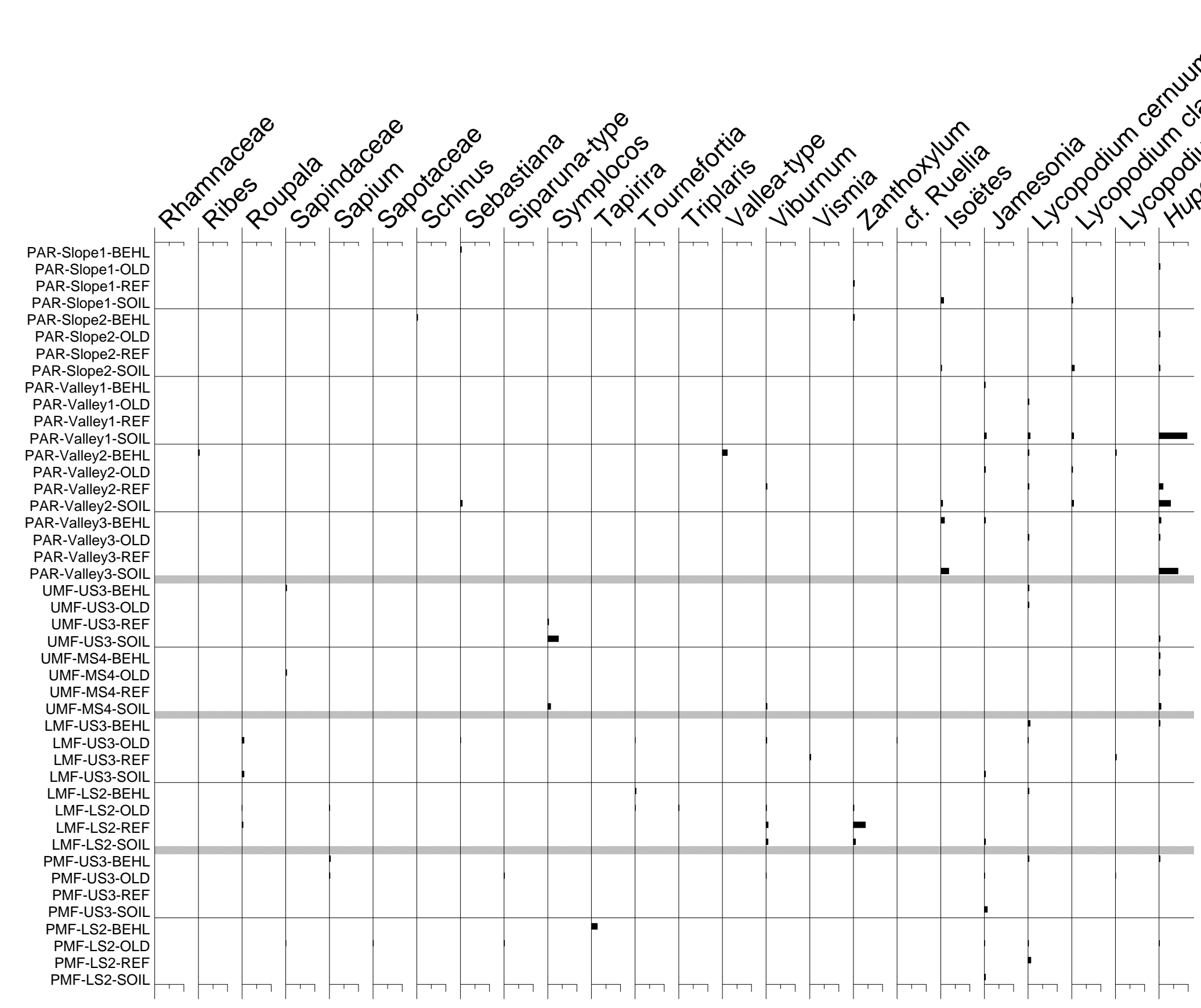




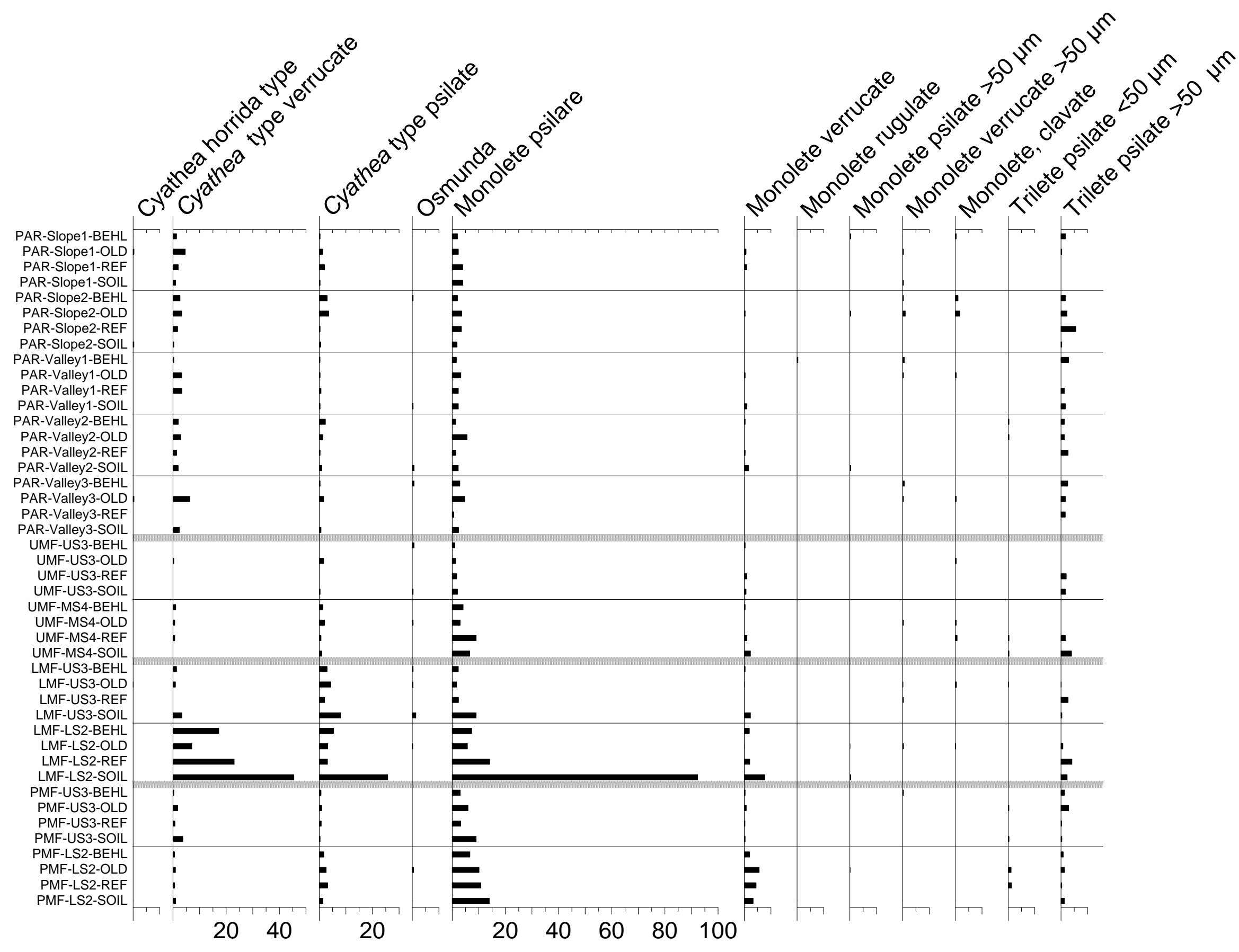




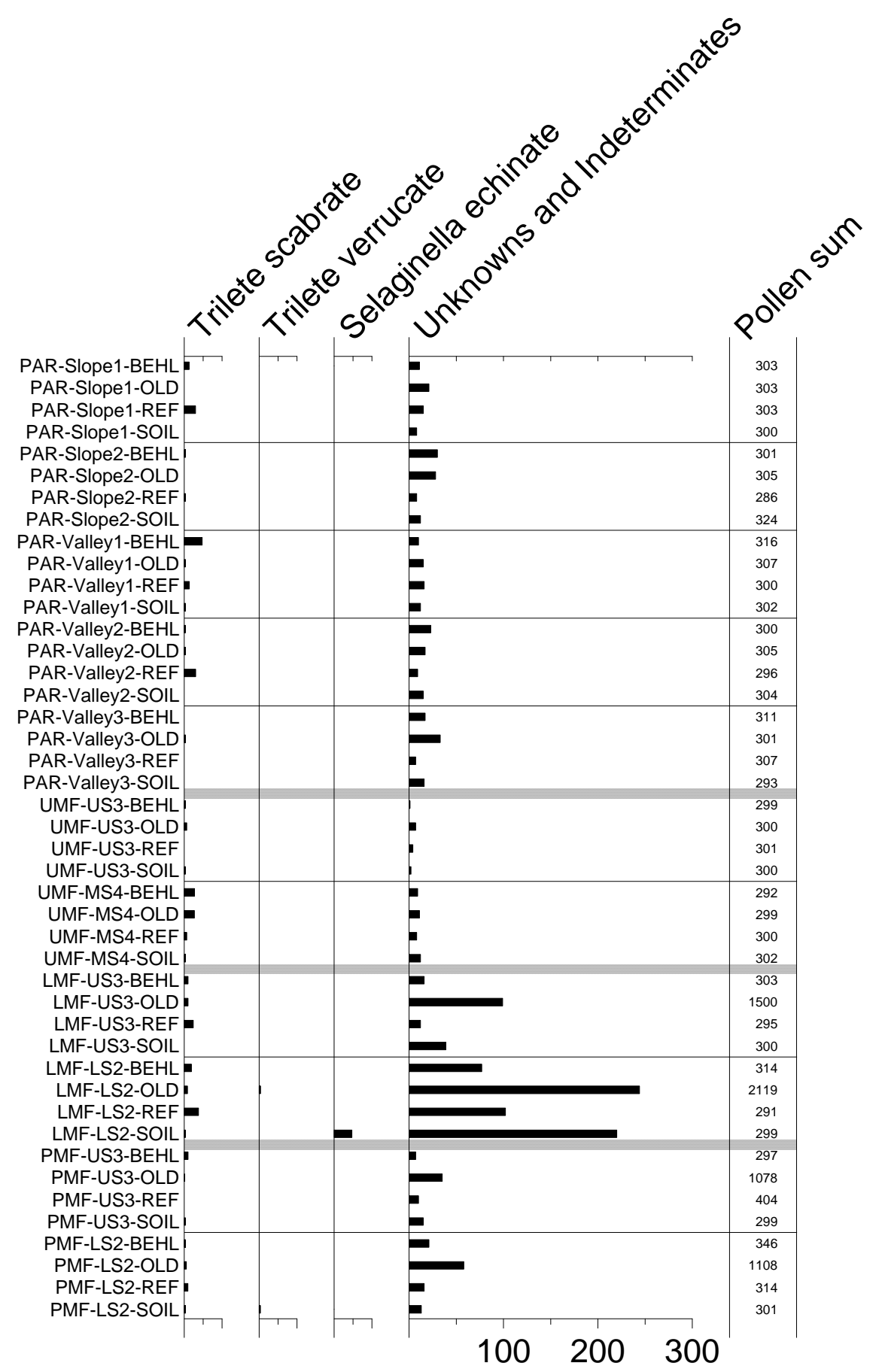

